

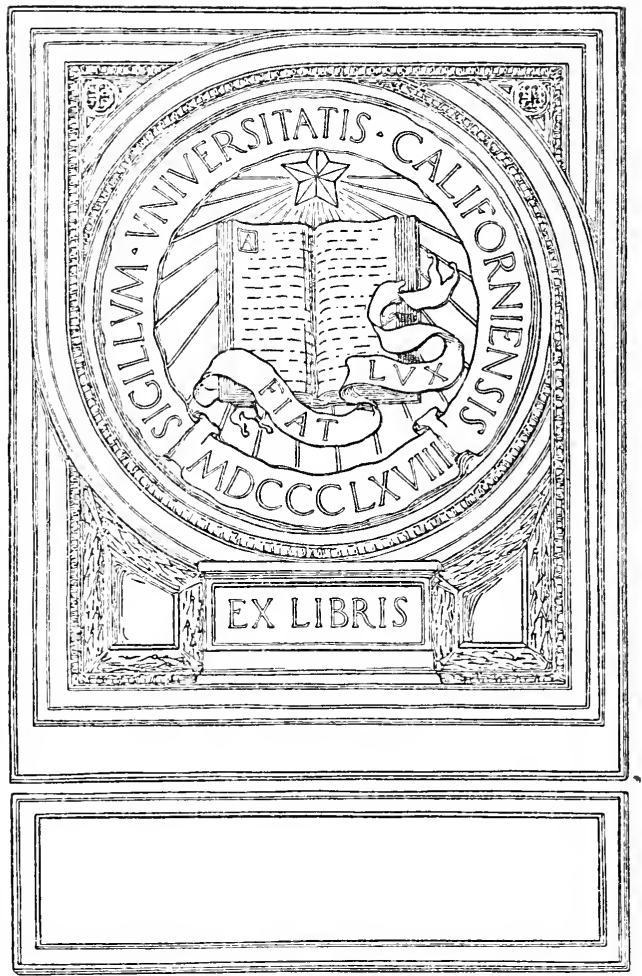

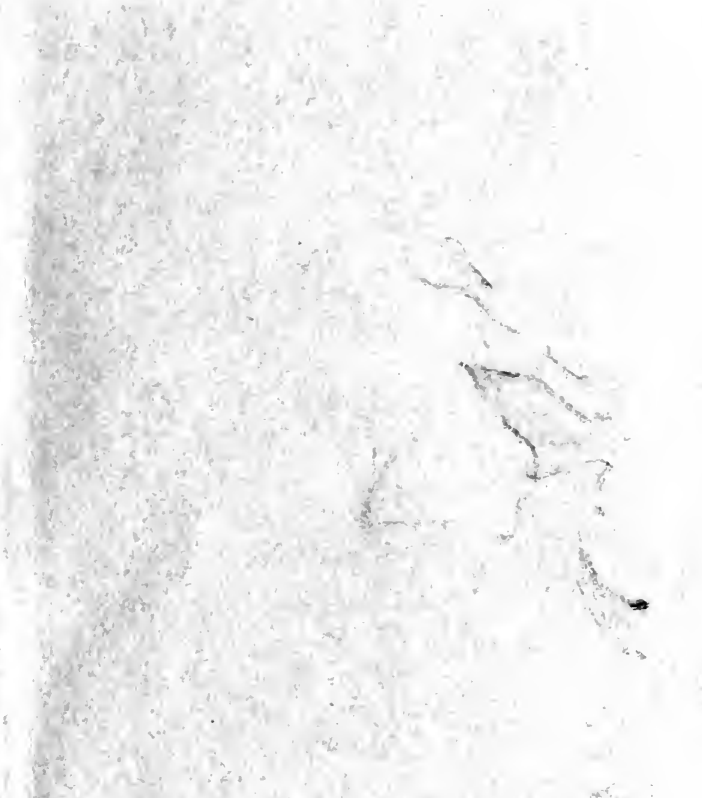

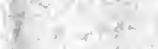

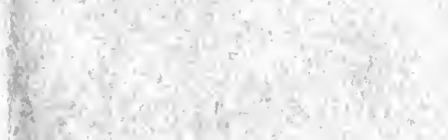

$\left\{\begin{array}{l}3 \\ 3\end{array}\right.$

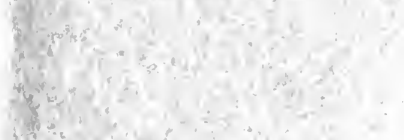

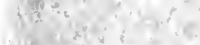

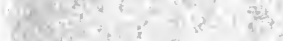

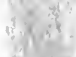

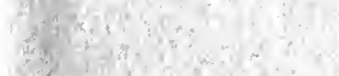

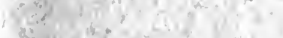

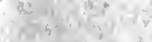

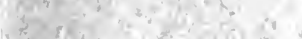

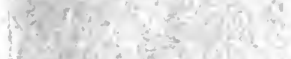

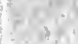








\section{HISPAN IC}

Notes and Monographs

ESSAYS, STUDIES, AND BRIEF BIOGRAPHIES ISSUED BY THE HISPANIC SOCIETY OF AMERICA

PENINSULAR SERIES 
$\because \because \because \because \vdots \vdots \vdots \vdots$

$\therefore: \vdots \because \vdots \vdots \because \div \div \div: \vdots \vdots$ 


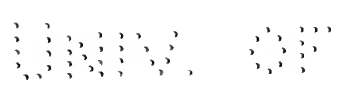

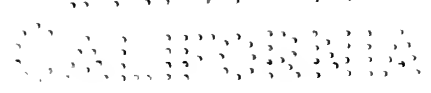




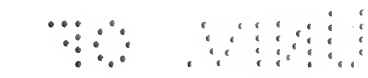

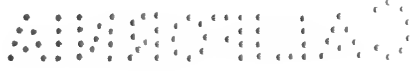

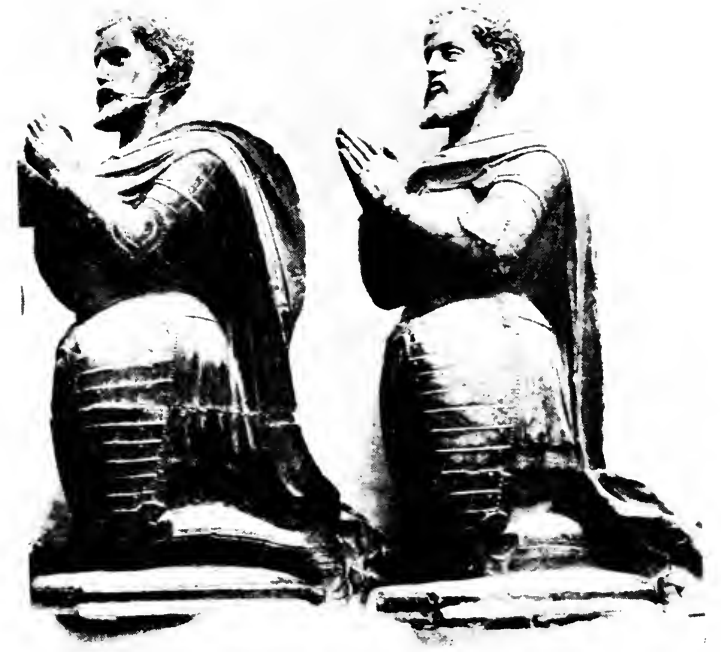

(iarcilatso de la Vega and his son of the same name San Pedro Mártir, Toledo 


\title{
GARCILASO DE LA VEGA
}

\author{
A Critical Study of His \\ LIFE AND WORKS
}

BY

\section{HAYWARD KENISTON}

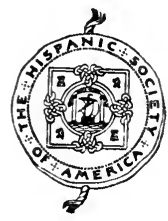

NEW YORK

HISPAXIC SOCIETY OF AMERICA 
COPYRIGHT, 1922

IXY

THE HISPANIC SOCIETY OF AMERICA

Cornell publications PRINTING Co.

ITHACA, N. Y. 


\begin{tabular}{|l|}
\hline P R E F A C E \\
\hline PREFACE \\
The present study is the outgrowth of \\
investigations begun in I9og in the prepara- \\
tion of a doctoral dissertation for Harvard \\
University. Since that thesis was accepted \\
in I I I, several years of study in Europe \\
and further investigations in this country \\
have so developed the theme that the pre- \\
sent volume, and a second volume, contain- \\
ing a critical text and bibliography of the \\
poet's works which is to appear shortly, \\
have little resemblance to the original \\
essay. \\
In this volume I have attempted first to \\
present the actual facts concerning the \\
poet's life. Disregarding the numerous ac- \\
counts which have no solid basis of informa- \\
tion, I have endeavored to reconstruct the \\
story of the man as he appears in original \\
documents. But I have not contented my- \\
self with recording specific references to \\
him. We could form but a scanty picture
\end{tabular}




\begin{tabular}{|l|l|}
\hline vi & \multicolumn{1}{|c|}{ GARCILASO DE LA VEGA } \\
\hline from the scattered comments of his con- \\
temporaries or the dry formulae of notarial \\
documents. Fortunately, however, we \\
know something of his whereabouts during \\
most of his life and it has been my aim to \\
trace his career by a study of other docu- \\
ments of the time and of such of his poems \\
as cast light on the events of his life. to \\
visualize him as a person. \\
In the study of his works. I have tried to \\
record the results of my own investigations \\
and my own impressions. without neglect- \\
ing the vast body of criticism which already \\
exists. It is true that I have not included \\
all the thousands of mentions of Garcilaso \\
which I have noted down; they would have \\
added to the bulk of the work rather than \\
to its interest, for most of the praise of his \\
verse is conventional. It has been nomy hope, \\
not merely to summarize our present \\
knowledge of his work but also to give an \\
honest and sympathetic estimate of its \\
value. \\
In the Appendices will be found two \\
documents of interest: the hitherto un- \\
H I S P A N I C N O T E S
\end{tabular}




\section{P REF A C E}

vii

published "Prueba de nobleza" of Garcilaso and the letter of Scipione Capece, from the rare edition of Donatus's Commentary on the Aenead, which has not before been republished. The List of Works consulted contains only those which are frequently referred to in the Notes.

I cannot fail to acknowledge here my indebtedness to those who have preceded me in the study of Garcilaso; it is far greater than the Notes can possibly reveal. I would also express my gratitude to the many friends in Spain, Italy, and America who have so generously aided me with their counsel.

$$
\text { H. K. }
$$

\section{A N D MONOGRAPH S}





\section{O N T E N T S}

LIFE

PAGE

Chapter I. Family Heritage . I

Chapter II. School Days . . $\quad$ I8

Chapter III. In the King's Service 42

Chapter IV. An Ill Fated Expedition . . 47

Chapter V. Knighthood and

Marriage . $\quad 5^{6}$

Chapter VI. A Courtier of the Emperor . . 69

Chapter VII. Isabel Freire. • 77

Chapter VIII. The Journey to Italy 85 Chapter IX. A Mission to France 97 Chapter X. Imperial Disfavor I03 Chapter XI. Exile in Naples . II7 Chapter XII. The Expedition to Tunis . . . I 29

Chapter XIII. The Last Campaign $\mathrm{I}_{42}$ Chapter XIV. The Tower of

$$
\text { Le Muy . . I53 }
$$

Chapter XV. The Chapel of the Rosary . . . 160

Chapter XVI. Personality . . I7I 
WORKS

Chapter I. Spanish Verses . I79

Chapter II. The Letters . . 265

Chapter III. The Latin Poems 270

Chapter IV. Versification . • 277

Chapter $\mathrm{V}$. Orthography, Vocab-

$$
\text { ulary, Grammar } 347
$$

Chapter VI. The Fortuna of Gar-

$$
\text { cilaso . . } 363
$$

Appendix A. Prueba de Nobleza $\quad+35$

Appendix B. Letter of, Scipione

Capece . . 438

List of Works Consulted . $\quad+39$

Notes 


\section{LIFE}



o 


\section{GARCILASO DE LA VEGA}

\section{CHAPTER I \\ FAMILY HERITAGE}

ON the northwestern slope of the sheer hill upon which Toledo is perched, a narrow passage, half staircase, half alley, once called the Cuesta de Garcilaso de la Vega but now known as the Cuesta de Santo Domingo el Antiguo, drops down from the Plazuela de Padilla toward the Tagus. For the most, the houses which keep eternal shadow on the ill-paved way are prim, conventual, but a few rods down the slope another alley, the Cobertizo de Santo Domingo el Antiguo, as steep and dirty as the first, throws into relief an old, ruined building upon the corner. It is a grim, massive structure, built in the style that Andrea Navagero, ambassador of Venice at the court of Charles V, remarked to be typical of the palaces of the Toledan nobility, four-square and unadorned, of rough stone with terra-cotta

\section{H I S P N I C NOTES}




\begin{tabular}{|c|c|}
\hline 2 & GARCILASO DE LA VEGA \\
\hline & $\begin{array}{l}\text { courses, with small, square windows. }{ }^{1} \\
\text { Above the broad doorway a white sign } \\
\text { shows its present use: "Ignacio Carrido, } \\
\text { Cerrajería", and within beneath a canvas } \\
\text { awning, for the roof and floors are gone, } \\
\text { the locksmith works in lonesome state. } \\
\text { From the threshhold there is a glimpse, } \\
\text { over the jagged line of roof-tiles, of the } \\
\text { green Vega in the distance, where } \\
\text { con agradable mansedumbre } \\
\text { el Tajo va siguiendo su jornada, } \\
\text { y regando los campos y arboledas } \\
\text { con artificio de las altas ruedas. } \\
\text { Set in the wall of the house is a white } \\
\text { marble tablet which bears this inscription: } \\
\text { "AQUI ESTUVO LA CASA SOLARIEGA DONDE } \\
\text { NACIO EN I5C3 EL INSIGNE VATE - PRINCIPE } \\
\text { DE LOS POETAS LIRICOS CASTELLANOS - y } \\
\text { VARON ESFORZADO EN EMPRESAS MILITARES } \\
\text { - GARCI-LASSO DE LA VEGA. LA IMPERIAL } \\
\text { CIUDAD DEDICA ESTE HUMILDE RECUERDO } \\
\text { A LA PERDURABLE MEMORIA DE TAN ES- } \\
\text { CLARECIDO HIJO. I } 7 \text { DE AGOSTO DE I } 900 . \text { " } \\
\text { In this SEignorial hOuse, then, was born }\end{array}$ \\
\hline & H I P A N I N N T E S \\
\hline
\end{tabular}




\section{LIFE A N D W ORK S}

the poet and soldier of Toledo, Garcilaso de la Vega. But the date of his birth is by no means certain. Fernández de Navarrete in his Life of Garcilaso assigned it to the year $1503^{1}$ and since the publication of his work (I850), that date has been generally accepted. He gives however no authority for his statement and inasmuch as no parochial records for the period exist, we must seek for other evidences. The first of the biographers of Garcilaso, Fernando de Herrera, was not a contemporary of the poet, but he did know personally his son-in-law, Antonio Puertocarrero, and his statements are therefore deserving of credit. In closing his account of the death of Garcilaso in ${ }_{1536}$ he states that he died at the age of thirtyfour, ${ }^{2}$ which would place his birth late in I5OI or in $\mathbf{I}_{502}$. He also tells us that he was married "soon after he was twentyfour or a little older" ("entrando en edad de 24 años o poco mas"). ${ }^{3}$ But we now know that he was married in ${ }^{5} 525,{ }^{4}$ which would establish $\mathrm{I} 5 \mathrm{OI}$ as the year of his

\section{A N D MONOGRAPHS}




\begin{tabular}{|c|c|}
\hline 4 & GARCILASO DE LA VEGA \\
\hline & $\begin{array}{l}\text { birth. The only other evidence which } \\
\text { bears upon the point is the statement of } \\
\text { Pero Abrera, the only witness called to } \\
\text { testify to Garcilaso's nobility during the } \\
\text { formal examination, which always pre- } \\
\text { ceded admission to the Order of Santiago, } \\
\text { on September II, I } 523 \text {, that he was } \\
\text { "about twenty-five years old" ("sera de } \\
\text { hedad de veynte e cinco anos, poco mas o } \\
\text { menos"). Unfortunately this statement, } \\
\text { which would place his birth in I } 498 \text {, can- } \\
\text { not be accepted as necessarily accurate. } \\
\text { For the Spaniard of the early sixteenth } \\
\text { century often had as hazy an idea of his } \\
\text { age as the negro of slavery days, and even } \\
\text { the Grand Duke of Alba, who was cer- } \\
\text { tainly born in I507 or I } 508 \text {, glibly testified } \\
\text { in I } 543 \text { that he "might be forty-three } \\
\text { years old,"' and Garcilaso's wife, Elena } \\
\text { de Zúniga, revealed an uncertainty as to } \\
\text { the age of her children, less understand- } \\
\text { able in a mother than in a father. }{ }^{3} \text { The } \\
\text { only value of Abrera's deposition is there- } \\
\text { fore that it makes it probable that Gar- } \\
\text { cilaso was born before, rather than after, }\end{array}$ \\
\hline & H I S A N I C NOTES \\
\hline
\end{tabular}




\section{LIFE A N W ORKS}

I503. We shall not be far from the truth, if we say that Garcilaso was born in I $501 .^{1}$

Concerning his forbears we are fortunately better informed and a brief glance at the long line of illustrious ancestors whose blood was in his veins is interesting, as rendering intelligible certain characteristics strikingly evidenced in him. ${ }^{2}$ The original seat of the family de la Vega was at Torrelavega in the Asturias, in a plain on the banks of the little river Besaya close to the sea. The first member of the family of whom we have certain knowledge is the Garcias Lasso, or Garci-Laso de la Vega, mentioned by Fernández de Oviedo in his manuscript Batallas $y$ quincuagenas as Merino Mayor de Castilla in the reign of Fernando IV. ${ }^{3}$ In the struggle for the regency of Castile during the minority of Alfonso XI which followed the death of Fernando IV, Garcilaso supported the party of the Infante Don Pedro and on the latter's death at Granada in 1319 , he assumed the guardianship of

\section{A N D M O N O G A P H S}




\begin{tabular}{|l|l|}
\hline 6 & $\begin{array}{l}\text { GARCILASO DE LA VEGA } \\
\text { his posthumous daughter and his place in } \\
\text { the control of the kingdom. When Alfonso } \\
\text { XI was given the reins of government at } \\
\text { the age of fourteen in I325, Garcilaso was } \\
\text { all-powerful among his advisors and was } \\
\text { named Chancellor of the realm. But the } \\
\text { ruthlessness with which he had suppressed } \\
\text { his enemies bore its fruit; he was mur- } \\
\text { dered on March 2, I328 while at mass in } \\
\text { the convent of San Francisco in Soria, } \\
\text { whither he had gone to negociate with } \\
\text { certain rebels against the king. His heir, } \\
\text { Garcilaso de la Vega, was still a lad at } \\
\text { the time of his father's death, but he } \\
\text { soon distinguished himself in the service } \\
\text { of the king and during the siege of Gibral- } \\
\text { tar in I334 he bore a brave part in the } \\
\text { rescue of the Spanish knights who had } \\
\text { been cut off on La Isla. With his brother, } \\
\text { Gonzalo Ruiz de la Vega, he was the } \\
\text { first to cross the Salado on that memor- } \\
\text { able day (October 30, I340) when the } \\
\text { forces of Castile and Portugal defeated } \\
\text { the Moors. Named Adelantado Mayor } \\
\text { de Castilla, Garcilaso was one of the first }\end{array}$ \\
\hline H I S P A N I C N O T E S \\
\hline and
\end{tabular}




\section{LIFE A N D W ORK}

of the nobles to feel the heavy hand of Pedro el Cruel after his accession to the throne in 1350 . He was murdered in cowardly fashion in the palace in Burgos in I35 I and his body thrown from the window to the square below. His son, once more named Garcilaso de la Vega, was rescued at the time by some of the servants and carried off to his estates in Asturias. From his marriage with Doña Mencía Cisneros, ${ }^{1}$ he had but one child, a daughter, Doña Leonor de la Vega.

The male line of the family thus became extinct, but Dona Leonor became the second wife of Diego Hurtado de Mendoza, Almirante under Enrique III, and the house of La Vega was thereby incorporated with that of Mendoza, which assumed the arms of the family of La Vega with their devise "Ave Maria gratia plena." Don Diego and Doña Leonor had three children. The eldest and heir to the estates was the celebrated Marquis of Santillana, Iñigo López de Mendoza, the chief literary figure of the fifteenth centu-

\section{A N D MONOGRAPH S}




\begin{tabular}{|c|c|}
\hline 8 & GARCILASO DE LA VEGA \\
\hline & $\begin{array}{l}\text { ry; the youngest was Dona Elvira Laso } \\
\text { de la Vega. This daughter married } \\
\text { Gómez Suárez de Figueroa, chatelain of } \\
\text { Badajoz. Of their children, the eldest } \\
\text { was Lorenzo Suárez de Figueroa, first } \\
\text { Count of Feria; the second was Pero } \\
\text { Suárez de Figueroa; the third was Gar- } \\
\text { cilaso de la Vega. Pero Suárez married } \\
\text { Doña Blanca Sotomayor }{ }^{1} \text { and their second } \\
\text { son was given the name of Garcilaso } \\
\text { de la Vega, according to the common } \\
\text { Spanish custom of choosing a name from } \\
\text { the maternal line for the younger sons. } \\
\text { This Garcilaso, the father of the poet, } \\
\text { was born in Badajoz. }{ }^{2} \text { He early entered } \\
\text { the service of Ferdinand and Isabella and } \\
\text { as their maestresala fought in the War of } \\
\text { the Succession against King Alfonso of } \\
\text { Portugal. For this he was rewarded in } \\
\text { I } 479 \text { with the grant of all the tolls paid } \\
\text { by the cattlemen on the sheep as they } \\
\text { passed through Badajoz on their annual } \\
\text { migration to the warm pastures of Ex- } \\
\text { tremadura. Two years later, he was } \\
\text { named a contino, or member of the per- }\end{array}$ \\
\hline & H ISPANIC NOTES \\
\hline
\end{tabular}




\section{LIFE AND WORKS}

sonal guard of the King and Queen. During the War of Granada he bore a valiant part and early in the siege of Velezmálaga

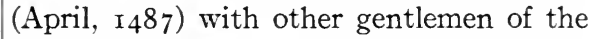
Court helped to save King Ferdinand's life. Although wounded in the capture of the suburbs of the town, he was able to serve in the siege of Málaga during the summer, where he acted as a captain. On the capture of the town of Vera in the following year (June ro), Garcilaso was made alcaide, or chatelain, but the forays of the Moorish chief, El Zagal, soon made it necessary for the sovereigns to dispatch him with reinforcements to protect the frontier. In the spring of 1489 Ferdinand took the field in force to besiege the town of Baza and Garcilaso is named as the captain of forty lances in the great throng of Spanish nobles who fought under the banner of the king. Baza finally capitulated on December 4 and the King and Queen, having accepted the surrender of Almería, started for that city three days later. They were met outside the town

\section{A N D MONOGRAPHS}




\begin{tabular}{|l|l|}
\hline 10 & $\begin{array}{l}\text { GARCILASO DE LA VEGA } \\
\text { by El Zagal, who came to offer them his } \\
\text { possessions. Having received the Moorish } \\
\text { prince with courtesy, they escorted him to } \\
\text { the royal tent and served him a sumptu- } \\
\text { ous repast. Among the Spanish nobles } \\
\text { who served at this meal, Garcilaso is } \\
\text { named as the cupbearer to El Zagal. } \\
\text { During the next four years there is no } \\
\text { mention of Garcilaso in the chronicles of } \\
\text { the times. But curiously enough it is } \\
\text { precisely to these years that belongs a } \\
\text { tradition concerning him which gained } \\
\text { wide currency in the following centuries. } \\
\text { Briefly, the legend relates how Hernán } \\
\text { Pérez del Pulgar, "El de las hazanas," } \\
\text { stole into Granada one night during the } \\
\text { siege and with his dagger fastened upon } \\
\text { the door of the mosque a parchment bear- } \\
\text { ing the words, "Ave Maria gratia plena." } \\
\text { On the discovery of this insult a Moorish } \\
\text { knight, Tarfe, tore down the parchment, } \\
\text { tied it to his horse's tail, and riding forth } \\
\text { to the Spanish camp of Santa Fe, chal- } \\
\text { lenged the Christians to send forth a } \\
\text { champion, or several of them, to defend }\end{array}$ \\
\hline H I S P A N I C N O T E S \\
\hline then
\end{tabular} \mid




\section{LIFE AND WORKS}

the honor of their Lady. Garcilaso begged the king's permission to undertake the exploit but was denied the privilege because of his youth. In spite of this refusal he slipped out of the camp, attacked and killed the arrogant Moor and presently, to the surprise of the Court, rode proudly into Santa Fe, bearing Tarfe's dripping head upon his lance and wearing the parchment upon his breast. As a reward he was granted the right to assume the words upon the parchment as his devise and also the title of "de la Vega,"

porque en la Vega hiciera campo con aquel pagano. ${ }^{1}$

The first version of this story to appear in print is to be found in the Romancero historiado of Lucas Rodríguez (I 579) and further variants soon followed in the Romancero $y$ tragedias of Gabriel Lobo Laso de la Vega $\left(\mathrm{r}_{587}\right)$, the Historia de los vandos de los Zegries y Abencerrages of Ginés Pérez de Hita (1595) and the Romancero general ( $\mathrm{r} 600$ ). But the story

\section{A N D MONOGRAPHS}




\begin{tabular}{|c|c|}
\hline 12 & GARCILASO DE LA VEGA \\
\hline & $\begin{array}{l}\text { must have been current before } \mathrm{I} 579 \text {, for } \\
\text { it is the theme of one of the earliest of } \\
\text { Lope de Vega's plays, Los hechos de } \\
\text { Garcilaso de la Vega y Moro Tarfe, the } \\
\text { only play of his which has survived in } \\
\text { four acts, and Lope himself declares that } \\
\text { he wrote his first play at the age of twelve, } \\
\text { that is, in I574. In fact it seems probable } \\
\text { that the tradition goes back to the fifteenth } \\
\text { century to another Garcilaso de la Vega, } \\
\text { the third son of Gómez Suárez de Figueroa } \\
\text { and uncle of the contino of the Catholic } \\
\text { Monarchs, who was Comendador of Mon- } \\
\text { tizón under Enrique IV. For Alonso de } \\
\text { Palencia in his Crónica de Enrique I } V^{3} \\
\text { tells how this Garcilaso, challenged to } \\
\text { single combat by a Moor in the Vega of } \\
\text { Málaga (I } 456 \text { ), slew him and carried off } \\
\text { his horse and other trophies and how, two } \\
\text { years later, he was killed by a poisoned } \\
\text { arrow near Baza, an event which was } \\
\text { lamented by Gómez Manrique in his poem, } \\
\text { La defunzion del noble cavallero G. }{ }^{a} \text { Laso } \\
\text { de la Vega. It is not strange that the } \\
\text { exploits of this knight were confused with }\end{array}$ \\
\hline & H I S A N IC NOTES \\
\hline
\end{tabular}




\section{LIFE A N D WORKS}

those of his nephew, who, as we shall see, later gained distinction under Ferdinand and Isabella, nor is it surprising that genealogists of the sixteenth century attributed this exploit to the Garcilaso who fought at the battle of the Salado in 1340 and thus accounted for the title and the arms of the family as well as of the family of the Mendozas. ${ }^{1}$ It is one of the numerous poetical traditions which has been transferred to another member of the family whose distinction attracted to him all the records of deeds of valor in the family, and which at the same time seeks to explain the origin of his titles and arms. Its chief historical interest is that it reveals that its hero was deemed capable of performing the exploit which it relates.

To return to the life of Garcilaso, the courtier of Ferdinand and Isabella, we find him named as ambassador to the Pope, Alexander VI, on March I, I494. During the next five years he was a vigourous, if undiplomatic, representative of Spain at Rome during the troublous times

\section{A N D MONOGR A P H S}




\begin{tabular}{|l|l|}
\hline 14 & $\begin{array}{l}\text { GARCILASO DE LA VEGA } \\
\text { of the invasion of Italy by Charles VIII } \\
\text { of France. His affection for arms had } \\
\text { not diminished, however, and in March, } \\
\text { I497 he bore a leading part under the } \\
\text { Grand Captain, Gonzalo de Córdoba, in } \\
\text { the capture of Ostia. His plain speech to } \\
\text { Alexander VI finally made him unpopular } \\
\text { with that pontiff and he left Rome on } \\
\text { July I, I499, returning to Spain in the } \\
\text { company of Queen Juana of Naples, sister } \\
\text { of Ferdinand V.1 At the Court he soon } \\
\text { found himself high in the councils of the } \\
\text { King and Queen and honors and rewards } \\
\text { were showered upon him. In his absence } \\
\text { he had been appointed governor of Jerez } \\
\text { de la Frontera and he now received a } \\
\text { similar office at Vera and Gibraltar. In } \\
\text { I502 he was made a member ot the Privy } \\
\text { Council and upon the death of Gutierre } \\
\text { de Cárdenas on January } 2 \mathrm{I} \text {, I 503 was ap- } \\
\text { pointed in his stead as Comendador Mayor } \\
\text { de León. At the Cortes held in Toro in } \\
\text { January, two years later, Garcilaso acted } \\
\text { as its president. The beloved Queen } \\
\text { Isabella had died in the preceding year } \\
\text { - H I S P A N I C N O T E S }\end{array}$ \\
\hline
\end{tabular}




\section{LIFE AND WORKS}

and when her daughter Juana with the consort, Philip I, landed at Corunna on April 28, I 506, the great majority of the Castilian nobles hastened to pay to them the tribute of their loyalty. When Ferdinand V met Philip near Puebla de Senebria on June 20 , Garcilaso was among the knights of Castile in the latter's suite who appeared upon the field with a suit of armor beneath his cloak and it is related that as Ferdinand greeted him and slapped his shoulder, he said, like Caesar to Brutus, in a voice filled with disappointment, "You, too, García? (iY tú, García, también? )",

For his devotion to Philip he was rewarded during the summer by an appointment as tutor and chief chamberlain to the Infante Fernando, second son of Philip and Juana and later king of Bohemia and emperor of Germany, who was then three years old. Philip's death on September $25^{\text {th }}$ of the same year deprived him of his protector and when Ferdinand returned as regent he found that his de-

\section{A N D MONOGRAPHS}




\begin{tabular}{|c|c|}
\hline 16 & GARCILASO DE LA VEGA \\
\hline & $\begin{array}{l}\text { sertion of his cause had cost him his } \\
\text { favor. The latter years of his life were } \\
\text { uneventful; he died in the monastery of } \\
\text { San Juan at Burgos, on September 8, } \\
\text { I5I } .^{\text {. }} \\
\text { Garcilaso de la Vega had married Doña } \\
\text { Sancha de Guzmán, whose lineage was as } \\
\text { illustrious as his own, for the Guzmanes } \\
\text { traced their ancestry to the earliest days } \\
\text { of the County of Castile and boasted } \\
\text { three queens from their stock. Her } \\
\text { grandfather was Fernán Pérez de Guzmán, } \\
\text { "a soldier and a man of letters belonging } \\
\text { to the high aristocracy of the country, and } \\
\text { occupied in its affairs," famous as the } \\
\text { author of the Generaciones } y \text { semblanzas. } \\
\text { Through the death of her brother, Pedro } \\
\text { Suárez de Guzmán, she had inherited the } \\
\text { estates of Batres and in I } 502 \text { she and her } \\
\text { husband acquired the estate of Cuerva. } \\
\text { Later the estates of Arcos, established by } \\
\text { Garcilaso's parents, were inherited and } \\
\text { added to the patrimony. }{ }^{3} \\
\text { Such are the antecedents of the man } \\
\text { whose life we would study. They are }\end{array}$ \\
\hline & H I P A N I C NOTES \\
\hline
\end{tabular}




\section{LIFEA A D ORKS}

strong men, brave fighters for their kings, accomplished courtiers, men who have risen and who have fallen with the intricacy of royal whim, and yet men of letters, who have cherished a regard for the masters of the past and have striven to emulate their example. Their spirit is clearly reflected in the soldier and poet of Charles V.

\section{A N D MONOGRAPHS}




\begin{tabular}{|c|c|}
\hline 18 & GARCILASO DE LA VEGA \\
\hline & $\begin{array}{l}\text { CHAPTER II } \\
\text { SCHOOL DAYS } \\
\text { Garcilaso de la Vega, born as we have } \\
\text { seen in I } 50 \text { I or I } 502 \text {, was the second of } \\
\text { seven children. } .^{1} \text { The heir to the family } \\
\text { estates, Pedro Laso de la Vega, who was } \\
\text { destined to become notorious as one of } \\
\text { the leaders of the Junta of the Comunidad } \\
\text { in Toledo in I } 520 \text { and I } 52 \text {, was apparently } \\
\text { much older than he, if we may judge by } \\
\text { the position of leadership which he had } \\
\text { won by I } 520 \text {, and was probably born } \\
\text { before } 1495 \text {. His youngest brother, Fer- } \\
\text { nando de Guzmán, was killed during the } \\
\text { siege of Naples by Lautrec in I } 5^{27} \text {, at the } \\
\text { age of twenty;" the older of his two sisters, } \\
\text { Doña Leonor de la Vega, married Luis } \\
\text { Fernández Puertocarrero, Count of Palma. } \\
\text { Concerning the boyhood of Garcilaso the } \\
\text { only information which we possess is the } \\
\text { statement of Herrera that "he was brought }\end{array}$ \\
\hline & H I S A N I C NOTES \\
\hline
\end{tabular}




\section{IF E A N D W ORK S}

up in Toledo until he was old enough to serve the Emperor and follow his Court."' Navarrete doubts the accuracy of this statement, without alleging any reasons, and is inclined to the belief that he was educated at the Court, perhaps by Peter Martyr. ${ }^{2}$ There seems to be no valid reason for questioning the authority of Herrera, particularly because Garcilaso was a younger son of his house. What was the sort of education which he received in Toledo? What, in general, was the education of the youth of the Spanish nobility in the first years of the sixteenth century? There is no circumstantial account of educational methods for precisely these years, but we may form some idea of the matter by studying the periods which preceded and which followed them.

Queen Isabella had manifested a most lively interest in the education of her children and especially in that of the heir to the throne, Don Juan. For him she devised an elaborate system of training of which Fernández de Oviedo has left us a

\section{A N D MONOGRAP H S}




\begin{tabular}{|l|l|}
\hline 20 & $\begin{array}{l}\text { GARCILASO DE LA VEGA } \\
\text { detailed account in his Libro de la Cámara } \\
\text { Real del Principe Don Juan. } .^{\text {The Queen }} \\
\text { instituted for her son's education a sort } \\
\text { of miniature college, consisting of five } \\
\text { masters, chosen from the high nobility, } \\
\text { and five students, sons of the principal } \\
\text { families of the realm. His instruction in } \\
\text { Latin and the humanities was intrusted } \\
\text { to Fray Diego de Deza and in the library } \\
\text { of Isabella are noted a number of copy- } \\
\text { books which the young prince had used } \\
\text { for his compositions in Latin. Besides his } \\
\text { formal studies he was taught to fence with } \\
\text { the sword, to hunt, and above all, to sing } \\
\text { and to play upon various instruments, } \\
\text { organ, the clavichord, the viola, and the } \\
\text { guitar. That these remained the principal } \\
\text { fields of instruction in the following reigns } \\
\text { is clear from the Relazione of the Venetian } \\
\text { Ambassador at the Court of Charles V, } \\
\text { Marino Cavalli, who briefly describes the } \\
\text { training of the pages at the Imperial } \\
\text { court, sons of counts and nobles. "They } \\
\text { have their masters," he says, "to teach } \\
\text { them to dance, to fence, to ride and wheel }\end{array}$ \\
\hline H I S P A N I C N O T E S \\
\hline
\end{tabular}




\section{I F E A N D W ORK S}

on horseback, and a little book-learning (un poco di lettere)." 1

If these were the arts which kings felt worth inculcating in their princes and courtiers, we may be sure that all of the nobility trained their sons in a similar fashion to fit them for service one day at the Court. There can be no doubt that Garcilaso too was trained in these accomplishments of the perfect gentleman. The only contemporary reference to his personal qualities, that of Fernández de Oviedo, was that he was "an excellent player on the harp and a thorough gentleman (gentil musico de harpa e buen cavallero)," and to give weight to his opinion Oviedo adds, "and I saw him play several times.", Herrera as well mentions his accomplishments saying, "He was very skilled in music, in the viola and the harp, and of great experience in the training of a soldier (Fue mui diestro en la musica, $i$ en la vihuela $i$ arpa i exercitadissimo en la disciplina militar)., ${ }_{3}$ But Garcilaso was more than a courtly gentleman; he was also a scholar and in

\section{A N D MONOGRAPH S}




\begin{tabular}{|c|c|}
\hline 22 & GARCILASO DE LA VEGA \\
\hline & $\begin{array}{l}\text { his youth he must have received far more } \\
\text { than the smattering of letters provided for } \\
\text { Prince Juan or the pages of Charles V. } \\
\text { Let us see what this instruction must have } \\
\text { been. } \\
\text { The wave of humanistic studies which } \\
\text { swept Italy in the first half of the fifteenth } \\
\text { century was long in reaching Spain. }{ }^{1} \text { An- } \\
\text { tonio de Lebrija, the father of Spanish } \\
\text { humanism, returned from Italy in I } 473 \\
\text { to teach Latin in the University of Seville; } \\
\text { in I } 484 \text { Lucio Marineo Siculo came to } \\
\text { Salamanca from Sicily at the instigation } \\
\text { of the Almirante, Fadrique Enríquez; and } \\
\text { three years later the Count of Tendilla, on } \\
\text { his return from his embassy in Rome, } \\
\text { brought with him Peter Martyr of An- } \\
\text { ghiera. Although Spain was still engrossed } \\
\text { in its struggle to drive out the Moors, the } \\
\text { Queen's interest in the promotion of learn- } \\
\text { ing was already beginning to have its effect. } \\
\text { In a letter to the Count of Tendilla Peter } \\
\text { Martyr has left a humorous description } \\
\text { of his first lecture on Juvenal at Sala- } \\
\text { manca in September, I } 483 .^{2} \text { It was a }\end{array}$ \\
\hline & H I S A N IC NOTES \\
\hline
\end{tabular}




\section{IFE A N D WORK S}

Tuesday, the mid-week holiday, and as a result the whole University thronged to the lecture-hall. When Peter Martyr arrived, the throng was so dense that it was impossible for the beadles, in spite of shouts, threats, even of vigorous blows with lances and staffs, to open a passageway for the professor. And so it was necessary to lift him up and pass him over the heads of the multitude to the platform. Hats innumerable were lost, and cloaks torn in the press. One of the beadles lost his crimson robe and later tried to make Martyr responsible for damages. When the lecture was finished he was escorted to his lodgings like an Olympic victor. With all its playful exaggeration the letter is a document of the greatest significance, for it reveals that already learning was held in respect and was sought for with eagerness.

No sooner was Granada captured early in 1492 than the Queen turned her attention to encouraging even more the growing interest in classical studies. At her

\section{A N D MONOGRAPHS}




\begin{tabular}{|l|l|}
\hline 24. & $\begin{array}{l}\text { GARCILASO DE LA VEGA } \\
\text { command Peter Martyr opened a school } \\
\text { at the Court for the youths of the nobility. } \\
\text { "My house is filled all day," he says, "with } \\
\text { a swarm of young nobles. Already they } \\
\text { are being gradually reclaimed from those } \\
\text { idle pursuits, to which they have been ac- } \\
\text { lustomed since their boyhood, to the study } \\
\text { of letters. Already they are beginning to } \\
\text { learn that letters are not a hindrance to } \\
\text { the profession of arms, as they have been } \\
\text { led to believe by their elders, but rather } \\
\text { a great assistance."1 Some of his pupils } \\
\text { attended his classes accompanied by their } \\
\text { tutors, with whom they reviewed the day's } \\
\text { lessons in the evening at home. So great } \\
\text { was the popularity of his instruction that } \\
\text { it was necessary a few years later to sum- } \\
\text { mon Lucio Marineo from his chair at } \\
\text { Salamanca to assist him in his work. With } \\
\text { such an enthusiasm current it was not } \\
\text { long before the old Castilian prejudice } \\
\text { against learning disappeared. We hear } \\
\text { of the Marquis of Denia learning Latin at } \\
\text { the age of sixty; Pedro Fernández de } \\
\text { Velasco, son of the Count of Haro, ex- }\end{array}$ \\
\hline H I S P A N I C N O T E S \\
\hline tong
\end{tabular}




\section{IFE A N D W R K S}

pounded Pliny and Ovid at Salamanca, and even the ladies of the Court, following the leadership of the Queen, set themselves to the task of mastering Latin and even Greek. ${ }^{1}$ As Prescott has so well remarked, "From a very early period, a courtly stamp was impressed on the poetic literature of Spain. A similar character was now imparted to its erudition; and men of the most illustrious birth seemed eager to lead the way in the difficult career of science, which was thrown open to the nation.".

At Toledo the spread of the new movement had been evidenced as early as $\mathrm{I}_{4} 85$ in the establishment of the Colegio de Santa Catalina by Francisco Álvarez, Maestrescuelas of the Cathedral. ${ }^{3}$ This school, which was raised to the status of a university in 1520 , numbered among its professors during the early years of the sixteenth century several of the most distinguished scholars in Spain. If Garcilaso received his early training in Toledo he must have sat under their instruction and

\section{A N D M O N O R A P H S}




\begin{tabular}{|c|c|}
\hline 26 & GARCILASO DE LA VEGA \\
\hline$\cdot$ & $\begin{array}{l}\text { it will be interesting to learn some of their } \\
\text { names. As early as I 507, Dionisio Váz- } \\
\text { quez (I479-I539) was professor of poetry } \\
\text { and oratory at Toledo, where he remained } \\
\text { until his appointment as the first inter- } \\
\text { preter of the Bible at the University of } \\
\text { Alcalá in I535. }{ }^{1} \text { The most famous of the } \\
\text { teachers of Toledo was Alfonso Cedillo, } \\
\text { whom Lucio Marineo styled "a man of } \\
\text { unusual learning, to whom the city of } \\
\text { Toledo, whose sons he so earnestly teaches, } \\
\text { is under the greatest obligation (virum } \\
\text { litteris insignem, cui quidem Toletana ci- } \\
\text { vitas, cuius filios diligentissime docet, plu- } \\
\text { rimum debet).". Cedillo was born in I484 } \\
\text { and for more than fifty years he gave out } \\
\text { his learning to his pupils, among whom } \\
\text { were Alejo Vanejas, author of the Primera } \\
\text { parte de las differencias de libros que ay en } \\
\text { el universo (I540), and Álvar Gómez de } \\
\text { Castro, writer of Latin verse and famous } \\
\text { as the biographer of the Cardinal Ximénez } \\
\text { de Cisneros. }{ }^{3} \text { The last of the teachers of } \\
\text { Toledo of whom there is mention is Juan } \\
\text { Ramírez, another of the masters of Âlvar }\end{array}$ \\
\hline & H I S A N I C NOTES \\
\hline
\end{tabular}




\section{LIFE A N D WORKS}

Gómez. Nicolás Antonio tells us that "he boarded noble youths at his house and instructed them in good manners and sound learning (Alebat domi adolescentes ingenuos, quos \& moribus \& literis probe instituebat)." 1 The high reputation which he enjoyed in his time is shown by his election to the chair of rhetoric at the University of Alcalá on the death of Antonio de Lebrija in $1522 .{ }^{2}$ Garcilaso nowhere mentions his early masters, but his own writings and particularly his Latin verses reveal how great was the debt he owed them.

There still remains the more important question of the method and scope of education in Spain in the first decades of the sixteenth century. In the absence of any definite studies on the subject, either by contemporaries or by modern scholars, we shall have to draw such conclusions as we can from other sources. Throughout the Middle Ages, in Spain as in the rest of Europe, the study of Latin and through it of the Seven Liberal Arts was the basis of all education. ${ }^{3}$ In spite of the interest

\section{A N D MONOGRAPH S}




\begin{tabular}{|c|c|}
\hline 28 & GARCILASO DE LA VEGA \\
\hline & $\begin{array}{l}\text { in the sciences revealed at the Court of } \\
\text { Alfonso the Learned, it is probable that in } \\
\text { general the Spaniards devoted most of } \\
\text { their efforts to the arts of the "Trivium," } \\
\text { grammar, rhetoric and logic; Isidore of } \\
\text { Seville, in his encyclopaedic Etymolo- } \\
\text { giarum libri } x x \text {, devotes more than three- } \\
\text { fourths of his discussion of the liberal arts } \\
\text { to the "Trivium" and more than a half to } \\
\text { grammar alone." It must be remembered } \\
\text { that the term "grammar" included in the } \\
\text { mind of the medieval teacher what is now } \\
\text { termed "language and literature"; but by } \\
\text { the end of the Middle Ages the purely } \\
\text { literary side was almost forgotten and a } \\
\text { scholastic dialectic on the niceties of usage } \\
\text { formed the substance of his instruction. } \\
\text { He was content to study letters in the } \\
\text { small doses quoted in Priscian's grammar } \\
\text { or in the metrical Doctrinale of Alexander } \\
\text { de Villadei, which had so largely replaced } \\
\text { it. } \\
\text { In a day when manuscripts were rare } \\
\text { and costly it was natural that most of the } \\
\text { instruction should be oral. The master }\end{array}$ \\
\hline & H I P A N I NOTES \\
\hline
\end{tabular}




\section{LIFE A N D W ORK S}

dictated to his pupils the rules of grammar and they committed these rules to memory. As soon as the elements of the language were thus imparted, he began the study of elementary texts. These texts, chosen rather for their moral than for their literary value, were commonly called the "authors" (auctores); the principal works were the Disticha Catonis, the collection of fables which they ascribed to Aesop, the De contemptu mundi, attributed to Saint Bernard, the Facetus, also known as the Morosus, - a collection of moral precepts, a similar work known as the Floretus, and the Ecloga of Theodulus. Written in verse, these works were readily committed to memory and thus served as a foundation for further teaching in the forms and syntax of Latin. In the more advanced stages of the study of grammar, the same methods were applied to the Priscianus minor, or to the Doctrinale. By the fourteenth century the classical authors, with the exception of Virgil, were almost wholly neglected. Nor was the study of rhetoric

\section{A N D MONOGRAPH S}




\begin{tabular}{|c|c|}
\hline 30 & GARCILASO DE LA VEGA \\
\hline & $\begin{array}{l}\text { concerned with classical usage; rhetoric } \\
\text { had been reduced to the learning of nota- } \\
\text { rial formulae (dictamina) and to the com- } \\
\text { position of epistles. Logic, which had } \\
\text { never been treated in its metaphysical } \\
\text { aspect, had been limited to instruction in } \\
\text { the subtleties of the syllogism. } \\
\text { Not the least of the contributions of the } \\
\text { Humanistic movement in Italy was its } \\
\text { reform of educational methods. }{ }^{1} \text { To Verge- } \\
\text { rius and to Vittorino da Feltre and } \\
\text { their followers, the modern world owes } \\
\text { not merely the restoration of the Clas- } \\
\text { sics as the only sound basis for the study } \\
\text { of grammar and rhetoric, but also the } \\
\text { establishment of the principle that educa- } \\
\text { tion aims at the training of the perfect } \\
\text { citizen and is essential not merely for the } \\
\text { cleric or the doctor, but also for every } \\
\text { man. Through their numerous treatises on } \\
\text { the theory and practise of education they } \\
\text { spread their doctrines during the fifteenth } \\
\text { century and by their text-books, such as } \\
\text { Perotti's Grammatices Rudimenta and the } \\
\text { Elegantiae of Lorenzo Valla and of Agos- }\end{array}$ \\
\hline & H I P A N I N N T E S \\
\hline
\end{tabular}




\section{LIFE AND WORKS}

tino Dati, they provided materials for a rational study of grammar and rhetoric. To what extent was their influence felt in Spain?

When Antonio de Lebrija returned to Spain in 1473 , he no doubt found the old régime in education still in full sway. Among the manuscripts in Queen Isabella's library are listed copies of the Priscianus minor and the Doctrinale. ${ }^{1}$ But the new movement was not long in making itself felt. One of the first books printed in Spain was the grammar of Perotti (I477) ${ }^{2}$ and four years later the publication of Lebrija's own Introductiones Latinae, ${ }^{3}$ so often reprinted in subsequent years, marks the turning point in the study of Latin. At about the same time appeared the first edition of Dati's Elegantiae to be issued from a Spanish press - there were three subsequent editions before the end of the century ${ }^{4}$ - and in 1490 Alfonso de Palencia printed his Latin-Spanish Vocabulario, ${ }^{5}$ to be followed in 1492 and 1495 by the two parts of Lebrija's dictionary. ${ }^{6}$ It

\section{A N D MONOGR A P H S}




\begin{tabular}{|c|c|}
\hline 32 & GARCILASO DE LA VEGA \\
\hline & $\begin{array}{l}\text { is significant of the popularity of the new } \\
\text { methods that all of these works, with the } \\
\text { exception of Perotti's grammar, were num- } \\
\text { bered in the library of Prince Juan, who } \\
\text { died in } 1497 .^{1} \text { It is difficult to determine } \\
\text { how far Lebrija and his Italian colleagues } \\
\text { in Spain, like Peter Martyr and Marineo, } \\
\text { attempted to carry the humanistic system } \\
\text { of education. Vergerius' important work, } \\
\text { De ingenuis moribus, was early known in } \\
\text { Spain through an edition printed at Bar- } \\
\text { celona in I } 48{ }^{2} \text { and Lebrija's little essay, } \\
\text { De liberis educandis, reveals an intimate } \\
\text { acquaintance with the educational theories } \\
\text { of Aristotle, Plutarch and Quintilian, to } \\
\text { whom the Italian educators as well had } \\
\text { turned for their doctrine. }{ }^{3} \text { Unfortunately, } \\
\text { Lebrija limits his study to the earliest } \\
\text { years of the child's life and we can only } \\
\text { divine that since he followed his masters } \\
\text { in his precepts for these years he must } \\
\text { also have used their methods in the later } \\
\text { training. } \\
\text { Even though Lebrija's Introductiones } \\
\text { had revolutionized the teaching of formal }\end{array}$ \\
\hline & H I P A N I N N T E S \\
\hline
\end{tabular}




\section{LIFE AND WORKS}

grammar in Spain, the elementary texts used by students long remained those that the Middle Ages had employed. There is a long list of editions of the various "auctores," such as the Disticha Catonis, the fables of Aesop, and the Ecloga of Theodolus, printed either singly or in a collection known as Libri minores, before the end of the century; ${ }^{1}$ Lebrija himself edited one of these collections which was first printed in 1525 at Alcalá, after his death. ${ }^{2}$ And the influence of the old method of studying rhetoric can be seen in the publication of such works as the Ars epistolandi of Franciscus Niger (I494) ${ }^{3}$ and the collection of Epistolae ex antiquorum annalibus excerptae made by Lucio Marineo.4 But the latter work is also significant because it shows that even if the Spanish humanists retained the art of epistolary composition as an important part of their study of rhetoric, they were now turning to the Classics for their models instead of the jejune formulae of the Middle Ages.

\section{A N D MONOGRAPHS}




\begin{tabular}{|c|c|}
\hline 34 & GARCILASO DE LA VEGA \\
\hline & $\begin{array}{l}\text { This phase of the revival of learning, } \\
\text { the study of the Classics, is a feature of } \\
\text { the movement in Spain as it was in Italy. } \\
\text { We have seen with what eagerness the } \\
\text { students of Salamanca crowded to hear } \\
\text { a lecture on Juvenal. But listening to } \\
\text { lectures does not make scholars; it is a } \\
\text { vicarious enjoyment of literature. What } \\
\text { we are interested to know is whether the } \\
\text { students themselves read and studied the } \\
\text { classical authors. For such a study the } \\
\text { first requisite is obviously texts. In } \\
\text { Spain there was no such activity in the } \\
\text { printing of classical authors as marked the } \\
\text { establishment of the press in Italy. But } \\
\text { a number of works were published in the } \\
\text { Peninsula. Of the prose writers, Sallust } \\
\text { and Caesar were printed during the fif- } \\
\text { teenth century, the former's Opera (Va- } \\
\text { lencia, I } 477 \text { ) being the second dated book } \\
\text { to be printed in Spain. The Latin poets } \\
\text { were more widely printed; Martial in } \\
\text { I } 490 \text {, the Metamorphoses of Ovid at about } \\
\text { the same time; Virgil's Buccolica et geor- } \\
\text { gica appeared in I498, his Aenead, in }\end{array}$ \\
\hline & H I P A N I C NOTES \\
\hline
\end{tabular}




\section{LIFE AND WORKS}

I $505 ;^{1}$ Persius was first printed at Seville in $1503 .{ }^{2}$ But this exhausts the list. As late as 1524 Lorenzo Balbo of Lille in the dedicatory epistle in the edition of the Argonautica of Valerius Flaccus explains that he and his colleagues in Latin literature at Alcalá had arranged to teach Virgil, Valerius Flaccus, Silvius Italicus, Cicero's Philippics and Quintus Curtius during the following winter but had found that aside from Virgil, not one of these authors was available. ${ }^{3}$ This condition was somewhat remedied, however, by the publication of his own edition of the Argonautica, and by editions of Cicero's Opuscula, and of Quintus Curtius. ${ }^{4}$ In the same year there also appeared the first Spanish edition of Terence. ${ }^{5}$ It is, of course, possible that in exceptional cases students were able to secure foreign editions or even manuscripts of the Classics: in the library of Prince Juan were printed editions of Terence and Pliny's Letters and a manuscript of Quintus Curtius; ${ }^{5}$ his mother's library contained numerous manu-

\section{A N D M O N O G A P H S}




\begin{tabular}{|c|c|}
\hline 36 & GARCILASO DE LA VEGA \\
\hline & $\begin{array}{l}\text { scripts of Latin authors. But we may } \\
\text { be sure that this was not true for the great } \\
\text { majority of students. And it is most im- } \\
\text { probable that Garcilaso enjoyed any such } \\
\text { advantages. For his immediate family } \\
\text { were apparently not enthusiastic about } \\
\text { the new learning. His father did not know } \\
\text { Latin and Martin de Viciana in his Libro } \\
\text { de alabanças d' las lenguas hebrea, griega, } \\
\text { latina, castellana, y valenciana (Valencia, } \\
\text { I } 574)^{1} \text { relates an anecdote of how, when } \\
\text { ambassador to the Pope, he delivered an } \\
\text { oration in Spanish at a certain poetical } \\
\text { contest on Saint Peter's day, I } 499 \text {, which } \\
\text { rivaled any of the compositions in Latin } \\
\text { and thereby demonstrated the superiority } \\
\text { of the Castilian tongue. The poet's uncle, } \\
\text { Lorenzo Suárez de Figueroa, was equally } \\
\text { innocent of Latin; Peter Martyr in one } \\
\text { of his letters to Ferdinand V, protests } \\
\text { bitterly against his being sent back to } \\
\text { Venice as ambassador, alleging that he } \\
\text { could neither understand his diplomatic } \\
\text { confrères nor be understood by them, } \\
\text { through his ignorance of the standard }\end{array}$ \\
\hline & H I S P N I C NOTES \\
\hline
\end{tabular}




\section{I F E A N D W O R K S}

language of diplomacy. Nor is it probable that Garcilaso's mother knew Latin, for among the books which she left at her death in 1537 , largely works of devotion, there was only one in Latin, a Vita Christi, and of this she also had a Castilian version. ${ }^{1}$

Latin was not the only language which the Spanish humanists cultivated. Lebrija was a distinguished scholar in Greek and made important contributions to its study, but his fame was surpassed in his time by that of the Portuguese Arias Barboso, professor at Salamanca. In spite of their lectures it is improbable that the study of Greek made any real progress in Spain until Cardinal Ximénez summoned to Alcalá Demetrius of Crete, Juan de Vergara and other Hellenists, to assist in the preparation of the Greek text of the Complutensian Polyglot and until Brocar, the famous printer of the University, made his first Greek types for that work and printed in $\mathrm{I}_{5} \mathrm{I}_{4}$ the Erotemata of Chrysoloras, the first Greek grammar

\section{A N D M O N O G R P H S}




\begin{tabular}{|c|c|}
\hline 38 & GARCILASO DE LA VEGA \\
\hline & $\begin{array}{l}\text { issued in Spain, and the Greek text of } \\
\text { Musaeus' Hero and Leander. } .^{1} \text { But even } \\
\text { this wave of interest soon subsided, leav- } \\
\text { ing only a few ripples of devotion to the } \\
\text { culture of the Greeks, and the Spanish } \\
\text { Renaissance was content to read its Greek } \\
\text { in Latin or Castilian translations. } \\
\text { There is one other feature of the human- } \\
\text { ist movement in Spain which deserves } \\
\text { mention; that is the critical study of their } \\
\text { own tongue. Lebrija's Gramaiica caste- } \\
\text { llana, published in I } 49^{2} \text {, }^{2} \text { antedates by } \\
\text { many years the earliest vernacular gram- } \\
\text { mars of Italian and French, for Gian- } \\
\text { francesco Fortunio's Regole gramaticali } \\
\text { was not published until I } 56^{3} \text { and the first } \\
\text { French grammar of French is the Trette } \\
\text { de la grammere françoeze (I550) of Louis } \\
\text { Meigret. The value of Lebrija's service, } \\
\text { to which he himself was fully alive, is not } \\
\text { easily to be overestimated. It gave to } \\
\text { Castilian usage a uniformity which was a } \\
\text { powerful force in the establishment of } \\
\text { good diction both in prose and poetry } \\
\text { and made possible the production, early }\end{array}$ \\
\hline & H I S A N IC NOTES \\
\hline
\end{tabular}




\section{IFE A N D W O K S}

in the sixteenth century, of such masterly prose as that of Juan de Valdés and such finished verse as that of Garcilaso. The pride which Lebrija evinces in the dignity and adequacy of Castilian as a vehicle for literary expression became a characteristic of the Spaniards and was reflected in their works. ${ }^{1}$

We may now venture to form some picture of the training in letters which Garcilaso as a boy received. As a child at home he must have learned to recite a few Latin prayers and hymns, so that when he first went to begin his lessons at the house of his master, he could understand the sounds of Latin. Through Lebrija's Introductiones, perhaps in the second edition, with its parallel passages of Latin and Castilian, he learned the rudiments of grammar. His first book was the Disticha Catonis. ${ }^{2}$ This and the other moral verses of its kind he committed to memory, for one of the chief tenets of humanistic education was the value of memory work: Italian boys of the period

\section{A N D MONOGRAPHS}




\begin{tabular}{|c|c|}
\hline 40 & GARCILASO DE LA VEGA \\
\hline & $\begin{array}{l}\text { could recite all of Sallust, the Aenead, } \\
\text { and other works, when they finished their } \\
\text { studies, and this must have been the prac- } \\
\text { tice in Spain as well. Then began the } \\
\text { study of the masters, first of all Virgil, } \\
\text { the great model, then Ovid, Martial and } \\
\text { Persius of the poets and Sallust and } \\
\text { Caesar of the historians. He was taught } \\
\text { to imitate their work in Latin verse and } \\
\text { prose of his own, and to write elegantly } \\
\text { Latin letters to his teacher and to his } \\
\text { friends. Perhaps too, he learned a smatter- } \\
\text { ing of Greek. Certainly he learned to } \\
\text { prize his own vigorous, majestic Castilian. } \\
\text { But his training was not all work; he must } \\
\text { be a broad, all-round man; and so he } \\
\text { was encouraged to run and ride and fence, } \\
\text { to build his body, and was taught to dance, } \\
\text { to play on instruments and sing, to fit } \\
\text { him for the social duties of life. His father } \\
\text { was dead, but his mother Doña Sancha } \\
\text { was solicitous of the welfare of her child- } \\
\text { ren; his brother was being prepared at } \\
\text { the Court to fill his place as head of the } \\
\text { house; he and his younger brother, Fran- }\end{array}$ \\
\hline & H ISPANIC NOTES \\
\hline
\end{tabular}




\section{IFE A N D W O R K S}

cisco de Guzmán, who later was Maestrescuelas at Badajoz, were receiving the training in letters and manners which befitted their noble station. And Garcilaso had no doubt already given evidence of unusual ability both in his studies and in in his sports. This is the sort of lad which we must picture, when one day in January, I5I6 word was brought to Toledo that King Ferdinand was dead.

\section{A N D M O O G R A H S}




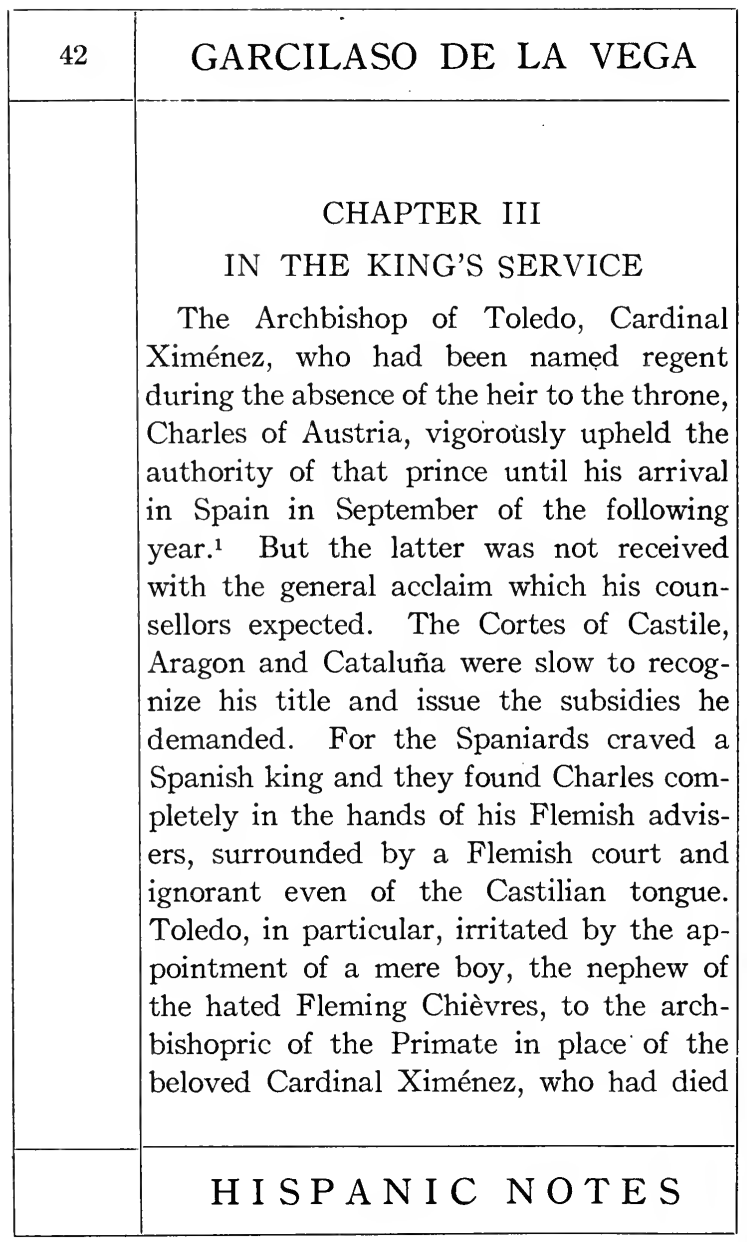




\section{I F E A D W O R K}

before he could reach the king to pay his allegiance, showed manifest signs of open revolt. At this juncture, the king received the news of his election as emperor and leaving Barcelona, hurried across Spain to embark for Flanders. At Santiago he hastily summoned the Cortes on April I, I520 to make further requisition upon his Castilian possessions to cover the expenses of his journey. His demands were met by determined protests and Garcilaso's brother, Pedro Laso de la Vega, who was one of the Toledan representatives, was so outspoken in his opposition that the king banished him to his fortress of Gibraltar, inherited from his father, granting him forty days in which to fulfill his command. ${ }^{1}$

Garcilaso must have joined the Court by this time and arrayed himself among the supporters of the king, for on the 26th of April Charles, who had transferred the Cortes to Corunna, appointed him a contino, or member of his personal guard, with a salary of 45,000 maravedís a year,

\section{A N D MONOGRAPHS}




\begin{tabular}{|c|c|}
\hline 44 & GARCILASO DE LA VEGA \\
\hline & $\begin{array}{l}\text { and a further grant of } 30,000 \text { maravedís } \\
\text { a year during his absence. }{ }^{1} \text { Garcilaso } \\
\text { promptly showed his gratitude and loyalty } \\
\text { by joining with the Condestable of Castile } \\
\text { in a request to one of the Toledan dele- } \\
\text { gates that he should go to Santiago and } \\
\text { urge upon his brother Pedro, who was } \\
\text { plainly delinquent in his obedience to the } \\
\text { king's commands, the desirability of has- } \\
\text { tening to Gibraltar in the five days which } \\
\text { still remained before the expiration of the } \\
\text { allotted time. }{ }^{2} \text { Pedro Laso was finally } \\
\text { moved to compliance and started upon } \\
\text { his journey. But unfortunately he stopped } \\
\text { at his estate of Cuerva near Toledo, and } \\
\text { there he was discovered by his fellow citi- } \\
\text { zens, who came in a body and escorted } \\
\text { him back to the city in triumph. Toledo } \\
\text { was in open revolt. } \\
\text { The news of the situation reached Co- } \\
\text { runna on May }{ }^{4} \text { and the } 20 t h \text { of the month } \\
\text { Charles sailed, }{ }^{5} \text { leaving as his viceroys the } \\
\text { Cardinal, Adrian of Utrecht, the Condes- } \\
\text { table of Castile, and the Almirante of } \\
\text { Castile. During the two years of struggle }\end{array}$ \\
\hline & H I S P N I C NOTES \\
\hline
\end{tabular}




\section{IFE A N D WORKS}

which followed in the task of repressing the Comunidades, Garcilaso served under the colors of Juan de Rivera, captain of the royal forces. ${ }^{1}$ That he showed himself to be a brave and daring soldier in this, his maiden venture in arms, we are assured by the reports of his captain. and at the battle of Olías, on August I $_{7}$, I $_{5} 2 \mathrm{I}$, when the Toledans, who were in no small straits for provisions, came forth to scour the countryside, he received a wound in the face. $^{2}$ The campaign ended in a victory for the royal forces with the surrender of Toledo on October 25, I52I. But the fires of animosity were still smouldering and on February 2 in the following year once more broke into flame. The rebels fortised themselves in the house of Dona María Pacheco, widow of the ill-fated Juan de Faúíilla, and for a time successfully defended themselves against the authorities. The house of the Padillas was next to that of Garcilaso and an attempt was made to penetrate the castie of the insurgents through the latter's yard. The ruse

\section{A N D M O N G R A P S}




\begin{tabular}{|c|c|}
\hline 46 & GARCILASO DE LA VEGA \\
\hline & $\begin{array}{l}\text { was discovered in time and thwarted. But } \\
\text { the odds were too great and the leaders } \\
\text { of the revolt finally surrendered on condi- } \\
\text { tion that they be allowed to leave the } \\
\text { city unharmed. } \\
\text { Meanwhile the Spanish king had been } \\
\text { crowned emperor as Charles V on October } \\
23 \text {, I52I at Aix-la-Chapelle. In the fol- } \\
\text { lowing year after a brief visit with Henry } \\
\text { VIII in England, he embarked at South- } \\
\text { ampton and on July I6th landed at } \\
\text { Santander." On August 5th he reached } \\
\text { Palencia, where he found the nobles of } \\
\text { his Spanish court assembled in such num- } \\
\text { bers, according to Martin de Salinas, that } \\
\text { "there was not room for them all standing } \\
\text { (no cabemos de pies)". }{ }^{3} \text { As a contino of } \\
\text { the royal house, Garcilaso must have been } \\
\text { numbered in this throng; perhaps he was } \\
\text { also one of the many who were eager to } \\
\text { urge their claims for reward for loyal ser- } \\
\text { vice to the Emperor. But even before } \\
\text { the Court left Palencia there had arrived } \\
\text { from Italy news of an alarming nature } \\
\text { which was to affect Garcilaso's experience. }\end{array}$ \\
\hline & H I PANIC NOTES \\
\hline
\end{tabular}




\section{I F E A N D W O R K S}

\section{CHAPTER IV}

\section{AN ILL FATED EXPEDITION}

Since the beginning of the fourteenth century the Knights of St. John of Jerusalem had held the island of Rhodes as a bulwark of Christianity against the infidels. ${ }^{1}$ The latter had made several unsuccessful attempts to take the citadel by siege. With the accession of Solyman the Magnificent, they once more took up their plans for the conquest of Christendom and on June I, I522 the Sultan had sent to the Grand Master of Rhodes, Villiers de l'Isle-Adam, a peremptory demand to surrender the island. ${ }^{2}$ His message reached Rhodes on the 14 th and on the morning of the 26th the vast fleet of the Turks appeared off the harbor. That night the Grand Master dispatched messengers to the Pope and the-various sovereigns of Europe, warning them of the peril to the Order and to the whole of

\section{A N D MONOGRAPH S}




\begin{tabular}{|l|l|}
\hline 48 & $\begin{array}{l}\text { GARCILASO DE LA VEGA } \\
\text { Christendom and imploring their aid. It } \\
\text { was a month before these messengers } \\
\text { reached Rome. Adrian VI, recently } \\
\text { elected Pope, was still in Spain, but the } \\
\text { College of Cardinals wrote to Charles V } \\
\text { on July 26th, informing him of the situa- } \\
\text { tion and urging him to send prompt suc- } \\
\text { cor. }{ }^{1} \text { Their letter reached the Emperor at } \\
\text { Palencia. The latter, on August 25th, just } \\
\text { before his departure for Valladolid, wrote } \\
\text { to La Chaux that he had received the news, } \\
\text { was writing to his allies and to the other } \\
\text { Powers of Europe to take energetic action, } \\
\text { and had himself issued orders to his vice- } \\
\text { roys at Naples and in Sicily to give every } \\
\text { possible aid. }{ }^{2} \text { Immediately upon his ar- } \\
\text { rival at Valladolid (August 27) he sum- } \\
\text { moned a council of the nobles and prelates } \\
\text { of the realm to discuss what measures } \\
\text { should be taken; at the same time there } \\
\text { arrived the special envoy of the Grand } \\
\text { Master of Rhodes, to emphasize the urgen- } \\
\text { cy of the situation. }{ }^{3} \\
\text { The Prior of Castile of the Order of St. } \\
\text { John, Diego de Toledo, was the leader in }\end{array}$ \\
\hline H I S P A N I C N O T E S \\
\hline
\end{tabular}




\section{LIFE A N D WORK S}

the effort to bring some real assistance to the beleaguered knights. Don Diego had been forced at the behest of Pope Leo $\mathrm{X}$ to share his revenues as Prior of the Order with Antonio de Zúniga, ${ }^{1}$ but he had been generally recognized in Castile as the true incumbent of the office and he now gave abundant proof that his claim was justified. He soon gathered about him a considerable company of nobles with the intent of bearing personal relief to Rhodes. Among those who rallied to his call were his brother Pedro de Toledo, Diego de Acevedo, the young poet Juan Boscán, and also Garcilaso de la V'ega.

It is interesting to find that thus, at the very beginning of his career, Garcilaso was brought into the closest intimacy with at least two of the men who were to be his truest friends throughout his life. Pedro de Toledo ${ }^{3}$ later Marquis of Villafranca and viceroy of Naples, was one of the younger sons of the Duke of Alba, and uncle of Hernán Álvarez de Toledo, heir to the duchy, whose father Don García

\section{A N D MONOGRAPHS}




\begin{tabular}{|c|c|}
\hline 50 & GARCILASO DE LA VEGA \\
\hline & $\begin{array}{l}\text { had been killed in the expedition to Africa } \\
\text { in I } 5 \text { Io. We shall have frequent occasion } \\
\text { to mention the warm friendship which he } \\
\text { felt for Garcilaso. Of the latter's friend- } \\
\text { ship with Boscán, - a friendship which } \\
\text { lasted even in death - so much has been } \\
\text { written that it needs no comment here. } \\
\text { Suffice it to say that to their mutual } \\
\text { encouragement and emulation was due in } \\
\text { no small measure the triumph of their } \\
\text { literary experiments. } \\
\text { The gallant company of Spanish gentle- } \\
\text { men left Valladolid or the last day of } \\
\text { September. }{ }^{2} \text { Crossing Spain, they em- } \\
\text { barked at Cartagena for Messina. Their } \\
\text { carrack was attacked by a fleet of Alger- } \\
\text { ian corsairs and their plight seemed des- } \\
\text { perate, for the main-mast was shot away } \\
\text { and their rigging wrecked. Even though } \\
\text { they received several shots below the } \\
\text { water-line, they still fought on, determined } \\
\text { to burn their ship rather than surrender } \\
\text { the banner of St. John to the infidels. } \\
\text { But happily, with their last broadside, } \\
\text { they sank the flagship of the enemy and }\end{array}$ \\
\hline & H I P A N I C NOTES \\
\hline
\end{tabular}




\section{I F E A D W O R K S}

while the corsairs were engaged in the rescue of their chief, succeeded in escaping. Having made the port of Ibiza in the Balearic Islands, they spent some weeks in refitting their ship and at last reached Messina at the beginning of December. There they found that the measures for gathering the relief expedition were meeting with little success. Some of the sovereigns, like Henry VIII of England, had refused to send any aid; others, like Francis I and the Pope Adrian VI, were so hesitant, in their fear of exposing themselves to an attack from their enemies, that their forces were still awaiting equipment. And finally, the several expeditions outfitted and manned by the members of the Order in different countries suffered a worse fate than the company of Diego de Toledo. Some were attacked by corsairs, others were sunk in the terrible storms which raged on the Mediterranean that winter and not one of these little fleets reached Messina unscathed. By the middle of January only four more ships

\section{A N D MONOGRAP H S}




\begin{tabular}{|c|c|}
\hline 52 & GARCILASO DE LA VEGA \\
\hline & $\begin{array}{l}\text { had reached that harbor, while seven } \\
\text { others were still lying at Naples, waiting for } \\
\text { favorable weather. }{ }^{1} \\
\text { Meanwhile, unaided, against terrific } \\
\text { odds, the little band of knights at Rhodes } \\
\text { had resisted the attacks of the Turks. But } \\
\text { in spite of their heroic efforts they had } \\
\text { been gradually forced to relinquish their } \\
\text { defenses. Their bastions were battered } \\
\text { and mined; the enemy had constructed } \\
\text { a huge mound which overtopped the cita- } \\
\text { del and which enabled them to subject } \\
\text { the defenders to a merciless bombardment. } \\
\text { At last they were reduced to such straits } \\
\text { that they had scarcely ground left to de- } \\
\text { fend. It was then, on December } 2 \text { oth, } \\
\text { that the Grand Master, despairing of } \\
\text { relief from the West, opened negotiations } \\
\text { with the enemy. He was granted the } \\
\text { right to depart with all of his knights. On } \\
\text { Christmas Day, the Turks entered the city. } \\
\text { The news of the surrender was long in } \\
\text { reaching Italy and even after authentic } \\
\text { confirmation had come through the ar- } \\
\text { rival of Gabriele da Martinengo, a knight }\end{array}$ \\
\hline & H I P A N I C NOTES \\
\hline
\end{tabular}




\section{LIFE AND WORKS}

of the Order dispatched by the Grand Master, at Gallipoli in Puglia, the Italians were loath to admit its accuracy. The Pope said on first hearing the report, "I refuse to believe it yet," and at Naples, bets were offered at odds of five to one that the story was false. The Venetians in particular, who might have saved the island had they been willing to turn a hand, were conscience-stricken at their betrayal of Christianity. But the grievous news proved to be only too true. Martinengo reached Messina and checked the preparations for the expedition. The rest of the knights and the Christian inhabitants of the island were beset by illness and by storms on their journey to Messina. A part of the company reached the harbor late in March; not until the beginning of May did the Grand Master enter the port, flying at his masthead, in lieu of the banner of the Order, a flag bearing an image of the Virgin with the dead Christ in her arms and the inscription "Afflictis spes unica rebus."

\section{A N D MONOGRAP H S}




\begin{tabular}{|c|c|}
\hline 54 & GARCILASO DE LA VEGA \\
\hline & $\begin{array}{l}\text { The first thought of the Grand Master } \\
\text { after his arrival was to investigate the } \\
\text { failure of his knights in Europe to bring } \\
\text { the aid he had called for. To this end he } \\
\text { at once called a council of the Order and } \\
\text { arraigned the several Priors. Diego de } \\
\text { Toledo, in behalf of Castile and Portugal, } \\
\text { and the others explained the difficulties } \\
\text { which they had met, recounting the losses } \\
\text { they had suffered and the impossibility of } \\
\text { sailing in such storms as had beset them. } \\
\text { When the long story of their trials was } \\
\text { finished, the Grand Master cried, "God } \\
\text { be forever praised, for in our common mis- } \\
\text { hap he has granted me the favor of the } \\
\text { knowledge that never shall it be said that } \\
\text { our misfortunes were due to the negligence } \\
\text { of any of my knights." But even at Mes- } \\
\text { sina the knights were subjected to further } \\
\text { trials, for the plague broke out in their } \\
\text { midst. Once more then they embarked } \\
\text { and sought refuge near Baiae on the ruins } \\
\text { of ancient Cumae, where they remained } \\
\text { until they were granted a temporary asy- } \\
\text { lum by the Pope at Cività Vecchia. }\end{array}$ \\
\hline & H I P A N IC NOTES \\
\hline
\end{tabular}




\section{I F E A N D W O R K S}

Such is the story of this ill-fated expedition. We do not know how Garcilaso bore himself in it; in fact our knowledge that he participated is due merely to a line in the Carlo famoso of Luis Zapata. But it marks a period of the greatest importance in his life in the friendships which he made during these long months of struggle with pirates and with the sea and of weary waiting. He must have returned to Spain before Diego de Toledo, who did not reach the Court until December $5^{\text {th }}$, $1523,{ }^{1}$ for he was in Valladolid before the Emperor departed at the end of August.2

\section{A N D M O N O R A P.H S}




\begin{tabular}{|c|c|}
\hline 56 & GARCILASO DE LA VEGA \\
\hline & $\begin{array}{l}\text { CHAPTER V } \\
\text { KNIGHTHOOD AND MARRIAGE } \\
\text { The Court to which Garcilaso returned } \\
\text { was of a very different character from that } \\
\text { which he had seen in I } 5^{20} \text {. For Charles } \\
\mathrm{V} \text { had made his first visit to Spain a } \\
\text { purely business trip; his only thought was } \\
\text { to extract such revenues as he could from } \\
\text { the several Cortes. But he had now re- } \\
\text { turned to stay and was apparently in a } \\
\text { more conciliatory spirit toward his sub- } \\
\text { jects. For a year the Court had been es- } \\
\text { tablished in Valladolid; on All Saint's Day, } \\
\text { I } 5^{22} \text {, he had issued a general pardon to } \\
\text { those who had taken part in the revolt of } \\
\text { the Comunidades, although some two hun- } \\
\text { dred and seventy names were excepted, } \\
\text { among them that of Pedro Laso de la Vega, } \\
\text { whose return to the royal cause had failed } \\
\text { to win him favor; finally at the session of } \\
\text { the Cortes held in August, I } 5^{23} \text {, he had } \\
\text { granted the greater part of the fourteen } \\
\text { demands presented by his subjects, de- }\end{array}$ \\
\hline & H I SPAN IC NOTES \\
\hline
\end{tabular}




\section{LIFE A N D WORKS}

mands which in large measure were but a repetition of the pleas for reform for which the Comunidades had fought. Not the least among them was the demand that henceforth none but Spaniards should be named as officers of the royal household. ${ }^{1}$ There was another respect in which the life of the Court was changed. Charles $V$, after several projects for advantageous marriages had come to nought, was still a bachelor. But in June, ${ }^{5} 23$ his older sister, Eleanor of Austria, who had been left a widow in I52I, after two years of married life with Emanuel I of Portugal, returned to Spain with the ladies of her suite and established herself at Court. ${ }^{2}$ Her palace at once became the social centre of the kingdom;3 for the first time since the death of Queen Isabella the young nobility found a field for its gallantry.

It is not surprising that in these new conditions Garcilaso found especial favor. Herrera tells us that he was a favorite with the ladies of the Court because of his noble birth, his knowledge of letters,

\section{A N D MONOGRAPHS}




\begin{tabular}{|c|c|}
\hline 58 & GARCILASO DE LA VEGA \\
\hline & $\begin{array}{l}\text { the elegance of his verses and his gallant } \\
\text { manners. }{ }^{1} \text { And we may well believe that } \\
\text { this brave young knight, freshly returned } \\
\text { from an adventure that had much which } \\
\text { was romantic about it, was at once re- } \\
\text { ceived with enthusiasm by the circle of } \\
\text { Dona Leonor. From the Emperor he re- } \\
\text { ceived even more solid evidences of favor. } \\
\text { At the Chapter of the Order of Santiago } \\
\text { which was concluded on August } 25 \text { th, the } \\
\text { day that the Court left Valladolid, Gar- } \\
\text { cilaso was one of the twenty-eight gentle- } \\
\text { men, out of the two hundred and ten or } \\
\text { more who craved admission, who were } \\
\text { honored with knighthood in that Order. } \\
\text { It is easy to see in his appointment the } \\
\text { influence of Pedro de Toledo, for the latter } \\
\text { was Comendador of Monreal in the Order } \\
\text { of Santiago. The Emperor and his court } \\
\text { reached Burgos on the } 29 \text { th. }{ }^{3} \text { There on } \\
\text { September I Ith, Garcilaso presented his } \\
\text { prueba of nobility, with Pero Abrera of } \\
\text { Cordova as his witness and on the I6th } \\
\text { Charles V issued the cédula of his appoint- } \\
\text { ment to the habit and insignia of Santiago. }{ }^{5}\end{array}$ \\
\hline & H I P A N I C NOTES \\
\hline
\end{tabular}




\section{IFE A N D WORK S}

At least a part of the Emperor's willingness to accede to the demands of the Cortes was due to his desire to gain its support in his project for the invasion of France by way of Navarre. This plan he now proceeded to carry out. The expedition was after all popular with the Spaniards, who had not forgotten the invasion of Navarre by the French two years before, nor their continued occupation of Fuenterrabía. The Emperor left Burgos on September i6th for Logroño, where he remained until the $9^{\text {th }}$ of October, organizing his campaign. On the rst of the month he issued a list of the Spanish members of his household, appointed in accordance with his promise to the Cortes; among them Garcilaso was named a "gentleman of the House of Flanders." 1 For the next seven years we shall find him constantly in the service of the Emperor. The chief elements of the invading army were now ready. The Condestable of Castile was named commander, while the Prince of Orange was placed in charge of

\section{A N D MONOGRAPH S}




\begin{tabular}{|c|c|}
\hline 60 & GARCILASO DE LA VEGA \\
\hline & $\begin{array}{l}\text { the Spanish infantry and Rocandorf in } \\
\text { charge of the Germans. In all they num- } \\
\text { bered thirty thousand infantry and three } \\
\text { thousand knights, together with such a } \\
\text { provision of artillery as never before had } \\
\text { been seen in Spain. This force mobilized } \\
\text { in Pamplona by the middle of October and } \\
\text { early in November the first units began } \\
\text { to cross the Pyrenees by way of San Juan } \\
\text { de Pie de Puerto and Roncesvalles. } \\
\text { Garcilaso was one of the gentlemen of the } \\
\text { Court who took part in this campaign, but } \\
\text { before his departure he was armed a knight } \\
\text { of Santiago in the monastery of San } \\
\text { Agostín in Pamplona on the I Ith of } \\
\text { November. }{ }^{2} \text { It was his friend and pro- } \\
\text { tector Pedro de Toledo who dubbed him } \\
\text { knight; among the witnesses was his } \\
\text { brother-in-law, Luis Puertocarrero, Count } \\
\text { of Palma. The first stages of the invasion } \\
\text { were marked by successes, in spite of an } \\
\text { early winter and an exceptionally heavy } \\
\text { snowfall. Once across the Pyrenees, the } \\
\text { Spaniards captured Monleón (Mauléon) } \\
\text { on the } 4 \text { th of December and after a brief }\end{array}$ \\
\hline & H I S P N I C NOTES \\
\hline
\end{tabular}




\section{I F A N D W O R K S}

siege, entered Salvatierra (Sauveterre) on the I $^{\text {th. }}{ }^{1}$ Here Garcilaso was quartered in the house of a surgeon. Six years later when he drew up his will, he remembered that he had not paid him for his maintenance. ${ }^{2}$ Plainly those were days when the sense of personal honor was still strong in war. The initial successes, however, were not followed up. Instead of pushing on to Bayonne, the Spanish generals decided to turn back and lay siege to Fuenterrabía. The undertaking proved difficult; it was the $27^{\text {th }}$ of February in the following year before the garrison surrendered and the Spanish forces entered the town. ${ }^{3}$ Perhaps it was during this siege that Garcilaso first came to know Fernán Álvarez de Toledo, heir to the duchy of Alba. For it was here for the first time that the young knight, although but sixteen years of age, served in the field against the enemy, and this, as Peter Martyr tells us, in spite of his grandfather's express prohibition. ${ }^{4}$

Fernán Álvarez, who, as we have seen,

\section{A N D MONOGRA P H S}




\begin{tabular}{|c|c|}
\hline 62 & GARCILASO DE LA VEGA \\
\hline & 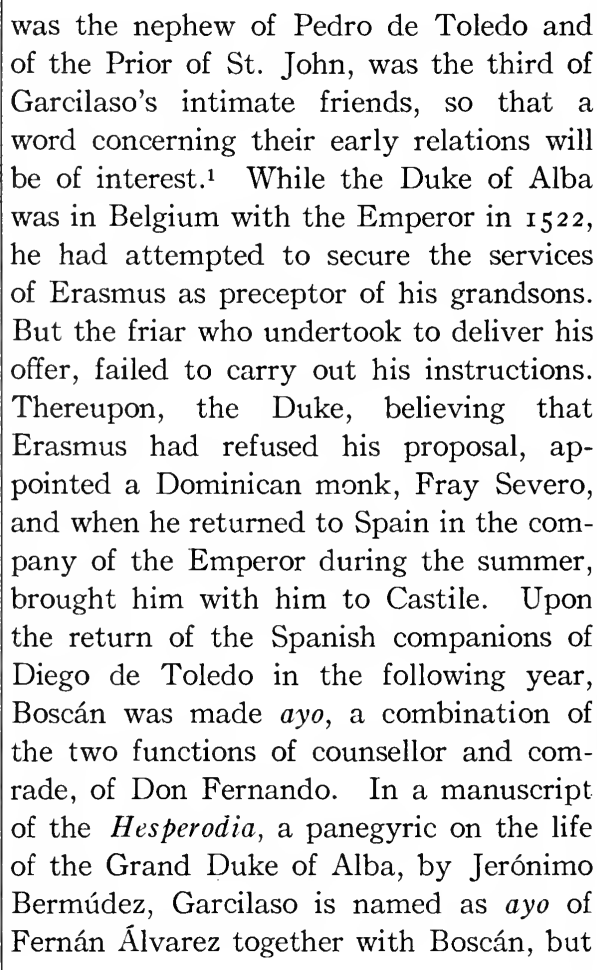 \\
\hline & H I P A N I N OTES \\
\hline
\end{tabular}




\section{I F E A D WORKS}

it is unlikely that this is true, for Garcilaso makes no mention of such a relation between himself and Don Fernando, of which he might well have been proud, in the passage in his second Eclogue where he describes the latter's training and speaks in such definite terms of Severo and Boscán. It is nevertheless certain that he was on terms of the closest intimacy with Don Fernando as with the other members of his family. One of his earliest compositions, the villancico on the theme "Qué testimonios son estos" was one of a group of verses dedicated to Luis de la Cueva "because he danced at Court with a lady whom they called 'La Páxara' ".' The other versifiers were, the Duke of Alba, the Prior of St. John, Boscán, Fernán Ảlvarez de Toledo, the Clavero of Alcántara (another of the sons of the Duke of Alba), Luis Osorio, García de Toledo, Gutierre López de Padilla and the Marquis of Villafranca. It is an interesting family group; not one of the house of Toledo is missing. And sinceit includes the name of the Duke as

\section{A N D M O O G R A H S}




\begin{tabular}{|c|c|}
\hline 64 & GARCILASO DE LA VEGA \\
\hline & $\begin{array}{l}\text { among those at Court, the verses must have } \\
\text { been written before I } 53 \mathrm{I}^{1} \text { The fortunes } \\
\text { of Garcilaso are at every point in contact } \\
\text { with his protectors of the house of Toledo. } \\
\text { We are ignorant of the whereabouts of } \\
\text { Garcilaso during the year which followed } \\
\text { the fall of Fuenterrabía. Having achieved } \\
\text { this small success, the Emperor disbanded } \\
\text { his Spanish troops and returned to Burgos } \\
\text { with his Court. It is probable, however, } \\
\text { that Garcilaso spent the year at the monas- } \\
\text { tery of Uclés as a novice of the Order of } \\
\text { Santiago in fulfillment of the express } \\
\text { orders issued by the Emperor in the cédula } \\
\text { of his appointment. }{ }^{2} \text { As soon as the period } \\
\text { of his noviciate was ended, he must have } \\
\text { returned to the service of the Emperor, } \\
\text { and this brings us to an interesting event } \\
\text { in his life. } \\
\text { Among the ladies of the suite of Eleanor } \\
\text { of Austria, who did so much to enliven the } \\
\text { atmosphere of the Court, Garcilaso had } \\
\text { early met Doña Elena de Zúniga, daughter } \\
\text { of İñgo de Zúñiga, maestresala of Queen } \\
\text { Isabella. If we might believe Andreas }\end{array}$ \\
\hline & H I S P N I C NOTES \\
\hline
\end{tabular}




\section{I F E A N.D W O R K S}

Schott, Dona Elena had succumbed to the blandishments of the verses which Garcilaso was wont to lavish upon the fair ladies. ${ }^{1}$ It is possible that some of the verses in Castilian metres which have survived as Garcilaso's were addressed to her; such compositions as his "Acaso supo, a mi ver," are sufficiently colorless and impersonal to apply to any or all of the ladies of the Court. At least we may be sure that the success of Garcilaso's suit for her hand made him an object of envy. Doña Elena came from a family which could trace its ancestry to as $\operatorname{dim}$ a past as his own; ${ }^{2}$ what was of even greater moment in those days, the Emperor and his sister Eleanor approved of the marriage. The extent of their approval is revealed in certain financial documents which have been preserved. On August 25, I525, the Emperor made a grant of 60,000 maravedís a year to Garcilaso, with order that the first three years should be paid to him together on January ist of the following year. ${ }^{3}$ Two days later the usual marriage

\section{A N D M O N O R A P H S}




\begin{tabular}{|c|c|}
\hline 66 & GARCILASO DE LA VEGA \\
\hline & $\begin{array}{l}\text { contracts were drawn up by Doña Elena } \\
\text { and Garcilaso. From them it appears that } \\
\text { Doña Elena brought as her dowry } 2,575, \\
000 \text { maravedis (a little less than } 7,000 \\
\text { ducats), of which she had received I, } \\
000 \text {, } \\
\text { King of Porttugal, and } 375,000 \text { from Eleanor } \\
\text { of Austria. The dower which Garcilaso } \\
\text { settled upon her was } 2,000 \text { ducats, one- } \\
\text { tenth of his total estate of } 20,000 \text { ducats. } \\
\text { It is difficult to give any precise meaning } \\
\text { to these figures in terms of modern cur- } \\
\text { rency or modern buying power. But if } \\
\text { we remark that the annual grant made to } \\
\text { Garcilaso of } 60,000 \text { maravedis (I6o ducats) } \\
\text { must have been regarded as sufficient for } \\
\text { his maintenance and if, three years later } \\
\text { he was able to purchase a house in Toledo } \\
\text { at a cost of } 550,000 \text { maravedís (I } 466 \\
\text { ducats), it becomes plain that Garcilaso's } \\
\text { fortune and his bride's dowry were con- } \\
\text { siderable according to the standards of } \\
\text { the time, which is the more interesting be- } \\
\text { cause Garcilaso was not the heir to his } \\
\text { father's estates. }\end{array}$ \\
\hline & H I S A N IC NOTES \\
\hline
\end{tabular}




\section{I F E A N W O R K S}

We may assume these contracts were immediately followed by the ceremonies of betrothal and marriage and that since the Court was then in Toledo, the young couple took up their residence at the house of Garcilaso's mother, Doña Sancha de Guzmán. It is not easy to judge what were Garcilaso's relations with his wife. There is not one mention of her in all of his writings, unless we except his last will and testament. On the other hand, the sincerest and most ardent of his poems were inspired by Isabel Freire, whom we shall presently meet. It cannot be said that this neglect of one's wife for some other mistress was merely a conventional, poetic pose of the time, for Boscán's noblest verses are those that reveal his devotion to his wife, Doña Ana Girón de Rebolledo. If we may judge by numerous other examples of court practice, such as the union of the Marchioness of Cenete with the Count of Nassau, marriages were not made in heaven in the early sixteenth century. Doña Elena was the lady of the

\section{A N D MONOG R P H S}




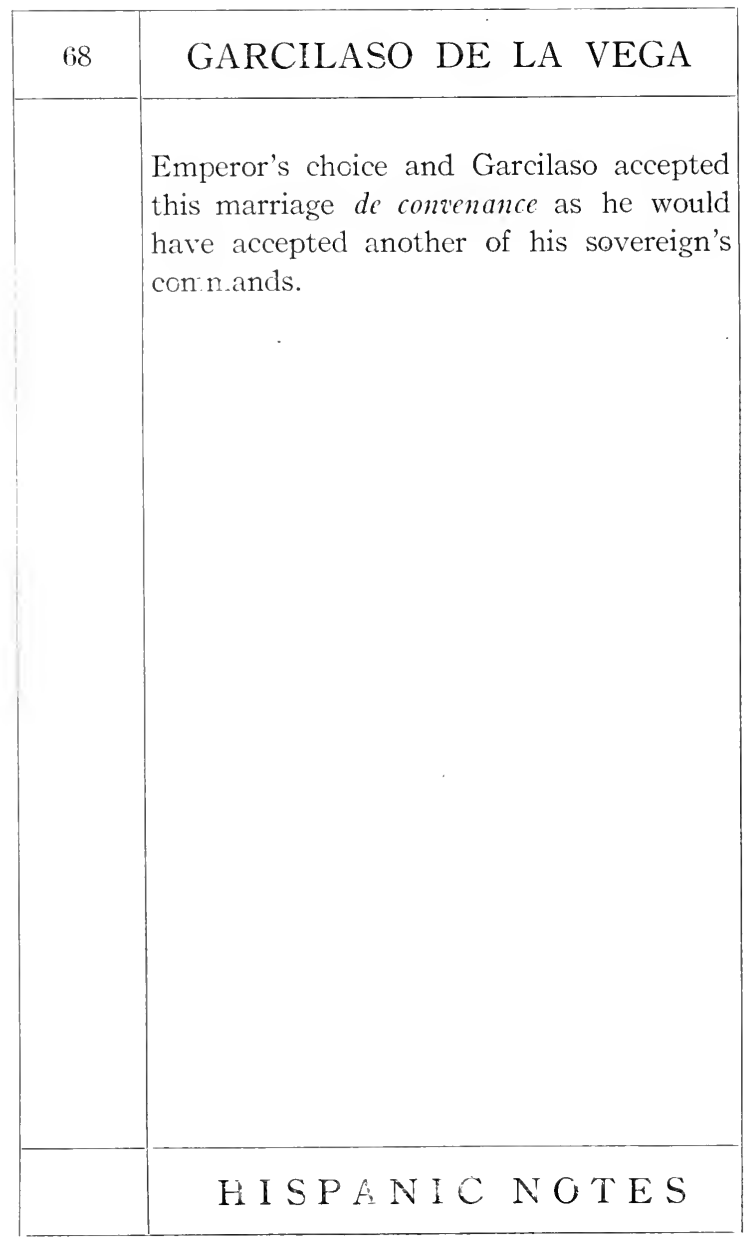




\section{I F E A D WORKS}

\section{CHAPTER VI}

\section{A COLRTIER OF THE EMPEROR}

These years in which Charles had been specializing as king of Spain had also been a season of prosperity for the Imperial arms in Italy. On March 3 rd of the year in which Garcilaso was married there reached Madrid the glad tidings that on the Emperor's birthday, February 24th. the armies of France had been defeated at Pavia and the king, Francis I, made a prisoner. ${ }^{1}$ Almost immediately after the latter's arrival at Madrid in August under the guard of the Viceroy of Naples, the long discussion over the terms of peace between Charles and Francis began. On one point both of the monarchs were ready to agree, that Francis I should marry Charles" sister Eleanor of Austria. But the other conditions were not so easily settled as these family matters. Doña Eleanor left Toledo on October 6th for Talavera, where she remained "in bond

\section{A N D MONOGRAPHS}




\begin{tabular}{|c|c|}
\hline 70 & GARCILASO DE LA VEGA \\
\hline & $\begin{array}{l}\text { (en depósito)", as Martín de Salinas put } \\
\text { it, awaiting the outcome of the negoti- } \\
\text { ations. }{ }^{1} \text { At last on January I } 4 \text {, I } 526 \text {, the } \\
\text { treaty between the kings was signed at } \\
\text { Madrid. On the } 2 \text { oth of the month Queen } \\
\text { Germana, widow of Ferdinand V, and now } \\
\text { once more widow of the Marquis of Branden- } \\
\text { burg, reached Toledo. The Emperor in } \\
\text { person, attended by the principal nobles of } \\
\text { the Court, among them the Duke of Alba } \\
\text { and Diego de Toledo, rode out to Santa } \\
\text { Lucía to escort her to the city. It was dark } \\
\text { when they crossed the bridge of Alcántara, } \\
\text { so that the pages of the company had to } \\
\text { light their way with torches through the nar- } \\
\text { row streets till they reached the houses of } \\
\text { Garcilaso de la Vega, which had been as- } \\
\text { signed to her for her lodging, as being among } \\
\text { the best in Toledo. } \\
\text { Her stay as a guest of Garcilaso was brief, } \\
\text { for within a few days she started for Torrijos } \\
\text { to meet Queen Eleanor. But on the Ist of } \\
\text { February the two queens returned to Toledo } \\
\text { and we may assume that she was again } \\
\text { lodged at the house of Garcilaso. It is inter- }\end{array}$ \\
\hline & H I P A N I NOTES \\
\hline
\end{tabular}




\section{IFE A N D W O R K}

esting to find this intimacy between Doña Germana and Doña Eleanor, for Garcilaso's wife, Doña Elena de Zúñiga was, as we have seen, a lady-in-waiting of the latter. Under these circumstances it is unquestionable that both Garcilaso and his wife were numbered in the suite of the Queens when they went to Illescas on the I6th of February to meet the king of France, who was then at Torrejón with the Emperor. Perhaps, too, they were among the gentlemen and ladies who danced before the sovereigns on the following days. As soon as Francis I left for France, Charles $\mathrm{V}$ returned to Illescas to take leave of his sister, before starting for Seville, where he was to be married to Isabella of Portugal. On the day that he set out on his journey, February 22nd, Doña Eleanor and Doña Germana returned to Toledo with their suites. Three days later they separated, Doña Germana starting for Seville and Doña Eleanor for Vitoria in the wake of her royal fiancé. ${ }^{1}$

Among the company that left Toledo on the $24^{\text {th }}$ and $25^{\text {th }}$ when the Court departed

\section{A N D M O N G R A P H S}




\begin{tabular}{|c|c|}
\hline 72 & GARCILASO DE LA VEGA \\
\hline & $\begin{array}{l}\text { for Seville were the ambassadors of the for- } \\
\text { eign powers. }{ }^{1} \text { Two of them at least must } \\
\text { have been known to Garcilaso, Andrea Nava- } \\
\text { gero, ambassador of the Serene Republic, } \\
\text { and Baldassare Castiglione, Papal Nuncio, } \\
\text { who had come to Spain in the preceding } \\
\text { year. They were both men of letters and it } \\
\text { is to them that we must attribute the first } \\
\text { interest in Tuscan literature which Garcilaso } \\
\text { and his friend Boscán did no much to further. } \\
\text { It is possible that Garcilaso accompanied } \\
\text { them on this journey to Seville, which they } \\
\text { made by way of Guadelupe, while the Em- } \\
\text { peror followed the road through Trujillo and } \\
\text { Mérida. They reached Seville on March } \\
\text { 8th, two days before the Emperor, who had } \\
\text { stopped for several days at Oropesa. They } \\
\text { found Isabella of Portugal already arrived } \\
\text { with her suite. At midnight of the day of } \\
\text { Charles V's arrival, the royal couple was } \\
\text { married by the Papal Legate, Cardinal Sal- } \\
\text { viati. }{ }^{2} \\
\text { The celebration of the Emperor's wedding } \\
\text { was marred by two untoward events: the } \\
\text { death of his sister, the Queen of Denmark, }\end{array}$ \\
\hline & H I SPA N I N OTES \\
\hline
\end{tabular}




\section{I F E A N D W O R K S}

and the news of the murder of the Bishop of Zamora in the castle of Simancas, where he had been in confinement since the Comunidades. But during the stay in Seville there was at least one brilliant tournament, where the young Fernán Álvarez de Toledo and his uncle, Diego de Toledo, were especially distinguished for the gorgeousness of their trappings, covered with gold and silver and with tiny silver bells upon their steeds, and at which the Empress granted the prizes to those who had made the bravest show in the joust. ${ }^{1}$ On the very eve of the departure of the Court for Granada, Queen Germana once more became a bride, though she was more than fat and forty; this time the lucky man was Ferdinand of Aragon, Duke of Calabria. ${ }^{2}$ With her return to the regency of Valencia, Garcilaso lost another influential friend.

For the next six months the Court was established at Granada. To most of the members of the company this sojourn must have been, as it was to Navagero, a season of unmixed delight. To the cultured Venetian

\section{A N D MONOGRAPH S}




\begin{tabular}{|l|l|}
\hline GARCILASO DE LA VEGA \\
\hline $\begin{array}{l}\text { the gardens of the Generalife, with their flow- } \\
\text { ing streams and cool retreats, seemed to lack } \\
\text { but one thing: "some one to appreciate them } \\
\text { and enjoy them, living there in calm and } \\
\text { peace among his studies and the pleasures } \\
\text { that become a gentleman, without craving } \\
\text { for more." 1 We may form some idea of the } \\
\text { sort of things which he and the Spanish } \\
\text { courtiers discussed during their long, idle } \\
\text { days from the famous letter which Boscán } \\
\text { addressed to the Duchess of Soma as a } \\
\text { Prologue to his verses in the Italian style. } \\
\text { Often as the passage has been quoted, it } \\
\text { will bear repetition. "Being one day in } \\
\text { Granada with Navagero," he says, }{ }^{2} \\
\text { whom I have desired to name here to Your } \\
\text { Ladyship as one of the celebrated men of } \\
\text { our day, and discussing with him ques- } \\
\text { tions of talent and of letters, especially the } \\
\text { varieties of many languages, he asked me } \\
\text { why I did not try to write in Castilian, } \\
\text { sonnets and other forms of composition } \\
\text { used by the good authors in Italy; and } \\
\text { not only did he say it thus casually, but } \\
\text { he even urged me to do so. I departed }\end{array}$ \\
\hline H I S P A N I C N O T E S
\end{tabular}




\section{LIFE AND WORKS}

75

a few days later for my home; and along the long and lonely road, ruminating upon diverse matters I reverted many times to what Navagero had said to me; and so I began to try this type of verse. At first I found some difficulty in it, for it is exceeding artificial and has many peculiarities differing from ours. But afterwards fancying, perhaps with that love we have for things our own, that I was beginning to have some success, I found my interest in it warming little by little. But this would not have been enough to make me achieve great progress, if Garcilaso with his judgment, - which not only in my opinion, but in everyone's, must be looked upon as a guide, - had not confirmed me in my intent. And so, often times praising this my plan and finally approving it by his example, because he too decided to take this path, he at last made me occupy my idle moments in it more seriously. And when my judgment was opened by his persuasion, new reasons occurred to me each day to make me carry

\section{A N D MONOGRAPHS}




\begin{tabular}{|c|c|}
\hline 76 & GARCILASO DE LA VEGA \\
\hline & $\begin{array}{l}\text { on the undertaking which I had begun." } \\
\text { Such is the genesis of the Italian school } \\
\text { of poetry in Spain. Nowhere, probably, } \\
\text { in the whole history of literature is their } \\
\text { a more striking example of literary in- } \\
\text { fluence of one nation upon another thus } \\
\text { defnitely revealed. And if Boscán was } \\
\text { on terms of stuch intimacy with the Ve- } \\
\text { netian, we may assume that Garcilaso as } \\
\text { well came under his influence. Perhaps at } \\
\text { Granada, for the first time, they came to } \\
\text { appreciate Petrarch and his successors. } \\
\text { From Castiglione, too, whose Libro del } \\
\text { cortegiano was already becoming known in } \\
\text { mantiscripts in Italy, they must have } \\
\text { received encouragement in their efforts } \\
\text { to ennoble their native tongue, which they } \\
\text { had learned to admire and respect as boys } \\
\text { in school. We cannot begrudge the stay } \\
\text { of Charles V at Granada, though his ill- } \\
\text { fated palace destroyed much that could } \\
\text { never be replaced, for it gave to Spain a } \\
\text { new poetry. }\end{array}$ \\
\hline & H I SPAN I C NO.TE S \\
\hline
\end{tabular}




\section{IFE AND WORK S}

\section{CHAPTER VII}

\section{ISABEL FREIRE}

Concerning Garcilaso's life at Court during the next three years we have no information. There are a few personal documents, however, which reveal his financial prosperity. On the eve of his marriage, his brother, Francisco de la Vega, who had entered the church, had renounced his share of his father's estate and ceded it to Garcilaso; before his departure from Toledo for Seville, his mother had farored him with a third and a fifth of her estate as a reward for the "obedience and respect which he showed and the many services he had done and was doing every day." With these additions to his estate Garcilaso was able to purchase lands along the Tagus and on the IIth of March, $1_{5} 28$, he acquired for the sum of 550,000 maravedís a group of houses belonging to Antonio de Cepeda and Catalina de Arroyal. This property was situated in the parish of Santa Leocadia

\section{A N D M O N O G A P H S}




\begin{tabular}{|c|c|}
\hline 78 & GARCILASO DE LA VEGA \\
\hline & $\begin{array}{l}\text { on the Calle Real, just at the foot of the } \\
\text { slope on which his father's house stood; } \\
\text { his neighbors were his friend the Marquis } \\
\text { of Villafranca, Pedro de Toledo, and Juan } \\
\text { de Ayala. }{ }^{1} \text { 'The need of an establishment } \\
\text { of his own had become imperative, for his } \\
\text { wife Doña Elena had already given birth } \\
\text { to two sons, the elder called Garcilaso like } \\
\text { his father and his paternal grandfather, } \\
\text { the younger named Iñigo de Zúniga after } \\
\text { his maternal grandfather. During }{ }^{2}{ }^{28} \\
\text { another son was born who received the } \\
\text { name of Pedro de Guzmán. }{ }^{2} \text { Apparently } \\
\text { Garcilaso did not venture to give him his } \\
\text { brother's full name of Pedro Laso de la } \\
\text { Vega y de Guzmán, for Pedro Laso was } \\
\text { still distinctly unpopular with the Em- } \\
\text { peror, especially since his armed resistance } \\
\text { during the campaign in Navarre, when } \\
\text { Charles V had been forced to send troops } \\
\text { to seize his fortress of Los Arcos; }{ }^{3} \text { in fact } \\
\text { his situation and in particular his unremit- } \\
\text { ting efforts to secure pardon must have } \\
\text { been a by-word at the Court, for France- } \\
\text { sillo de Zunniga, in his whimsical Crónica, }\end{array}$ \\
\hline & H I SPA N I N N T E S \\
\hline
\end{tabular}




\section{LIFE AND WORKS}

swears by "Pedro Laso's hope for favor."1

There is, however, during these three years an episode in the life of Garcilaso which is of the greatest significance in his literary activity. Among the ladies who came from Portugal in 1526 in the train of Doña Isabella, there was one of such charm, according to Faria y Sousa, ${ }^{2}$ that the prospective bride declared that she would not depart for Castile, if she might not take her in her company. Doña Isabel Freire, for this was her name, had already inspired in the greatest of the Portuguese poets of his time, Francisco Sá de Miranda, a love which found such exuberant expression that it had brought upon the poet a decree of exile from the Court. ${ }^{3}$ That Garcilaso had every opportunity to become familiar with her and her charms is obvious from their residence together at Court during the next three years. Before Garcilaso left Spain in 1529, when the Emperor with his Court started for Italy, Dona Isabel was married to Antonio de Fonseca, lord of Toro. The exact date we

\section{A N D MONOGRAPH S}




\begin{tabular}{|c|c|}
\hline 80 & GARCILASO DE LA VEGA \\
\hline & $\begin{array}{l}\text { do not know; it must have been between } \\
\text { October, I528, and March, I } 529 \text {, for Luis } \\
\text { Zapata in his Miscelanea says that they } \\
\text { were married while the Court was at } \\
\text { Toledo, }{ }^{1} \text { and between the time of the Em- } \\
\text { peror's marriage and his departure for } \\
\text { Italy the Court was established at Toledo } \\
\text { only during these months. }{ }^{2} \text { The quintillas } \\
\text { which Garcilaso wrote commemorating this } \\
\text { marriage are the first of his verses to which } \\
\text { it is possible to assign a definite date, al- } \\
\text { though only recently has the connection } \\
\text { between them and the later poems been } \\
\text { made plain. } \\
\text { In the I } 574 \text { edition of his works, edited } \\
\text { by the learned Francisco Sánchez, "el } \\
\text { Brocense," appeared for the first time a } \\
\text { canción in Spanish meter, beginning "Culpa } \\
\text { deve ser quereros," which bore as its head- } \\
\text { ing: "Aviendose casado su dama." }{ }^{3} \text { This } \\
\text { was a vague inscription and might well } \\
\text { have referred to any youthful affair or } \\
\text { even to an imaginary disappointment. But } \\
\text { in a manuscript of the Gayangos collection, } \\
\text { now in the Biblioteca Nacional, }{ }^{4} \text { the verse }\end{array}$ \\
\hline & H I P A N I C NOTES \\
\hline
\end{tabular}




\section{I F E A N D WORK S}

has the following rubric: "A Dona Ysabel Freyra, porque se caso con un hombre fuera de su condicion." The phrase "fuera de su condicion" offers some difficulty; plainly it cannot be taken as referring to a difference in rank, for although Doña Isabel belonged to the house of the Dukes of Braganza, the house of Fonseca was one of the distinguished noble families of Spain and Don Antonio was later regidor of Toledo. ${ }^{1}$ It must then refer to some personal trait. The mere fact that Don Antonio was commonly known as "el Gordo" is not sufficient to explain the allusion; but in the first Eclogue of Garcilaso, where Salicio, - the poet in the role of the disappointed lover - exclaims,

Materia diste al mundo de esperança de alcançar lo impossible y no pensado $\mathrm{y}$ de hazer juntar lo differente, dando a quien diste el coraçon malvado... y con las simples aves sin roydo haran las bravas sierpes ya su nido; que mayor differencia comprehendo de ti al que as escogido,

\section{A N D MONOGRAPHS}




\begin{tabular}{|c|c|}
\hline 82 & GARCILASO DE LA VEGA \\
\hline & $\begin{array}{l}\text { it becomes clear that the incompatibility } \\
\text { was a spiritual one. This same feeling is } \\
\text { revealed by Sá de Miranda in the closing } \\
\text { lines of his gloss on the old song, } \\
\text { En toda la transmontana } \\
\text { nunca vi cosa mejor } \\
\text { que era la esposa de Anton, } \\
\text { vaquerizo de Morana, } \\
\text { written, as Braga has pointed out, }{ }^{2} \text { on the } \\
\text { news of Dona Isabel's marriage, when he } \\
\text { says, } \\
\quad \text { Que é isto que assi engana } \\
\quad \text { que sospira por Antão } \\
\quad \text { que não tem nada de humana. } \\
\text { Unfortunately we have very little in- } \\
\text { formation as to the real nature of the in- } \\
\text { timacy between Garcilaso and Isabel } \\
\text { Freire. That his affection for her was } \\
\text { intense and sincere we may be sure, with- } \\
\text { out the statement of Faria y Sousa, for } \\
\text { it is reflected in the intensity and sincerity } \\
\text { of every line which he wrote in memory }\end{array}$ \\
\hline & H I S A N I C NOTES \\
\hline
\end{tabular}




\section{LIF E A N D W O R K S}

of her. In the first Eclogue he has left a vague picture of the early days of their acquaintanceship, their happiness together and even their tender promises. But there is a passage in the second Eclogue which shows that the poet was not wholly proud of the rôle which he was playing. In the lines in which Nemoroso, - an older and wiser Garcilaso, - sings the praises of Severo, the preceptor of Fernán Álvarez de Toledo, as a physician for love-sick swains, he refers to his own experiences in such matters and recalls how Severo's advice had saved him from the folly and the danger of his ways and made him see

sin antojos delante, la vileza

de lo que antes ardiendo desseava. ${ }^{1}$

It is strange how this lady of Lusitania came into the lives of the two great poets of her day in the Peninsula, inspiring in them a devotion which lives on in their work. One cannot help wondering what were her charms that so enthralled them, if she was as slender and as golden-haired

\section{A N D M O N O R A P H S}




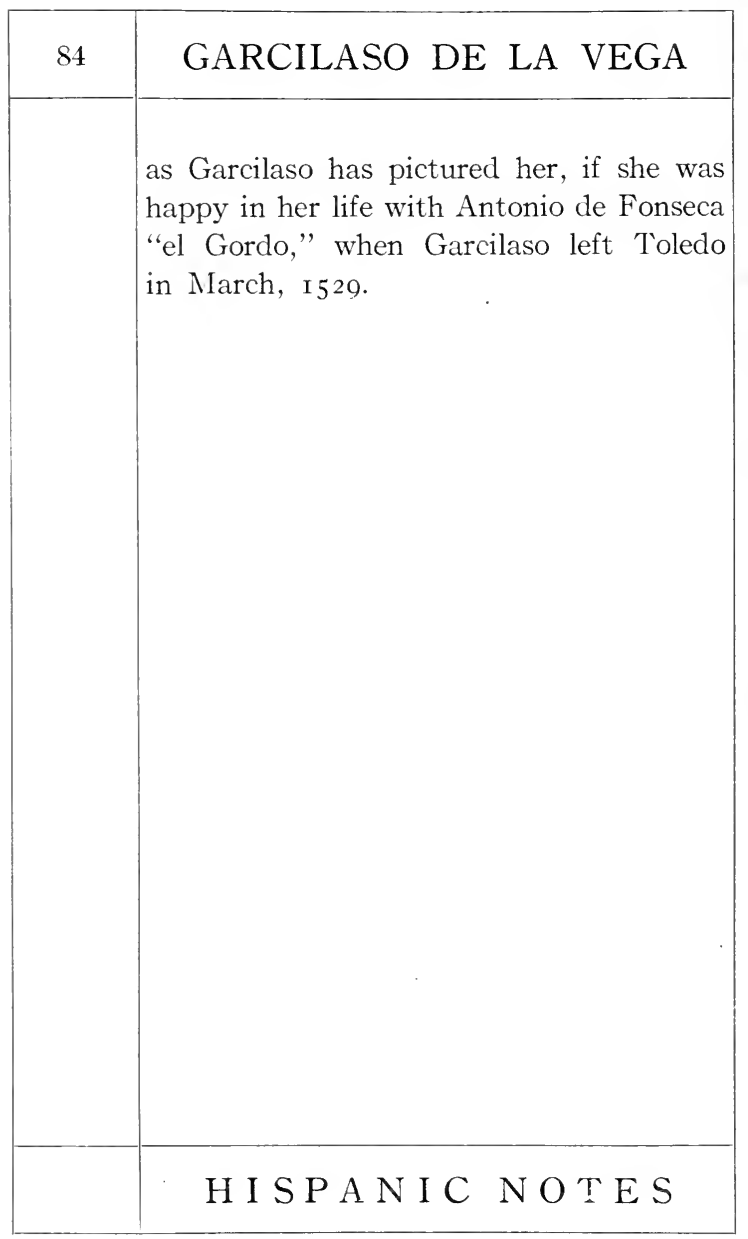




\section{LIFE AND WORKS}

\section{CHAPTER VIII}

\section{THE JOURNEY TO ITALY}

Charles $V$ had long been eager to visit Italy to receive the Imperial crown at the hands of the Pope, but his Castilian counsellors had been loath to have him depart before the birth of an heir to the throne. That hope had been realized in the birth of Philip at Valladolid in 1527 . Early in 1529 the Emperor determined to leave Spain, for the activity of the Lutherans in Germany and the menace of the Turks in Hungary made his personal presence a necessity for the preservation of the Empire. The Court started from Toledo on the gth of March; after a month in Saragossa, they reached Barcelona at the end of April. ${ }^{1}$ Three months passed before the fleet was ready to sail, for new ships were necessary to supplement those that the Emperor had already assembled and those that Andrea Doria brought to the city in June. At last, how-

\section{A N D MONOGRAPHS}




\begin{tabular}{|c|c|}
\hline 86 & GARCILASO DE LA VEGA \\
\hline & $\begin{array}{l}\text { ever, the arrangements were completed; } \\
\text { the flower of the nobility and the clergy } \\
\text { of Spain, several thousand infantry and } \\
\text { endless equipment and supplies were em- } \\
\text { barked. }{ }^{1} \\
\text { Two days before the fleet set sail, Gar- } \\
\text { cilaso drew up his last will and testament, } \\
\text { signed before a notary public on July 25, } \\
\text { I } 529 .^{2} \text { The witnesses to his signature were } \\
\text { his brother, Pedro Laso, his friend, Juan } \\
\text { Boscán, his servant Alonso de Salazar and } \\
\text { several others. The document, which has } \\
\text { happily been discovered and published by } \\
\text { the Marquis of Laurencín, is invaluable } \\
\text { in the glimpse that it offers of Garcilaso's } \\
\text { life, for it contains a memorial, drawn up } \\
\text { by Garcilaso himself, containing his per- } \\
\text { sonal disposition of his estate. By his } \\
\text { will, he named as his heir his son, Garcilaso } \\
\text { de la Vega, granting him the usual third } \\
\text { and fifth of the residue of his property and } \\
\text { providing with the customary formulae } \\
\text { for its transmission through the male line. } \\
\text { In the event of his death he named his } \\
\text { other sons, Iñigo de Zúniga and Pedro de }\end{array}$ \\
\hline & H I P A N I C N T E S \\
\hline
\end{tabular}




\section{LIFE A N D W O R K S}

Guzmán and any possible posthumous offspring as successive heirs; if none of of his children survived, his brother's oldest son, also named Garcilaso de la Vega, was to inherit the estate. The most interesting portion of the document is that in which he provided for his personal obligations. After the usual provision for masses for the repose of his soul and for relief for the orphans and needy - really needy, not beggars, he stipulates, - he orders that his body shall be buried in his grandmother's chapel in the church of San Pedro Mártir, ${ }^{1}$ unless he dies abroad, in which case they shall leave him wherever he is buried. He also gives specific orders that invitations to his funeral shall not be sent out and that no funeral sermon shall be delivered. His next thought is for his illegitimate son, Don Lorenzo, whom he wishes to be trained in the humanities at some good university, that he may enter the Church, if he shows an inclination for this career, or else may enter the law. There follows a list of his

\section{A N D M N O G R P H S}




\begin{tabular}{|c|c|}
\hline 88 & GARCILASO DE LA VEGA \\
\hline & $\begin{array}{l}\text { debts at the time. It is a strange succes- } \\
\text { sion of obligations: money borrowed from } \\
\text { friend and servants; money borrowed from } \\
\text { money lenders on the security of his wife's } \\
\text { dianonds or his mother's silverware; } \\
\text { money due to tradesmen and even to his } \\
\text { barber. As the Marquis of Laurencin has } \\
\text { pointed out, Garcilaso's financial condi- } \\
\text { tion is typical of his time; the Emperor } \\
\text { was not prompt in the payment of his } \\
\text { gentlemen's salaries: Garcilaso notes that } \\
\text { at the date of signing his will his wages } \\
\text { are some } 200 \text { ducats in arrears. But it } \\
\text { betokens how precarious was the financial } \\
\text { situation of his generation, when life was } \\
\text { conducted on credit. } \\
\text { Several of the items for which Garcilaso } \\
\text { provides show how scrupulous he must } \\
\text { have been in his sense of honor. Thus he } \\
\text { sets aside ten ducats to compensate a cer- } \\
\text { tain Martin of Navarre for a horse which } \\
\text { was taken from him by the French as a } \\
\text { result of some fault of Garcilaso's; and } \\
\text { since it is impracticable to pay him the } \\
\text { money, he suggests that the sum be ex- }\end{array}$ \\
\hline & H I S P N I C NOTES \\
\hline
\end{tabular}




\section{LIFE A N D WORKS}

pended for some pious purpose, or given to a sister of his page, Sacedo, who had died. Similarly he provided for restitution for damage he has caused, actual or possible, during the campaigns of Salvatierra and Fuenterrabía. The most interesting, and amusing, of these special bequests is one which concerns a certain Elvira; it is worth giving in his own words: "I think that I am under obligations to a girl for her honor; her name is Elrira, I think that she lives in La Torre or Almendral, towns in Extremadura. My brother, Don Francisco, or Bariana, who was formerly chatelain of Los Arcos or his wife, Parra, know her; they will say who she is; send some honest, reliable person there to find out from her, whether I am under the aforesaid obligation, and if it proves to be that I am, give her Io,000 maravedis; and if she is married, great care must be exercised in the matter lest her honor be affected and she be endangered."

It is plain that Garcilaso did not count Elvira's honor dear; the sum he offers her

\section{A N D MONOGRAPHS}




\begin{tabular}{|c|c|}
\hline 90 & GARCILASO DE LA VEGA \\
\hline & $\begin{array}{l}\text { was a mere trifle, perhaps I } 50 \text { pesetas in } \\
\text { our own day, for he left his barber, Juan } \\
\text { de Madrid, } 4, \text { oo maravedís to pay for the } \\
\text { few times he had shaved him without } \\
\text { receiving his pay. But his solicitude for } \\
\text { her welfare and his readiness to assume the } \\
\text { obligation cannot fail to add to our respect } \\
\text { for him and for his sense of personal honor. } \\
\text { If he showed such concern for this country } \\
\text { girl, merely upon suspicion of his obliga- } \\
\text { tion, we may feel sure that he had already } \\
\text { made liberal provision for the mother of } \\
\text { Don Lorenzo, whoever she may have been. } \\
\text { It was the } 27 \text { th of July when the fleet } \\
\text { of Charles V sailed from Barcelona, some } \\
\text { thirty galleons, with carracks and lighter } \\
\text { craft making about a hundred ships. It } \\
\text { was the first event in the reign of the Em- } \\
\text { peror when his Spanish subjects had had } \\
\text { the opportunity of displaying their dignity } \\
\text { to the rest of Europe; they had gathered } \\
\text { in unusual numbers, so that there were } \\
\text { said to have been no less than five thousand } \\
\text { nobles in the company. Sandoval relates } \\
\text { that on the eve of his embarcation, Charles }\end{array}$ \\
\hline & H I S A N I C NOTES \\
\hline
\end{tabular}




\section{IFE A N D WORK S}

$\mathrm{V}$ had been forced to cut off his long hair, because he was suffering from some affection of the scalp, and that the whole Court was forced to follow his example. ${ }^{1} \mathrm{He}$ does not tell us whether Garcilaso was one of those who wept at this Imperial mandate. But it is interesting to note that from this time on closely cropped heads became the fashion. It is apparently at this time that the habit of wearing a beard was introduced into Spain, for in the portrait of the Emperor which is found in a contemporary print $^{2}$ he is represented as wearing a scraggly beard and all of his later portraits as well as those of his Spanish contemporaries show that the beard had become the rule. Garcilaso's mention of the barber who shaved him makes it plain that he, at least, had not up to this time worn a beard; the only likeness which we have of him, made after his death, is heavily bearded; so that we may reasonably assume that this is the moment, when so far as facial ornament is concerned, the Middle Ages gave place to the Renaissance in Spain.

\section{A N D M O N O R A P H S}




\begin{tabular}{|c|c|}
\hline 92 & GARCILASO DE LA VEGA \\
\hline & $\begin{array}{l}\text { Following the coast, the fleet reached } \\
\text { Genoa on August I } 2 \text { th. }{ }^{1} \text { In the city } \\
\text { of Doria they were accorded an enthusi- } \\
\text { astic reception; such was the press of } \\
\text { citizens which thronged to the pier to wit- } \\
\text { ness them disembarking that many were } \\
\text { drowned. It had been the intention of the } \\
\text { Emperor to proceed to Naples and, up- } \\
\text { on his return to Rome, to receive the } \\
\text { Imperial crown from the Pope, with whom } \\
\text { he had just concluded a peace (Barcelona, } \\
\text { June } 29 \text {, I } 529 \text { ). }{ }^{2} \text { But before he left Pia- } \\
\text { cenza he received from his brother Fer- } \\
\text { dinand, king of Hungary, messages inform- } \\
\text { ing him of the invasion of the kingdom by } \\
\text { the Turks and urging his immediate assist- } \\
\text { ance. }{ }^{3} \text { Under these. circumstances Charles } \\
\text { V determined to postpone his visit to his } \\
\text { Neapolitan possessions and arranged with } \\
\text { Clement VII to have the ceremonial of } \\
\text { the coronation performed at Bologna. The } \\
\text { Pope reached there on October } 24 \text { th and } \\
\text { on the } 5 \text { th of November Charles entered } \\
\text { the city. } \\
\text { The task of settling the affairs of Italy }\end{array}$ \\
\hline & H I S A N I C NOTES \\
\hline
\end{tabular}




\section{I F E A N W O R K}

proved to be a long and difficult one. But not all the time was spent in these arduous diplomatic negotiations. The nobles of the Court found ample time to enjoy the hospitality of the city and in turn to entertain their hosts; thus on December I 2 th the Spaniards revealed to Italian eyes for the first time the splendor and the prowess of their native juego de cañas, dazzling the assembled throng of ambassadors with their dashing evolutions and their gaudy costumes of yellow, crimson and black. ${ }^{1}$ These months must have proved a period of revelation to Garcilaso. There had gathered in Bologna representatives of every state in Italy, among them its intellectual as well as its political leaders. For the first time he was able to familiarize himself with the Tuscan tongue and what is of far greater importance, with Tuscan literature, of which he had already had some glimpse through Navagero and Castiglione. It is undoubtedly to the stimulus of this visit in Italy that we owe his con-

\section{A N D MONOGR A P H S}




\begin{tabular}{|c|c|}
\hline 94 & GARCILASO DE LA VEGA \\
\hline & $\begin{array}{l}\text { version to the Italian style; its fruits will } \\
\text { soon be evident. } \\
\text { When the conflicting claims of each } \\
\text { Italian community had at last been ad- } \\
\text { justed, when Milanese, Venetians, and the } \\
\text { Papacy had been alligned in a new adjust- } \\
\text { ment, with only the seething question of } \\
\text { Florence left to disturb the balance, the } \\
\text { Emperor hastened to complete his Italian } \\
\text { tour by assuming the visible symbol of his } \\
\text { power, the Imperial crown. On February } \\
22 \text { nd the iron crown of Lombardy was } \\
\text { placed upon his head. }{ }^{1} \text { Two days later, } \\
\text { upon his thirtieth birthday, he was crowned } \\
\text { with the crown of Charlemagne in the } \\
\text { Cathedral of San Petronio. The splendor } \\
\text { of the ceremony surpassed that of any of } \\
\text { his previous public appearances. And it } \\
\text { is noteworthy that those who bore the } \\
\text { chief part in the various acts were, with } \\
\text { a few exceptions, his Spanish courtiers. } \\
\text { Among these Pedro de Toledo, who acted } \\
\text { as the representative of the house of the } \\
\text { Dukes of Alba during the Imperial visita- } \\
\text { tion, was one of the most distinguished. } \\
\text {. }\end{array}$ \\
\hline & H I SPANIC NOTES \\
\hline
\end{tabular}




\section{LIFE A N D W O R S}

It was he who held the scabbard of the sword, at the ceremony on February 2oth while the Pope presented the blade to the Emperor; ${ }^{1}$ in the solemn procession which concluded the ceremony of the Imperial coronation he rode beside Andrea Doria almost at the head of the line. ${ }^{2}$ We may fancy that Garcilaso was numbered among the knights who rode behind him, so gallantly arrayed in crimson velvet caps and cloaks.

It was almost a month before Charles $\mathrm{V}$ left Bologna for Germany. The greater part of his Spanish followers had been granted permission to return to their homes; their presence would have been more of a detriment than an assistance in settling the religious problems which faced him beyond the Alps. At Mantua, on the I 7 th of April before his departure for Innsbruck, he issued an order granting Garcilaso release from service in his household, with an annuity of 80,000 maravedís and the privilege of returning to Spain. ${ }^{3} \quad$ The cédula which accords this permission men-

\section{A N D MONOGRAPHS}




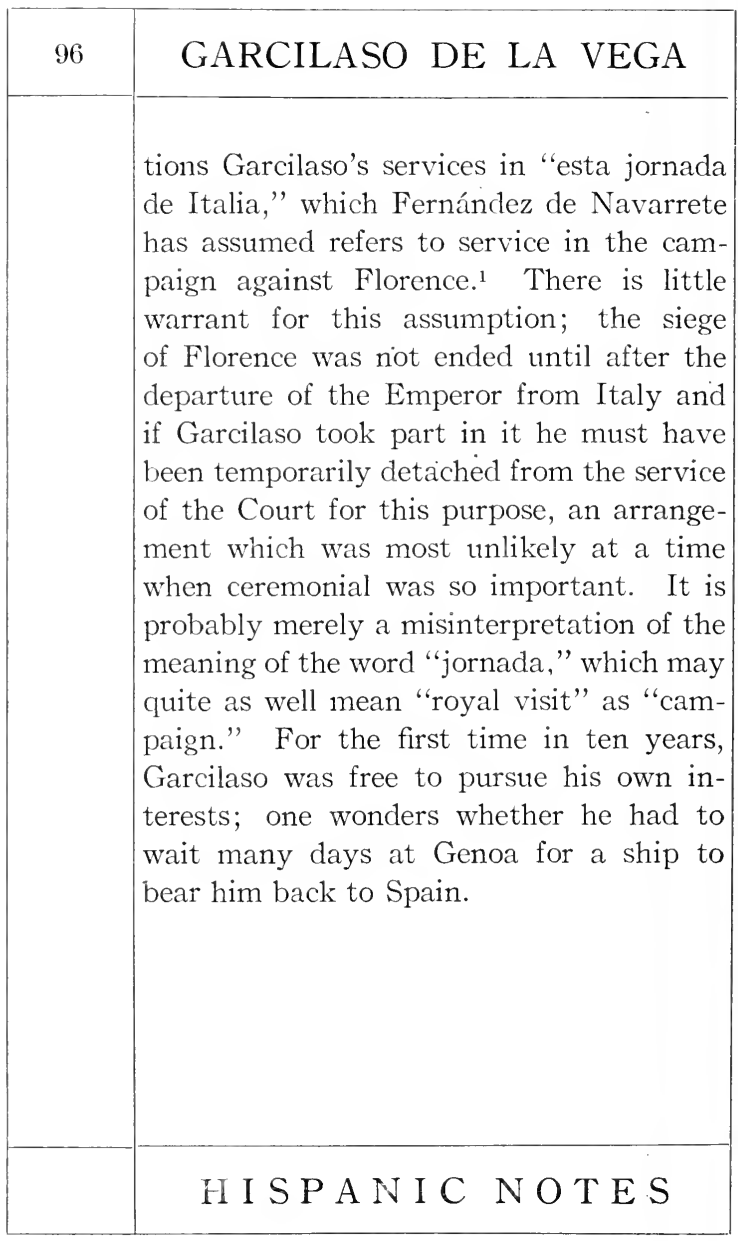




\section{LIFE A N D W ORK S}

\section{CHAPTER IX}

\section{A MISSION IN FRANCE}

The rest from service which he had promised himself was not destined to be long. There are certain burdens incident to popularity; within a few months the Empress remembered that he was exactly the man to fulfill for her a mission requiring some address and tact. While Charles $\mathrm{V}$ was on his way to Italy, he had received at Savona the news that his aunt, Marguerite, and the Dowager Queen of France had signed a peace treaty at Cambray on August 5th. ${ }^{1}$ One of the stipulations of this treaty, renewing those of the treaty of Madrid of four years before, provided for the completion of the projected marriage between Francis I and Eleanor of Austria. The sovereigns concerned having ratified the terms of the treaty, Eleanor had once more started for France together with the two French Princes who had been

\section{A N D MONOGRAPHS}




\begin{tabular}{|l|l|}
\hline 98. & GARCILASO DE LA VEGA \\
\hline held during these years as hostages. Elabo- \\
rate precautions were taken by both the \\
French and the Spaniards to insure that \\
there be no trickery in meeting the terms \\
of the transfer. Every ducat which the \\
French envoys offered in payment of the \\
sum which Francis I had agreed to give \\
was weighed and tested by specialists be- \\
fore the Spaniards would allow the little \\
boat which carried the Queen and the \\
Princes to cross the Bidasoa to the French \\
shore. It was late at night on July I, \\
I530 before they were on French soil; on \\
the following day, accompanied by Anne \\
de Montmorency, Marshall of France, \\
they entered Bayonne. Francis I, who \\
had come to Bordeaux to await them, now \\
started to meet the company. On July \\
th, he was married to Doña Eleanor at \\
the Abbay of Beyries near Mont-de-Mar- \\
san. Five days later the royal couple and \\
the young princes were enthusiastically \\
welcomed in Bordeaux. \\
Queen Eleanor was deeply gratified at \\
the cordiality of her reception and at the \\
\hline H I S P A N I C N O T E S \\
\hline
\end{tabular}




\section{I F E A N D W OR K}

tenderness of her royal husband; her letters to her brother and to her sister-in-law revealed her satisfaction. ${ }^{1}$ Charles $\mathrm{V}$ was himself none the less pleased; from Augsburg he wrote to his wife on July 3 Ist, telling her the good news and urging that a messenger be sent at once to congratulate the new Queen. ${ }^{2}$ It was then that the Empress thought of Garcilaso. Her choice was a happy one, as Fernández de Navarrete has remarked, for Garcilaso must have been on terms of intimacy with Queen Eleanor, if for no other reason than the circumstance that his wife had been one of her ladies-in-waiting. On August I6th she wrote to the Emperor that she had arranged to send Garcilaso to visit her, adding, with a shrewdness which characterized most of her actions (this part in cipher), that this would furthermore be an excellent opportunity to secure from the Imperial ambassadors information concerning the status quo in France and also, in passing, to observe what steps were being taken along the frontier, however

\section{A N D M O N G R A P H S}




\begin{tabular}{|c|c|}
\hline 100 & GARCILASO DE LA VEGA \\
\hline & $\begin{array}{l}\text { distant might be the prospect of war. }{ }^{1} \text { To } \\
\text { defray the expenses of the trip, five hun- } \\
\text { dred ducats were promptly granted (Aug- } \\
\text { ust } 2 \text { Ist) and Garcilaso started on his first } \\
\text { diplomatic mission. } \\
\text { We do not know whether he proved him- } \\
\text { self a worthy son of his father as the repre- } \\
\text { sentative of his sovereign; the contem- } \\
\text { porary records of his own country and of } \\
\text { France are silent on the details of this } \\
\text { visit. Francis I and his bride, together } \\
\text { with their Court had started for Paris, by } \\
\text { way of the valley of the Loire. They had } \\
\text { made their royal entry into Angoulleme on } \\
\text { July } 24 \text { th; passing through Cognac, } \\
\text { Saint Jean d'Angely and Chenonceau they } \\
\text { reached the chateau of Amboise at the end } \\
\text { of September and there spent the month } \\
\text { of October. The first weeks of November } \\
\text { they were at the chateau of Blois; then by } \\
\text { easy stages they journeyed to Chambord } \\
\text { and Orléans, arriving at Fontainebleau } \\
\text { early in December. Garcilaso must have } \\
\text { overtaken the Court before they reached } \\
\text { Amboise and he no doubt accompanied }\end{array}$ \\
\hline & H I P A N I NOTES \\
\hline
\end{tabular}




\section{LIFE A N D WORKS}

101

them at least for a time. It would be interesting to have some account of the impressions which this visit must have made on the young Spaniard. Francis I was an enthusiastic patron of the arts and he had surrounded himself with a company of Italians who were engaged in the creation of works of beauty for his delight. It is possible that Garcilaso met at this time Luigi Alamanni, the Florentine poet who had a second time taken refuge with Francis I, joining the Court at Angoûleme on July 3 oth. ${ }^{1}$ At least we may be sure that the culture and the love of letters which marked that Court stirred deeply the Toledan visitor who had already begun to feel the power of the current of Italian learning and artistic progress.

Early in I53I Garcilaso must have been back in Spain, bearing the reports desired by the Empress. On April 17 th he was in Toledo, and signed his consent to the transfer of the estate of Los Arcos to his brother Pedro Laso. ${ }^{2}$ This property, which had been seized by the Emperor as a result

\section{A N D MONOGRAPHS}




\begin{tabular}{|c|c|}
\hline 102 & GARCILASO DE LA VEGA \\
\hline & $\begin{array}{l}\text { of Don Pedro's resistance, had been bought } \\
\text { back by his mother for the sum of } 6,000 \\
\text { ducats, who now proceeded to restore it } \\
\text { to him as a portion of his inheritance. } \\
\text { Fernández de Navarrete states that Gar- } \\
\text { cilaso was in Italy in I53I, }{ }^{1} \text { but this state- } \\
\text { ment is based once more upon a misinter- } \\
\text { pretation of the word "jornada." The } \\
\text { authority upon which he relies says merely, } \\
\text { "In I } 53 \text { I it appears that he was in the } \\
\text { 'jornada de Italia' and requests an office } \\
\text { in Toledo." } 2 \text { This plainly refers to his } \\
\text { part in the Imperial visit; he is basing his } \\
\text { claim for appointment upon the services } \\
\text { which he then rendered. Whether he re- } \\
\text { ceived this office or not, we do not know. } \\
\text { But in August of the same year he was in } \\
\text { Ávila, acting as a witness at the betrothal } \\
\text { of his nephew, Garcilaso de la Vega, to } \\
\text { Doña Isabel de la Cueva, daughter of Juan } \\
\text { de la Cueva and Doña Mencía de Bazán } \\
\text { and heiress to the duchy of Alburquerque. } \\
\text { He was soon to have cause to rue his share } \\
\text { in this alliance. }\end{array}$ \\
\hline & H I S P A I C NOTES \\
\hline
\end{tabular}




\section{LIFE A N D WORK S}

\section{CHAPTER X}

\section{IMPERIAL DISFAYOR}

Charles V spent the year I53 I in Flanders. At the end of the year he received from his brother Ferdinand news that filled him with misgiving: the Turks were again preparing to invade Austria. $\mathrm{He}$ at once dispatched messages to his several possesssions calling upon them for assistance in this war against the Infidels. ${ }^{1} \mathrm{His}$ letter to the Empress reached Spain late in January. Almost the first to answer the call was Fernán Álvarez de Toledo who had just inherited the duchy of Alba by the death of his grandfather, Fadrique de Toledo, in September, 1531 ; $^{2}$ with Garcilaso among his followers he at once started to join the Emperor at Bruxelles. They had reached the little Basque town of Tolosa in Guipúzcoa on February 3rd, when there came an unexpected delay.

The Duke of Alburquerque and the other members of the house of Cueva at

\section{A N D M O N O R A P H S}




\begin{tabular}{|l|l|}
\hline 104 & $\begin{array}{l}\text { GARC ILASO DE LA VEGA } \\
\text { the Court of Charles V had learned during } \\
\text { the summer of the marriage which Dona } \\
\text { Mencía Bazán was arranging for her daugh- } \\
\text { ter. The prospect of an alliance between } \\
\text { their family and that of Pedro Laso was } \\
\text { extremely distasteful; it meant little less } \\
\text { than ruin, for Pedro Laso, in spite of his } \\
\text { pardon, had never recovered from the } \\
\text { stigma attached to his participation in } \\
\text { the Comunidades. At their instigation, } \\
\text { Charles V had written on September 4th } \\
\text { to his wife and to the Archbishop of San- } \\
\text { tiago, urging upon them the need of pre- } \\
\text { venting this union. }{ }^{1} \text { But his action was } \\
\text { too late, for as we have seen, the betrothal } \\
\text { had taken place on the I th of August. } \\
\text { Too late for an ordinary individual, but } \\
\text { not too late for an absolute sovereign. The } \\
\text { Empress discovered upon investigation } \\
\text { that Garcilaso had been present at the } \\
\text { ceremony and on January 3o, I 532 she } \\
\text { issued a general order to the corregidores } \\
\text { of the realm to apprehend Garcilaso, where- } \\
\text { ever he might he found, and secure from } \\
\text { him a deposition under oath in answer to }\end{array}$ \\
\hline H I S P A N I C N O T E S \\
\hline
\end{tabular}




\section{IFE A N D WORK S}

a series of questions concerning his share in the ceremony of the betrothal. At the same time she granted him in the name of the Emperor the right to take oath - a privilege which all knights of the Order of Santiago must first receive from the Grand Master. A faithful official of Azcoitia, on receipt of Her Majesty's command, learning that Garcilaso would reach the nearby town of Tolosa on February 3 rd, hastened thither and found him at the inn at which the Duke of Alba was staying.

Informed of the order, Garcilaso expressed his willingness to answer the questions. His acquaintance with the parties involved and his knowledge that a marriage had been contracted between the mother of Doña Isabel and his brother he readily confessed. But regarding the betrothal his answers were distinctly evasive; all that he would say was that nothing had been done since the arrival of the Emperor's orders. Once more questioned as to whether there had been a betrothal and whether he had been personally pre-

\section{A N D M O N G R A P H S}




\begin{tabular}{|c|c|}
\hline 106 & GARCILASO DE LA VEGA \\
\hline & $\begin{array}{l}\text { sent, he repeated his former irrelevant } \\
\text { answer. Thereupon the corregidor pro- } \\
\text { duced an order from the Empress com- } \\
\text { missioning him to hold Garcilaso for further } \\
\text { instructions, in case he should prove to } \\
\text { have had any part in the affair. Garcilaso } \\
\text { protested against this, arguing that noth- } \\
\text { ing had been proved and that he must be } \\
\text { about the King's business. But the co- } \\
\text { rregidor was a trustworthy servant; he } \\
\text { would lend no ear to his quibbles, alleging } \\
\text { that his reputation as an examiner was } \\
\text { at stake, } \\
\text { The Empress was highly indignant at } \\
\text { Garci'aso's refusal to answer her ques- } \\
\text { tions and suspecting that he had acted } \\
\text { thus because of a consciousness of the } \\
\text { moral support of the Duke of Alba, called } \\
\text { the latter sharply to task in her letter to } \\
\text { the corregidor. In this letter she bade her } \\
\text { official once more to put the questions di- } \\
\text { rectly to Garcilaso and if he should admit } \\
\text { to any share in the affair, to exile him } \\
\text { from the realm and from the Emperor's } \\
\text { Court, under penalty of loss of title and }\end{array}$ \\
\hline & H I P A N I C N T E S \\
\hline
\end{tabular}




\section{LIFE A N D WORKS}

estate. In case he should have the presumption still to refuse specific answers to her specific questions - an inconceivable disobedience - , he was to be placed under arrest and sent to the fortress of Salvatierra. Garcilaso, who perceived that his device for escaping from Spain was unsuccessful, now deposed that thus far he had spoken the truth, but not the whole truth; what remained was this. Some time in August of the preceding year one day after dinner - just what day of the month he could not recall - a page had come to the house where he was in Avila and told him that somebody wanted him. And so he went to the Cathedral and there, in the cloister, he found Dona Isabel accompanied by her dueña, his own nephew, a priest, and two men, named Simancas and Fonseca. $\mathrm{He}$ was of the opinion that afterward in one of the chapels, Doña Isabel and his nephew had taken hands before the priest. Upon closer questioning he deposed that the dueña's name was María de Olío and that of the

\section{A N D MONOGR A P H S}




\begin{tabular}{|c|c|}
\hline 108 & GARCILASO DE LA VEGA \\
\hline & $\begin{array}{l}\text { two men, Simancas was his nephew's } \\
\text { tutor and Fonseca, a servant of Doña } \\
\text { Mencia; that he was certain that the } \\
\text { couple held hands; that he did not know } \\
\text { the name of the priest; that no one else } \\
\text { was present. After this tardy confession } \\
\text { had been dragged from him, Garcilaso } \\
\text { once more volunteered the information that } \\
\text { nothing had been done since the arrival of } \\
\text { the Emperor's order. The corregidor at } \\
\text { once pronounced sentence of banishment, } \\
\text { in accordance with his instructions. } \\
\text { Garcilaso's role during this investiga- } \\
\text { tion does not reflect greatly to his credit. } \\
\text { But it must be remembered that he was } \\
\text { doubtlessly honest in his assertion that } \\
\text { his own share in the affair was over before } \\
\text { he was aware of the Emperor's disap- } \\
\text { proval and that he had at no time acted } \\
\text { in defiance of his commands. We must } \\
\text { remember, too, - as he no doubt remem- } \\
\text { bered, - that the Emperor was unfor- } \\
\text { giving when he was once offended and he } \\
\text { naturally was loath to make any admission } \\
\text { which would bring down upon him the dis- }\end{array}$ \\
\hline & H I P A N I N N T E S \\
\hline
\end{tabular}




\section{LIFE AND WORKS}

pleasure which his brother had so long suffered. Finally there can be little question that his course was the result of the suggestions of the Duke of Alba, for as soon as his sentence was pronounced the latter wrote to the Empress, asking her to release Garcilaso from his penalty and declaring that he would not proceed to Flanders without him. In the face of Isabella's refusal to grant his request, he took the matter into his own hands; with Garcilaso in his suite he started across the Pyrenees.

Of this journey Garcilaso has left a description in a passage of the second Eclogue, beginning

\section{Los montes Pireneos...}

en medio del invierno atravesava. ${ }^{1}$

Once through the difficulties of winter in the mountain passes, Fernando received orders from the Emperor to hasten his steps. Leaving the rest of his company to follow at a slower pace, he and Garcilaso hurried north, changing horses from

\section{A N D MONOGRAPHS}




\begin{tabular}{|l|l|}
\hline 110 & $\begin{array}{l}\text { GARCILASO DE LA VEGA } \\
\text { town to town. At Paris the Duke was } \\
\text { detained by a brief illness. His recovery } \\
\text { was prompt and they pushed on. When } \\
\text { they reached Flanders, the Emperor and } \\
\text { his Court had already started for Ratis- } \\
\text { bonne. Apparently they continued to } \\
\text { Utrecht (Traiectum ad Rhenum) for Gar- } \\
\text { cilaso writes that their journey brought } \\
\text { them "al pasaje del gran Rheno." It is } \\
\text { interesting that his first glimpse of the } \\
\text { Rhine recalled to his mind the passage in } \\
\text { Caesar which he had learned as a boy and } \\
\text { he fancied that it was here that the Roman } \\
\text { leader had crossed into German territory. } \\
\text { From Utrecht they took passage by boat } \\
\text { up the Rhine to Cologne. There Garcilaso } \\
\text { seems to have seen the old pictures in the } \\
\text { church of St. Ursula, for he writes, } \\
\text { Ursula, desposada y virgen pura, } \\
\text { mostrava su figura, en una pieça } \\
\text { pintada su cabeça. Alli se via } \\
\text { que los ojos bolvia ya espirando } \\
\text { y estavate mirando aquel tirano } \\
\text { que con acerba mano llevo a hecho } \\
\text { de tierno en tierno pecho tu compana. }\end{array}$ \\
\hline H I S P A N I C N O T E S
\end{tabular}




\section{LIFE A N D W R K S}

It is not plain whether the rest of their trip "por la fiera Alemaña" was made up the Rhine or on horseback. The latter part was down the Danube, probably from the town of Ulm. Late in March they reached Ratisbonne.

Garcilaso's first thought was to secure restoration to the Emperor's favor. His friend, the Marquis of Villafranca, whose influence with Charles $V$ was great, presented to the Emperor a memorial from Garcilaso, protesting against the sentence passed upon him. ${ }^{1}$ But the Empress had informed her husband of the circumstances of the case and he was little inclined tc show mercy. Orders were issued on March $24_{\text {th }}$ that Dona Isabel should be sent to the convent of Madrigal, that the younger Garcilaso, who had fled to Portugal, should be prosecuted ${ }^{2}$ and that Garcilaso the suppliant should be confined on an island in the Danube. Fernández de Navarrete has advanced the suggestion ${ }^{3}$ that the island in question was that of Schutt, near Pressburg. Such an opinion is, however,

\section{A ND MONOGRAPH S}




\begin{tabular}{|c|c|}
\hline 112 & GARCILASO DE LA VEGA \\
\hline & $\begin{array}{l}\text { absolutely untenable. Pressburg is over } \\
\text { four hundred miles from Ratisbonne, and } \\
\text { Charles V remained in the latter city un- } \\
\text { til the first of September. It is much } \\
\text { more natural, and easy, to believe that } \\
\text { his place of confinement was one of the } \\
\text { several islands in the Danube near Ratis- } \\
\text { bonne. It was during this imprisonment } \\
\text { that Garcilaso wrote the first of his verses } \\
\text { in the Italian style to which it is possible } \\
\text { to assign a date, the Canción which be- } \\
\text { gins, } \\
\text { Con un manso ruido } \\
\text { de agua corriente y clara } \\
\text { cerca el Danubio una isla, que pudiera } \\
\text { ser lugar escogido } \\
\text { para que descansara } \\
\text { quien como yo esto agora no estuviera. } \\
\text { How bitter was the disappointment which } \\
\text { this first evidence of Imperial disfavor } \\
\text { brought to Garcilaso is revealed in every } \\
\text { line of the poem and not the least of the } \\
\text { poignancy came from the realization that } \\
\text { the fault was largely his own. }\end{array}$ \\
\hline & H I P A N I C NOTES \\
\hline
\end{tabular}




\section{IFE AND W ORK S}

Aqui estuve yo puesto,

o por mejor dezillo,

preso, forçado, y solo en tierra agena.

Bien pueden hazer esto

en quien puede sufrillo

$\mathrm{y}$ en quien el a si mismo se condena.

Here and in several of his sonnets, ${ }^{1}$ which were probably written at the same period, he laments the sudden turn of Fortune's wheel,

pues a sido en un ora
todo aquello deshecho
en que toda mi vida fue gastada.

From this moment on, his whole life was spent in the effort to recover his place of favor with the Emperor.

Meanwhile his friends had not forgotten him. On the $25^{\text {th }}$ of June the Council issued an order, stating that since he confessed his guilt and begged for mercy, he should be sent to a convent (presumably that of his Order at Uclés), to Africa, to the fleet, to Naples, or should be allowed to take part in the coming campaign

\section{A N D MONOGRAPHS}




\begin{tabular}{|c|c|}
\hline 114 & GARCILASO DE LA VEGA \\
\hline & $\begin{array}{l}\text { against the Turks, remaining in confine- } \\
\text { ment until the army started for Austria. }{ }^{1} \\
\text { At the end of the order His Majesty is } \\
\text { reminded of the insistency with which the } \\
\text { Duke of Alba urged this action. After } \\
\text { consultation the Imperial Secretary, Cobos, } \\
\text { noted on the margin that Naples or a con- } \\
\text { vent would be the best solution. Just at } \\
\text { this juncture, the Marquis of Villafranca, } \\
\text { Pedro de Toledo, was named Viceroy of } \\
\text { Naples (before July I Ith); on August } 3 \text { rd } \\
\text { he left Ratisbonne by post; a week later } \\
\text { he was in Verona. The last ten days of } \\
\text { August he spent in Rome as a guest of the } \\
\text { Pope, Clement VII. He entered Naples } \\
\text { on September } 5 \text { th. }{ }^{2} \\
\text { Since the publication of Fernández de } \\
\text { Navarrete's Life of Garcilaso it has been } \\
\text { generally accepted that the poet accom- } \\
\text { panied Pedro de Toledo at this time. }{ }^{3} \text { It } \\
\text { is difficult however to determine with cer- } \\
\text { tainty his whereabouts during the next } \\
\text { few months. Herrera states that he took } \\
\text { part in the campaign against Solyman } \\
\text { and the early biographers followed his }\end{array}$ \\
\hline & H I S P A I C NOTES \\
\hline
\end{tabular}




\section{LIFE AND W ORKS}

statement. ${ }^{1}$ The detailed description of the Duke of Alba's part in this campaign which Garcilaso gives in the second Eclogue ${ }^{2}$ lends some color to this theory, but we must not give too much weight to this argument, for the same process might be used to prove that he was also present at the battle of Gelves in 1510 , of which he has left a vivid account in the same Eclogue. The situation is further complicated by the fact that in a list of Spanish gentlemen who passed through Treviso, Italy on October 22,1532 , on their way to Venice, there appears immediately after the name of the Duke of Alba a certain "Don Gratia di Vega." 3 It is of course possible that this García de Tega has no connection with Garcilaso de la Vega, yet seeing this name so closely connected with that of his protector, and knowing that Diego de Toledo was also in the company. one is tempted to believe that the Duke had succeeded in persuading the Emperor to allow Garcilaso to postpone his departure for Naples until the end of the cam-

\section{A N D MONOGRAPHS}




\begin{tabular}{|c|c|}
\hline 116 & GARCILASO DE LA VEGA \\
\hline & $\begin{array}{l}\text { paign. There remains still another pos- } \\
\text { sibility: the Duke may have once more } \\
\text { ventured to disregard his sovereign's } \\
\text { orders and retained Garcilaso in his com- } \\
\text { pany without the Emperor's knowledge. } \\
\text { For this there is some warrant in the fact } \\
\text { that Garcilaso has left unmentioned pre- } \\
\text { cisely this portion of the Duke's career } \\
\text { in the description which we have several } \\
\text { times referred to. If he had accompanied } \\
\text { him in defiance of the Emperor's orders, } \\
\text { he could ill afford to show too intimate a } \\
\text { knowledge of this trip from Vienna to } \\
\text { Italy. Whatever conclusion we may draw, } \\
\text { - and the matter is not a vital one, - } \\
\text { we know that Garcilaso was in Naples in } \\
\text { November, when he bought a horse, or } \\
\text { rather, had a horse charged to his account, } \\
\text { as a lieutenant of the Viceroy of Naples. }\end{array}$ \\
\hline & H I S A N I C N OTES \\
\hline
\end{tabular}




\section{IF E A N D W ORK S}

\section{CHAPTER XI \\ EXILE IN NAPLES}

Garcilaso's exile in Naples, for his residence there was virtually exile, brings us to the most important period of his life. His close relations with the newly appointed Viceroy insured his immediate admittance into the literary circle which made Naples its centre; the acquaintances which he formed were to influence largely the course which his own literary endeavors followed from this time. While in general the Neapolitan Humanists had devoted most of their efforts to attaining a mastery of Latin as an instrument of artistic composition, they had not neglected the tasks of erudition. The Accademia Pontoniana, faithful to the traditions established by its founder, had continued to meet in the villa of Sannazaro. Since the death of the latter in 1530 , the gatherings had been held in the house of Scipione Capece, a

\section{A N D MONOGRAPH S}




\begin{tabular}{|c|c|}
\hline 118 & GARCILASO DE LA VEGA \\
\hline & $\begin{array}{l}\text { learned lawyer and professor in the Uni- } \\
\text { versity of Naples, whose Latin poems, in } \\
\text { particular the De principiis rerum, found } \\
\text { favor in the sight of Pietro Bembo. } \\
\text { Among the members of the Accademia } \\
\text { during Garcilaso's residence in Naples } \\
\text { were Antonio Epicuro, author of the } \\
\text { Dialogo di tre ciechi, Bernardino Martirano, } \\
\text { Imperial secretary at Naples, Antonio } \\
\text { Minturno, poet and critic of poetry, and } \\
\text { Girolamo Seripando, at the time Arch- } \\
\text { bishop of Salerno and later cardinal. } \\
\text { There is every reason to believe that the } \\
\text { Spanish poet was admitted to this aca- } \\
\text { demic circle, if not to its membership; at } \\
\text { least he was on terms of familiarity with } \\
\text { its leader Capece, for three years later he } \\
\text { dedicated to Garcilaso an edition of the } \\
\text { commentary of Aelius Claudius Donatus } \\
\text { on the Aenead, explaining that he had } \\
\text { been persuaded to publish this manu- } \\
\text { script, which had belonged to Pontanus, } \\
\text { by the opinion of his friend, whom he } \\
\text { names "a gentleman and a scholar (illus- } \\
\text { tris atque doctissime)." } 3 \text { Garcilaso men- }\end{array}$ \\
\hline & H I S A N I C NOTES \\
\hline
\end{tabular}




\section{LIFE A N D WORKS}

tions Minturno in one of his sonnets ${ }^{1}$ his friendship with Seripando is pictured in a letter which the Cardinal wrote years later to Placido di Sangro, a common friend of both, recalling how they had discussed together the meaning of a passage in Horace. ${ }^{2}$

Outside the academic circle, Garcilaso came into contact with several other men of letters to whom he was indebted. Among those who attached themselves to the Court of the new Viceroy was a young poet from Venosa, Luigi Tansillo, already known as the author of a pastorai poem, I due pellegrini. Although he was several years younger than Garcilaso, he seems to have been in close relations with him, if we may judge by a statement in one of his Capitoli,

Se io vo', per sodisfare al gusto vario, Parlando d'ogni cosa utile e spasso, Io parlerò con voi, general Mario; Così soleva far con Garzilasso Mentre con noi si stette e non si vide Fastidito del mondo, non già lasso. ${ }^{3}$

\section{A N D MONOGRAPHS}




\begin{tabular}{|l|l|}
\hline 120 & $\begin{array}{l}\text { GARCILASO DE LA VEGA } \\
\text { Two of his sonnets are addressed to Gar- } \\
\text { cilaso, and were early quoted by Herrera, } \\
\text { and Garcilaso refers to Tansillo in the } \\
\text { sonnet already mentioned. But the } \\
\text { clearest evidence of their mutual relations } \\
\text { is to be found in the study of their poems; } \\
\text { there we shall find clear proof of their } \\
\text { familiarity with each other's work, long } \\
\text { before these works were published. There } \\
\text { are at least two other Neapolitan poets } \\
\text { whom Garcilaso knew: Bernardo Tasso } \\
\text { and Giulio Cesare Caracciolo, to whom } \\
\text { he addressed one of his sonnets. His re- } \\
\text { lations with other members of the Court is } \\
\text { shown in his dedication of an occasional } \\
\text { sonnet, as those to Mario Galeota and to } \\
\text { Maria di Cardona, Marchesana della } \\
\text { Padula.2 } \\
\text { From these brief hints, culled for the } \\
\text { most from chance allusions, we may form } \\
\text { some conception of the society in which } \\
\text { Garcilaso mingled during these years at } \\
\text { Naples. The Court that gathered about } \\
\text { Pedro de Toledo was not merely brilliant; } \\
\text { like that of Francis I, it was thoroughly }\end{array}$ \\
\hline H I S P A N I C N O T E S \\
\hline
\end{tabular}




\section{I F E A N W ORKS}

imbued with the passion for art and we may think that under its influence the spirit of Garcilaso found an opportunity to expand in the direction dear to his heart. Luis Zapata has left an interesting anecdote of his stay in Naples which illustrates the atmosphere of his associations." "Many of the gentlemen of the Court of Spain," he says, "were at the house of a distinguished lady in Naples, where all the noble ladies of Italy were gathered; among the gentlemen was Garcilaso. And at sunset, which is the time of day when they prefer to feed the falcons and hawks, and also, between daylight and candlelight, the time when it is pleasant to visit the ladies, the servants officiously brought in the candles very early; whereat the whole company, both gentlemen and ladies, was greatly annoyed, and the lady herself. And she said, 'O sorda e cieca gente.' Garcilaso at once joined in with the end of the same line of Petrarch, 'a cui si fa notte innanzi sera.' " (Trionfo della morte, I, 38-39) Garcilaso however was not con-

\section{A N D MONOGRAP H S}




\begin{tabular}{|l|l|}
\hline 122 & $\begin{array}{l}\text { GARCILASO DE LA VEGA } \\
\text { tent merely to discuss and to quote the } \\
\text { Latin and Tuscan poets. Several of his } \\
\text { shorter poems must have been written } \\
\text { early in his stay at Naples, because they } \\
\text { breathe freshly his regret at his loss of } \\
\text { favor and his impatience at his sentence } \\
\text { of exile. }{ }^{1} \text { To the same period belongs also } \\
\text { his first Latin poem, the Ode ad Thylesium, } \\
\text { written to celebrate the tragedy Imber } \\
\text { aureus of Antonio Tilesio, which he had } \\
\text { read in the edition of I529. } \\
\text { It is possible that this first winter in } \\
\text { Naples brought to Garcilaso news of the } \\
\text { death of Isabel Freire. Even though we } \\
\text { cannot establish the exact date of her } \\
\text { death, we know that it must have occurred } \\
\text { in I533 or I534, for there is no reference } \\
\text { to it in the poems which Garcilaso wrote } \\
\text { during his confinement in Germany (March- } \\
\text { August, I532) and Sá de Miranda's ec- } \\
\text { logue Celia, which laments the event, was } \\
\text { certainly written in I } 535^{2} \text { and after the } \\
\text { composition of Garcilaso's own first ec- } \\
\text { logue, in which he speaks in such moving } \\
\text { terms of her departure. Isabel Freire had }\end{array}$ \\
\hline H I S P A N I C N O T E S \\
\hline and
\end{tabular}




\section{I F E A N D W O R S}

borne two children to her husband, a son, Antonio de Fonseca, and a daughter, Catalina de Fonseca. She died in giving birth to her third child. ${ }^{1}$ It is probable that Garcilaso's first eclogue was written immediately after he had received word of her death and the most exquisite of his sonnets, "O dulces prendas por mi mal halladas," plainly springs from the same inspiration.

Deep as was Garcilaso's regret, life at the Court of Don Pedro left little time for idle moping. His patron was eager to keep him before the eyes of the Emperor and on April I8, I533 he sent him with messages to His Caesarian Majesty. Charles V, having turned back the Turks before Vienna without a battle, had returned to Italy to conclude a defensive league with the Pope and the Italian states. As soon as this treaty had been settled he started for Spain by way of Genoa. But when Garcilaso reached the port, the Emperor had already sailed. $\mathrm{He}$ must have taken ship in his wake, for he

\section{A N D MONOGRAPHS}




\begin{tabular}{|l|l|}
\hline 124 & $\begin{array}{l}\text { GARCILASO DE LA VEGA } \\
\text { reached Barcelona on April 26th, three } \\
\text { days after the arrival of the Emperor who } \\
\text { had come overland from Rosas with the } \\
\text { Duke of Alba. In spite of the official } \\
\text { character of his visit, he found time for } \\
\text { some personal matters. It was probably } \\
\text { at this time that he reviewed with Boscán } \\
\text { the translation of Il cortegiano which the } \\
\text { latter had made. In the dedicatory letter } \\
\text { to the first edition of the Castilian trans- } \\
\text { lation, the privilege of which is dated } \\
\text { December 20, I533, Boscán begins, "Not } \\
\text { many days ago Garcilaso sent me, as Your } \\
\text { Ladyship knows, this book called The } \\
\text { Courtier, composed in the language of } \\
\text { Italy by Count Baltasar Castellón." In the } \\
\text { same edition there appeared a letter of } \\
\text { Garcilaso, also addressed to Doña Geró- } \\
\text { nima Palova de Almogavar, which gives } \\
\text { additional details as to Garciiaso's share } \\
\text { in the translation. }{ }^{3} \text { After explaining that } \\
\text { he had not ventured to suggest to Boscán } \\
\text { the desirability of translating Castiglione's } \\
\text { work, because he knew of the former's } \\
\text { scorn for those who turned books into }\end{array}$ \\
\hline H I S P A N I C N O T E S \\
\hline
\end{tabular}




\section{LIFE A N D W ORK S}

Spanish, he tells of the satisfaction which he has found in seeing so worthy a book so worthily translated. And then, for fear lest some one else might presume to print a version, with the perverse energy of those who write poor books, he urged his friend to publish it with all possible speed. He himself read its final proof, though he modestly disclaims any share in improving it. As this was the only time in I 533 that Garcilaso was in Spain, his consultation with Boscán must be placed here.

$\mathrm{He}$ also found time for a brief visit to Toledo, for on the $\mathrm{s} 2 \mathrm{th}$ of May he and his brother, Pedro Laso, informed the Alcalde of the death of their brother, Francisco de la Vega, at Bologna and requested permission to open his will. ${ }^{1}$ But Garcilaso was the bearer of messages from the Emperor to his Viceroy and he was forced to hurry on his way. He was in Naples again by the middle of June, ${ }^{2}$ in time to be a witness, if not a participator in the splendid bullfight which the Viceroy, himself a practiced toreador, gave in the Piazza Car-

\section{A N D M O O G R P H S}




\begin{tabular}{|l|l|}
\hline 126 & $\begin{array}{l}\text { GARCILASO DE LA VEGA } \\
\text { bonara at the end of the month. }{ }^{1} \text { In the } \\
\text { absence of any evidence, we must assume } \\
\text { that the next fourteen months were spent } \\
\text { in Naples. Early in this period must be } \\
\text { placed the composition of the second Ec- } \\
\text { logue, dedicated to the Duke of Alba. Gar- } \\
\text { cilaso ends the account of the Duke's ex- } \\
\text { ploits with his arrival in Spain and his } \\
\text { reunion with his wife. As we have seen, } \\
\text { Don Fernando reached Barcelona on Apri] } \\
\text { 23rd and the poet's failure to carry farther } \\
\text { the story of his friend and patron argues } \\
\text { that the poem must have been written not } \\
\text { long after that date. } \\
\text { At this period of his life there comes } \\
\text { into his sonnets a new note; a new passion } \\
\text { had supplanted his former love. At first } \\
\text { he struggled to resist, }\end{array}$ \\
\hline loco, impossible, vano, temeroso; \\
then follows a willingness to submit, - a \\
mood reflected in Canción IV; finally the \\
complete surrender which he confessed to \\
Boscán,
\end{tabular}




\section{I F E A N D W O K S}

Sabed que en mi perieta edad, y armado, con mis ojos abiertos, me he rendido al Niño que sabeys, ciego y desnudo.

If the phrase "en mi perfeta edad" is to be taken in its usual sense of "at the crown of life," in other words, "at the age of thirty-five," this stage of his love cannot have been reached before I536, unless he were born before I50I. ${ }^{1}$ It is idle to speculate who the object of this new desire may have been; his own answer remains final.

Si preguntado

soy lo que mas, en lo demas soy mudo.

At least this passion came to occupy a place of importance in his life; the lines with which he refers to it in his elegy to Boscán are marked by a real depth of feeling;

Alli mi coraçon turo su nido un tiempo ra; mas no se, triste, agora, o si estara ocupado o desparzido.

\section{A N D MONOGR A P H S}




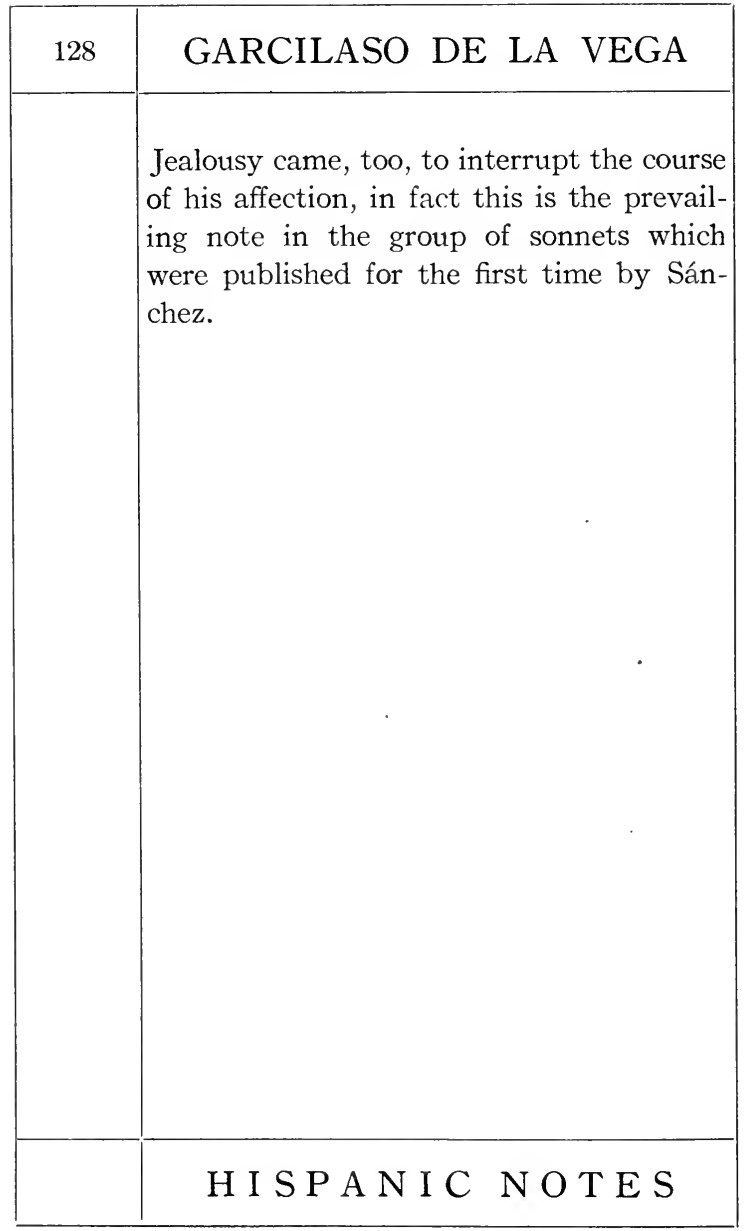




\section{IFE A N D W OR K}

\section{CHAPTER XII}

\section{THE EXPEDITION TO TUNIS}

The danger from the Turks on the East had hardly been repelled when another Moslem cloud appeared, this time in the South. Barbarossa, suddenly risen from piracy to authority, triumphant on land and sea, had received from the Sultan a commission as admiral of the fleet. Leaving Constantinople, he sailed into the western Mediterranean, ravaging the southern coast of Italy in August, I 534. On the $5^{\text {th }}$ of the month, Garcilaso was again dispatched to the Emperor with verbal instructions, to bear the tidings ${ }^{1}$. The Court was then at Palencia, so that it was well into September before he was able to deliver his urgent message. ${ }^{2}$ On the 29th he received the Emperor's reply and two days later he was on his way back to Naples, this time by land, fearing no doubt the possibility of capture at the

\section{A N D MONOGRAP H S}




\begin{tabular}{|c|c|}
\hline 130 & GARCILASO DE LA VEGA \\
\hline & $\begin{array}{l}\text { hands of Barbarossa's fleet. He slept at } \\
\text { Avignon on the night of October I } 2 \text { th, } \\
\text { one of the many pilgrims of the sixteenth } \\
\text { century to the grave of Laura. }{ }^{1} \text { We owe } \\
\text { the date to the closing lines of his Epistle } \\
\text { to Boscán, his only attempt at blank } \\
\text { verse; } \\
\text { Digo que vine, quanto a lo primero } \\
\text { tan sano como aquel que en doze dias } \\
\text { lo que solo vereys a caminado } \\
\text { quando el fin de la carta os lo mostrare... } \\
\text { doze del mes de Otubre, de la tierra } \\
\text { do nacio el claro fuego del Petrarca } \\
\text { y donde estan del fuego las cenizas. } \\
\text { Before Garcilaso had left Spain, the } \\
\text { Viceroy of Naples had written again to } \\
\text { Charles V (September I } \text { ), informing him } \\
\text { of the death of the chatelain of Reggio } \\
\text { (Rijoles) and requesting that Garcilaso } \\
\text { be appointed in his place. }{ }^{2} \text { Since he knew } \\
\text { that the Emperor never forgot an offense, } \\
\text { he admitted Garcilaso's past misdemeanors, } \\
\text { but at the same time called his attention } \\
\text { to the signal services which he had per- } \\
\text { formed and the desirability of his having }\end{array}$ \\
\hline & H I S A N I C NOTES \\
\hline
\end{tabular}




\section{IFE A N D WORKS}

his wife come to Italy and settle down with him. Despite the earnestness of his appeal, we must infer that the Emperor was not moved, for Garcilaso never received the appointment. Again in the following winter Charles $\mathrm{V}$ showed his obduracy. It seems that since Garcilaso's banishment, the Mesta, (a powerful organization of cattle-owners which controlled the industry in Spain) had refused to pay to him the income from the montazgo of Badajoz which his father had willed to him. Garcilaso had brought suit against the Mesta in the Chancery of Granada to recover this income, amounting to 85,000 maravedís a year. As he found it difficult to prosecute the case in his absence, he induced the Viceroy to write to the Emperor, begging him to grant a suspension, until such time as Garcilaso should return. The Emperor's reply was curt: "As for your request that we order a case which Garcilaso has in the court of Granada to be postponed, you are aware that we are not accustomed to postpone such matters,

\section{A N D MONOGRAPHS}




\begin{tabular}{|c|c|}
\hline 132 & GARCILASO DE LA VEGA \\
\hline & $\begin{array}{l}\text { nor is it consonant with the administra- } \\
\text { tion of justice."' He had neither forgot- } \\
\text { ten nor forgiven Garcilaso's share in the } \\
\text { affair at Ávila. } \\
\text { In the autumn of I } 534 \text { Charles V an- } \\
\text { nounced his determination to take the } \\
\text { field in force against Barbarossa and to } \\
\text { thwart his pretensions to Tunis, the occu- } \\
\text { pation of which by the Turks was a con- } \\
\text { stant menace to Christian trade in the } \\
\text { western Mediterranean. During the winter } \\
\text { the ship-yards and arsenals of Naples } \\
\text { were busy with the preparations for this } \\
\text { expedition. On May I }{ }^{2} \text { th of the following } \\
\text { year the fleet sailed for Cagliari in Sar- } \\
\text { dinia, the place appointed as the rendez- } \\
\text { vous for the Imperial forces, stopping at } \\
\text { Palermo to pick up the Sicilian contingent. }{ }^{3} \\
\text { Although the Viceroy did not take part } \\
\text { in this expedition, he sent his two sons, } \\
\text { Don Fadrique and Don García with them } \\
\text { went the leaders of the Spanish and Nea- } \\
\text { politan nobility of his Court, among the } \\
\text { number, Garcilaso. They reached Ca- } \\
\text { gliari early in June before the arrival of }\end{array}$ \\
\hline & H I PANIC NOTES \\
\hline
\end{tabular}




\section{IFE A N D WORK S}

the Emperor. A considerable armada had gathered, comprising detachments from all the Imperial possessions and a fleet under Andrea Doria. They reached Carthage on June r6th and the Emperor immediately proceeded to invest Goleta, a stronghold into which Barbarossa, realizing the weakness of the defenses of Tunis, had thrown some fifty thousand men. ${ }^{1}$ In spite of the Emperor's command, many of the gentlemen of his following recklessly entered into the skirmishes around the fort. In one of these encounters on June 22nd, a certain Pedro Suárez, stung by the taunts of Alonso de la Cueva', started forth alone to give battle to the enemy and although he was several times in dire peril and rescued by his friends, each time he returned to the strife. At last he was mortally wounded and even Alonso de la Cueva, who had gone out to aid him, was in danger, when the timely assistance of Garcilaso saved him. The poet was wounded in the face and arm, Sandoval tells us, but not seriously. ${ }^{2}$

\section{A N D MONOG R P H S}




\begin{tabular}{|c|c|}
\hline 134 & GARCILASO DE LA VEGA \\
\hline & $\begin{array}{l}\text { Paolo Giovio in his account of the cam- } \\
\text { paign tells a different story of the circum- } \\
\text { stances in which Garcilaso was wounded; } \\
\text { he was surrounded by a group of Arabs } \\
\text { and wounded but was rescued by a Nea- } \\
\text { politan gentleman, Federico Carrafa. }{ }^{1} \text { One } \\
\text { of the poet's own sonnets, addressed to } \\
\text { Mario Galeota, corroborates the truth of } \\
\text { their accounts, for he says, } \\
\text { Y ansi en la parte que la diestra mano } \\
\text { govierna y en aquella. que declara } \\
\text { los concetos del alma fuy herido. } \\
\text { We should be inclined to suspect that the } \\
\text { versions of the historians were written } \\
\text { après coup to explain the reference of the } \\
\text { poem, were it not for the fact that in a } \\
\text { letter of Enrique Enríquez de Guzmán } \\
\text { written to his father the Count of Alba on } \\
\text { June } 22 \text { nd, }{ }^{2} \text { he states explicitly, "The Em- } \\
\text { peror is insistent that none of the gentle- } \\
\text { men shall engage in skirmishing. Garci- } \\
\text { laso received. two lance wounds; the one } \\
\text { in the mouth was trifling and the other } \\
\text { in the arm was fairly serious, but they are }\end{array}$ \\
\hline & H I S A N I C NOTES \\
\hline
\end{tabular}




\section{IFE A N D WORKS}

not dangerous." Even so it is possible that the exact details of the engagement were doubtful and thus it happened that different versions of the same event found there way to those who chronicled the campaign. Fernández de Navarrete, without citing any authority either oral or written, adds the amusing comment that this wound in the mouth somewhat disfigured his beauty and also impeded his speech, but that the latter added to his popularity by virtue of a sort of childish accent which it gave to his delivery. ${ }^{1}$

Garcilaso's wounds were no doubt quickly healed; at least they did not prevent his taking part in the remainder of the campaign. Goleta was taken on July I 4 th and on the 2and the Emperor entered Tunis. $^{2}$ As soon as he had firmly propped Muley-Hascen on his unstable throne, he disbanded his forces and embarked on August I 7 th for Sicily. His fleet reached Trapani on the western coast of the island on the 22nd. Here Garcilaso wrote to Boscán the Elegy beginning,

\section{A N D MONOGRAPHS}




\begin{tabular}{|c|c|}
\hline 136 & GARCILASO DE LA VEGA \\
\hline & $\begin{array}{l}\text { Aqui, Boscan, donde del buen Troyano } \\
\text { Anchises con eterno nombre y vida } \\
\text { conserva la ceniza el Mantuano, } \\
\text { debaxo de la seña esclarecida } \\
\text { de Caesar Affricano nos hallamos } \\
\text { la vencedora gente recogida. } \\
\text { This was the first visit of Charles V to } \\
\text { his Sicilian possessions and he made his } \\
\text { way overland to Palermo, while his fleet } \\
\text { proceeded directly to that harbor. On } \\
\text { this voyage there died Bernardino de } \\
\text { Toledo, brother of the Duke of Alba, who } \\
\text { had been ill during most of the campaign } \\
\text { with a disease which was prevalent during } \\
\text { the early sixteenth century. A letter of } \\
\text { the Count of Nieva, written at Palermo } \\
\text { on the 6th of September records the sor- } \\
\text { row of the whole company, for he was } \\
\text { looked upon as a "royal good fellow (muy } \\
\text { mozo y hombre de bien)."1 It was to com- } \\
\text { memorate his death that Garcilaso adapted } \\
\text { the Latin elegy of Fracastoro on the death } \\
\text { of Marcantonio de la Torre in the Castil- } \\
\text { ian version which he dedicated to his } \\
\text { friend the Duke of Alba. }\end{array}$ \\
\hline & H I P A N I C NOTES \\
\hline
\end{tabular}




\section{IFE A N D WORK S}

In the light of subsequent events we may judge that Garcilaso's bravery at La Goleta had restored him to the favor of the Emperor and that he accompanied him during this visit in Sicily. By the end of October His Majesty had finished his official business at Palermo and Messina, and crossed over into Calabria. ${ }^{1}$ When they reached the outskirts of Naples on November 22nd, it was learned that the triumphal arches and other decorations which were being prepared in the city in honor of his first entrance were not yet ready; he therefore spent three days at Leucopetra, the villa of the secretary, Martirano. With great pomp and rejcicing Charles $\mathrm{V}$ and his company entered Naples on the $25^{\text {th }}$, escorted by the Prince of Salerno. ${ }^{2}$ The winter which followed was one of unusual delight. For two months and a half a cloudless sky and a springtide warmth offered occasion for the ceaseless rounds of jousts, masques and fêtes, in which the most distinguished nobles and ladies of Italy and of Spain

\section{A N D MONOGRAPH S}




\begin{tabular}{|c|c|}
\hline 138 & GARCILASO DE LA VEGA \\
\hline & $\begin{array}{l}\text { took part. }{ }^{1} \text { Garcilaso, freed from the } \\
\text { cloud which had hung over him, must } \\
\text { have found these months the most event- } \\
\text { ful in his life. Before his departure for } \\
\text { Africa, he had sent to Pietro Bembo, } \\
\text { through Girolamo Seripando, several Latin } \\
\text { odes, one of them addressed to the dis- } \\
\text { tinguished Venetian. Late in August, } \\
\text { Bembo wrote to him a letter in Latin to } \\
\text { express his thanks and appreciation. }{ }^{2} \text { His } \\
\text { praise was not equivocal when he used } \\
\text { such terms as these: "I have read almost } \\
\text { nothing written in these times with greater } \\
\text { elegance, judgment, purity or dignity." } \\
\text { Aside from the consideration that Gar- } \\
\text { cilaso's cult of the Classics made his work } \\
\text { dear to Bembo, it were well to observe } \\
\text { that in this same letter he has a particular } \\
\text { favor to ask of the Spanish poet, his inter- } \\
\text { cession with the Emperor in behalf of the } \\
\text { brother of his friend, the friar Onorato Fa- } \\
\text { scitelli, who was the bearer of the letter to } \\
\text { Garcilaso. In a letter to Fascitelli, written } \\
\text { at the same time, }{ }^{3} \text { he speaks with enthusi- } \\
\text { asm of Garcilaso's verse and of the prom- }\end{array}$ \\
\hline & H I P A N I C N T E S \\
\hline
\end{tabular}




\section{LIFE A N D W O R K}

ise which he gives of surpassing even his Italian contemporaries, and adds that he is not surprised that the Marquis of Vasto holds him in esteem and is eager to have him in his company, as Seripando has told him. ${ }^{1}$ We may be sure that Garcilaso's gratitude toward his protector the Viceroy was sufficient to keep him from deserting to the service of his principal rival.

Another interesting glimpse of Garcilaso's acquaintanceship is offered by a letter of Juan Ginés Sepúlveda to Luis de Ávila y Zúniga, written at Rome on January 12,1536 , in which he thanks the historian for a copy of his history of the campaign of Tunis, which the latter had intrusted to Garcilaso for delivery. ${ }^{2}$ The letter closes with a brief, but delicate tribute to his two friends: "And yet you expect no thanks for such good offices, for I perceive that you are intent upon adding to your glory by the honors that come from letters, and upon encouraging studies of this sort in every possible way, so that men ought rather to praise your purpose

\section{A N D MONOGRAPH S}




\begin{tabular}{|l|l|}
\hline 140 & $\begin{array}{l}\text { GARCILASO DE LA VEGA } \\
\text { than thank you for it." It is not unlikely } \\
\text { that Garcilaso delivered this manuscript } \\
\text { to Sepúlveda in person, whom he may } \\
\text { have met already during the period when } \\
\text { Charles V was in Italy for his coronation, } \\
\text { for Sepúlveda was then in the suite of the } \\
\text { Cardinal Quinón. }{ }^{1} \text { Under any circum- } \\
\text { stances his interest in letters must have } \\
\text { been a source of great satisfaction to } \\
\text { Sepúlveda. The latter had just published } \\
\text { at Rome his dialogue Democrates, dedi- } \\
\text { cated to the Duke of Alba, an attempt to } \\
\text { reconcile the practice of warfare with the } \\
\text { precepts of Christianity. In the opening } \\
\text { paragraph he had expressed the delight } \\
\text { which he had felt at Bologna in I 53o upon } \\
\text { inding that the young Spanish noblemen } \\
\text { whom he met at that time at the Court of } \\
\text { Charles V had ceased to believe, as had } \\
\text { their fathers, that the profession of arms } \\
\text { was the only one becoming a gentleman } \\
\text { and had begun to show a certain inclina- } \\
\text { tion to literature and learning. In a meas- } \\
\text { ure. Garcilaso exemplified the type which } \\
\text { he was eager to encourage, and his admir- }\end{array}$ \\
\hline H I S P A N I C N O T E S \\
\hline
\end{tabular}




\section{LIFE A N D W ORK S}

ation for the soldier-poet of Toledo was now increased by a Latin ode which Garcilaso dedicated to him. In this poem, the author refers specifically to the Democrates,

Arcum quando adeo relligionis saevae militiae ducere longius ut curvata coire inter se capita haud negent, una musa tibi, docte Sepulveda, concessit.

And he also mentions the history of the campaign in Tunis which he was writing, assisted, as Sepúlveda himself admits, ${ }^{1}$ by the account which he received from Ávila y Zúñiga,

...pariter dicere et Africam incumbit pavitantem

sub rege intrepido et pio.

Both as a courtier and as a man of letters, Garcilaso was beginning to win favor.

\section{A N D M O N O R A P H S}




\begin{tabular}{|c|c|}
\hline 142 & GARCILASO DE LA VEGA \\
\hline & $\begin{array}{l}\text { CHAPTER XIII } \\
\text { THE LAST CAMPAIGN } \\
\text { The rivalry between Francis I and } \\
\text { Charles V had begun in their youth when } \\
\text { they were candidates for the Imperial } \\
\text { crown. This rivalry had developed into } \\
\text { a veritable hatred after the part which } \\
\text { the French king had played in breaking } \\
\text { the terms of the Peace of Madrid, nor } \\
\text { had the Peace of Cambray, three years } \\
\text { later, been more than the expression of } \\
\text { their need for a brief breathing space. } \\
\text { Since I } 529 \text { Francis I had been pursuing } \\
\text { a curious course. Engaged in overt or } \\
\text { covert negotiations with the German } \\
\text { Protestants and even with Solyman the } \\
\text { Magnificent, he had lost no opportunity } \\
\text { of acting to the detriment of Charles V, } \\
\text { seeking always a pretext to incite the } \\
\text { other princes of Europe to open revolt } \\
\text { against him. Having failed to come to } \\
\text { an agreement with the Emperor concern- } \\
\text { ing the disposition of the duchy of Milan, }\end{array}$ \\
\hline & H I S A N I C NOTES \\
\hline
\end{tabular}




\section{I F E A D W O R K S}

he invaded Savoy in the spring of ${ }_{153} 6$ and seized Turin. The Emperor left Naples on March 22nd, entering Rome on April 5th. There, on the Monday after Easter (April $\mathrm{I} \mathrm{t}_{\text {th) }}$ in the presence of the Pope, the College of Cardinals and the ambassadors, he delivered his famous invective against his rival, announcing his determination to take up the gage of war which Francis I had thrown down. ${ }^{1}$

We should suppose that Garcilaso accompanied the Emperor on this trip, were it not for a curious tale in the Carlo famoso of Zapata, which if it savors rather of romance than of documentary evidence, has nothing in it to render unlikely the background of fact from which such a fanciful tradition may have arisen. ${ }^{2}$ Briefly, the story which the garrulous author has spread over twenty-two octaves,

$$
\text { ... por alegrar al que desvela }
$$

su espiritu, escuchando este gran cuento,

is as follows. Garcilaso, commissioned by the Emperor to accompany a Neapolitan

\section{A N D MONOGRAPH S}




\begin{tabular}{|c|c|}
\hline 144 & GARCILASO DE LA VEGA \\
\hline & $\begin{array}{l}\text { lady to her estate and administer punish- } \\
\text { ment to one of her relatives who had } \\
\text { attempted to seize her property, was } \\
\text { wounded in the encounter which the execu- } \\
\text { tion of his task involved and forced to } \\
\text { remain in the house of the lady. Mean- } \\
\text { while Charles V had left the city. Gar- } \\
\text { cilaso, before his wounds were wholly } \\
\text { healed, accepting as a reward only a horse } \\
\text { and a lance to replace those which he had } \\
\text { lost in the combat, started for Rome at- } \\
\text { tended only by his squire. One day as he } \\
\text { fared upon his solitary way he met a } \\
\text { maiden who expressed her surprise that } \\
\text { he should venture to travel thus alone, } \\
\text { inasmuch as the roads were infested by } \\
\text { highwaymen, - a report which was cor- } \\
\text { roborated by the keeper of the inn where } \\
\text { he had lodged that night. Garcilaso was } \\
\text { nothing daunted and continued on his way. } \\
\text { Now it chanced that in a wooded place } \\
\text { near Velletri he was suddenly set upon by } \\
\text { a band of more than three hundred (!) } \\
\text { ruthless brigands. Placing his lance in the } \\
\text { rest, he charged upon them. One he slew; }\end{array}$ \\
\hline & H I P A I C NOTES \\
\hline
\end{tabular}




\section{LIFE AND WORKS}

two more he stretched upon the sod; a score he wounded. The wicked band, dismayed at the fierceness of his onslaught, turned in flight and only then did he discover that they had stripped his squire and bound him naked to a tree. Loosing his bonds, he presented him with the suit of one of his victims and once more, unperturbed, proceeded on his way. The episode has all the earmarks of the chivalrous romance; such incidents are the everyday affair of the knights of Boiardo and of Ariosto. But whether or not we care to admit the possibility even of an historical basis of fact, it has its interest and its value as pointing to that cult of Garcilaso's prowess which has persisted down to his modern biographers. Zapata was a contemporary and hence may be looked upon as in some degree representing the sentiment of his own generation.

It is to Zapata again that we are indebted for an anecdote concerning the poet, included in his Miscelanea, which may refer to his departure from Naples at this

\section{A N D MONOGRAPH S}




\begin{tabular}{|c|c|}
\hline 146 & GARCILASO DE LA VEGA \\
\hline & $\begin{array}{l}\text { time. "Garcilaso," he says, "was on very } \\
\text { intimate terms with the Viceroy, the Mar- } \\
\text { quis of Villafranca and he remained as one } \\
\text { of his court. But his intimacy disappeared } \\
\text { like false alchemy in smoke. And Don } \\
\text { Pedro de Toledo, whom they called 'the } \\
\text { German,' because he spoke it, discussing } \\
\text { with Garcilaso the possibility of his re- } \\
\text { maining with him, when he was going away } \\
\text { without a very plentiful provision, said } \\
\text { to him, } \\
\text { Heu fuge crudelis terras, fuge litus avarum. } \\
\text { Nam Polydorus ego." (Aenead, III, 44-45) } \\
\text { If the story is authentic, it may well reflect } \\
\text { the pique of the Viceroy on learning that } \\
\text { Garcilaso was to leave his service for that } \\
\text { of the Emperor; at least it presents him } \\
\text { as a student of the Classics. } \\
\text { The Emperor and his company left Rome } \\
\text { on April r8th. }{ }^{2} \text { In ten days they were in } \\
\text { Florence. From there on the } 4 \text { th of May } \\
\text { the Emperor, about to start for Pistoia, } \\
\text { dispatched Garcilaso, whom he had ap- } \\
\text { pointed maestre de campo of the three }\end{array}$ \\
\hline & H I S P N I C NOTES \\
\hline
\end{tabular}




\section{IFE A N D ORK .}

thousand Spanish troops that were coming to join the expedition into France, with instructions for Andrea Doria and Antonio de Leiva, his commanders-in-chief. Two hours before day-break on the 6th Garcilaso delivered his messages to Andrea Doria, who was then in Genoa, and to the Imperial ambassador, Gómez Suárez de Figueroa, and immediately continued on his way to Rivarrota near Milan, where the Captain-General was encamped. The journey took two days and he again started at once for Sarzano, which the Emperor had planned to reach on the roth. Charles $\mathrm{V}$ was evidently delayed, for not until Friday the $\mathrm{r} 2$ th did he arrive at Sarzano. There he received from Garcilaso the answer of Antonio de Leiva.

For the next four days Garcilaso traveled in the company of the Imperial forces, in which time they came to Fornovo. On the $I 7$ th he was once more sent to Genoa with orders to hold the Spanish troops, which were hourly expected, between that city and Alessandria, until the Emperor

\section{A N D M O N G R A P H S}




\begin{tabular}{|l|l|}
\hline 148 & $\begin{array}{l}\text { GARCILASO DE LA VEGA } \\
\text { should reach the latter town. At the same } \\
\text { time he was given a commission as captain } \\
\text { of one of the eleven companies into which } \\
\text { the Spanish troops were divided. On the } \\
\text { 2oth he wrote to the Emperor from Genoa } \\
\text { the autograph letter is preserved) that the } \\
\text { forces had arrived and that it was their } \\
\text { intention, in accordance with the instruc- } \\
\text { tions of Andrea Doria, to disembark them } \\
\text { at Savona and move toward Alessandria. } \\
\text { Charles V reached Alessandria on the 24th } \\
\text { and having advanced as far as Asti on the } \\
\text { 26th, decided to await developments there. } \\
\text { Garcilaso's troops were therefore called up } \\
\text { and lodged in the suburbs of the town. } \\
\text { Antonio de Leiva had laid siege to the } \\
\text { fortress of Fossano near Savigliano. The } \\
\text { operation dragged along for nearly a month } \\
\text { more before the place capitulated on June } \\
\text { 24th. Two days prior to the surrender, } \\
\text { the Emperor moved on to Savigliano by } \\
\text { way of Alba. The garrison of Fossano had } \\
\text { given up the fortress on condition that } \\
\text { they be allowed twelve days in which to } \\
\text { remove their munitions. Not until the }\end{array}$ \\
\hline $\begin{array}{l}\text { H I S P A N I C N O T E S } \\
\text { theng }\end{array}$ \\
\hline
\end{tabular}




\section{I F A N D W ORK}

6th of July, then, did they evacuate the town, so that the Emperor was forced to wait in Savigliano. The occupation of the town by the Imperial troops and the preparations for the advance into France required another ten days. It was July i 7 th before the expedition started across the mountains.

Just before their departure (July $\mathrm{I}_{5}$ th) Garcilaso wrote to his friend Seripando that it was generally believed that before another week they would be on their way to France. There is a reference in this letter to certain enmities of which we know nothing further, but which may explain the recklessness which he showed in his eagerness to please the Emperor. "I am in good health," he writes, "and I should be comfortable in every other respect, if I had enemies who were more influential or less influential. The fact that they are not really influential makes them injure me in a way unbecoming gentlemen, and the fact that they are not wholly without influence gives them suc-

\section{A N D MONOGRAPH S}




\begin{tabular}{|c|c|}
\hline 150 & GARCILASO DE LA VEGA \\
\hline & $\begin{array}{l}\text { cess in some of their efforts. But in spite of } \\
\text { this, they weep more times a day than } \\
\text { they laugh." } 1 \\
\text { It seems probable that at some time dur- } \\
\text { ing this campaign was written the last of } \\
\text { Garcilaso's longer poems, the third Ec- } \\
\text { logue. A passage in this poem, one of the } \\
\text { most widely quoted of his works, definitely } \\
\text { places its composition in the midst of war- } \\
\text { fare; } \\
\text { Entre las armas del sangriento Marte, } \\
\text { do apenas ay quien su furor contrasta, } \\
\text { hurte del tiempo aquesta breve suma, } \\
\text { tomando ora la espada, ora la pluma. } \\
\text { It is true that these words might be ap- } \\
\text { plied as well to the campaign in Africa, } \\
\text { but there is a phrase in the first stanza of } \\
\text { the poem, } \\
\text { a despecho y pesar de la ventura } \\
\text { que por otro camino me desvia, } \\
\text { which renders it probable that it was writ- } \\
\text { ten after his return to the service of the } \\
\text { Emperor. }{ }^{3} \text { At least we may be sure that } \\
\text { it was written some time after the compo- }\end{array}$ \\
\hline & H I P A N I N OTES \\
\hline
\end{tabular}




\section{LIFE A N D WORKS}

sition of the first Eclogue, for he refers to the death of Elisa (Isabel Freire),

que en aquella ribera deleytosa de Nemoroso fue tan celebrada.

From the lines,

Responde el Tajo y lleva pressuroso al mar de Lusitania el nombre mio, donde sera escuchado, yo lo fio,

one is tempted to think that he had already heard of Sá de Miranda's Celia, (1535), with its answer,

Corren lagrimas justas sin parar, ${ }^{1}$ to his own refrain of the first Eclogue,

Salid sin duelo, lagrimas, corriendo.

It was the $\mathrm{I} 7$ th of July when Charles V with his infantry left Savigliano for France. To detail the events of this brief but disastrous campaign would add little to our knowledge of Garcilaso. Although the losses from wounds were small, the difficulty of procuring provisions in a country devastated by its own inhabitants made

\section{A N D MONOGRAPH S}




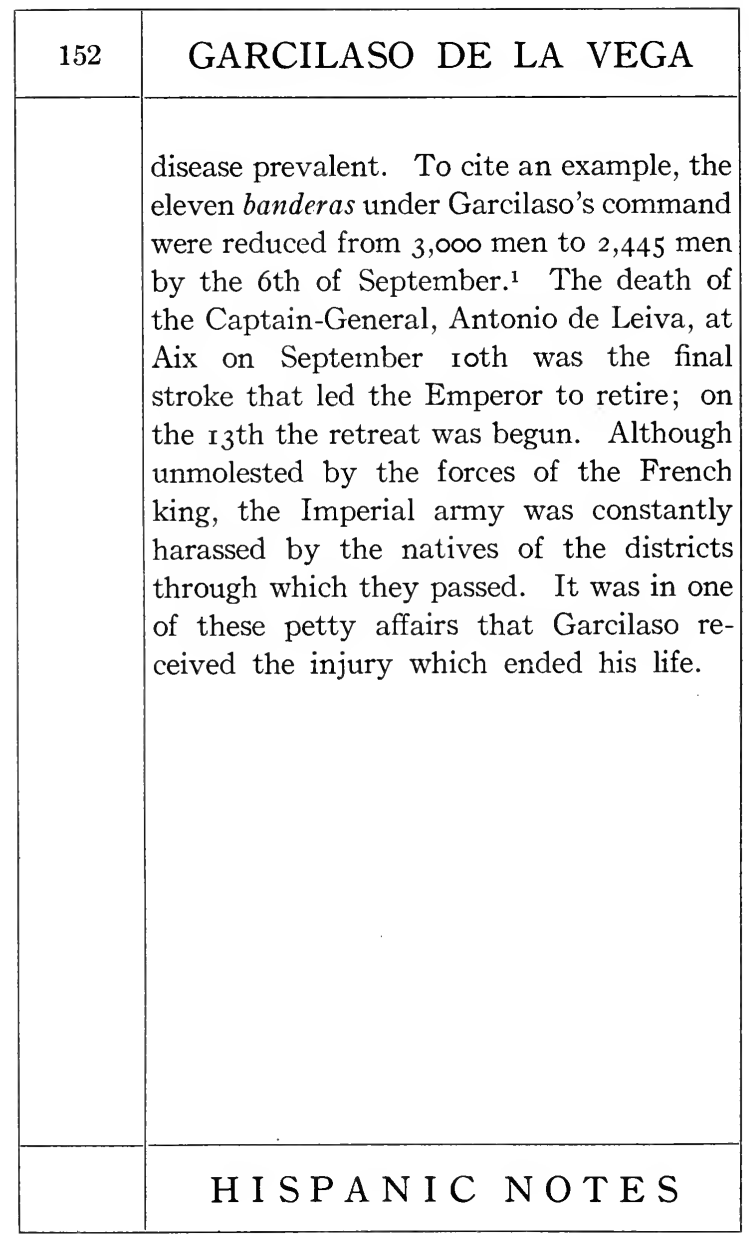





\begin{tabular}{|c|c|}
\hline 154 & GARCILASO DE LA VEGA \\
\hline & $\begin{array}{l}\text { concealed in the tower so that they had } \\
\text { not been seen until one of the members } \\
\text { of the Emperor's suite, desiring to climb } \\
\text { up into the tower by a ladder that he set } \\
\text { up, the men in the tower let him come up } \\
\text { to the second story, or arch, but when } \\
\text { he started to climb to the top, where they } \\
\text { were, one of them came to the opening of } \\
\text { the arch and told him not to come up. At } \\
\text { this the man who was climbing up asked } \\
\text { him who the people in the tower were and } \\
\text { he told him that they were Frenchmen and } \\
\text { that he mustn't go up there. At this the } \\
\text { member of the Emperor's suite went down } \\
\text { and told the Emperor. When the Emperor } \\
\text { heard it, he ordered them to go and find } \\
\text { out who they were, and so some gentlemen } \\
\text { went, asking them what they were doing } \\
\text { there. They said it was their land and } \\
\text { they were going to stay there; the gentle- } \\
\text { men told them to come down out of the } \\
\text { tower and go where they liked, and they } \\
\text { answered that they didn't want to leave } \\
\text { the tower. At this the Emperor wanted } \\
\text { to see who they were and what they were }\end{array}$ \\
\hline & H I S A N I C NOTES \\
\hline
\end{tabular}




\section{I F E A D W ORK S}

there for and so he ordered that fire should be opened on the tower with a battery which had arrived with the vanguard and so this was done and a little breach was opened in the tower. When this breach was made, Don Jerónimo de Urrea, a Spanish gentleman, with a sorry ladder rushed to the tower and entered through the breach. After Don Jerónimo de Urrea, Captain Maldonado and the maese de campo, Garcilaso de la Vega, wanted to go up, and there was some discussion as to which should go first. Just at this minute up comes Don Guillén de Moncada, son of Don Hugo de Moncada, saying, 'Gentlemen, I beg you, since you have so much honor, let me win a little honor.' Immediately Captain Maldonado answered him, saying, 'For so valiant a gentleman this is but little honor. Go up.' And so the second person was Don Guillén de Moncada. While Garcilaso de la Vega and Captain Maldonado were going up, the men in the tower dropped a big, heavy stone, and it strikes the ladder and breaks

\section{A N D MONOGRAPHS}




\begin{tabular}{|c|c|}
\hline 156 & GARCILASO DE LA VEGA \\
\hline & $\begin{array}{l}\text { it, and so the maese de campo and the } \\
\text { Captain fell, and the maese de campo was } \\
\text { badly wounded in the head, from which } \\
\text { he died a few days later." } \\
\text { In the Carlo famoso, Zapata gives an } \\
\text { almost identical account of the affair; the } \\
\text { number of farmers is thirteen and Jerónimo } \\
\text { de Urrea and Guillén de Moncada are the } \\
\text { gentlemen who finally receive their sur- } \\
\text { render. He attributes to Garcilaso and } \\
\text { not to Maldonado the statement, } \\
\text { sera el qu' en una impresa tan vil muera, } \\
\text { and makes him the first to climb the lad- } \\
\text { der, wearing an ordinary cap, which he } \\
\text { has snatched from a passing soldier, in- } \\
\text { stead of a helmet, and without a cuirass. } \\
\text { But these are details which concern rather } \\
\text { the picturesqueness of the account. From } \\
\text { the French side, also, we have a version of } \\
\text { this episode of the retreat in a fragment } \\
\text { of the Ogdoades of Guillaume du Bellay. } \\
\text { Messire Guillaume does not mention the } \\
\text { name of the Spanish gentleman who was }\end{array}$ \\
\hline & H I P A N I C NOTES \\
\hline
\end{tabular}




\section{LIFE A N D WORKS}

wounded, but he gives several interesting facts of the story. Most important is his assertion that it was the intention of the farmers to kill Charles $\mathrm{V}$, and that taking another gentleman for him, on account of the richness of his dress, they rolled down onto him the stone which fatally wounded him. Du Bellay is the first to place the number of the men in the tower at fifty, a figure which was accepted by Herrera ${ }^{1}$ and by most of his later biographers. ${ }^{2}$

Cerezeda goes on to tell how the men in the tower finally surrendered on condition that they should not be sent to the galleys; and how the Emperor, finding that they "had not behaved as good soldiers," kept his word by cutting off the ears of the boys and hanging the men at the window of a near-by building. Zapata gives his actual words, versified, saying that when Luis de la Cueva, who had been ordered to execute the Provençaux, asked if all should be hung, the Emperor replied,

A todos les estiren de los cuellos.

\section{A N D MONOGRAPHS}




\begin{tabular}{|l|l|}
\hline 158 & $\begin{array}{l}\text { GARCILASO DE LA VEGA } \\
\text { It was the cruel vengeance of Charles V } \\
\text { and not the loss of one of his courtiers } \\
\text { which has lingered in the minds of the } \\
\text { natives. Today the tower, "tall and } \\
\text { round," which still stands just outside of } \\
\text { the village of Le Muy, stirred only by the } \\
\text { crooning of the pigeons that build their } \\
\text { nests in the dusty rafters of its roof, is } \\
\text { called "La tour Charles-Quint," though } \\
\text { the miller, whose plant occupies the "little } \\
\text { house" adjoining, never dreams that his } \\
\text { hardy ancestors once paid there so bitter } \\
\text { a penalty for their daring. } \\
\text { After his injury Garcilaso was carried } \\
\text { to Nice. There he died at the residence of } \\
\text { the Duke of Savoy on October I3, I 536.1 } \\
\text { We will not linger over the edifying details } \\
\text { of his pious repentance and regrets for his } \\
\text { past folly in devoting himself to art, as } \\
\text { they are recorded by Cienfuegos; the } \\
\text { biographer was penning the life of a } \\
\text { saint." But we may believe that he died } \\
\text { bravely, as he had lived, } \\
\text { Sepan que ya no puedo }\end{array}$ \\
\hline H I S P A N I C N O T E S
\end{tabular}




\section{I F E A N D W O R K S}

There is a strange irony in the manner of his death, which almost literally fulfills the words which he had written in the preceding year,

$Y$ esta no permitio mi dura suerte que me sobreviniesse peleando, de hierro traspassado agudo y fuerte,

not killed in open combat with his peers, but struck down in a miserable squabble with a group of peasants. And yet the manner of his death is of little moment. He had spent his whole life in the service of his king. To that service he gave the last gift he had to give, his life.

\section{A N D MONOGRAPH S}




\begin{tabular}{|c|c|}
\hline 160 & GARCILASO DE LA VEGA \\
\hline & $\begin{array}{l}\text { XV } \\
\text { THE CHAPEL OF THE ROSARY } \\
\text { There is an account in the Carlo famoso } \\
\text { of how Lope de Guzmán and Rodrigo Niño } \\
\text { brought the sad news of Garcilaso's death } \\
\text { to his wife and of her grief and lament. } \\
\text { The Emperor however provided liberally } \\
\text { for her and for her children, }{ }^{2} \text { and the Duke } \\
\text { of Alba, Zapata tells us in his Miscelanea, } \\
\text { continued to show his affection for the } \\
\text { poet, who had paid such constant tribute } \\
\text { to him, by the concern that he showed for } \\
\text { his family. Doña Elena de Zúñiga opened } \\
\text { the will, which her husband had drawn up } \\
\text { eight years before, in the presence of the } \\
\text { alcalde of Toledo on January } 3 \text {, I537. } \\
\text { Three days later his mother, Doña Sancha } \\
\text { de Guzmán, died, }{ }^{5} \text { leaving her estate to } \\
\text { her son, Pedro Laso, her daughter, the } \\
\text { Countess of Palma, and Doña Elena de } \\
\text { Guzmán, as mother of Garcilaso's children. } \\
\text { On May and Doña Elena presented witnes- } \\
\text { ses to prove her husband's death }{ }^{6} \text { and at }\end{array}$ \\
\hline & H I S A N I C NOTES \\
\hline
\end{tabular}




\section{LIFE A N D W O R S}

161

the end of the year applied for confirmation of her legal guardianship over her children. ${ }^{1}$ Of the three sons which Garcilaso had named in his will in 1529 , the eldest, Garcilaso was already dead, for she mentions only Ínigo and Pedro. In addition she speaks of two other children, a daughter Sancha, then five years, and a son Francisco, a little over two years of age. It is probable that the oldest surviving son, Iñigo, assumed his deceased brother's name during the following year, for on June 2I, 1539 the Emperor granted to Garcilaso de la Vega, son of the poet, a stipend of 80,000 maravedís a year until such time as he should receive him into his household or make other provision for him. ${ }^{2}$

The career of the heir to the poet's name and estate was as brief as was his father's. While he was still a youth he was admitted to the Order of Santiago in I $543 .^{3}$ One of the witnesses to his nobility was his father's friend, the Duke of Alba, who admitted that he was a kinsman of

\section{A N D M O N O R A P H S}




\begin{tabular}{|c|c|}
\hline 162 & GARCILASO DE LA VEGA \\
\hline & $\begin{array}{l}\text { the applicant within the fourth degree. } \\
\text { Another of the witnesses, Francisco Ruiz } \\
\text { de Herrera, an old friend of the family who } \\
\text { had carried him in his arms to be baptized, } \\
\text { declared that he was "studying Latin and } \\
\text { Greek and other accomplishments such as } \\
\text { become a virtuous lad." It is probable } \\
\text { that he studied later at the University of } \\
\text { Salamanca. He is the author of a Latin } \\
\text { epigram to Hernando de Acuña and it is } \\
\text { probable that the poems by Garcilaso which } \\
\text { are found in the collection of cartapacios } \\
\text { from Salamanca now in the Royal Library } \\
\text { in Madrid, are from his pen. He later } \\
\text { entered the service of the Emperor. In } \\
\text { February I } 55 \text { I he was with the Court at } \\
\text { Augsburg. Four years later, on October } \\
4 \text { I } 555 \text {, he was killed in the defense of } \\
\text { Volpiano, near Turin. It is interesting } \\
\text { to know that in the councils of the cap- } \\
\text { tains during his last days, his advice was } \\
\text { listened to with respect because they knew } \\
\text { "that he was intimate with the Duke of } \\
\text { Alba." He had inherited his father's } \\
\text { friendships as well as his name. }\end{array}$ \\
\hline & H I SPA I C NOTES \\
\hline
\end{tabular}




\section{I F E A N D W O R K S}

The third son of Garcilaso, Pedro de Guzmán, early showed an inclination for religion; on August 29, I 543 he ceded his share in his father's estate to his mother and assuming the name of one of his early kinsmen, Domingo de Guzmán, entered the Dominican order. ${ }^{1}$ A Master of the University of Salamanca, he became famous as a preacher and as a teacher. When Luis de León wrote the verses, "Aquí la envidia y mentira" upon his release from prison in 1576 , Fray Domingo answered them with a gloss, beginning "Porque las dañadas leyes," 2 which must have gained a certain celebrity, for Cervantes borrowed four lines,

$$
\begin{aligned}
& \text { ¿Que don Alvaro de Luna, } \\
& \text { que Annibal cartagines } \\
& \text { que Francisco, rey frances } \\
& \text { se quexa de la fortuna? }
\end{aligned}
$$

in the verses of "Urganda la Desconocida," which introduce the first part of the Quixote. In 1579 he was a candidate for the Chair of Sacred Scripture at Salamanca but was defeated by Luis de León.

\section{A N D MONOGRAPHS}




\begin{tabular}{|c|c|}
\hline 164 & GARCILASO DE LA VEGA \\
\hline & $\begin{array}{l}\text { The vote was very close and the litigation } \\
\text { over the decision lasted until October, I } 5^{81} \text {, } \\
\text { when Luis de León was declared elected. } \\
\text { Years later, however, when both the can- } \\
\text { didates were dead, some one, troubled by } \\
\text { a guilty conscience, appeared at the mon- } \\
\text { astery of San Esteban in Salamanca, of } \\
\text { which Fray Domingo was a member, and } \\
\text { offered the Order eight thousand reales, } \\
\text { declaring that he had voted against Fray } \\
\text { Domingo in that election, although he was } \\
\text { not qualified to vote, and wished now to } \\
\text { make some amends for the injustice which } \\
\text { his illegal act had done. Before his death } \\
\text { Domingo de Guzmán was elected to the } \\
\text { chair which was called "de Durando." He } \\
\text { was still lecturing when he died in July, } \\
\text { I582. } \\
\text { Francisco de la Vega, Garcilaso's young- } \\
\text { est son, died when he was a boy. }{ }^{2} \text { His only } \\
\text { daughter, Sancha de Guzmán, was mar- } \\
\text { ried to her cousin, Antonio Puertocarrero, } \\
\text { younger son of the Count of Palma, in } \\
\text { May, I } 55^{1}{ }^{3} \text { Her mother provided. her } \\
\text { with an unusually large dowry, five mil- }\end{array}$ \\
\hline & H I PA N I C NOTES \\
\hline
\end{tabular}




\section{I F E A D W O R K}

lion maravedís. On the death of her brother Garcilaso, she became the sole heir, although her mother left specific provision that she should make an allowance to her brother Fray Domingo, as long as he lived. ${ }^{1}$ Thus was the male line of Garcilaso wiped out, by war and by the Church, a fate which has overtaken so many Spanish families. From Doña Sancha's marriage with her cousin came the Counts of Monclova, a title which is today annexed to the Duchy of the Infantado. ${ }^{2}$

The fates were equally unkind with Lorenzo de Guzmán, the illegitimate son of the poet. While he was still a lad he incurred the wrath of the Emperor for having posted outside the church of San Pablo in Valladolid a Latin lampoon on various members of the Court. Charles $\mathrm{V}$ at first sentenced him and his cousin, a son of Pedro Laso who was also involved in the prank, to death, for a similar offense not long before had gone unpunished. On the intercession of his son Philip, he commuted this penalty to two years of

\section{A N D M O N O R A P H S}




\begin{tabular}{|c|c|}
\hline 166 & GARCILASO DE LA VEGA \\
\hline & $\begin{array}{l}\text { imprisonment and exile from Castile. }{ }^{1} \\
\text { Tamayo de Vargas cites from Agustin a } \\
\text { statement that he died on his way to Orán, } \\
\text { whither he was making his way in execu- } \\
\text { tion of this penalty. } \\
\text { On the death of Garcilaso at Nice his } \\
\text { body was placed in a Dominican monastery } \\
\text { in that city. }{ }^{2} \text { Two years later his wife had } \\
\text { it removed and brought to Toledo, where } \\
\text { it was placed in the ancestral tomb of the } \\
\text { lords of Batres in the church of San Pedro } \\
\text { Mártir, thus satisfying the complaint of } \\
\text { Sá de Miranda, } \\
\text { En esto, oh buen pastor, que te va a ti ? } \\
\text { El mal todo es de España } \\
\text { si enriquecen tus huesos tierra estraña. } \\
\text { Doña Elena rendered the accounting of her } \\
\text { husband's estate in I } 547 .^{4} \text { The inventory } \\
\text { of his personal effects has not been dis- } \\
\text { covered. Its loss is the more to be regret- } \\
\text { ted because from it we might have formed } \\
\text { some idea of the books which he possessed } \\
\text { and the ornaments which he had gathered } \\
\text { in his sojourn in Italy. We can gather }\end{array}$ \\
\hline & H I P A N I C N T E S \\
\hline
\end{tabular}




\section{LIFE AND WORKS}

167

but little from the list of debts which his wife settled, amounting to over a million maravedis, although it is interesting to find that he owed a hat-maker in Granada 250 ducats, a whole year's salary, and that he borrowed money in Naples from one of his fellow soldiers, a certain Captain Gerónimo. When Doña Elena made her first will, two years later, she mentions another debt which was still unpaid, the sum of three hundred scudi, which Garcilaso was said to have owed to a lady named Catalina de Sanseverino. ${ }^{1}$ If it be true that the fifth Canción of the poet was addressed to Catalina Sanseverino in the name of Mario Galeota, as his son-in-law told Herrera, ${ }^{2}$ then we must conclude that his verses brought credit to himself, if not favor to his friend. Under any circumstances it reveals a curious combination a prose and poetry.

Doña Elena de Guzmán survived until February 3, $5_{5} 6_{3} \cdot{ }^{3}$ In her second will. dated November 28, I $_{5} 62$, she mentions the figures of her husband and of her son

\section{A N D MONOGRAPHS}




\begin{tabular}{|c|c|}
\hline 168 & GARCILASO DE LA VEGA \\
\hline & $\begin{array}{l}\text { which she had had carved for their tomb } \\
\text { in San Pedro Mártir, and in a codicil, } \\
\text { signed on the eve of her death, she left or- } \\
\text { ders that a background (respaldar) should } \\
\text { be constructed and an inscription carved } \\
\text { by the painter Espinosa. At the same } \\
\text { time she provided for an alabaster bust of } \\
\text { herself to be placed with the other stat- } \\
\text { ues. }{ }^{1} \text { The remains of Garcilaso rested in } \\
\text { San Pedro Mártir for more than three- } \\
\text { centuries, until I } 869,^{2} \text { when they were ex- } \\
\text { humed and carried to Madrid to be placed } \\
\text { in the Panteón de Hombres Célebres. The } \\
\text { project for this memorial to the famous } \\
\text { sons of Spain having proved abortive, they } \\
\text { were brought back to Toledo and deposited } \\
\text { in the Ayuntamiento. During the annual } \\
\text { feria in I } 900 \text { they were once more returned } \\
\text { to the family tomb in the Capilla del } \\
\text { Rosario, as it is now called, in San Pedro } \\
\text { Mártir. The day of the ceremony was } \\
\text { celebrated by funeral services in the } \\
\text { Cathedral and by a solemn procession in } \\
\text { which the various civic organizations } \\
\text { marched in costumes of the sixteenth cen- }\end{array}$ \\
\hline & H I P A N I C N T E S \\
\hline
\end{tabular}




\section{LIFE A N D W ORK S}

tury. At the same time a tablet was set up on the wall of his ancestral home and the Calle de las Cadenas received the name of the Calle de Garcilaso de la Vega. ${ }^{1}$

The Chapel of the Rosary in San Pedro Mártir is at the right of the altar. Against the right hand wall as you enter stands the tomb of the Garcilasos. The stone facing at the back which his wife had planned was never built, but there is an inscription, though its date is recent: "Aquí están sepultados los restos del eximio vate toledano, Garcilaso de la Vega, exhumados en I869 para ser conducidos al Panteón Nacional. El amor de la Imperial Ciudad, representada por su Ayuntamiento, los restituyó a este sarcófago familiar, el día I 7 de Agosto de I900. D. E. P." On the sarcophagus are two kneeling figures in marble, representing father and son. $\mathrm{Al}^{-}$ though the two bearded knights in armor are almost identical, it is fairly certain that the figure nearer the altar represents the poet. Not only is it natural that the son would be placed behind the father,

\section{A N D MONOGRAPHS}




\begin{tabular}{|l|l|}
\hline GARCILASO DE LA VEGA \\
\hline $\begin{array}{l}\text { but the face of the statue in the rear is } \\
\text { plainly younger than that of the other. } \\
\text { As the poet was about thirty-five at the } \\
\text { time of his death, while his son was only } \\
\text { twenty-eight, we may be sure that the } \\
\text { noble head. which almost touches the side } \\
\text { of the altar is the image of the poet. We } \\
\text { do not know who was the sculptor who } \\
\text { carved the statues. The period at which } \\
\text { they were executed, after I555, makes it } \\
\text { certain that the likeness of Garcilaso was } \\
\text { taken from a portrait and not from life. } \\
\text { But as the only authentic portrait of the } \\
\text { poet it has unusual value. It is an im- } \\
\text { pressive head, with its high forehead and } \\
\text { deep-set eyes. Thehair is short and curly; } \\
\text { the beard half square. There is a singular } \\
\text { appeal in the grave, earnest face. Set in } \\
\text { the narrow niche, he still gazes with folded } \\
\text { hands at the little altar of the chapel, } \\
\text { alone, forgotten, unnoticed even by the } \\
\text { straggling worshipper who comes to leave } \\
\text { her tribute of flowers for the Virgin. }\end{array}$ \\
\hline H I S P A N I C N O T E S
\end{tabular}




\section{LIFE AND WORKS}

\section{CHAPTER XII \\ PERSONALITY}

It is curious that so little has come down to us which will help us to see Garcilaso, the man. As we have followed his life through the years, there has been hardly a glimpse of his whims, his weaknesses, his likes and dislikes, nor a mention of his personal appearance and disposition. The only contemporary observation on his character is a word of the jester, Francescillo de Zúniga, in the passage of his Crónica already referred to, in which he swears by "Pedro Laso's hope for favor and the gravity of his brother. "1 as subjects of current comment at the Court. This seriousness is characteristic of his writings; one looks in vain for a passing touch of humor or the suspicion of a smile. Our poet is utterly lacking in Horatian geniality. But he seems to have possessed a certain caustic type of observation, if we may believe the anecdotes which Zapata relates. ${ }^{2}$ Thus we hear that upon one occa-

\section{A N D MONOGRAPH S}




\begin{tabular}{|c|c|}
\hline 172 & GARCILASO DE LA VEGA \\
\hline & $\begin{array}{l}\text { sion, when he and the rest of the company } \\
\text { of the Duke of Alba were about to enter } \\
\text { an inn to eat, they found the doorway } \\
\text { blocked by the ill-mannered throng of } \\
\text { the suite of another great lord. Someone } \\
\text { called Garcilaso's attention to them and he, } \\
\text { turning around, said, "Go, accursed of my } \\
\text { father, for ye shall not enter into my king- } \\
\text { dom." Another of his stories contains a } \\
\text { punning verse of the poet.' It seems that } \\
\text { Garcilaso had been attended during an } \\
\text { illness by the Court physician, Francisco } \\
\text { López de Villalobos, and that on his re- } \\
\text { covery his gratitude had not been suff- } \\
\text { ciently concrete to induce him to pay for } \\
\text { his services. And so one day the doctor } \\
\text { sent a servant to dun him for his bill. Gar- } \\
\text { cilaso opened an empty chest (arca), took } \\
\text { out of it an empty purse and sent it to } \\
\text { him with this verse } \\
\text { La bolsa dice: yo vengo } \\
\text { como el arca do more, } \\
\text { que es el arca de Noë; } \\
\text { que quiere decir: no tengo. }\end{array}$ \\
\hline & H I P A N I N N TES \\
\hline
\end{tabular}




\section{IFE A N D W ORKS}

173

Concerning the personal appearance of the poet, we have no suggestion in the writers of his time. Herrera, writing almost half a century after his death, is frankly non-committal: "He was wellproportioned, for he was rather tall than of average height, and his features and bearing corresponded with his size."' But his later biographers, beginning with Tamayo de Vargas, allowed their fancy free play, until Wiffen was able to write, "His countenance, not without a shade of seriousness, was expressive of much mildness and benevolence; he had most lovely eyes, his forehead was expansive, and his whole appearance presented the picture of manly beauty." 2 In the second volume of the Parnaso español, published in $\mathrm{I} 770$, there appeared an engraving of a portrait of Garcilaso. Since then a number of portraits have been printed in different collections and editions of his works. ${ }^{3}$ All of these represented him as wearing the cross flory of Alcántara; all were apparently derived from the same painting or

\section{A N D MONOGRAP H S}




\begin{tabular}{|c|c|}
\hline 174 & GARCILASO DE LA VEGA \\
\hline & $\begin{array}{l}\text { from one another. When Fernández de } \\
\text { Navarrete published in I } 850 \text { the letter of } \\
\text { the Empress Isabella which definitely } \\
\text { named the poet as a knight of Santiago, } \\
\text { the evidence was available that the por- } \\
\text { trait of this gentleman of the Order of } \\
\text { Alcántara was not the portrait of the } \\
\text { Toledan poet. It remained however for } \\
\text { the Marquis of Laurencín to establish with } \\
\text { sound scholarship that the knight of Al- } \\
\text { cántara is actually a Garcilaso de la Vega, } \\
\text { but another Garcilaso, namely his nephew, } \\
\text { son of Pedro Laso, whose projected mar- } \\
\text { riage with Dona Isabel de la Cueva was } \\
\text { the source of his uncle's imprisonment. } \\
\text { For this Garcilaso, in spite of the long con- } \\
\text { tinued disfavor of Charles V, became dis- } \\
\text { tinguished as an ambassador under Philip } \\
\text { II and was Comendador de Belvis y Nava- } \\
\text { rra in the Order of Alcántara. The re- } \\
\text { searches of the Marquis of Laurencín have } \\
\text { also demonstrated the futility of the efforts } \\
\text { of Justi to identify a portrait in the Kas- } \\
\text { sel Gallery as a likeness of the poet, }{ }^{3} \text { for } \\
\text { this work of the school of Bronzino also }\end{array}$ \\
\hline & H I P A N I C NOTES \\
\hline
\end{tabular}




\section{I F E A N D W O R S}

shows a gentleman wearing the green cross of Alcántara. The statue in the chapel of San Pedro Mártir therefore remains the only work which was assuredly intended to represent Garcilaso de la Vega, "the Prince of Castilian poets.'

Little as his contemporaries have to tell us of Garcilaso, his own works offer no more of a picture of his temperament. So large a portion of them is purely formal verse, impersonal as was so much of the Italian poetry of the Cinquecento, that we should try in vain to reconstruct from them a character. But in regretting this lack of precise information concerning the poet, we must remember that he died before he was thirty-five and that prior to his death the only work from his pen to be published was the letter included in the r 534 edition of Boscán's translation of $\mathrm{Il}$ cortegiano. Nor must it be overlooked that his literary production was not the leisurely expression of a pensioned laureate, but the hasty composition of a man of the world, stolen, as he himself says, from his

\section{A N D MONOGRAPH S}




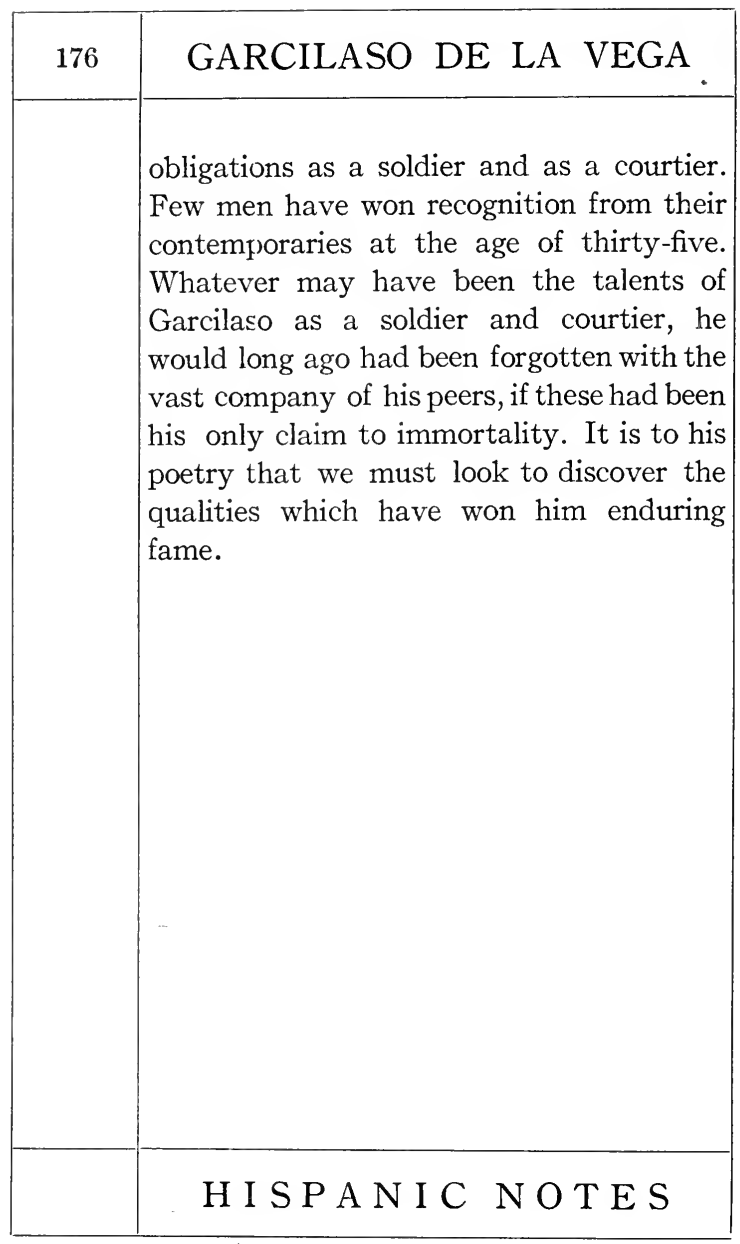





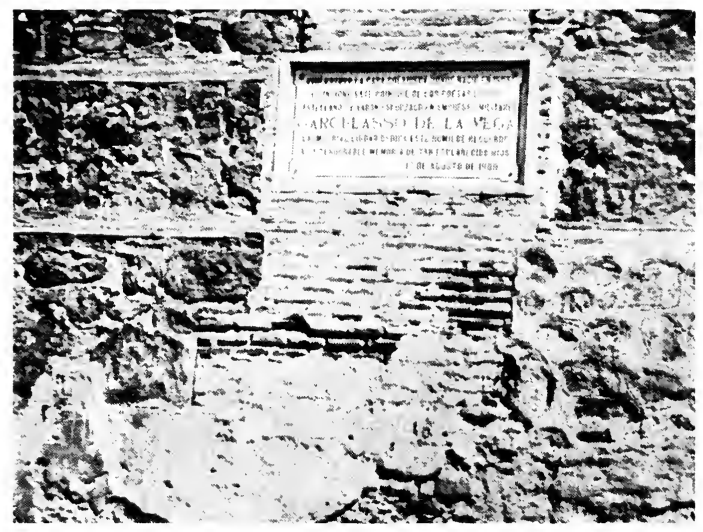

Memorial Tablet on Garcilaso's Birthplace 


\section{PART II WORKS}





\section{GARCILASO DE LA VEGA}

\section{CHAPTER I \\ SPANISH TERSES}

During Garcilaso's lifetime only one of his works was published, the Dedicatory Epistle to the edition of Boscán's translation of $I l$ cortegiano, printed in 1534 . But his talent must have been known, to a certain extent, at least, among his contemporaries through manuscript copies of his poems; perhaps the suelto, bearing the date I536, which contains the sonnet "Passando el mar Leandro el animoso" (No. XXIX) was printed even before his death. The scattered papers of the poet were gathered by his family and intrusted to the care of his friend Boscán, who was preparing them for publication together with his own verses, when he too was surprised by death. Boscán's widow determined, however, to carry out her husband's purpose; in $\mathrm{I} 5+3$ the press of Carles Amoros in Barcelona produced a quarto

\section{H I S P A N I NOTES}




\begin{tabular}{|c|c|}
\hline 180 & GARCILASO DE LA VEGA \\
\hline & $\begin{array}{l}\text { volume intitled: "Las obras de Boscan } \\
\text { y algunas de Garcilasso de la Vega, reparti- } \\
\text { das en quatro libros." The publisher in a } \\
\text { brief note "A los lectores" explained the } \\
\text { circumstances which had affected the } \\
\text { publication of the work, adding that, de- } \\
\text { spite any imperfections which it might } \\
\text { Ieveal for lack of the polish which Bos- } \\
\text { cán's hand would have given it, he had } \\
\text { printed the text as he had found it, } \\
\text { for no one would be so bold as to under- } \\
\text { take to emend the works of Boscán nor } \\
\text { those of Garcilaso. } \\
\text { The works of Garcilaso, all in the Italian } \\
\text { measures, comprised the Fourth Book of } \\
\text { the volume, - twenty-eight sonnets, five } \\
\text { canciones, two elegies, an epistle and three } \\
\text { eclogues. At the front of the volume on } \\
\text { an inserted sheet appeared another son- } \\
\text { net (No. XXIX), "which they forgot to } \\
\text { put at the end with his works," and among } \\
\text { the verses which formed the First Book of } \\
\text { Boscán's works in the Castilian measures, } \\
\text { was included a villancico of Garcilaso on } \\
\text { the theme: }\end{array}$ \\
\hline & H I P A N I C NOTES \\
\hline
\end{tabular}




\section{LIFE AND WORKS}

Que testimonios son estos, que le quereys levantar, que no fue sino baylar? ${ }^{1}$

Rarely has a book of verse enjoyed a greater popularity than did this monument to the lifelong friendship of the two poets; before the end of the century no less than twenty-one editions were printed, including editions made in Italy, France, Portugal and Flanders, and of these, sixteen

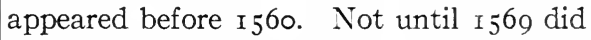
there appear an edition of the works of Garcilaso alone, when there was printed at Salamanca a slight volume containing the compositions which had been included in the editions of Boscán's works, with the exception of the villancico. In $\mathrm{I}_{574}$ the eminent humanist, Francisco Sánchez de las Brozas, printed at Salamanca the first edition of Garcilaso's works with a commentary. In addition to the works included in the edition of 1569 he printed several other compositions, - six sonnets and five coplas. The second edition (I577) contained three more sonnets "at-

\section{A N D MONOGRAPH S}




\begin{tabular}{|c|c|}
\hline 182 & GARCILASO DE LA VEGA \\
\hline & $\begin{array}{l}\text { tributed to Garcilaso, from a manuscript." } \\
\text { Since that date the only authentic works } \\
\text { of the poet which have been discovered } \\
\text { are two coplas, found in the Biblioteca } \\
\text { Nacional in Madrid; two autograph let- } \\
\text { ters, preserved at Naples and at Simancas, } \\
\text { and finally, of far greater moment, three } \\
\text { of his Latin poems, now in the libraries of } \\
\text { Naples and Madrid. }{ }^{1} \text { It is probable that } \\
\text { he left other works which have disappeared } \\
\text { or which may still be buried in some pro- } \\
\text { vincial or family library. Luis Briceno, } \\
\text { the publisher of the edition of I6 } 626 \text {, men- } \\
\text { tions specifically a copy of some still un- } \\
\text { published works, which was presented by } \\
\text { his son, Pedro de Guzmán, to the March- } \\
\text { ioness of Almenara, but which the printer, } \\
\text { to whom they had been given for publica- } \\
\text { tion, had failed to publish and refused to } \\
\text { show to him. The loss of these works is } \\
\text { lamentable; yet at least we possess those } \\
\text { of his poems which he himself felt worthy } \\
\text { of preservation. Slight as is their bulk, } \\
\text { they are ample to reveal his singular } \\
\text { talents. Let us turn to their study. }\end{array}$ \\
\hline & H I P A N I C NOTES \\
\hline
\end{tabular}




\section{IF E A N D W O R K}

\section{A. VERSES IN THE CASTILIAN MEASURES}

Throughout the reign of Ferdinand and Isabella and the first decade of that of Charles $\mathrm{V}$, the fashion of writing facile, occasional verse had flourished at the Court with all the success which it had enjoyed under Henry IV; the gallant gentlemen of the time continued to exercise their wits in celebrating the petty events of their daily life in redondillas and quintillas. This school of verse, which fills the cancioneros of the fifteenth century, is epitomized in the Cancionero general of Hernando del Castillo of $\mathrm{I} 5 \mathrm{II}$, increased in each subsequent edition by the addition of examples of contemporary compositions. At best it is a graceful vers de société; at worst it is the drivel of an empty spirit. It was in this school that Garcilaso made his first essays in the field of poetry.

The eight little pieces which have survived to illustrate his efforts do not rise above the level of the time. Any or all of them could as well be the work of one of the named or unnamed authors of the

\section{A N D M O N G R A H S}




\begin{tabular}{|c|c|}
\hline 184 & GARCILASO DE LA VEGA \\
\hline & $\begin{array}{l}\text { Cancionero general. The occasions which } \\
\text { inspired them are typical: "To Luis de la } \\
\text { Cueva, because he danced at Court with } \\
\text { a lady whom they called "The Bird';" "To } \\
\text { Boscán, because in Germany he danced at } \\
\text { a wedding;" "On a Departure;" "To Isabel } \\
\text { Freyre, because she married a man out } \\
\text { of her circle;" "To Doña Mencia de la } \\
\text { Cerda, who gave him a net and said that } \\
\text { she had woven it that day." Verses of this } \\
\text { sort do not in reality make any pretension } \\
\text { to being poetry. They are merely exer- } \\
\text { cises in ingenuity, intended to give a dainty } \\
\text { setting to a bit of badinage, a compliment } \\
\text { or idle jest. All too often they are a mere } \\
\text { subtle juggling of words or an enlargement } \\
\text { on a paradox. } \\
\text { Be it said that the coplas of Garcilaso } \\
\text { are the equal of any of the type in the only } \\
\text { qualities to which it may claim merit, that } \\
\text { is, in gracefulness and musical cadence. In } \\
\text { this respect there is a particular charm in } \\
\text { the little letrilla, } \\
\text { Nadi puede ser dichoso, } \\
\text { señora, ni desdichado, }\end{array}$ \\
\hline & H I P A N I NOTES \\
\hline
\end{tabular}




\section{LIFE A N D WORKS}

sino que os haya mirado;

porque la gloria de veros

en ese punto se quita

que se piensa mereceros.

Asi que, sin conoceros, nadi puede ser dichoso, señora, ni desdichado, sino que os haya mirado. -

(Copla VIII)

Among the coplas printed by El Brocense in ${ }^{574}$ is one "Translating four lines of Ovid. (No. V). It is doubtful whether the verse is properly attributed to Garcilaso, for an almost identical version of the passage is found as the work of Diego Hurtado de Mendoza in several manuscripts and in the first edition of his poems. ${ }^{1}$ If the translation is really Garcilaso's, it is interesting as revealing an early interest in Ovid and also because another Garcilaso de la Vega, probably the poet's son, has left a sonnet on the same theme.

There is no way of establishing precise dates for any of these early verses of the

\section{A N D MONOGRAPH S}




\begin{tabular}{|c|c|}
\hline 186 & GARCILASO DE LA VEGA \\
\hline & $\begin{array}{l}\text { poet. But it is probable that they were } \\
\text { all written before his residence in Naples } \\
\text { beginning in } 1532 \text {. The copla on the mar- } \\
\text { riage of Isabel Freyre was certainly com- } \\
\text { posed, as we have seen, as early as } 1529 \text {, } \\
\text { and the verse mocking Luis de la Cerda } \\
\text { must have been written before I } 53 \text { I, for } \\
\text { the old Duke of Alba, who died in that } \\
\text { year, is one of his fellow jesters. Menéndez } \\
\text { y Pelayo is inclined to place Boscán's visit } \\
\text { to Germany and the dancing exploit which } \\
\text { Garcilaso celebrates in I } 532{ }^{1} \text { but it is more } \\
\text { probable that the event belongs to the } \\
\text { early part of the Emperor's visit in the } \\
\text { summer of I } 530 \text {, for Garcilaso does not } \\
\text { mention Boscán as with him on the trip } \\
\text { to Ratisbonne in I } 53^{2} \text {. Perhaps some of } \\
\text { them were written as early as I } 525 \text { or } \\
\text { I } 526 \text {. Whatever were their dates, it is } \\
\text { at least certain that Garcilaso never at- } \\
\text { tained the reputation as a writer of coplas } \\
\text { which Boscán enjoyed as early as I } 530 .{ }^{2} \\
\text { He was no more distinguished in this ac- } \\
\text { complishment than any well-bred gentle- } \\
\text { man of the Court. }\end{array}$ \\
\hline & H I P A N I N N T E S \\
\hline
\end{tabular}




\section{LIFE AND WORKS}

B. VERSES IN THE ITALIAN MEASURES

That Garcilaso did not derote himself to the cultivation of his native form of verse is due to another event, that historic conversation between Boscán and Andrea Navagero at Granada in I526. We have seen how the Venetian ambassador persuaded the Spanish poet to endearor to acclimate in Castile the measures of $\mathrm{Pe}$ trarch and how the latter's failing enthusiasm in this new venture was rekindled by the advice and emulation of his friend Garcilaso. It is difficult to form a judgment as to the exact date at which Garcilaso first began his experiments in the Italian measures. The first of his poems in the new style to which it is possible to attach a definite date is the cancion (No. III) written on the island in the Danube in the summer of I532. When we consider the mastery of form which this cancion reveals, it is at once apparent that its author is no novice in the field and it is probable that a number of his sonnets and canciones were written before that date, perhaps as early

\section{A N D M O N O G A P H S}




\begin{tabular}{|c|c|}
\hline 188 & GARCILASO DE LA VEGA \\
\hline & $\begin{array}{l}\text { as I } 528 \text {. Certain hesitations in the use of } \\
\text { the hendecasyllable make it probable that } \\
\text { his earliest poems are the sonnets which } \\
\text { head his works in the first edition; in } \\
\text { fact, there is reason for believing that all } \\
\text { the poems there printed are arranged in } \\
\text { a roughly chronological order. We shall } \\
\text { therefore be justified in studying the dif- } \\
\text { ferent forms which he utilized in the } \\
\text { sequence in which they originally appeared, } \\
\text { tracing the development of his art from } \\
\text { the sonnets through the elegies to the ec- } \\
\text { logues which were his crowning achieve- } \\
\text { ment. } \\
\text { I. THE sonNETs AND cANCIONEs. } \\
\text { Quando me paro a contemplar mi estado, } \\
\text { Garcilaso begins his first sonnet, recalling } \\
\text { the opening of a sonnet of Petrarch, } \\
\text { Quand'io mi volgo in dietro a mirar gli anni; } \\
\text { (Son. CCLVII) } \\
\text { Petrarchan is the influence paramount in } \\
\text { all of his first essays in the sonnet and } \\
\text { cancion. There can be little doubt that } \\
\text { it was Navagero who encouraged both }\end{array}$ \\
\hline & H I P A N I N N T E S \\
\hline
\end{tabular}




\section{IFE A N D W ORK S}

Boscán and Garcilaso to take him as their model; perhaps it was he who gave them their first copy of Il canzoniere. To Petrarch Garcilaso is indebted not merely for his measure, but for his whole artistic technique; Petrarchan is his choice of theme, - a mood or moment of amorous experience; Petrarchan, the analysis of the emotions and the subtle, often too subtle, contrasts; Petrarchan, finally, the spiritual attitude of melancholy, half-bitter, halftender, in the presence of a love that can never be realized.

If the opening line of this first sonnet suggests the source of Garcilaso's early inspiration, the remainder of the poem reveals with equal clarity his process of imitation. For in reality the sonnet is in no sense an imitation of the Italian work which begins with the same thought. After the first two lines its development is wholly original. The poet has fashioned out of a reminiscence a new work, following a new train of thought. And this method is characteristic of all Garcilaso's

\section{A N D M O N O G R P H S}




\begin{tabular}{|c|c|}
\hline 190 & GARCILASO DE LA VEGA \\
\hline & $\begin{array}{l}\text { sonnets; there are frequent reminiscences } \\
\text { of Petrarch, both verbal and general; } \\
\text { there is not one which as a whole may be } \\
\text { called an imitation of any individual son- } \\
\text { net of the Italian poet. } \\
\text { A second phase of his early imitation is } \\
\text { also manifest in this same sonnet: a } \\
\text { tendency to adopt the highly artificial } \\
\text { style with its balanced contrasts, its com- } \\
\text { plicated juggling with ideas or even words, } \\
\text { and its preference for conceits to emotions. } \\
\text { That Garcilaso should have endeavored to } \\
\text { copy this weakness of Petrarch is not } \\
\text { strange. The mannerisms of great artists } \\
\text { are always easier to imitate than the true } \\
\text { qualities of their genius, and it is only } \\
\text { necessary to read the works of his Italian } \\
\text { contemporaries, such as Angelo di Cos- } \\
\text { tanzo or Bernadino Rota, to realize that } \\
\text { Garcilaso's error was one common to his } \\
\text { time, despite the puristic attempts of } \\
\text { Bembo. Moreover, the poetry with which } \\
\text { he must have been most familiar in his own } \\
\text { Castilian, the verses of the Cancioneros, } \\
\text { suffered acutely from the same malady. }\end{array}$ \\
\hline & H I P A N I C N T E S \\
\hline
\end{tabular}




\section{I F E A N D W O R K}

There was every reason, then, for him to have mistaken the means for the end, and when we consider that he was working in a form with which he was unfamiliar, it is surprising that he so often avoided the pitfalls and attained an accent of ardent sincerity.

How unfamiliar the form was to him, is at once apparent. There is in his sonnets and canciones little of that polished elegance and musical mastery which gives $I l$ canzoniere of Petrarch its most enduring charm. The lines are often metrically faulty, both in number of syllables and in stress. Even in those which are technically correct there is an awkardness and a lack of flowing rhythm. More striking still as an evidence of his inexperience is the inequality of his diction. An admirable beginning is marred by an ending of hopeless weakness, or again, a struggling, limping sonnet is redeemed by a brilliant closing tercet. But these occasional quatrains and tercets, even a few whole sonnets, which stand out by reason of their perfec-

\section{A N D M O N O G A P H S}




\begin{tabular}{|c|c|}
\hline 192 & GARCILASO DE LA VEGA \\
\hline & $\begin{array}{l}\text { tion of expression, give promise of that } \\
\text { mastery of form which was eventually to } \\
\text { be his chief distinction. } \\
\text { Garcilaso did not give to his sonnets and } \\
\text { canciones that real or fictitious unity which } \\
\text { Petrarch's careful revision was able to im- } \\
\text { part to his Canzoniere. They appear as } \\
\text { the scattered expression of his brief career, } \\
\text { offering us glimpses of his loves, his friend- } \\
\text { ships, or his reading. And yet it is pos- } \\
\text { sible to trace in them certain phases of his } \\
\text { experience and to reconstruct in some } \\
\text { measure the story of his heart. } \\
\text { The poetic life of the poet is divided into } \\
\text { two parts; the first, the story of his love } \\
\text { for Isabel Freire, the second, the picture } \\
\text { of a new and very different passion in } \\
\text { Naples. Let us attempt to follow his story } \\
\text { through his poems. We have seen already } \\
\text { the circumstances under which Isabel } \\
\text { Freire came into his life; to her was } \\
\text { dedicated, we know, the copla, "Culpa deve } \\
\text { ser quereros," and it is probable that } \\
\text { several of his other verses in the Castilian } \\
\text { measures were addressed to her (as Coplas }\end{array}$ \\
\hline & H I S A N I C NOTES \\
\hline
\end{tabular}




\section{LIFE A N D WORKS}

III, IV, and VIII). ${ }^{1}$ Garcilaso was already married, it is true, but his position as gentleman of the Emperor's household kept him at Court, apart from his wife, and no doubt in constant company with the lady-in-waiting of the Empress, Dona Isabel. That his love for her was intense and sincere is revealed in every line of his works which mentions her; indeed it is often this quality of sincerity which distinguishes his real poetry from his imitative verses.

His first experiments in the new style belong early in his acquaintance with Dona Isabel; under these circumstances it is natural that they should have been addressed to her, the more so, in that his relation to his beloved was precisely that of Petrarch to Laura, a love that could never be requited. Thus we find in the first two sonnets a picture of his despair: he has given himself to her and she is scornful; the only remedy is death. This, too, is the mood of the first two canciones, which make clear the completeness of his

\section{A N D MONOGRAPHS}




\begin{tabular}{|c|c|}
\hline 194 & GARCILASO DE LA VEGA \\
\hline & $\begin{array}{l}\text { surrender, the bitterness and pain which } \\
\text { her indifference causes him. It is she who } \\
\text { has filled his life, he declared in the sonnet, }\end{array}$ \\
\hline & Escrita esta en mi alma vuestro gesto; (V) \\
\hline & her love has wholly possessed him, \\
\hline & $\begin{array}{l}\text { Yo no naci sino para quereros; } \\
\text { mi alma os ha cortado a su medida, } \\
\text { por abito del alma misma os quiero; } \\
\text { (lines } 9-11 \text { ) }\end{array}$ \\
\hline & and if he is absent from her, life is not life: \\
\hline & $\begin{array}{l}\text { Señora mia, si yo de vos ausente } \\
\text { en esta vida turo y no me muero, } \\
\text { pareceme que offendo a lo que os quiero } \\
\text { y la bien de que gozava en ser presente. } \\
\text { (Son. IX, 1-4) }\end{array}$ \\
\hline & $\begin{array}{l}\text { The marriage of Dona Isabel to } \\
\text { Antonio de Fonseca late in I } 528 \text { or early } \\
\text { in I } 529 \text { brought a radical change in Gar- } \\
\text { cilaso's attitude toward her. If, before, his } \\
\text { pleas were unavailing in the presence of } \\
\text { her scorn or indifference, there was at } \\
\text { least the hope that she might have mercy } \\
\text { on his suffering. Now her love was doubly }\end{array}$ \\
\hline & H I PAN IC NOTES \\
\hline
\end{tabular}




\section{LIFE AND WORKS}

impossible. Although the feelings of the poet are most clearly depicted in the protests of Salicio in Egloga I, there are numerous evidences of his dejection in his earlier verses. Peculiarly appealing is the close of the sonnet in which he reviews the course of his love:

Y sobre todo, faltame la lumbre

de la esperança, con que andar solia por la oscura region de vuestro olvido.

(Son. XXXVIII, 12-14)

In the summer of 1529 Garcilaso made his first visit to Italy in the suite of Charles $V$. But the memory of Dona Isabel was still harassing him; from a foreign shore he cries his despair:

La mar en medio y tierras he dexado de quanto bien, cuytado, yo tenia.

(Son. III, 1-2)

Perhaps it was at this time that he first read some of the verses of Dante in the Florentine edition of the Rime antiche of ${ }^{1} 5^{27}$ and developed the lines of the canzone, "Donne ch'avete intelletto d'amore,"

\section{A N D M O N G R A H S}




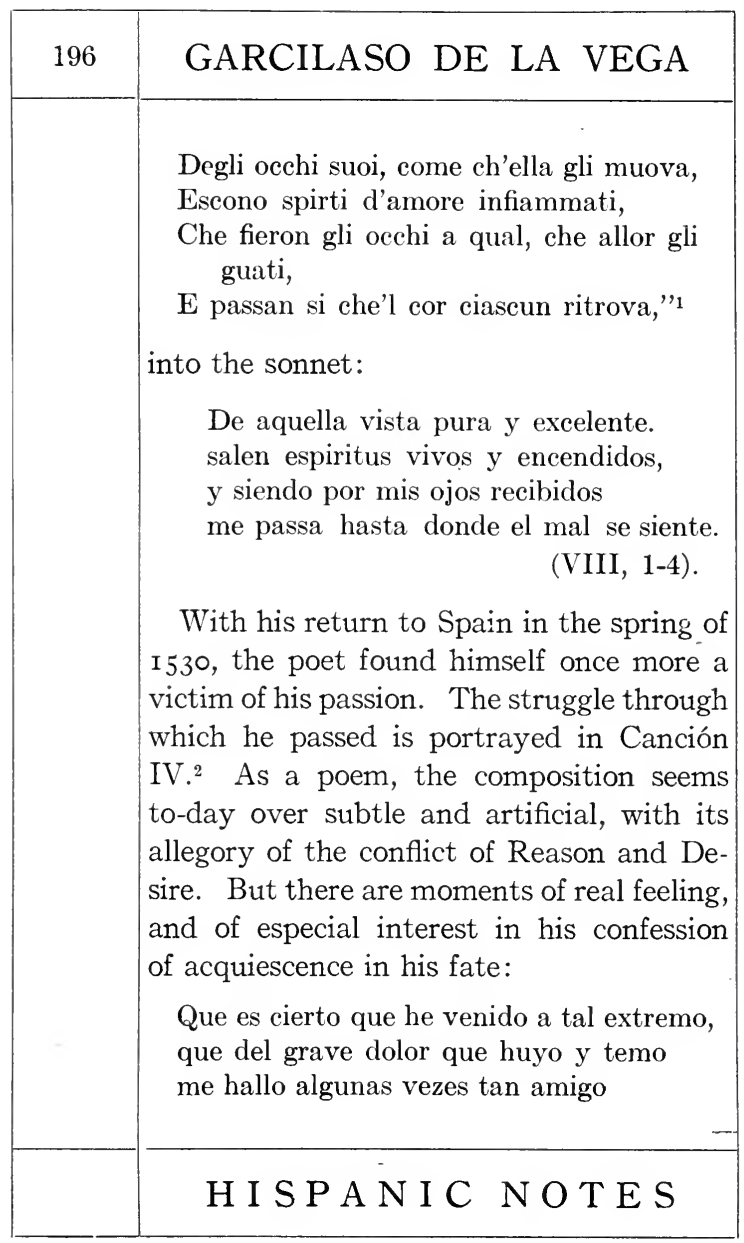




\section{LIFE AND WORKS}

que en medio del, si buelvo a ver la vida de libertad, la juzgo por perdida, y maldigo las oras y momentos, gastadas mal en libres pensamientos.

(lines 11t-120)

There is a passage in Egloga II, in which Nemoroso is proclaiming the diverse powers of Severo, which forms a pendant to these lines. Nemoroso, relating his visit to the latter, says that at first Severo was silent,

Y luego con boz clara $y$ espedida solto la rienda al verso numeroso, en alabança de la libre vida.

Yo estava embevecido y vergonçoso, atento al son, $y$ viendome del todo fuera de libertad y de reposo.

No se dezir, sino que en fin, de modo aplico a mi dolor la medicina, quel mal desarraygo de todo en todo.

Quede yo entonces como quien camina de noche por caminos enrriscados, sin ver donde la senda o passo inclina;

mas venida la luz y contemplados, del peligro passado nace un miedo que dexa los cabellos herizados.

\section{A N D MONOGRAPHS}




\begin{tabular}{|c|c|}
\hline 198 & GARCILASO DE LA VEGA \\
\hline & $\begin{array}{l}\text { Assi estava mirando atento y quedo } \\
\text { aquel peligro yo que atras dexava, } \\
\text { que nunca sin temor pensallo puedo. } \\
\text { Tras esto, luego se me presentava } \\
\text { sin antojos delante la vileza } \\
\text { de lo que antes ardiendo desseava. } \\
\text { Assi curo mi mal con tal destreza } \\
\text { el sabio viejo, como te he contado, } \\
\text { que bolvio el alma a su naturaleza } \\
\text { y solto el corazon aherrojado. } \\
\text { (lines 1104-28) } \\
\text { It it not necessary to attach too literal } \\
\text { a significance to Nemoroso's confession, } \\
\text { but it seems certain that the poet felt a } \\
\text { sort of spiritual discomfort at his situa- } \\
\text { tion, a shame which is also manifested in } \\
\text { another passage of Canción IV: } \\
\text { De los cabellos de oro fue texido } \\
\text { la red que fabrico mi sentimiento, } \\
\text { do mi razon, rebuelta y enredada, } \\
\text { con gran verguença suya y corrimiento, } \\
\text { subjeta al apetito y sometida, } \\
\text { en publico adulterio fue tomada, } \\
\text { del cielo y de la tierra contemplada. } \\
\text { (lines 101-7) }\end{array}$ \\
\hline & H I PANIC NOTES \\
\hline
\end{tabular}




\section{LIFE A N D WORKS}

At least we may be sure that he reached a crisis in his relations with Doña Isabel, for the few subsequent references to her prior to her death are almost conventional and his misfortune in losing her is coupled with another misfortune, his loss of the Emperor's favor. Canción III, the most perfect of his songs in the Petrarchan style, turns upon this double theme. Apart from its exquisiteness of form this cancion is significant for the glimpse it offers, one of the few in his works, of the character of the poet, in the finely defiant lines,

\section{¿Y al fin de tal jornada}

presumen de espantarme?

Sepan que ya no puedo

morir, sino sin miedo;

que aun nunca que temer quiso dexarme la desventura mia,

que el bien y el miedo me quito en un dia.

(lines46-52)

Closely akin, in their atmosphere of gloom at the reversal of fortune are two sonnets (IV and XXVI), almost identical in their

\section{A N D MONOGRAPHS}




\begin{tabular}{|c|c|}
\hline 200 & GARCILASO DE LA VEGA \\
\hline & $\begin{array}{l}\text { content and phraseology, each closing with } \\
\text { a renewed expression of desire to see once } \\
\text { more his beloved. } \\
\text { The news of Doña Isabel's death must } \\
\text { have reached the poet at Naples early in } \\
\text { I } 533 \text {. All his old love for her was rekindled, } \\
\text { and to it and to his grief he gave vent in } \\
\text { the noblest of his works, Eclogue I, and in } \\
\text { a sonnet, the most perfect of his shorter } \\
\text { poems in the delicate harmony of emotion } \\
\text { and expression: } \\
\text { ¡O dulces prendas, por mi mal falladas, } \\
\text { dulces y alegres, quando Dios queria! } \\
\text { Juntas estays en la memoria mia, } \\
\text { y con ella en mi muerte conjuradas. } \\
\text { ¿Quien me dixera, quando las passadas } \\
\text { oras que en tanto bien por vos me via, } \\
\text { que me aviades de ser en algun dia } \\
\text { con tan grave dolor representadas? } \\
\text { Pues en una ora junto me llevastes } \\
\text { todo el bien que por terminos me distes, } \\
\text { llevame junto el mal que me dexastes; } \\
\text { sino, sospechare que me pusistes } \\
\text { en tantos bienes, porque desseastes } \\
\text { verme morir entre memorias tristes. (X) }\end{array}$ \\
\hline & H I P A N I NOTES \\
\hline
\end{tabular}




\section{I F E A N D W O R K S}

In April he was in Spain on a mission of the Emperor from the Vice-roy of Naples. Perhaps it was on this visit that he visited her tomb and wrote the touching sonnet:

¡O hado esecutivo en mis dolores, como senti tus leyes tan rigurosas! Cortaste el arbol con manos dañosas $\mathrm{y}$ esparziste por tierra fruta $\mathrm{y}$ flores.

En poco espacio yazen los amores y toda la esperança de mis cosas, tornados en cenizas desdeñosas $\mathrm{y}$ sordas a mis quexas y clamores.

Las lagrimas que en esta sepultura se vierten oy en dia y se vertieron recibe, aunque sin fruta alla te sean;

hasta que aquella eterna noche escura me cierre aquestos ojos que te vieron, dexandome con otros que te vean. (XXV)

Once more in his last work, Eclogue III, he refers to her death with a tenderness and pathos which reveal the healing touch of time, in his description of the scene embroidered by the nymph Nise (lines 225264).

\section{A N D MONOGRAPH S}




\begin{tabular}{|c|c|}
\hline 202 & GARCILASO DE LA VEGA \\
\hline & $\begin{array}{l}\text { The love of Garcilaso for Isabel Freire } \\
\text { permeates his work from beginning to } \\
\text { end; it is she who inspired all of his verses } \\
\text { which still have power to move and charm } \\
\text { his readers. She is no disembodied crea- } \\
\text { tion of the poet's fancy, but a woman of } \\
\text { flesh and blood, desired ardently, reck- } \\
\text { lessly, as men desire women. And although } \\
\text { that desire was never fulfilled, perhaps be- } \\
\text { cause it was never fulfilled, there burns in } \\
\text { his verses to her an unwaning intensity } \\
\text { which thrills you like the song of a meadow- } \\
\text { lark at dusk. Even in death he reaches } \\
\text { out to her, not as Dante to an angelic } \\
\text { Beatrice nor as Petrarch to a rarefied } \\
\text { Laura, but as to his eternal heart's desire. } \\
\text { Perhaps the most human touch in all his } \\
\text { work is this infinite yearning for an ulti- } \\
\text { mate union with her, expressed in the clos- } \\
\text { ing lines of the sonnet written at her tomb } \\
\text { and with even more beauty at the end } \\
\text { of Nemoroso's lament: } \\
\text { Divina Elisa, pues agora el cielo } \\
\text { con immortales pies pisas y mides, } \\
\text { y su mudanca ves, estando queda, }\end{array}$ \\
\hline & H I S A N IC NOTES \\
\hline
\end{tabular}




\section{IFE A N D WORK S}

¿por que de mi te olvidas y no pides que se apresure el tiempo en que este velo rompa del cuerpo y verme libre pueda? $\mathrm{Y}$ en la tercera rueda contigo mano a mano busquemos otro llano, busquemos otros montes y otros rios, otros valles floridos $\mathrm{y}$ sombrios, donde descansar y siempre pueda verte ante los ojos mios, sin miedo $y$ sobresalto de perderte.

(Egl. I, 394-407)

In his Ode to Tilesio, Garcilaso hints at the loneliness which the first days of his exile in Naples had brought, but declares that that stage has passed, that once more his lips are moved to sing the beauties of his new surroundings. The influence of his stay in Naples is manifested in many ways in his work. With the new contact with the poets and the literature of the Neapolitan court, he enlarged his conception of the lyric and from now on, we find other influences in his verse than that of Petrarch.

\section{A N D MONOGRAPHS}




\begin{tabular}{|c|c|}
\hline 204 & GARCILASO DE LA VEGA \\
\hline & $\begin{array}{l}\text { The writings of Sannazaro and the ex- } \\
\text { ample of Tansillo aroused his latent love } \\
\text { of nature. In all the early works written } \\
\text { in Spain there is only one glimpse of the } \\
\text { natural world, and that is but a gloomy } \\
\text { prospect: }\end{array}$ \\
\hline & $\begin{array}{l}\text { Los arboles presento } \\
\text { entre las duras peñas } \\
\text { por testigo de quanto os he encubierto. } \\
\text { (Canc. II, 26-28) }\end{array}$ \\
\hline & $\begin{array}{l}\text { Already, however, in the cancion written } \\
\text { during his confinement on the island in the } \\
\text { Danube we find a brief evidence of delight } \\
\text { in out-doors, }\end{array}$ \\
\hline & $\begin{array}{l}\text { Do siempre primavera } \\
\text { parece en la verdura } \\
\text { sembrada de las flores; } \\
\text { hazen los ruyseñores } \\
\text { renovar el plazer o la tristura } \\
\text { con sus blandas querellas, } \\
\text { que nunca dia ni noche cessan dellas. } \\
\text { (Canc. III, 7-13) }\end{array}$ \\
\hline & $\begin{array}{l}\text { With his establishment in Naples the por- } \\
\text { trayal of the beauties of nature becomes a }\end{array}$ \\
\hline & H I P A N I C NOTES \\
\hline
\end{tabular}




\section{LIFE A N D W ORK S}

characteristic of his style, an idealized, conventionalized nature, it is true, but one of infinite charm.

A second phase of his work in Naples is the introduction of themes from classical mythology as the subject of his sonnets and canciones. More important still as a sign of growth is the heightened plastic and pictorial power, the atmosphere of assurance, of complete mastery of form which atones in his later work for the lack of emotional sincerity. All of these qualities are evident in the sonnet,

Hermosas nymphas, que en el rio metidas. contentas habitays en las moradas de reluzientes piedras fabricadas, $\mathrm{y}$ en colunnas de vidrio sostenidas, agora esteys labrando embevescidas o texendo las telas delicadas; agora unas con otras apartadas, contandoos los amores $\mathrm{y}$ las vidas;

dexad un rato la labor, alçando vuestras rubias cabeças a mirarme, y no os detendreys mucho segun ando, que, o no podreys de lastima escucharme,

\section{A N D MONOGRAPHS}




\begin{tabular}{|c|c|}
\hline 206 & GARCILASO DE LA VEGA \\
\hline & $\begin{array}{l}\text { o convertido en agua aqui llorando, } \\
\text { podreys alla de espacio consolarme. (XI) } \\
\text { The scene and its details are derived from } \\
\text { a canzone (XI) of Sannazaro and from a } \\
\text { passage in the Arcadia; the purpose of the } \\
\text { poem is no longer to reveal a state of mind, } \\
\text { but to create a thing of beauty, com- } \\
\text { pounded of imaginary details, it is true, } \\
\text { yet achieving its purpose by the mere } \\
\text { color and music of its phrases. For a } \\
\text { moment in the closing lines there is a sign } \\
\text { of hesitancy, of reversion to the earlier } \\
\text { style, with its lament and paradoxical } \\
\text { alternatives, a weakness found also in the } \\
\text { sonnet on the Orpheus story (XV). But } \\
\text { we find the poet wholly emancipated in the } \\
\text { sonnet: } \\
\text { A Daphne ya los braços le crecian } \\
\text { y en luengos ramos bueltos se mostravan; } \\
\text { en verdes hojas vi que se tornavan } \\
\text { los cabellos quel oro escurezian. } \\
\text { De aspera corteza se cubrian } \\
\text { los tiernos miembros que aun bullendo } \\
\text { estavan; }\end{array}$ \\
\hline & H I P A N I N OTES \\
\hline
\end{tabular}




\section{LIFE A N D W R K}

los blandos pies en tierra se hincavan $\mathrm{y}$ en torcidas rayzes se bolvian.

Aquel que fue la causa de tal daño a fuerça de llorar crecer hazia este arbol, que con lagrimas regava.

¡O miserable estado! 10 mal tamaño! que con llorarla crezca cada dia la causa y la razon por que llorava. (XIII)

His story is derived from Ovid, not from Petrarch. Out of a timeworn myth he has refashioned a work of real beauty. And this same mastery of form and matter is visible in the sonnets on Spring (XXIII) and on Leander (XXIX).

Unquestionably his most perfect work in this style is his last canción, or as it is properly called, the "Ode to the Flower of Gnido." The form is a new one, borrowed from Bernardo Tasso, who had invented this five-line stanza in an effort to reproduce the rhythms of Horace. Its atmosphere is wholly Horatian. These verses, written to further the suit of a friend for some fair lady's hand or favor, deal with the most hackneyed classical and mythological conventions, - the power

\section{A N D MONOGRAPH S}




\begin{tabular}{|l|l|}
\hline GARCILASO DE LA VEGA \\
\hline $\begin{array}{l}\text { Of Orpheus, the lover's neglect of his } \\
\text { wonted sports, and the fate of Anaxarate. } \\
\text { But with what finesse he has woven them } \\
\text { into a fabric of delight! There is little or } \\
\text { nothing to stir the intellect or the imagina- } \\
\text { tion; like the Odes of Horace the poem } \\
\text { appeals directly to the senses in the suavity } \\
\text { and harmony of its cadences, the variety of } \\
\text { its diction and the quiet sense of mastery. } \\
\text { This group of poems in the impersonal } \\
\text { style is followed by a series of sonnets which } \\
\text { centre about the second phase of the poet's } \\
\text { amorous experience, a new passion for } \\
\text { some Neapolitan lady. For the most part } \\
\text { the sonnets of this group mark a return to } \\
\text { the Petrarchan style, or what the sixteenth } \\
\text { century conceived to be the Petrarchan } \\
\text { style. The first evidence of the new flame } \\
\text { comes in a sonnet (VII) built on a remin- } \\
\text { iscence of the Horatian lines: }\end{array}$ \\
$\begin{array}{l}\text { Motiva paries indicat uvida } \\
\text { suspendisse potenti } \\
\text { vestimenta maris deo, }\end{array}$ \\
\hline P A N I C N O T E S
\end{tabular}




\section{LIFE A N D WORKS}

which testifies to his inability to evade the new danger,

Mas del que viene no podre valerme.

$\mathrm{Y}$ en esto no voy contra el juramento, que ni es como los otros, ni en mi mano.

(lines 14-16)

The imperious sway of his desire is emphasized in another sonnet (XII) and finally he confesses his submission in the sonnet addressed to Boscán,

Sabed que en mi perfeta edad y armado, con mis ojos abiertos, me he rendido al niño que sabeys, ciego y desnudo.

(Son. XXVIII, 9-12)

From the first this episode in his life seems to have brought him little joy, and finally jealousy came to torment him. (XXX and $\mathrm{XXXI)}$. Among the compositions in this group are two sonnets (XVII and XVIII) which are more markedly Petrarchan than any of his earlier work, the first of the two containing in its second quatrain and first tercet an actual translation of the Italian original. Two others (XIV and XXVII)

\section{A N D MONOGRAP H S}




\begin{tabular}{|c|c|}
\hline 210 & GARCILASO DE LA VEGA \\
\hline & $\begin{array}{l}\text { apparently show reminiscences of the } \\
\text { Catalan poet, Ausias March. It is pos- } \\
\text { sible, however, that the simile of Sonnet } \\
\text { XIV which is derived from March may } \\
\text { have come through an imitation of Boscán, } \\
\text { who borrowed the figure in one of his son- } \\
\text { nets (LXXII, I 2-I 4). The second of these } \\
\text { sonnets (XXVII) has been the theme of } \\
\text { considerable discussion, since it is the only } \\
\text { sonnet showing oxytone rhymes, and also } \\
\text { because in many manuscripts another ver- } \\
\text { sion, with paroxytone rhymes, is attrib- } \\
\text { uted to Diego de Mendoza. } \\
\text { M. Morel-Fatio has expressed the belief } \\
\text { that the rhymes are a proof that the sonnet } \\
\text { is not the work of Garcilaso, but that of } \\
\text { Boscán or Mendoza. Menéndez y Pelayo, } \\
\text { however, pointed out }{ }^{2} \text { that this argument } \\
\text { is invalidated by Garcilaso's use of oxytone } \\
\text { rhymes in Canción II, further remarking } \\
\text { that the fact that the rhymes of the } \\
\text { Catalan original are oxytone might well } \\
\text { have influenced their use in the imitation. } \\
\text { A more serious doubt on the authenticity } \\
\text { of the sonnet is cast by the uncertainty as }\end{array}$ \\
\hline & H I P A N IC NOTES \\
\hline
\end{tabular}




\section{LIFE A N D WORKS}

to whether Garcilaso was personally familiar with the work of the great Catalan imitator of Petrarch. The only other reminiscence in his writings, as we have just remarked, may quite as well have come from Boscán. The latter's familiarity with the poetry of his fellow-countryman is revealed in numerous imitations; Diego de Mendoza, too, frequently turns to March for his images; in fact, the simile of Love's garment, which is the theme of the disputed sonnet, occurs in his first Eclogue. ${ }^{1}$

On the other hand, the inclusion of this sonnet among the compositions which Boscán had gathered, if not prepared, for the press would seem to warrant a belief in its authenticity. And this belief is further borne out by the appearance of another version of the sonnet with paroxytone rhymes, slightly different from the version ascribed to Mendoza, in a manuscript used by El Brocense in the preparation of his edition of the works of Garcilaso. It is perhaps impossible to give

\section{A N D MONOGRAPH S}




\begin{tabular}{|c|c|}
\hline 212 & GARCILASO DE LA VEGA \\
\hline & $\begin{array}{l}\text { any final answer to the question, but one } \\
\text { thing at least is certain: all of these three } \\
\text { versions are mutually dependent and in } \\
\text { no sense different translations from a com- } \\
\text { mon Catalan original, for the simile of } \\
\text { Ausias March occupies four lines in one } \\
\text { of his cants } \text {; }^{1} \text { from there it was expanded } \\
\text { into a sonnet by some Castilian author, at } \\
\text { first, no doubt, with oxytone rhymes, and } \\
\text { later "corrected," as the reviser believed, } \\
\text { with the paroxytone rhymes which had } \\
\text { become de rigueur. } \\
\text { The expedition to Tunis in r } 535 \text { in which } \\
\text { Garcilaso took part heightened his unhap- } \\
\text { piness in his new amours. From La Goleta } \\
\text { he wrote once more to Boscán, telling him } \\
\text { of his restlessness (Son. XXXII), and in } \\
\text { his Elegy II, also addressed to his friend, } \\
\text { he laments at the effects which his long } \\
\text { absence is sure to have, expressing his } \\
\text { fears in a tercet which rings with a sincerity } \\
\text { rare in his later work: } \\
\text { Alli mi coracon tuvo su nido } \\
\text { un tiempo ya, mas no se itriste! agora } \\
\text { o si estara ocupado o desparzido. } \\
\text { (lines } 40-42 \text { ) }\end{array}$ \\
\hline & H I SPANIC NOTES \\
\hline
\end{tabular}




\section{LIFE AND WORKS}

The pangs of absence inspire too his sonnet on the deserted hound (XXXVII). The last scene in this brief drama is depicted in Sonnet XXXIV: his triumphant emancipation from the yoke of Love:

Gracias al cielo doy que ya del cuello del todo el grave yugo he desasido.

(lines 1-2)

It is idle to speculate who among the fair ladies of the Neapolitan court the object of this love may have been. His own answer is final:

si preguntado

soy lo demas, en lo demas soy mudo.

(Son. XXVIII, 13-14.)

As a whole the sonnets of this group are not of high merit, - conventional exercises in the spinning of conceits which degenerate at times, as in Sonnet XXXI, into an allegorization of the very conceits. Lacking as they do, the warmth of sincerity which redeemed his first essays, and the polished elegance of his purely conventional classical reminiscences, they add

\section{A N D MONOGRAPHS}




\begin{tabular}{|c|c|}
\hline 214 & GARCILASO DE LA VEGA \\
\hline & $\begin{array}{l}\text { little to his literary credit. If his suit } \\
\text { depended upon them, it is not surprising } \\
\text { that it was unavailing or that some petty } \\
\text { rhymster of the Neapolitan school carried } \\
\text { off the lady, together with the poet's palm. } \\
\text { There remain a number of occasional } \\
\text { sonnets, written to his friends to celebrate } \\
\text { some personal experience or to sing some } \\
\text { special hymn of praise. Such are the } \\
\text { rather pompous epitaph written for the } \\
\text { tomb of his brother, Fernando de Guzmán, } \\
\text { who had died during the siege of Naples } \\
\text { (XVI); the sonnet to Julio, perhaps Giu- } \\
\text { lio Cesare Caracciolo, on the occasion of } \\
\text { a departure from Naples (XIX); and the } \\
\text { account of his being wounded in Africa, } \\
\text { addressed to Mario Galeota (XXXV). Two } \\
\text { of these sonnets are purely eulogistic (XXI } \\
\text { and XXIV), directed to his friend. and } \\
\text { patron, Don Pedro de Toledo, and to Dona } \\
\text { María de la Padula, to whom so many of } \\
\text { his Italian contemporaries paid tribute. } \\
\text { One sonnet in particular is interesting, as } \\
\text { showing a slight tendency to sarcastic rail- } \\
\text { lery. (XXII). The poet goes to visit a }\end{array}$ \\
\hline & H I P A N I C NOTES \\
\hline
\end{tabular}




\section{LIFE A N D W ORK S}

lady, who discovers his eyes resting with undue insistency upon her bosom, and who, hastening to remedy the neglect which made possible his offence, scratches herself with her breast-pin. Whereupon the poet observes, quoting for the only time in his works a line of Petrarch in the original:

non esservi passato oltra la gonna.

The whole scene offers a striking similarity with that portrayed in the anecdote of Luis Zapata, in which Garcilaso is represented as making a similar quick retort with a verse from from Petrarch's Trionfi. ${ }^{1}$

These fugitive works rank well with the other works of their type written by his contemporaries. Some of them possess that quiet geniality which marks his mythological verses; others even have a faint trace of personality. But their chief value today is the evidence they offer of some of the poet's friendships and intimacies and the slight information they afford of actual events in his life.

Certain other works are found attributed to Garcilaso either by the manuscripts in

\section{A N D MONOGRAPHS}




\begin{tabular}{|l|l|}
\hline 216 & $\begin{array}{l}\text { GARCILASO DE LA VEGA } \\
\text { which they appear or by their editors. The } \\
\text { first of these are the two sonnets in the } \\
\text { Cancionero Gayangos, first mentioned as } \\
\text { the work of Garcilaso by Knapp' and pub- } \\
\text { lished as his by Vollmöller. }{ }^{2} \text { Neither of } \\
\text { the sonnets bears the author's name in the } \\
\text { manuscript and the attribution to Gar- } \\
\text { cilaso was made solely because they occur } \\
\text { between authentic compositions of the } \\
\text { Toledan poet. Metrical reasons, however, } \\
\text { make it most improbable that they are his } \\
\text { work. The first of the sonnets "'iO celos de } \\
\text { amor, terrible freno!") has eight lines } \\
\text { which contain ten or twelve syllables and } \\
\text { there are two faulty rhymes; the second } \\
\text { ("El mal en mi ha hecho su çimiento.") } \\
\text { has six lines of ten or twelve syllables, } \\
\text { three faulty rhymes, and moreover, two } \\
\text { oxytone rhymes in the tercets. It is in- } \\
\text { credible that Garcilaso, even in his first } \\
\text { experiments, should have showed such a } \\
\text { consistent ignorance of the form and } \\
\text { movement of the sonnet. Added to this } \\
\text { is a more convincing argument. The first } \\
\text { of these sonnets is a word for word trans- }\end{array}$ \\
\hline H I S P A N I C N O T E S \\
\hline
\end{tabular}




\section{I F E A D W O R K}

lation of a sonnet of Sannazaro, "O gelosia, d'amanti or ribil freno." (No. XXIII) ${ }^{1}$. Now there is no evidence that Garcilaso knew the works of Sannazaro before his establishment in Naples in I 532; at least, not until then do we find any reminiscences of the Italian master in his verses. That he could have written this translation at a time when he was composing such finished hendecasyllables as those of Sonnet XI, for example, is beyond the realm of possibility.

Two other sonnets appear in a manuscript of the Biblioteca del Palacio in Madrid, under the name of Garcilaso de la Vega and have been published by $\mathrm{Sr}$. D. Ramón Menéndez Pidal. ${ }^{2}$ The manuscript is largely composed of works written between I 550 and I554 and there can be little doubt that the Garcilaso who is the author is the poet's son of the same name. It is of interest to note that the first of these sonnets treats of a theme already found among the coplas of our poet, the death of Dido. ${ }^{3}$

\section{A N D M O N O R A P H S}




\begin{tabular}{|c|c|}
\hline 218 & GARCILASO DE LA VEGA \\
\hline & $\begin{array}{l}\text { The thirty-eight sonnets and the five } \\
\text { canciones remain, then, the total of Gar- } \\
\text { cilaso's Canzoniere. Were they his only } \\
\text { compositions we should be indebted to } \\
\text { him for sharing in the creation of the } \\
\text { sonnet and cancion in Castilian and for } \\
\text { perfecting the former into a consummate } \\
\text { work of artistic expression. We should } \\
\text { also owe to his single example the trans- } \\
\text { planting of the ode form of the elder Tasso } \\
\text { into Spanish verse, where it has enjoyed } \\
\text { a continued popularity, which it never at- } \\
\text { tained in Italian, and became the medium } \\
\text { for some of Luis de León's noblest poems. } \\
\text { Apart from his distinction as an innovator, } \\
\text { in the shorter lyric forms Garcilaso is not } \\
\text { preeminently great, in fact is inferior to } \\
\text { many of his Italian contemporaries whose } \\
\text { work is now wellnigh forgotten. But oc- } \\
\text { casionally even here he attains that per- } \\
\text { fection of form which is an earnest of the } \\
\text { power which was destined to find fuller } \\
\text { expansion in his longer poems. }\end{array}$ \\
\hline & H I P A N IC NOTES. \\
\hline
\end{tabular}




\section{I F E A D WORKS}

\section{THE ELEGIES}

The two Elegies of Garcilaso were written in the same period, immediately after his return from the campaign in Tunis in the summer of $\mathrm{I} 535$. The first, "Al duque de Alva en la muerte de D. Bernaldino de Toledo, su hermano,' is properly an elegy in the classic sense of the word, a funereal poem. Since it offers the most noteworthy example of Garcilaso's methods of direct and indirect imitation, it deserves a detailed examination. In writing this lament to his patron and friend, the Duke of Alba, the poet used as his principal model a Latin poem by Girolamo Fracastoro, dedicated to Gianbattista Turriano of Verona to commemorate the death of his brother, Marcantonio Turriano. But in addition to this work, he had in mind two other poems written under similar circumstances, the first the anonymous Latin elegy, "Ad Liviam Augustam, de morte Drusi Neronis

\section{A N D MONOGRAPHS}




\begin{tabular}{|c|c|}
\hline 220 & GARCILASO DE LA VEGA \\
\hline & $\begin{array}{l}\text { filii eius," which was printed in the I } 47 \text { I } \\
\text { edition of Ovid's works, and which, attrib- } \\
\text { uted to C. Pedo Albinovanus, was long } \\
\text { reprinted among the works of the Latin } \\
\text { elegaic poet; the second, an elegia of Ber- } \\
\text { nardo Tasso, dedicated to Bernardino Rota } \\
\text { on the death of his brother and published } \\
\text { in the second edition of his Amori in I } 534 \text {. } \\
\text { While these three works are responsible for } \\
\text { the general plan and for most of the details } \\
\text { of Garcilaso's poem, in the few brief pas- } \\
\text { sages which he interpolated we find other } \\
\text { reminiscences of his reading, images and } \\
\text { phrases which recall Virgil, Horace, Pe- } \\
\text { trarch and Ariosto. } \\
\text { The first part of the Elegy follows } \\
\text { Fracastoro very closely, at times translat- } \\
\text { ing the original, at times offering a freer } \\
\text { paraphrase. } \\
\text { Etsi egomet tanti casu perculsus amici } \\
\text { solamen nostris discuperem lacrimis, } \\
\text { ne mea perpetuo manarent lumina fletu } \\
\text { pergeret aut tantus urere corda dolor, } \\
\text { attamen, ut mi animi valuit concedere, } \\
\text { amaror, }\end{array}$ \\
\hline & HISPANIC NOTES \\
\hline
\end{tabular}




\section{LIFE A N D WORKS}

221

istaec moesta tibi carmina persolvi, quo fortasse meis consolarere Camoenis, si miseros quidquam Musa levare potest, (lines 1-8)

begins Fracastoro, and Garcilaso's version is:

Aunque este grave caso aya tocado con tanto sentimiento el alma mia que de consuelo estoy necessitado,

con que de su dolor mi fantasia se descargasse un poco y se acabasse de mi contino llanto la porfia, quise, pero, provar si me bastasse el ingenio a escrivirle algun consuelo, estando qual estoy, que aprovechasse, para que tu reziente desconsuelo la furia mitigasse, si las musas pueden un coraçon alçar del suelo.

(lines 1-12)

The following lines of the original are treated in freer fashion, with a change of order:

Ac ne tu lacrimas paullatim totus abires liquitur ut pluvio tacta pruina Noto, quandoquidem cari fato te fratris acerbo est rumor in extrema vivere tristitia,

\section{A N D MONOGRAPH S}




\begin{tabular}{|c|c|}
\hline 222 & GARCILASO DE LA VEGA \\
\hline & $\begin{array}{l}\text { nec iam posse quietis habere, aut commoda } \\
\text { somni, } \\
\text { sed cedente die, sed redeunte queri, } \\
\text { (lines 9-14) } \\
\text { becomes: } \\
\text { Y poner fin a las querellas que usas, } \\
\text { con que de Pindo ya las moradoras } \\
\text { se muestran lastimadas y confusas; } \\
\text { que, segun he sabido, ni a las oras } \\
\text { que el sol muestra, ni en el mar se asconde, } \\
\text { de tu lloroso estado no mejoras; } \\
\text { antes, en el permaneciendo, donde } \\
\text { quiera que estas, tus ojos siempre bañas } \\
\text { y el llanto a tu dolor assi responde, } \\
\text { que temo ver desechas tus entrañas } \\
\text { en lagrimas, como al lluvioso viento } \\
\text { se derrite la nieve en las montañas. } \\
\text { (lines 13-24). } \\
\text { The thought of the line thirteen of the } \\
\text { original is expanded in the four follow- } \\
\text { ing tercets: } \\
\text { Si acaso el trabajado pensamiento } \\
\text { en el comun reposo se adormece, } \\
\text { por tornar al dolor con nuevo aliento, } \\
\text { en aquel breve sueño te aparece }\end{array}$ \\
\hline & H I P A N I C NOTES \\
\hline
\end{tabular}




\section{LIFE A N D W ORK S}

la imagen amarilla del hermano que de la dulce vida desfallece;

y tu, tendiendo la piadosa mano, provando a levantar el cuerpo amado. levantas solamente el ayre vano;

y del dolor el sueño desterrado, con ansia vas buscando el que partido era ya con el sueño y alongado;

(lines 25-36)

by the inclusion of an idea derived from the Elegy Ad Liviam: ${ }^{1}$

Et modo per somnos agitaris imagine falsi, teque tuo Drusum credis habere sinu?

Et subito tentasque manu, sperasque receptum;

quaeris et in vacui parte priore tori ?

(lines 325-8)

The long comparison of Lampetie's grief, developed in the following tercets (lines $37-57$ ), is based closely on Fracastoro (lines 15-24), with an interesting evasion of the formal "septem noctes, septem dies," (lines I9-20) by the vaguer, more modern phrase, "O quantas vezes . . . Y quantas otras . . " (lines 5I-55). The picture of the

\section{A N D MONOGRAPHS}




\begin{tabular}{|c|c|}
\hline 224 & GARCILASO DE LA VEGA \\
\hline & $\begin{array}{l}\text { intimacy which existed between the two } \\
\text { brothers (lines } 58-75 \text { ) is much more loosely } \\
\text { connected with the Latin; there is even a } \\
\text { Petrarchan simile introduced, } \\
\text { como en luziente de cristal coluna, } \\
\text { que no encubre de quanto se avezina } \\
\text { a su biva pureza, cosa alguna, (lines 73-75), } \\
\text { recalling the image: } \\
\text { dinanzi una colonna } \\
\text { cristallina, et iv'entro ogni pensero } \\
\text { scritto, e fôr tralucea sí chiaramente } \\
\text { che mi fêa lieto e sospirar sovente. } \\
\text { (Canz. XXV, 27-30) } \\
\text { The lament at the emptiness of worldly } \\
\text { success in the succeeding tercets (lines } \\
76 \text {-9o) is translated from Fracastoro. At } \\
\text { this point, the latter had introduced a } \\
\text { reference to the death of another friend, } \\
\text { Cotta; Garcilaso has replaced it with two } \\
\text { tercets, displaying keenly his own bitter- } \\
\text { ness at his life: } \\
\text { ¿Que se saca de aquesto? \&Alguna gloria? } \\
\text { \&Algunos premios o agradecimiento? } \\
\text { Sabralo quien leyere nuestra bistoria. }\end{array}$ \\
\hline & H I P A N I N NTES \\
\hline
\end{tabular}




\section{LIFE A N D W O R K}

Verase alli, que como polvo al viento, assi se deshara nuestra fatiga, ante quien se endereça nuestro intento.

(lines 91-96).

From this point on, Garcilaso departs from the close imitation of Fracastoro, although the general lines are still followed. After a brief passage picturing the futility of human hopes and the beauty which Don Bernaldino revealed even in death, he turns his sympathies to the mother and sisters of the dead youth. It is probable that the thought was suggested by the portrayal of Livia's grief in the elegy dedicated to her, and the references there to the other members of the family of Drusus, but his description of the frenzy of their grief in the lines.

a todas las contemplo desparziendo de su cabello luengo el fino oro, al qual ultraje $\mathrm{y}$ daño estan haziendo, (lines 139-41)

is apparently a reminiscence of Ariosto, percosse il seno e si stracciò la stola, e fece all'aureo crin danno e dispetto.

(Orlando furioso, V, 60, 3-4)

\section{A N D MONOGRAPH S}




\begin{tabular}{|c|c|}
\hline 226 & GARCILASO DE LA VEGA \\
\hline & $\begin{array}{l}\text { The introduction of the river-god and } \\
\text { his nymphs (lines I } 42-80 \text { ) goes back to } \\
\text { the elegy Ad Liviam, from which Fracas- } \\
\text { toro's use of the same device probably de- } \\
\text { pends. Garcilaso has, however, added cer- } \\
\text { tain details: Tormes issues from his stream } \\
\text { to lie upon the sands; the nymphs are } \\
\text { charged with the special function of con- } \\
\text { soling the mother, and presently a wanton } \\
\text { rout of satyrs, fauns and nymphs are intro- } \\
\text { duced to divert the troubled spirit of Don } \\
\text { Fernando. Turning now to the latter, the } \\
\text { poet heartens him with an appeal to his } \\
\text { distinguished position in life and his obli- } \\
\text { gation to deport himself with Stoic in- } \\
\text { difference in the presence of misfortune. } \\
\text { The argument which he employs to dis- } \\
\text { courage further lamentation, namely: that } \\
\text { the great heroes and heroines of mythology } \\
\text { eventually dried their tears, is curiously } \\
\text { derived. } \\
\text { The elegy Ad Liviam had cited the ex- } \\
\text { ample of Priam's grief at the death of } \\
\text { Hector; Fracastoro had begun his list of } \\
\text { examples with that of Orpheus. Garci- } \\
\text { laso uses the comparison with Priam, }\end{array}$ \\
\hline & H I SPANIC NOTES \\
\hline
\end{tabular}




\section{I F E A N D W O R K S}

No fue el troyano principe llorado siempre del viejo padre dolorido, ni siempre de la madre lamentado;

antes, despues del cuerpo redimido con lagrimas humildes y con oro, que fue del fiero Achilles concedido,

y reprimiendo el lamentable choro del frigio llanto, dieron fin al vano $\mathrm{y}$ sin provecho sentimiento y lloro, (lines 214-222)

but in language which plainly recalls the Horatian stanza,

At non ter aevo functus amabilem ploravit omnes Antilochum senex annos, nec inpubem parentes

Troilon aut Phrygiae sorores

flevere semper. (Odes, I, IX, 13-18)

His second example, of the grief which Venus overcame, is translated from the elegy of Bernardo Tasso, ${ }^{1}$ of which it preserves the gracefulness and charm.

Having demonstrated the folly of excessive grief, the poet turns to the thought of the immortality of the departed, picking up in passing (lines 253-55) a reference to Hercules on Mount (leta, derived from a line (257) in the elegy Ad Liviam. The

\section{A N D MONOGRAPHS}




\begin{tabular}{|c|c|}
\hline 228 & GARCILASO DE LA VEGA \\
\hline & $\begin{array}{l}\text { meeting with the father and grandfather, } \\
\text { although suggested by Fracastoro, }{ }^{1} \text { is made } \\
\text { a specific reference to Don García and Don } \\
\text { Fadrique de Toledo. His picture of the } \\
\text { realm of the blessed is distinctly pagan; } \\
\text { its closing lines strongly suggest Cicero's } \\
\text { description in the Somnium Scipionis, "Tam } \\
\text { ipsa terra ita mihi parva visa est, ut me } \\
\text { imperii nostri, quo quasi eius attingimus, } \\
\text { paeniteret." } 2 \text { But in spite of this classic } \\
\text { atmosphere, there are tercets which recall } \\
\text { rather the Christian conception of Para- } \\
\text { dise, with its stream of Divine Grace, } \\
\text { kindling the souls of the blessed, } \\
\text { E vidi lume in forma di riviera, } \\
\text { fulvido di fulgore, intra due rive, } \\
\text { dipinte di mirabil primavera, } \\
\text { (Parad. XXX, 61-63) } \\
\text { such as: } \\
\text { iO bienaventurado! que sin ira, } \\
\text { sin odio, en paz estas, sin amor ciego, } \\
\text { con quien aca se muere y se sospira; } \\
\text { y en eterna holgança y en sossiego } \\
\text { bives y biviras, quanto encendiere } \\
\text { las almas del divino amor el fuego. } \\
\text { (lines 289-94) }\end{array}$ \\
\hline & H I S A N I C NOTES \\
\hline
\end{tabular}




\section{I F E A N D W O R K S}

The closing tercets assume the conventional forms, but the promise of the poet to do his part in singing eternal praise is addressed, strangely enough, not to the departed, but to Don Fernando,

Yo te prometo, amigo, que entre tanto que el sol al mundo alumbre y que la escura noche cubra la tierra con su manto,

$\mathrm{y}$ en tanto que los peces la hondura humida habitaran del mar profundo, $\mathrm{y}$ las fieras del monte la espessura.

se cantara de ti por todo el mundo, que en quanto se discurre, nunca visto de tus años jamas otro segundo sera, desdel Antartico a Calisto.

(lines 298-307)

The phraseology of the passage is frankly Virgilian,

Dum iuga montis aper, fluvios dum piscis amabit,

dumque thymo pascentur apes, dum rore cicadae,

semper honos nomenque tuum laudesque manebunt.

(Egl. V, 76-78)

\section{A N D MONOGR A P H S}




\begin{tabular}{|c|c|}
\hline 230 & GARCILASO DE LA VEGA \\
\hline & $\begin{array}{l}\text { and the last line is from Ariosto, } \\
\text { tra quanto èn mezzo Antartico e Calisto. } \\
\text { (Orlando furioso, III, 17, 6) } \\
\text { It is important to recognize that such a } \\
\text { process of literary construction, which we } \\
\text { should to-day regard as mere pilfering, far } \\
\text { from being questioned in Garcilaso's gener- } \\
\text { ation, was regarded as the canon of art. } \\
\text { Imitation, to the man of letters of the } \\
\text { Renaissance, was the supreme test of } \\
\text { genius; creative power was looked upon } \\
\text { with suspicion. And it must also be re- } \\
\text { membered that the methods of education } \\
\text { of the time, with the large stress placed } \\
\text { upon the memorization of the classic } \\
\text { masters, Virgil, Ovid, and Horace, and no } \\
\text { doubt continued in the study of Petrarch, } \\
\text { equipped the poets with an unusual famil- } \\
\text { iarity with the master works of the past. } \\
\text { Their minds were vast storehouses of } \\
\text { mythological information and classical } \\
\text { phraseology. Had they striven to record } \\
\text { their personal impressions of life or to } \\
\text { leave an image of their own emotions, they }\end{array}$ \\
\hline & H I SPANIC NOTES \\
\hline
\end{tabular}




\section{LIFE A N D WORK S}

could not have failed to reflect the diction with which their minds were filled. The more then, when their effort was to reproduce in different form materials already employed, must we expect them to show their reading and study. At their worst. they produced but the dry dust of literature; at their best they created forms of the highest technical mastery and even of enchanting atmosphere, like the Arcadia of Sannazaro.

With such an inspiration, it is not surprising that the poem of Garcilaso is, as a whole, cold and unfeeling; it smacks of the formal written exercise. Occasionally, when the sentiments which he finds in his models awaken a sincere echo in his own heart, as in the passage in which he refers to the hardships of military service and the emptiness of its rewards, there is a momentary ring of emotion. But the rest awakens little sympathy, gives little consolation. In this respect, although equal to the works of Fracastoro or the elder Tasso, it is far inferior to the elegy $A d$

\section{A N D MONOGRAPH S}




\begin{tabular}{|c|c|}
\hline 232 & GARCILASO DE LA VEGA \\
\hline & $\begin{array}{l}\text { Liviam. In workmanship it deserves higher } \\
\text { praise; the verse is fluent, at times melo- } \\
\text { dious; the structure of the poem is well } \\
\text { balanced. In spite of its funereal character, } \\
\text { the author has ventured to relieve it by } \\
\text { the use of lively, even sensuous images, } \\
\text { giving it a variety, which, though of ques- } \\
\text { tionable taste, as Herrera remarked," add } \\
\text { greatly to its artistic effectiveness. } \\
\text { If the first Elegy represents the extreme } \\
\text { example of Garcilaso's imitation of foreign } \\
\text { models, the second may be considered as } \\
\text { the best evidence of his power of original } \\
\text { composition. In fact, none of his works is } \\
\text { so rich in its revelation of his personality, } \\
\text { none approaches so closely our modern } \\
\text { conception of poetic individuality. It was } \\
\text { undoubtedly written before the first Elegy, } \\
\text { probably, as the poet states in the opening } \\
\text { tercet, at Trapana in Sicily, on the way } \\
\text { from Tunis to Naples. Although the poem } \\
\text { is intitled an "elegy," it is in reality an } \\
\text { "epístola" or "capítulo" in tercets, ad- } \\
\text { dressed to his friend Boscár. }\end{array}$ \\
\hline & H I S P A I C NOTES \\
\hline
\end{tabular}




\section{I F E A N D W R K S}

The mention of the company in which the poet finds himself leads at once to a bitter criticism of their aims and methods. To Garcilaso, this throng of courtiers is composed wholly of men seeking personal advancement; some confess it openly; others wear a pretence of virtue in their service. This criticism of court life is peculiarly significant; Garcilaso had known its workings from the days when Charles $\mathrm{V}$ first arrived in Spain; it is perhaps the first condemnation of a system which eventually was to undermine the life of the country. As for himself, he boasts that he strives to follow the golden mean, but we know that his whole life was devoted to winning the evidence of favor, the futility of which he here so boldly proslaims.

The pungent criticism of his fellows seems to slip almost unconsciously from his pen; it is almost the only trace of satire in his work. And he hastens to apologize in a tercet which has been widely quoted, from Sá de Miranda to Lope de Vega,

\section{A N D M O N O G R P H S}




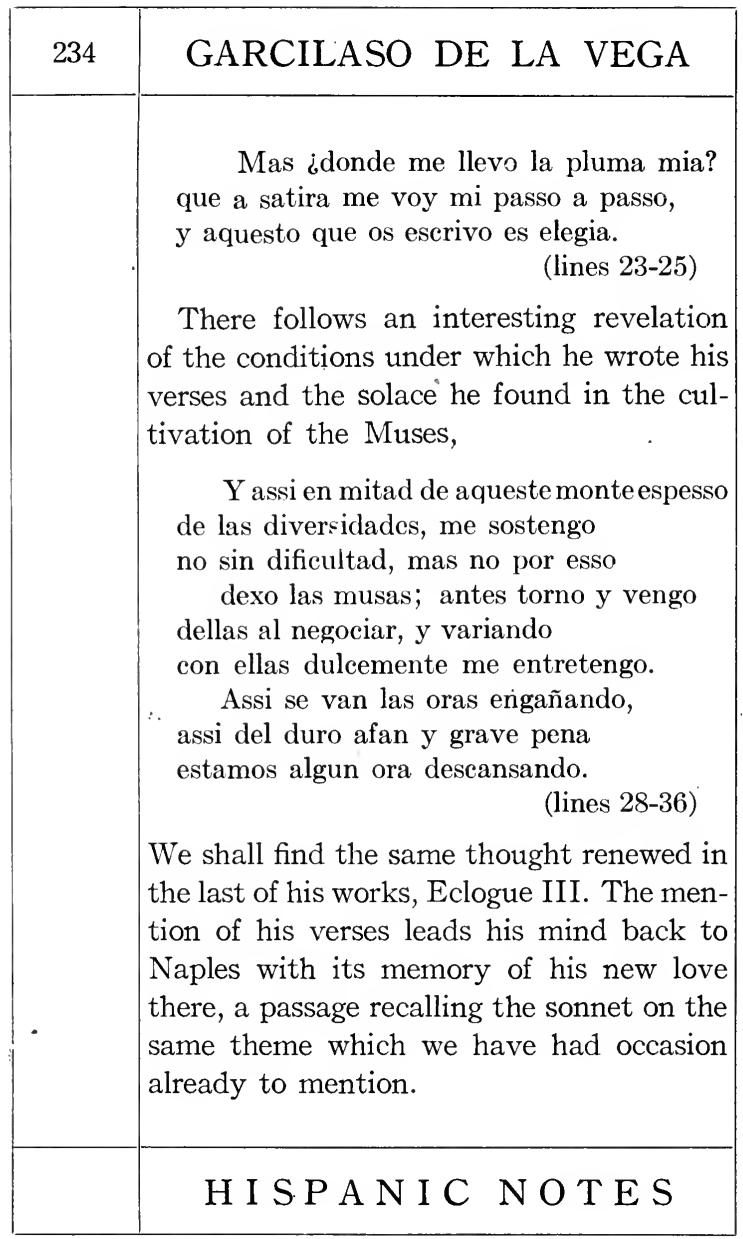




\section{LIFE AND WORKS}

235

The long comparison which follows, between the effect of absence on love and that of water on fire, seems to have been an image of his own, one of the few original fancies in his work. Though it ends with a somewhat overdrawn conclusion, it is a sound comparison, its expression is convincing. Once more the poet turns to the analysis of his own situation: his military life is out of keeping with the prosecution of his amorous suit; death is his only hope! With a strangely ironical comment, destined soon to be fulfilled in a fashion far more literal than he implied, he writes, appealing to the god of war:

Exercitando por mi mal tu officio, soy reduzido a terminos que muerte sera mi postrimero beneficio;

y esta no permitio mi dura suerte que me sobreviniesse peleando, de hierro traspassado agudo y fuerte.

(lines 100-105)

For a moment the contrast between his own situation and that of Boscán makes him turn to his friend, whom he pictures

\section{A N D MONOGRAPHS}




\begin{tabular}{|c|c|}
\hline 236 & GARCILASO DE LA VEGA \\
\hline & $\begin{array}{l}\text { in the quiet enjoyment of his leisure by the } \\
\text { sea, surrounded by his friends, celebrating } \\
\text { in his verses his faithful wife. But the } \\
\text { very contrast makes his own life seem more } \\
\text { wretched, } \\
\text { Y como conduzido mercenario } \\
\text { voy do fortuna a mi pesar me embia } \\
\text { sino a morir, que aqueste es voluntario. } \\
\text { (lines 157-59) } \\
\text { His whole life has been a vain pursuit of } \\
\text { his heart's desires. So unchanging is his } \\
\text { ill-fortune that wherever he turns his steps, } \\
\text { - and the image he uses is one of his } \\
\text { favorite classical figures, - fear and jeal- } \\
\text { ousy clutch his heart. As in so many of } \\
\text { his poems, the end of his hope is death. } \\
\text { Artistically the poem does not rank with } \\
\text { many of his works; it is plainly improvised; } \\
\text { there is a lack of logical coherence. But } \\
\text { in its freshness and originality, in its free- } \\
\text { dom from conceits and stilted expressions, } \\
\text { it remains as one of his most interesting } \\
\text { works. }\end{array}$ \\
\hline & H I P A N I N NTES \\
\hline
\end{tabular}




\section{LIFE A N D W ORKS}

3. THE EPISTLE to BoscáN.

The Epistle to Boscán, Garcilaso's only experiment in versos sueltos, is chiefly significant for its form, of which we shall speak in a later chapter. But it is also important because of its revelation of the closeness of the ties which bound him with his Catalan friend and the influence which this friendship had upon his own life. The ways were long in the sixteenth century and the solitary traveler found ample time for reflection. What was more natural, then, than that Garcilaso, as he fared upon his lonely journey back to Naples, should have thought long of the pleasant days which he had just spent with his friend in Barcelona? Perhaps he had heard of Aristotle's discussion of friendship in the Ethics and found his remarks borne out in his own experience. The greatest satisfaction which he derives from their friendship is the consciousness of affection which he feels in his own heart,

\section{A N D MONOGRAPHS}




\begin{tabular}{|c|c|}
\hline 238 & GARCILASO DE LA VEGA \\
\hline & $\begin{array}{l}\text { Ninguna cosa en mayor precio estimo } \\
\text { ni me haze gustar del dulce estado } \\
\text { tanto como el amor de parte mia. } \\
\text { (lines } 39-41 \text { ) }\end{array}$ \\
\hline & $\begin{array}{l}\text { The latter part of the poem assumes a } \\
\text { more confidential, personal tone. Once he } \\
\text { had found traveling in France a delight, } \\
\text { perhaps that was in I } 530 \text {. Now he regrets } \\
\text { his former praise. His woes are those of } \\
\text { the modern tourist: }\end{array}$ \\
\hline & $\begin{array}{l}\text { Vinos azedos, camareras feas, } \\
\text { varletes codiciosos, malas postas, } \\
\text { gran paga, poco argen, largo camino. } \\
\text { (lines 73-76) }\end{array}$ \\
\hline & $\begin{array}{l}\text { Then, as becomes a letter-writer, he send } \\
\text { greetings to a common friend, with a word } \\
\text { of banter at his stoutness, and signs his } \\
\text { place and date, Avignon, October I } 2,5^{1} 4^{1}\end{array}$ \\
\hline & $\begin{array}{l}\text { The poet himself disclaims any effort to } \\
\text { write in a lofty poetic style, }\end{array}$ \\
\hline & $\begin{array}{l}\text { Ni sera menester buscar estilo } \\
\text { presto, distincto, de ornamento puro, } \\
\text { tal qual a culta epistola conviene. } \\
\text { (lines } 5-7 \text { ) }\end{array}$ \\
\hline & F I S P N IC NOTES \\
\hline
\end{tabular}




\section{I F E A N D W O R K S}

In fact there is hardly a poetic image in the composition, unless it be the conventional periphrasis at the close. It is hard to see how the material gains by being presented in rhythm. For Garcilaso's blank verse is not a form of artistic expression. Although not inferior to Boscán's similar, and more lengthy experiment, it is wholly lacking the grace and variety which Juan de Jáuregui succeeded in imparting to the form in his exquisite translation of the Aminta. In Garcilaso's hands the strongly marked iambic cadence, more noticeable here than in his rhymed verses, becomes monotonous. It is an exercise, offering little ingenuity or variety.

\section{A N D M O N O G R P H S}




\begin{tabular}{|c|c|}
\hline 240 & GARCILASO DE LA VEGA \\
\hline \multirow[t]{2}{*}{$\cdot$} & $\begin{array}{l}\text { 4. THE ECLOGUEs. } \\
\text { To his Eclogues, more than to any of his } \\
\text { other works, Garcilaso owes his lasting } \\
\text { fame. For in that artificial form, so ap- } \\
\text { pealing to a highly conventionalized society, } \\
\text { he found a perfect medium for the expres- } \\
\text { sion of the characteristic qualities of his } \\
\text { genius: a certain atmosphere of melancholy } \\
\text { regret at the crudities and cruelties of life } \\
\text { and a splendid mastery of the forms of } \\
\text { harmony. } \\
\text { The first of the Eclogues was dedicated } \\
\text { to his patron, Don Pedro de Toledo, Vice- } \\
\text { roy of Naples. Written shortly after the } \\
\text { death of Isabel Freire, it is the outpouring } \\
\text { of the poet's grief at his double misfortune, } \\
\text { his beloved's marriage and her untimely } \\
\text { death. The plan is simple: after a brief } \\
\text { tribute to his patron, the poet introduces } \\
\text { two shepherds, Salicio and Nemoroso, who } \\
\text { sing their songs, one of jealous protest, the } \\
\text { other of bitter grief, and then withdraw } \\
\text { with their flocks. It is by no means new, }\end{array}$ \\
\hline & H I P A N I NOTES \\
\hline
\end{tabular}




\section{IFE A N D WORKS}

for it is precisely that followed by Virgil in his Ecloga YIII, and although the theme of the second shepherd's song is not Virgilian, even this contrast between the woes of the betrayed and the bereaved lovers is found in the Due pellegrini of Luigi Tansillo, which was probably produced as early as ${ }^{5} 528$ and which Garcilaso must have known.

Not only the main ciutline, but the minor details of the poem reveal a constant imitation of other pastoral poets. From the same eclogue of Virgil and from others of the same poet, particularly the second, Garcilaso has borrowed many of his phrases and figures, and his use of a refrain to close each stanza. The lament of Nemoroso is strongly reminiscent of the song of Ergasto in the fifth egloga of Sannazaro's Arcadia; his apostrophe to the lock of his lady's hair is translated from the words of Meliseo in the twelfth egloga of the same work. The other Italian poets, Petrarch, Tansillo. Ariosto and Bembo, seem to have suggested to him many of his poetic images.

\section{A N D MONOGRAPHS}




\begin{tabular}{|c|c|}
\hline 242 & GARCILASO DE LA VEGA \\
\hline & $\begin{array}{l}\text { Like the first of his Elegies, the poem is } \\
\text { a mosaic of reminiscences and of conscious } \\
\text { imitations. } \\
\text { What is it then, that gives the work its } \\
\text { charm? The answer is simple: the poem } \\
\text { is beautiful because it is the frank revela- } \\
\text { tion of the poet's own love and grief. The } \\
\text { form he uses is old and conventional; his } \\
\text { imagery is the stock material of the class- } \\
\text { ical Renaissance. But with the fire of his } \\
\text { heart he has fused this time-worn form } \\
\text { and matter into a gem of perfect beauty. } \\
\text { The emotion is genuine. These shepherds } \\
\text { are no puppets; their words glow with } \\
\text { sincerity. } \\
\text { In Garcilaso's own day there seems to } \\
\text { have been little doubt as to the identity of } \\
\text { these shepherds. "Salicio" was plainly an } \\
\text { anagram for the name Garcilaso; Sá de } \\
\text { Miranda, on the other hand, regularly re- } \\
\text { fers to the poet as "Nemoroso." It is } \\
\text { strange that no one has ever remarked } \\
\text { that the name "Nemoroso" is an adapta- } \\
\text { tion of the rest of the poet's name, "de la } \\
\text { Vega," for "vega" is regularly given as one }\end{array}$ \\
\hline & H I P A N I N NOTES \\
\hline
\end{tabular}




\section{LIFE A N D W ORKS}

of the translations for "nemus" in the Latin-Castilian dictionaries. The poet was plainly referring to himself in both cases; he assumed pastoral names derived from the different parts of his own name to cloak his different moods.

His commentators, however, would not have it so. "Salicio, es Garci-Lasso, $N e$ moroso, Boscan: porque nemus es el bosque," said Francisco Sánchez, ${ }^{1}$ and thereby diverted the attention of subsequent generations. His theory was elaborated by Luis Zapata, who declared in his Miscelánea $^{2}$ that Boscán was a suitor for the hand of Doña Isabel before her marriage. Herrera, perhaps to avoid following the opinion of Sánchez, informs us that Nemoroso represents the husband of Doña Isabel, Don Antonio de Fonseca! ${ }^{3}$ And between these two opinions the struggle has fluctuated.

It is needless to observe the impropriety of both these interpretations. Garcilaso's reference in Eclogue III to Nemoroso's

\section{A N D MONOGRAPHS}




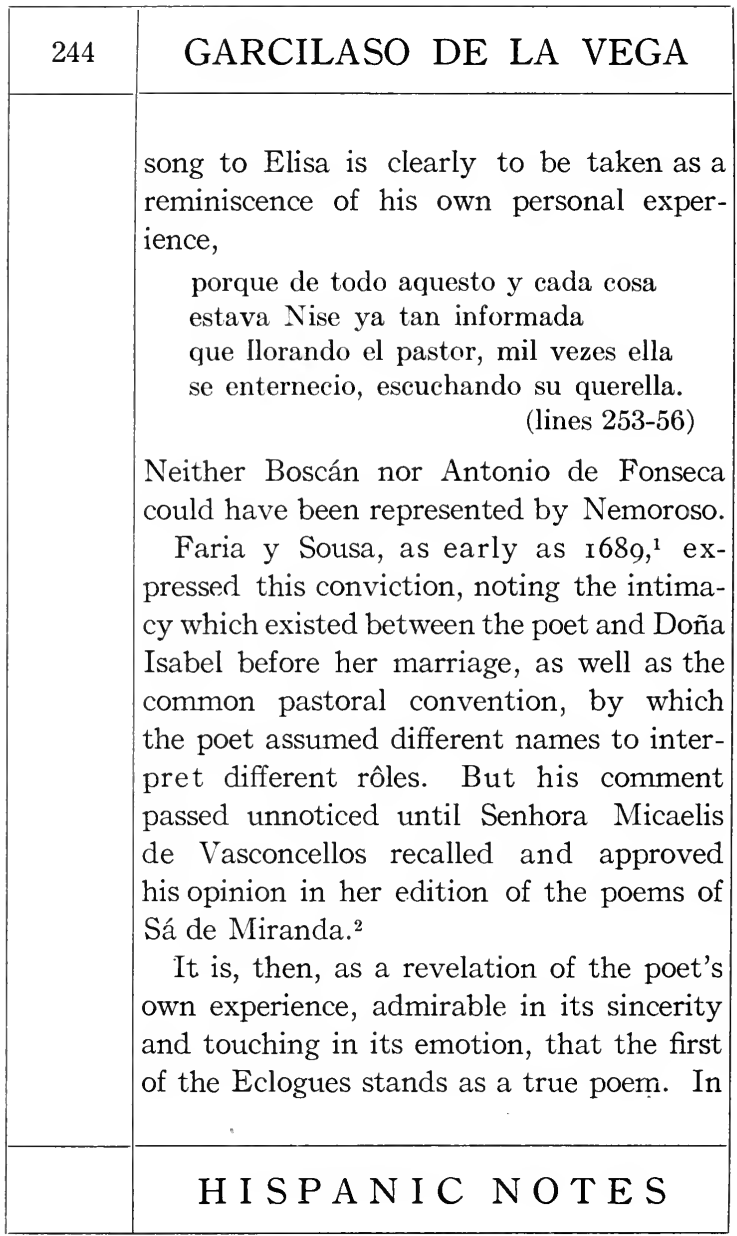




\section{LIFEAN D W O R K}

an age of artificial imitation it is eminent for its depth of real feeling and its wistful tenderness. Nowhere in the works of Garcilaso, rarely in the poems of the Renaissance, can we find a song which comes closer to our hearts than this cry of the poet's heart; disappointment and death have rarely received a more moving portrayal.

Not only in its emotion is it the most intense of his works, but in its form it shows his greatest perfection. The sturdy Castilian of the Middle Ages has become the medium for the most harmonious lyric expression, supple, replete with color, filled with musical cadences. In spite of an occasional lapse in technical formation, the difficult Petrarchan canzone has become a facile instrument, varied in its rhythm, capable of subtle tones; it is once for all established as a form for Spanish poetry. Such an achievement in itself would place Garcilaso among the epochmaking figures in Spanish literature; combined with its power of emotional appeal

\section{A N D MONOGR A P H S}




\begin{tabular}{|c|c|}
\hline 246 & GARCILASO DE LA VEGA \\
\hline & $\begin{array}{l}\text { it makes this little pastoral one of the out- } \\
\text { standing lyrics in Castilian poetry. If its } \\
\text { equal is to be found, it must. be sought } \\
\text { among the lyrics of Luis de León. } \\
\text { The longest and most pretentious of the } \\
\text { poems of Garcilaso is his second Eclogue, } \\
\text { written as a tribute to Fernán Álvarez } \\
\text { de Toledo, the Grand Duke of Alba, late } \\
\text { in r } 532 \text { or perhaps early in r } 533 \text {. Although } \\
\text { in many respects it is one of his least ar- } \\
\text { tistic works, it does offer us an example of } \\
\text { his more familiar speech and is therefore } \\
\text { linguistically of peculiar importance. More- } \\
\text { over it provides the only example of the } \\
\text { poet's use of the Italian rima al mezzo, the } \\
\text { one metrical innovation of Garcilaso which } \\
\text { was not destined to find a permanent place } \\
\text { in the Castilian Parnassus. Finally it adds } \\
\text { in some measure to our knowledge of cer- } \\
\text { tain events in the life of the poet. These } \\
\text { qualities atone for its tedious prolixity. } \\
\text { The poem opens with a soliloquy of the } \\
\text { shepherd Albanio (the Duke of Alba), la- } \\
\text { menting his misfortune in love. Turning }\end{array}$ \\
\hline & H I P A N I N N T E S \\
\hline
\end{tabular}




\section{I F E A D WORKS}

to sleep as his only consolation, he lies down and falls asleep. Two shepherds pass; one, Salicio, singing in perfect Horatian style the praises of the solitude of the country, free from the strifes and cares of court. Of a sudden, he spies the sleeping swain and in altered strains, reflects on the blessings of sleep for the weary spirit. Then he recognizes the shepherd as Albanio, of whose unhappy state he has heard. Half asleep still, the latter begins to stir, protesting that his dream has vanished. Salicio speaks to him and after a brief conversation persuades him to tell the story of his trouble. Since early childhood, Albanio has lived on terms of the closest intimacy with a cousin and their intimacy had ripened into love on his part. There is little difficulty in recognizing in this maiden, "de mi sangre y abuelos descendida," whom we shall presently meet as the shepherdess, Camila, the wife of the Duke of Alba, María Enríquez, daughter of the Conde de Alba de Liste, Diego En-

\section{A N D MONOGRAPH S}




\begin{tabular}{|c|c|}
\hline 248 & GARCILASO DE LA VEGA \\
\hline & $\begin{array}{l}\text { ríquez, and Doña Leonor de Toledo, and } \\
\text { granddaughter of Don Fadrique de Toledo, } \\
\text { second Duke of Alba. } \\
\text { The long story (lines I 7o-68o), which } \\
\text { Albanio relates of their youthful pastimes } \\
\text { and the unhappy progress of his love, is } \\
\text { translated from the eighth prosa of the } \\
\text { Arcadia. In general the translation is } \\
\text { close, as close as it is possible to write a } \\
\text { translation in verse. The only liberties } \\
\text { which Garcilaso takes with the original are } \\
\text { the introduction of a brief rest half way } \\
\text { through the tale (lines } 365-4 \text { I } 5 \text { ) in which } \\
\text { Albanio hesitates to continue until assured } \\
\text { of Salicio's sympathetic interest, and a } \\
\text { change in the final scene, in which the lover } \\
\text { is deterred from committing suicide, not } \\
\text { as in Sannazaro by the appearance of two } \\
\text { white doves in the oak tree above him, but } \\
\text { by a sudden gust of wind which throws } \\
\text { him flat upon his back. Artistically the } \\
\text { passage is fully the equal of the Italian } \\
\text { original, although the immediate applica- } \\
\text { tion to the experiences of the Duke of } \\
\text { Alba is far-fetched. Salicio's attempt to }\end{array}$ \\
\hline & H I SPANIC NOTES \\
\hline
\end{tabular}




\section{IFE A N D W ORKS}

encourage Albanio is brusquely repelled by the latter, who leaves his friend to ponder on the futility of any effort to save him until time shall have softened him. After this brief stanza of soliloquy, Salicio too departs to seek a nightingale's nest for Gravina, whose identity in real life remains a mystery.

Hardly have the two shepherds disappeared when a shepherdess, Camila; appears, following the trail of a stag that has been wounded by one of her arrows. Tempted by the coolness of the spot, she gives up the chase. The sight of the spring recalls to her mind the scene when she had learned of Albanio's passion for her. Reproaching him for his daring and swearing allegiance to Diana, she lies down beside the spring to sleep till the heat of the day is past. As she lies asleep, Albanio returns and after a struggle with himself, sits down by her side and takes her hand. Camila, awakened, is terrified and tries to free herself. But Albanio is obstinate and not

\section{A N D MONOGRAPHS}




\begin{tabular}{|l|l|}
\hline GARCILASO DE LA VEGA \\
\hline $\begin{array}{l}\text { until she pretends that she has lost her } \\
\text { golden brooch does he release his hold and } \\
\text { allow her to escape. } \\
\text { Discovering that he has been duped, the } \\
\text { poor shepherd is frenzied and begins to } \\
\text { rave. His ravings, it must be said, are a } \\
\text { parody of Ovid's description of Narcissus } \\
\text { beside the spring, for Albanio is convinced } \\
\text { that some one has stolen his body and now } \\
\text { he discovers it mocking him from the depths } \\
\text { of the spring. Salicio, who has returned ac- } \\
\text { companied by Nemoroso, is fearful lest } \\
\text { in his frenzy he will do harm to himself and } \\
\text { starts to hold him. Albanio turns on him } \\
\text { and without the interference of Nemoroso } \\
\text { it would have fared ill with Salicio. To- } \\
\text { gether they are able to master him and } \\
\text { having bound him fast, they leave him on } \\
\text { the ground to recover. } \\
\text { Salicio's question as to how Albanio can } \\
\text { be cured is answered by Nemoroso in a } \\
\text { long tribute to a certain Severo, who is } \\
\text { none other than the Dominican friar of } \\
\text { that name who was the tutor of the Duke } \\
\text { from r } 522 . \text { The magic powers attributed }\end{array}$ \\
\hline H I S P A N I C N O T E S \\
\hline the
\end{tabular}




\section{LIFE AND WORKS}

to him are purely conventional: those of Medea in Ovid or of the old witch in the ninth prosa of the Arcadia. What is more interesting is Nemoroso's confession that Severo has cured him of a mad love and convinced him of the error of his ways. After another pause, introduced like that in the narrative of Albanio to break the monotony, Nemoroso continues his story of Severo, who has received from the old rivergod, Tormes, a revelation of the lords of the Tormes, that is, of the House of Toledo. This revelation, inscribed upon a crystal urn, recalls the familiar device of pseudoprophecies found on shields; here plainly the urn is more fitting to the river-god. It contains at once a history of the family of the young Duke from the time of Fernán Alvarez de Toledo, Count of Alba in the reign of John II, and also a detailed account of the Duke's own career down to his return from the siege of Vienna in the spring of 1533 .

This long passage (lines II 8 I-I 743), written in rima al mezzo lines, is of scant

\section{A N D MONOGRAPHS}




\begin{tabular}{|c|c|}
\hline 252 & GARCILASO DE LA VEGA \\
\hline & $\begin{array}{l}\text { literary merit. Most of it, it is true, is } \\
\text { original, particularly those parts which } \\
\text { record actual events in the life of the Duke } \\
\text { or his ancestors. But Garcilaso was not } \\
\text { gifted as a narrative poet and the peculiar } \\
\text { verse, with its complicated inner rhyme, } \\
\text { accentuates the monotony of the account. } \\
\text { The story of Don Fernando's life is told } \\
\text { with more ornament, much of it derived } \\
\text { from the last canto of the Orlando furioso, } \\
\text { with an occasional classical reminiscence, } \\
\text { like that of the bridal scene from Catullus. } \\
\text { We learn of the Duke's education by Severo } \\
\text { and Boscán, of his maiden exploit in arms } \\
\text { (it was at Fuenterrabía in I } 523 \text { ), of his } \\
\text { first meeting and love for the lady who was } \\
\text { destined to become his wife, of the duel } \\
\text { he fought on the bridge at Burgos and of } \\
\text { his marriage to Doña María Enríquez. } \\
\text { There follows an account of his journey } \\
\text { to Ratisbonne with Garcilaso and the } \\
\text { various details of the campaign against } \\
\text { Solyman which we have discussed in an } \\
\text { earlier chapter. The story on the urn } \\
\text { ends with his reunion with his wife, for in }\end{array}$ \\
\hline & H I P A N I NOTES \\
\hline
\end{tabular}




\section{LIFE A N D WORK S}

spite of Severo's plea, old Tormes refuses to disclose the meaning of the brilliance which still remains unexplained upon the urn. Severo, astounded at what he has seen, has written it down as best he can and thus Nemoroso has learned the story. With a brief exchange of opinions as to the importance of appealing to Severo to cure their friend and a few conventional pastoral phrases, in which there appears for the second time a mention of another friend, one Gualafrón, who is probably to be identified as the Marquis of Villafranca, Don Pedro de Toledo, the two shepherds part and the Eclogue ends.

As a composition, the poem is extremely uneven. Some of its lyrical passages, such as the opening song of Salicio (lines $38-76$ ), are as finished as the best work of the poet; at other times the style drags hea vily, hardly rising above the level of prose. Perhaps the most interesting feature in the whole work is the purely popular conversational style used in the dialogue passages. There is here a fine savor of old Castilian with its

\section{A N D MONOGRAPHS}




\begin{tabular}{|c|c|}
\hline 254 & $\begin{array}{l}\text { GARCILASO DE LA VEGA } \\
\text { proverbial phrases and its blunt directness. } \\
\text { Even more, there is a touch of real humor } \\
\text { which we should seek in vain in the rest } \\
\text { of his work. The scene at the spring is a } \\
\text { brief paso, with a strong sense of dramatic } \\
\text { feeling, and an unusually clever command } \\
\text { of dialogue. One wonders whether Gar- } \\
\text { cilaso's early death did not deprive Spain } \\
\text { of a potentially dramatic poet as well as } \\
\text { of her first lyric poet. Did not Don } \\
\text { Quixote and Sancho Panza, close to the } \\
\text { end of their journeyings, come upon a } \\
\text { group of youths and maidens performing } \\
\text { a part of this Eclogue? } \\
\text { The last of the Eclogues of Garcilaso, un- } \\
\text { doubtedly also the last of his works, opens } \\
\text { with this dedication: } \\
\text { Aquella voluntad onesta y pura, } \\
\text { illustre y hermosissima Maria, } \\
\text { que en mi de celebrar tu hermosura, } \\
\text { tu ingenio y tu valor estar solia, . } \\
\text { a despecho y pesar de la ventura } \\
\text { que por otro camino me desvia, } \\
\text { esta y estara en mi tanto clavada } \\
\text { quanto del cuerpo el alma acompanada. }\end{array}$ \\
\hline H I S P A N I C N O T E S \\
\hline
\end{tabular}




\section{IFE A N D W O R K S}

The identity of this María has never been definitely established, though Herrera says, "Some think that it was addressed to the Duchess of Alba (María Enríquez), others, to Doña María de Cardona, Marchioness de la Padula (to whom the poet dedicated Sonnet XXXIV); but the truth is, according to the statement of Don Antonio Puertocarrero, that it is addressed to Dona María de la Cueva, Countess of Ureña. mother of Don Pedro Girón, first Duke of Osuna." In spite of this authority, it is probable that the María to whom the poet expresses his devotion is none of these.

Several reasons bear out this fact. In this opening stanza, the poet speaks of a recent change of fortune which separates him from her. That this is subsequent to his exile in Naples in 1532 is clear from the lines,

Mas la fortuna, de mi mal no harta, me aflige $y$ de un trabajo en otro lleva: ya de la patria, ya del bien me aparta, y a mi paciencia en mil maneras prueva, (lines 17-20)

\section{A N D MONOGRAPHS}




\begin{tabular}{|c|c|}
\hline 256 & GARCILASO DE LA VEGA \\
\hline & $\begin{array}{l}\text { as well as by the fact that he refers to his } \\
\text { own first Eclogue as already well known } \\
\text { (lines } 249-52 \text { ). In fact there is every reason } \\
\text { to believe that the separation refers to his } \\
\text { departure from Naples for the campaign } \\
\text { in La Provence in I } 536 \text {. The María to } \\
\text { whom he is paying tribute, then, must be } \\
\text { some lady who is in Naples. This condi- } \\
\text { tion would eliminate the possibility of the } \\
\text { María of the poem being either the Duchess } \\
\text { of Alba or the Marchioness of Ureña, for } \\
\text { they were at the time both in Spain. Fur- } \\
\text { thermore it is clear that the poet is under } \\
\text { real obligation to this María the spirit of } \\
\text { devotion which animates him is something } \\
\text { quite alien to the gallant badinage of his } \\
\text { tribute to the Marchioness de la Padula. } \\
\text { It must also be observed that the four } \\
\text { nymphs whom he introduces in the poem } \\
\text { are real people in pastoral disguise, for he } \\
\text { remarks that one of them, Nise, is well } \\
\text { fitted to tell the story of Elisa, since she } \\
\text { has so often heard it from Nemoroso; in } \\
\text { other words, Nise represents one of the } \\
\text { poet's intimate friends. Of further import }\end{array}$ \\
\hline & H I S A N I C NOTES \\
\hline
\end{tabular}




\section{LIFE A N D WORKS}

is the fact that these nymphs are nymphs of the Tagus and that one of them, Nise again, weaves a picture of the city of Toledo in her golden tapestry. Finally the use of this device of the nymphs, their number, and the appearance of the two shepherds at the close of the poem must all have some particular significance and in some way pay tribute to the María who received the poem.

All of these conditions are satisfied if the María is Doña María Osorio Pimentel, wife of his patron, Don Pedro de Toledo. ${ }^{1}$ Of the poet's long intimacy with Don Pedro we have had frequent occasion to speak. During his brief residence in Toledo before I 532, his house adjoined that of Don Pedro and Doña María and he must have had every opportunity to become intimate with their family, consisting of four daughters, Leonor, Juana, Ana, and Isabel, and several sons, of whom at least two, Don Fadrique and Don García, were with their father in Naples, where this old friendship was no doubt continued. Under

\section{A N D MONOGRAPH S}




\begin{tabular}{|l|l|}
\hline GARCILASO DE LA VEGA \\
\hline $\begin{array}{l}\text { these circumstances, what more fitting } \\
\text { tribute could he pay to a mother than to } \\
\text { present her children in the guise of nymphs } \\
\text { and singing swains? What more effec- } \\
\text { tive reference could he make to their com- } \\
\text { mon love of Toledo than to picture it in } \\
\text { the work of one of these nymphs What } \\
\text { could have been more natural than that } \\
\text { he should have confided the story of his } \\
\text { grief to his favorite among this family of } \\
\text { girls, who had been playmates with him } \\
\text { in the old days at home? Finally, in whom } \\
\text { among all his circle of acquaintance could } \\
\text { he have found a more friendly protectress } \\
\text { than in the wife of his life-long patron ? } \\
\text { The terms in which he addressed his } \\
\text { patroness are of especial interest, for } \\
\text { they make clear in this, the last of his } \\
\text { works, the same devotion to letters in the } \\
\text { midst of war which he had shown in his } \\
\text { Elegy to Boscán. Our admiration for his } \\
\text { high gifts can only be enhanced by the } \\
\text { consideration that this poem, written per- } \\
\text { haps during the period of waiting before the } \\
\text { passage of the Alps into France, could }\end{array}$ \\
\hline $\begin{array}{l}\text { H I S P A N I C N O T E S } \\
\text { - }\end{array}$ \\
\hline
\end{tabular}




\section{IFE A N D W ORK S}

never have received the final polish of his hand, but stands to-day as he wrote it,

entre las armas del sangriento Marte.

The device which Garcilaso uses as a background for his poem is one suggested by Sannazaro in the last prosa of the Arcadia. Four nymphs issue from the Tagus and after sporting for a moment in the river and on the shore, start to embroider certain tapestries, woven with threads of gold from the stream. The themes of the work of the first three, described in detail by the poet, are familiar classical myths: the stories of Orpheus and Eurydice, of Apollo and Daphne, and of Venus and Adonis. The last of the nymphs, Nise, weaves a more personal story; with a view of Toledo in the background, she shows a funeral gathering on the banks of the Tagus, a company of nymphs who have come to pay the last rites to a maiden, whose epitaph they carve upon a tree. The maiden is Elisa, beloved of Nemoroso, whose song of grief must ere this have

\section{A N D MONOGRAPH S}




\begin{tabular}{|c|c|}
\hline 260 & GARCILASO DE LA VEGA \\
\hline & $\begin{array}{l}\text { reached her home in Portugal. Thus to } \\
\text { the very end of his life, Garcilaso found in } \\
\text { Doña Isabel Freire the inspiration for his } \\
\text { verse. } \\
\text { The sun is setting and the nymphs, } \\
\text { dropping their tasks, are preparing to re- } \\
\text { turn to the river, when they are stopped by } \\
\text { the sound of pan's-pipes. In a moment } \\
\text { two shepherds appear, Tirreno and Alzino, } \\
\text { and, like Corydon and Thyrsis in Virgil's } \\
\text { seventh Eclogue, they begin an amoebean } \\
\text { competition in praise of their mistresses, } \\
\text { Flerida and Phyllis. Their songs are } \\
\text { thoroughly conventional, almost translated } \\
\text { from Virgil. When they have ended, they } \\
\text { start again on their way and the nymphs, } \\
\text { at the sound of their approach, disappear } \\
\text { beneath the waters of the stream. The } \\
\text { third line from the end is imperfect. Death } \\
\text { interrupted the task. } \\
\text { Although the poem is called an Eclogue, } \\
\text { there is little of the pastoral about it, save } \\
\text { the formal responsive songs at the end. } \\
\text { The rest is either mythological or allegor- } \\
\text { ical. While in artistic merit it falls far below }\end{array}$ \\
\hline & H I P A N I C N T ES \\
\hline
\end{tabular}




\section{LIFE A N D W O R K S}

the first of the Eclogues, it remains a poem of fine workmanship and in some respects offers the most perfect example of Garcilaso's mastery of the cadence of the hendecasyllable. His octave is a sonorous instrument, infinitely more supple and effective than that of Boscán and a worthy model for the poets of the succeeding generation.

\section{GARCILASO'S LYRIC ART.}

Garcilaso is not a poet of many moods; the strings of his lyre are few. In vain shall we seek in him the passionate fire of Catullus or the good-humored geniality of Horace. Nor do we find any of the mystic aspiration toward eternity which transports a Luis de León or a San Juan de la Cruz. The burden of his song is simple: life's path is a way of futile striving and of disappointment. Love is in vain; death is the great healer. There is no cynicism in his retrospective glance, only a vaguely wistfful regret, a tender melancholy. In this respect he is closely akin to Virgil in the eclogues and to Sanna-

\section{A N D MONOGRAPHS}




\begin{tabular}{|c|c|}
\hline 262 & GARCILASO DE LA VEGA \\
\hline & $\begin{array}{l}\text { zaro, his two great masters. His Petrarchan } \\
\text { mood is less sincere, for his spirit was less } \\
\text { given to subtle analysis than to a quiet } \\
\text { delight in the memory of his misfortunes. } \\
\text { His few pictures of the heroic struggles of } \\
\text { war are stilted and artificial. But within the } \\
\text { limited confines of his special talent, the } \\
\text { simple portrayal of human regretand sorrow, } \\
\text { he has few equals in the world's literature. } \\
\text { With this subtle power to touch the } \\
\text { heart of the world with a sense of his per- } \\
\text { sonal sorrow goes hand in hand an ex- } \\
\text { quisite taste and a perfect form. Working } \\
\text { in a medium which was new and strange, } \\
\text { with no models to follow in the diction of } \\
\text { his own Castilian speech, he created a } \\
\text { Spanish lyric diction. For such a task } \\
\text { he was happily equipped. His stout Cas- } \\
\text { tilian past gave him a poise and dignity; } \\
\text { his close contact with Italy added to his } \\
\text { instrument the qualities of elegance and } \\
\text { polish. The result of these two influences } \\
\text { is a style which is at once distinguished } \\
\text { and supple, free from the rigidity of his } \\
\text { own speech and also free from the extrav- }\end{array}$ \\
\hline & H I S P A I C NOTES \\
\hline
\end{tabular}




\section{LIFE A N D W ORKS}

agances of his Italian contemporaries. In the delicacy of his finish, in the purity and simplicity of his lines there is a quality like that of some exquisite plateresque carving.

There have been those who have sought to find in his work traces of that conscious effort for subtlety which led in time to the excesses of Góngora and his perverted school. Such a charge implies an ignorance of the poetry of the cancioneros and of the Italian poets of his time. Compared with Juan de Mena or Angelo di Costanzo, Garcilaso is classical in his purity and simplicity. Such he was considered to be by Lope de Vega, by Quevedo, and by all the other opponents of the school of $\mathrm{cul}$ teranismo, who turn to him as a model of sound writing and good taste. This good taste is unfailing in his work; his feeling for the fitting expressing is never questionable. It is not the least of the tributes which are paid to his achievement that to-day his works seem more modern in their style and language than any of the works of the sixteenth century.

\section{A N D M O N O G A P H S}




\begin{tabular}{|c|c|}
\hline 264 & GARCILASO DE LA VEGA \\
\hline & $\begin{array}{l}\text { Not the least of his gifts, certainly the } \\
\text { one which has insured him the unswerving } \\
\text { admiration of his own people through the } \\
\text { centuries, is his incomparable gift of song. } \\
\text { Oviedo, it will be recalled, styled him a } \\
\text { "gentil musico"; that power was trans- } \\
\text { lated into his work. Nowhere in Castilian } \\
\text { can there be found such music, such } \\
\text { variety of tone and color, such appealing } \\
\text { melody. To have enriched the life of his } \\
\text { nation with this gift is alone a warrant for } \\
\text { his enduring fame. But Garcilaso is more } \\
\text { than an object of national pride; he is a } \\
\text { source of permanent delight for all the } \\
\text { world whose speech is Spanish. And hap- } \\
\text { pily, this gift of song is not one that ap- } \\
\text { peals merely to the trained mind; it still } \\
\text { stirs all men who love the song of birds, } \\
\text { the rustle of wind in the trees or the bab- } \\
\text { bling of brooks. Thus Garcilaso's in- } \\
\text { fluence and popularity have been universal. } \\
\text { We do not need to know the source of his } \\
\text { themes to be stirred by the magic of his } \\
\text { words. His art of song is spontaneous and } \\
\text { eternal. }\end{array}$ \\
\hline & H I P A N I N N T E \\
\hline
\end{tabular}




\section{LIFE A N D WORKS}

\section{CHAPTER II \\ THE LETTERS}

Of the three letters of Garcilaso which have come down to us as evidences of his prose, one is a brief official note sent to the Emperor concerning a military matter. The second is a short, friendly missive to Girolamo Seripando, interesting largely because of an unexplainable reference to certain enmities at the Court. The third letter, however, is considerably longer and offers a larger interest.

This letter, the first of Garcilaso's works to appear in print, is addressed to Dona Gerónima Palova de Almogavar and serves as a prologue to Boscán's translation of Il cortegiano of Baldassare Castiglione. It was Garcilaso, as Boscán tells us in his own Prólogo, ${ }^{1}$ who first sent him a copy of the Italian work and it was he who, after the translation had been made at

\section{A N D M O N G R A P H S}




\begin{tabular}{|c|c|}
\hline 266 & GARCILASO DE LA VEGA \\
\hline & $\begin{array}{l}\text { the instigation of Doña Gerónima, insisted } \\
\text { upon its immediate publication, even read- } \\
\text { ing the final proof himself. } \\
\text { There are several reflections of the poet's } \\
\text { opinions in this letter, which give us some } \\
\text { glimpse of his literary tastes, as well as } \\
\text { his general attitude toward life. Thus he } \\
\text { remarks his satisfaction in having early } \\
\text { appreciated the excellent qualities of Casti- } \\
\text { glione's work, adding a significant com- } \\
\text { ment on the importance of a gentleman's } \\
\text { avoiding all action which might tend to } \\
\text { lower his reputation on the world. Of } \\
\text { particular interest is his biting criticism of } \\
\text { early Spanish literature. "Some misfor- } \\
\text { tune has always been ours," he says, "for } \\
\text { hardly anyone has written anything in } \\
\text { our tongue which could not very well have } \\
\text { been. dispensed with." Plainly he was not } \\
\text { familiar with Juan Ruiz; the Celestina } \\
\text { he must have overlooked, or considered } \\
\text { unworthy of a place in belles lettres. In all } \\
\text { probability he is thinking primarily of the } \\
\text { novelas caballerescas, for headds, "though this } \\
\text { would be hard to prove to those who always }\end{array}$ \\
\hline & H I P A N I N N T E S \\
\hline
\end{tabular}




\section{I F E A N D W O R K}

have in hand those books that kill men." 1

Another passage of especial moment, as reflecting his own methods, is his comment on the value of Boscán's translation. It is as hard, he believes, to translate a book well as to write a new book. Boscán has avoided the dangers, he has escaped affectation, without falling into dryness. His language is pure, his words are elegant, in good usage, and not new nor unfamiliar. If these are qualities of style which he admired in his friend, may we not suppose that they were also those which he sought himself to achieve? And in fact, are not these precisely the qualities which critics have found in his works? Continuing, he praises the translator for his skill in translating, not the words, but the spirit and ideas of the original, achieving the same effects of force or ornament by following different paths. Here once more we have a statement of his own practice, which he has so admirably illustrated in his translation of Sannazaro in the second Eclogue.

\section{A N D MONOGRAPHS}




\begin{tabular}{|c|c|}
\hline 268 & GARCILASO DE LA VEGA \\
\hline & $\begin{array}{l}\text { His defense of Castiglione from the } \\
\text { charge of inequality in the humor of the } \\
\text { examples which he cites is not wholly con- } \\
\text { vincing, but it does bespeak the writer of } \\
\text { experience who knows the difficulty of } \\
\text { maintaining the level of inspiration, and } \\
\text { it does show a certain regard for a realistic } \\
\text { presentation of life, which is banal as well } \\
\text { as brilliant. The final reference to his own } \\
\text { share in the work must certainly be taken } \\
\text { literally. Garcilaso is in no wise respons- } \\
\text { ible for the excellencies of the translation, } \\
\text { as Navarrete suggested; it is the achieve- } \\
\text { ment of Boscán and it is unnecessary to } \\
\text { seek in it the hand of his friend. Garcilaso } \\
\text { was privileged to review it. } \\
\text { As Menéndez y Pelayo has fitly re- } \\
\text { marked, few works have been honored with } \\
\text { a prologue more subtly and discreetly } \\
\text { phrased, nor more delicately fitted to their } \\
\text { subject. Garcilaso's prose, like his verse, } \\
\text { is polished and elegant; far more than his } \\
\text { verse it shows the gracious dignity of old } \\
\text { Castilian. If it lacks the simplicity of the } \\
\text { prose of his great contemporary, Juan de }\end{array}$ \\
\hline & H I P A N I C NOTES \\
\hline
\end{tabular}




\section{I F E A N D W O R K S}

Valdés, it must be attributed to the artificial atmosphere of the court in which he lived. The whole letter reflects that courtly life, with its elaborate compliments and tributes, often too overdrawn for the tastes of modern life. But the Garcilaso whom we see is quite the same gallant gentleman who moves through the verses he has left: polished and subtly wellbalanced, himself a model of the cortegiano.

\section{A N D MONOGRAPHS}




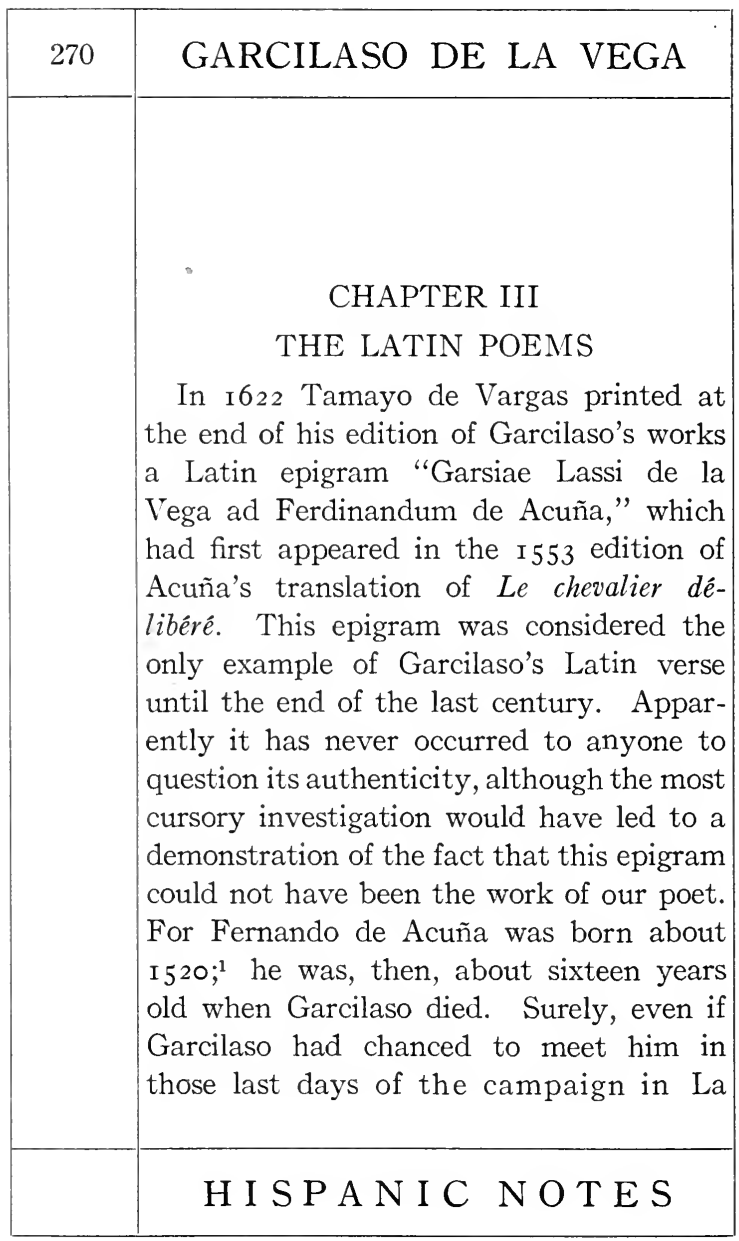




\section{IFE A N D W ORK S}

Provence, where Acuna joined the Imperial forces a few days before the poet's death - and this is highly improbable he could hardly have found in this lad a distinguished eulogist of the royal family. In fact, the first verses of Acuna to which it is possible to assign a date, and these are all amorous, belong to the period between I 537 and I540. His famous sonnet to the king,

Ya se acerca, señor, o es ya llegada la edad gloriosa, en que prometè el cielo una grey y un pastor solo en el mundo... un monarca, un imperio, $y$ una espada,

$$
\text { (lines } 1-3,8)^{1}
$$

can hardly have been written before the battle of Mühlberg ( $\left.\mathrm{I}_{547}\right)$. The translation of Le chevalier délibéré, undertaken at the request of Charles $\mathrm{V}$, and dedicated to him, was certainly written long after Garcilaso's death.

Under these circumstances, it is plain that the Garcilaso who wrote the epigram was not our poet but his son of the same name. This son enjoyed a reputation as

\section{A N D M O N O R A P H S}




\begin{tabular}{|c|c|}
\hline 272 & GARCILASO DE LA VEGA \\
\hline & $\begin{array}{l}\text { a poet, for he is celebrated among other } \\
\text { poets of the decade from I } 540 \text { to I } 550 \text { by } \\
\text { Gerónimo de Urrea in the stanzas which he } \\
\text { introduced into the Canto XLV of his } \\
\text { translation of the Orlando furioso (Anvers, } \\
\text { I549), } \\
\text { Don Juan de Heredia viene muy gozoso, } \\
\text { dando mas luz al Celtiberio assiento; } \\
\text { y don Luys Chapata, desseoso } \\
\text { de ver al proprio barco en salvamiento; } \\
\text { Garcilasso no menos presuroso } \\
\text { viene, monstrando bien ser ornamento } \\
\text { de la Vega y de Cuñiga; y ufano } \\
\text { veo a Gualvez venir, junto a Morrano. } \\
\text { Diego Ramírez Pagán, in his Floresta de } \\
\text { varia poesia, dedicates to his memory a } \\
\text { sonnet in which he seems to place him be- } \\
\text { side his father in the glory of his achieve- } \\
\text { ment, } \\
\text { iO del arbol mas bello y mas gracioso } \\
\text { que ha produzido aca fertil terreno } \\
\text { rico pimpollo, ya de flores lleno } \\
\text { y a par de otra qualquier planta glorioso! } \\
\text { El mismo viento ayrado y tempestuoso, } \\
\text { que a tu tronco tan lexos del ameno } \\
\text { patrio Tago arranco, por prado ageno }\end{array}$ \\
\hline & H I S A N I C NOTES \\
\hline
\end{tabular}




\section{I F E A N D W ORK S}

te deshojo con soplo pressuroso;

y una misma tambien piadosa mano hos traspuso en el cielo, a do las flores de ambos produzen ya agradable fruto.

No hos llore, como suele el mundo en vano,

mas consagreos altar, offrezca olores, con rostro alegre $\mathrm{y}$ con semblante enxuto. ${ }^{1}$

It is also probable, as we have seen, that some other works preserved under the name of Garcilaso de la Vega are his.

Although this epigram is not the work of Garcilaso, other of his Latin poems have survived. As long ago as 1762 there was printed at Naples in the edition of the Opera of Antonius Thylesius an ode of undoubted authenticity addressed by Garcilaso to Thylesius in honor of his Latin play, the Imber aureus (I529). Since the discovery of this poem by Signori Mele and Savj-Lopez in 1897 , two other of his Latin odes have been found and printed by Signor Mele and Señor Bonilla y San Martín, so that we may now form some opinion of his Latin style.

\section{A N D M O O GRAPH S}




\begin{tabular}{|c|c|}
\hline 274 & GARCILASO DE LA VEGA \\
\hline & $\begin{array}{l}\text { It must be confessed that none of these } \\
\text { three poems reveals exceptional worth; in } \\
\text { ease and mastery of form they cannot be } \\
\text { compared with the work of Pontanus } \\
\text { or even of Sannazaro or Navagero. Of } \\
\text { classic reminiscences there are many, par- } \\
\text { ticularly of Virgil and Horace; the versi- } \\
\text { fication is for the most part technically } \\
\text { perfect; and occasionally there is a line of } \\
\text { real beauty or power. But as a whole they } \\
\text { smack rather of the school-boy exercise, of } \\
\text { conscious effort to use an artificial, un- } \\
\text { familiar form. } \\
\text { It seems improbable that it was one of } \\
\text { these odes which was dedicated to Cardinal } \\
\text { Bembo and of which the latter spoke in } \\
\text { terms of such unmeasured praise. It may } \\
\text { well be true that Garcilaso's odes surpassed } \\
\text { those of any of the Spaniards of his time; } \\
\text { but it is also probable that they were the } \\
\text { only Latin poems written by a Spaniard } \\
\text { which Bembo had ever seen. Nor must } \\
\text { it be forgotten that in the same letter in } \\
\text { which he bestows such enthusiastic praise, } \\
\text { he also has a special and personal favor to }\end{array}$ \\
\hline & H I S A N I C NOTES \\
\hline
\end{tabular}




\section{I F E A N D W O R K S}

ask in behalf of his friend Onorato Fascitelli. We can only say that if Bembo's judgment was a candid, honest expression of his opinion, then the poems to which he refers must have been other than those which have survived.

Quite apart from their literary value, a certain personal interest attaches to the odes to Thylesius and Sepúlveda. The former, in particular, contains explicit references to the poet's stay in Germany and to the new friends and experiences that he was enjoying in Naples, as well as the only mention of his wife in all his writings. The latter, although more conventional in its subject matter, testifies to his acquaintance with the historian of Charles $V$ and gives an interesting reference to the latter's Democrates. The third of the odes is a typical product of the Renaissance: a pot-pourri of classical reminiscences of the power of Cupid, decked in the form of a dialogue between Venus and her son, wholly without emotion, unrelieved even by the exquisite artistic finish which the

\section{A N D MONOGRAPHS}




\begin{tabular}{|l|l|}
\hline GARCILASO DE LA VEGA \\
\hline $\begin{array}{l}\text { masters of this school of imitation suc- } \\
\text { ceeded in giving to their verse. Without } \\
\text { these works we knew that Garcilaso was } \\
\text { steeped in the classic Latin poets; through } \\
\text { them we see that he, like the other poets } \\
\text { of his time, regarded Latin as a language } \\
\text { for actual use as an artistic instrument; } \\
\text { they make it easier to understand the } \\
\text { close affinity which exists between him and } \\
\text { Virgil in the Eclogues. He belongs to that } \\
\text { great group of the scholar-poets of the } \\
\text { Renaissance. }\end{array}$ \\
\hline H I S A N I C O T E S \\
\hline
\end{tabular}




\section{I F E A D W O R K}

\section{CHAPTER IV \\ VERSIFICATION}

Garcilaso's position as an innovator in poetical form gives especial significance to the technical methods which he followed in these new forms, for it was his verse, rather than that of Boscán, which was the model of the early members of the Italian school in Spain, and as we shall see, it is he who offers the first example of the use of many of the Italian metrical combinations. ${ }^{1}$

The much discussed question of the first appearance in Spain of the hendecasyllable and of the Italian verse forms, which has been reviewed at length by Menéndez y Pelayo in his study of the work of Boscán, ${ }^{2}$ does not concern us here. Although there can be little doubt that sporadic lines in the Italian rhythms are to be found in writers of the Middle Ages

\section{A N D MONOGRAPH S}




\begin{tabular}{|c|c|}
\hline 278 & GARCILASO DE LA VEGA \\
\hline & $\begin{array}{l}\text { in Spain, or that the Marquis of Santillana } \\
\text { and Juan de Villalpando made a conscious } \\
\text { effort to imitate the sonnets of Dante, } \\
\text { their work has no relation with that of } \\
\text { Garcilaso. His source of inspiration is not } \\
\text { the literature of his own tongue but that } \\
\text { of Italy, to which he was led by circum- } \\
\text { stances which we have already discussed. } \\
\text { Nor need we attempt to survey the history } \\
\text { of the development of the several measures } \\
\text { which became the standard rhythms of } \\
\text { Italian verse. It is sufficient to say that } \\
\text { Garcilaso's model for his versification, as } \\
\text { for his artistic methods, was Petrarch. } \\
\text { a. THE HENDECAsyLLABLE } \\
\text { The hendecasyllable of Garcilaso is that } \\
\text { of Petrarch in its two normal forms, the } \\
\text { one with stresses on the sixth and tenth } \\
\text { syllables, } \\
\text { El dulce lamentár de dos pastóres, } \\
\text { the other with stresses on the fourth, } \\
\text { eighth and tenth syllables, } \\
\text { iO dulces préndas, por mi mál falládas! } \\
\text { (Son. X, 1) }\end{array}$ \\
\hline & H I S A N I C NOTES \\
\hline
\end{tabular}




\section{I F E A N D W O R K S}

Without counting the lines with inner rhymes, in which there is an enforced stress on the sixth syllable, the first of these two types largely predominates. In his use of the minor accents there seems to be no general rules except the introduction of at least one minor stress before the sixth syllable in verses of the first type and the avoidance of minor stresses ("acentos obstruccionistas") on the fifth syllable in verses of the first type, and on the third and seventh syllables of the second type (that is, before the secondary line-stresses) and on the ninth syllable in verses of both types (that is, before the main line-stress). ${ }^{1}$ In general it may be said of his verse, and this has already been remarked as characteristic of the poets of the sixteenth century in Spain by Rodríguez Marín, ${ }^{2}$ that it has a strongly marked iambic rhythm. Wholly iambic lines are not uncommon,

El cièlo quànto bién conòce el múndo,

(Son. XXI, 2)

\section{A N D MONOGRAPH S}




\begin{tabular}{|c|c|}
\hline 280 & GARCILASO DE LA VEGA \\
\hline & $\begin{array}{l}\text { and lines with four iambic stresses are } \\
\text { frequent, } \\
\text { En fìn a vuèstras mános he venído, } \\
\text { (Son. II, 1) } \\
\text { A fuèrça de llorár crecèr hazía. } \\
\text { (Son. XIII, 10) } \\
\text { Although the two forms which we have } \\
\text { mentioned are the norm of Garcilaso, other } \\
\text { types, some of them employed by his } \\
\text { Italian masters, appear in his poems. In } \\
\text { the earlier Tuscan poets, lines which bore } \\
\text { a secondary stress on the fourth syllable } \\
\text { were not necessarily also stressed on the } \\
\text { eighth syllable; there was left a consider- } \\
\text { able degree of freedom in the disposition } \\
\text { of the minor stresses. One type, that with } \\
\text { a stress on the seventh syllable, is found } \\
\text { occasionally in Petrarch, and in Dante is so } \\
\text { common as to be one of his regular forms. } \\
\text { Of this type there are a number of examples } \\
\text { in Garcilaso: } \\
\text { Cortaste el árbol, con mános dañósas. } \\
\text { (Son. XXV, 3) } \\
\text { Y a ver los pássos por dó me ha traydo. } \\
\text { (Son. I, 2) }\end{array}$ \\
\hline & H I S A N I C NOTES \\
\hline
\end{tabular}




\section{LIFE AND WORKS}

Bien es verdád que no está acompañáda.

(El. I, 121)

Tus claros ójos, ¿a quién los volvíste?

(Egl. I, 12s)

Hinchen el áyre de dúlce armonía.

(Egl. II, 69)

Ora clavándo del ciérvo ligéro.

(Egl. II, 194)

Verde teñída, aquel válle atajávamos.

(Egl. II, 210)

Y caminándo por dó mi ventúra.

(Egl. II, 539)

Como pudíste tan présto olvidárte.

(Egl. II, 5is)

iAdios, montáñas; adiós, verdes prádos!

(Egl. II, 638)

Even more common are the lines which have no stress between the fourth and tenth syllables:

- Pienso remédios en mi fantasía.

(Son. III, 6)

Libre el lugár a la desconfiánça.

(Son. IV, 4)

A poder mío y a mi consentimiénto.

(Son. VII, 10)

\section{A N D MONOGRAPHS}




\begin{tabular}{|c|c|}
\hline 282 & GARCILASO DE LA VEGA \\
\hline & 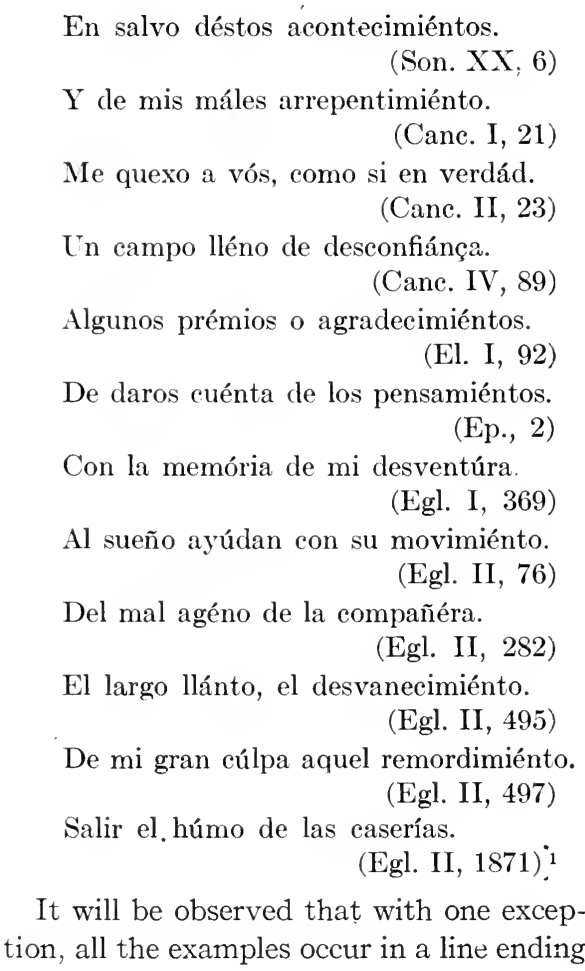 \\
\hline & H I PANIC NOTES \\
\hline
\end{tabular}




\section{LIFE A N D W ORKS}

with a word of four or more syllables, in which the eighth syllable is necessarily unstressed.

Aside from these unquestionable examples of deviation from the normal types, there are several cases in which it is necessary to place the secondary stress on a normally weak syllable, if the lines are to conform to the usual rules. Such lines as:

No pierda más, quien ha tànto perdído. (Son. VII, 1)

Me quito al múndo y me ha en tì sepultádo. (Son. XVI, 13)

En un temór que me ha puèsto en olvído. (Canc. IV, 15j)

Tentar el mál y si es màlo el sucésso.

(Egl. II, 824)

Aguas metído podrà ser que al llánto.

(El. I, 164)

should be considered in the class with accents on the fourth and seventh syllable, for the auxiliaries aver and ser are essentially atonic. ${ }^{1}$ In like manner, there is no normal stress between the fourth and tenth syllables in the lines:

\section{A N D M O N O R A P H S}




\begin{tabular}{|c|c|}
\hline 284 & GARCILASO DE LA VEGA \\
\hline & 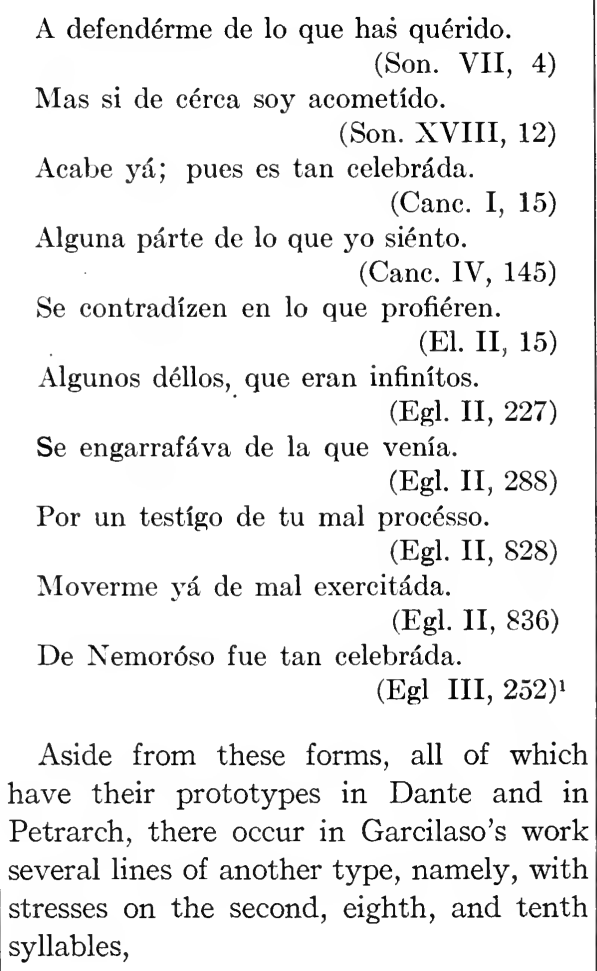 \\
\hline & H I PANIC NOTES \\
\hline
\end{tabular}




\section{LIFE A N D WORKS}

Que yá no me refrenará el temór.

(Canc. II, 36)

En lágrimas, como al lluvióso viénto.

(El. I, 23)

Descójolos y de un dolór tamáño.

(Egl. I, 35.)

Juntándolos, con un cordón los áto.

(Egl. I, 363)

Mas tódo se convertirá en abrójos.

(Egl. III, 343)

Irregular as they are, and foreign to that conception of the hendecasyllable which divides it into phrases of seven and four, or of five and six syllables, it is noteworthy that the number of syllables between the stresses is no greater than in the type whose first stress falls on the sixth syllable, or that with stresses on the fourth and tenth syllables, and that the rhythm of the line as a whole is equally well preserved.

It is interesting to note that of the examples of variation from the two common Petrarchan types, only one is from the last of Garcilaso's longer poems, Eclogue III. We may well believe that had he

\section{A N D MONOGRAP H S}




\begin{tabular}{|c|c|}
\hline 286 & GARCILASO DE LA VEGA \\
\hline & $\begin{array}{l}\text { lived to prepare his works for publication, } \\
\text { he would have pruned away many of the } \\
\text { irregularities of his first attempts with } \\
\text { that same meticulous care which character- } \\
\text { ized his Italian contemporaries. But this } \\
\text { was not permitted to him and such changes } \\
\text { as may have been made by his literary } \\
\text { executor, Boscán, were not likely to pro- } \\
\text { duce verses of purely Italian cadence, if } \\
\text { we may judge from the latter's own com- } \\
\text { positions. The fact remains, however, } \\
\text { that Garcilaso's technique was not perfect, } \\
\text { as the editions which his annotators pre- } \\
\text { pared have led us to believe. His verses } \\
\text { show precisely the uncertainties and hesi- } \\
\text { tations which we should expect to find in } \\
\text { a beginner. } \\
\text { It is not surprising, then, to find in his } \\
\text { verses several types which reveal the in- } \\
\text { fluence of his own Castilian measures. In } \\
\text { the edition of Barcelona there are at least } \\
\text { twenty-three lines of twelve syllables, } \\
\text { which may be grouped as follows: } \\
\text { (a) Lines composed of a verse of re- } \\
\text { dondilla mayor, followed by its quebrada, }\end{array}$ \\
\hline & H I S A N I C NOTES \\
\hline
\end{tabular}




\section{I F E A N W ORKS}

Esfuerça con la miseria | de tu estado. (Son. IV, 7)

Encuentrase en el camino | facilmente.

(Son. VIII, 5)

$\mathrm{Y}$ ansi ando con lo que siento | differente. (Son. IX, 8)

Quanto el fiero Faderique | de Toledo.

(Egl. II, 1213)

Puesque no la ha quebrantado | tu partida.

(Egl. I, 266)

Donde descansar y siempre | pueda verte. (Egl. I, 405)

A lo menos aprovecha $\mid$ yo te digo.

(Egl. II, 352)

Como si yo fuesse un leño | sin sentido. (Egl. II, 989)

Aviendo ya contemplado | una gran pieça. (Egl. III, 81)

Recogido le llevavan | alegrando.

$$
\text { (Egl. III, 294) }
$$

(b) Lines composed of a verse of redondilla mayor, agudo, followed by a quintanary (five-syllable line):

He perdido quanto bien / de vos espero. (Son. IX, 7)

El alamo y el laurel | y el mirtho callen. (Egl. III, 360)

\section{A N D MONOGRAPH S}




\begin{tabular}{|c|c|}
\hline 288 & GARCILASO DE LA VEGA \\
\hline & 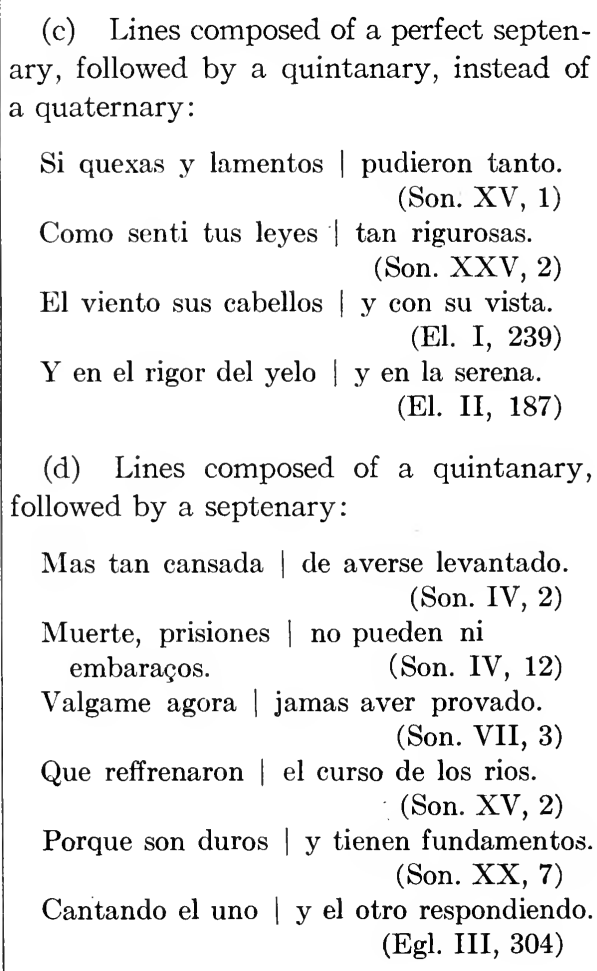 \\
\hline & H I PANIC NOTES \\
\hline
\end{tabular}




\section{I F E A N D W O R K S}

In lines such as those of (a) and (b), the rhythm of the line is frankly trochaic in several of the examples and they seem to reveal the influence of the normal Castilian verse. It may be remarked that the lines in group (d) also have stresses without exception on the seventh syllable and should perhaps be included with those of (a) and (b). In the lines of groups (c) and (d), it is probable that the syllable after the stress was felt as hypermetric. Such a usage, natural in Spain, where it was an essential feature of the verses of arte mayor, is not without its counterpart in the Italian poets. Thus we find numerous examples in the work of the fifteenth century Neapolitan poet, Francesco Galeota, especially in his Frotola in gliomaro, as,

Ho presso alquanto ardire | de basso inzegno. ${ }^{1}$

Neither the gliommero nor the arte mayor seem ever to have lost their character of two distinct lines within a single lira.

\section{A N D M ONOGRAPH S}




\begin{tabular}{|c|c|}
\hline 290 & GARCILASO DE LA VEGA \\
\hline & $\begin{array}{l}\text { When the first half-line ended, and the } \\
\text { second half-line began, with a vowel, a } \\
\text { septenary and a quintanary or a quintanary } \\
\text { and a septenary together formed a perfect } \\
\text { hendecasyllable. And this happened so } \\
\text { frequently in practise, that it became the } \\
\text { rule. Garcilaso's use of the two half-lines } \\
\text { independently may be traced in part to } \\
\text { the native usage in this respect and in } \\
\text { part to his acquaintance with the Neapol- } \\
\text { itan school. } \\
\text { It is not surprising, either, that we should } \\
\text { find in his work a few examples of actual } \\
\text { lines of arte mayor, } \\
\text { La fuérça de en quién / ha de essecutárse. } \\
\text { (Canc. I, 16) } \\
\text { Bramándo paréce I que respondían. } \\
\text { (Egl. II, 513) } \\
\text { Lines of eleven syllables are naturally } \\
\text { frequent in the verses of arte mayor of } \\
\text { Juan de Mena and the other masters of } \\
\text { the form and in the works of Boscán they } \\
\text { constantly appear to disturb the rhythm } \\
\text { of his verse. }\end{array}$ \\
\hline & H I P A N I N NTES \\
\hline
\end{tabular}




\section{IF E A N D W O K S}

291

In the canciones there appear two lines of nine syllables,

He lastima que van perdidas.

Fueren de alguno enfin halladas.

(Canc. III. 64)

where the stanza structure calls for a hendecasyllable. Their occurrence in the canciones alone, amid hendecasyllables and septenaries, would arise not unnaturally from the uncertainty incident to the use of this little practised form.

As for the septenaries of Garcilaso, they offer no peculiarity worthy of comment, other than a tendency to preserve a strictly iambic rhythm. Lines such as

Ni con frèno la ríge. (Canc. V, 39) are rare.

b. SYNAERESIS AND DIAERESIS

The. practice of the Castilian poets before the sixteenth century in regard to

\section{A N D M O N G R A P H S}




\begin{tabular}{|c|c|}
\hline 292 & GARCILASO DE LA VEGA \\
\hline & $\begin{array}{l}\text { synaeresis, diaeresis, synaloepha and hiatus } \\
\text { had been extremely irregular and it is not } \\
\text { to them but rather to the Italian models } \\
\text { of Garcilaso that we must look to find the } \\
\text { general principles on which he based his } \\
\text { practise. But we must also bear in mind } \\
\text { the characteristic differences in pronun- } \\
\text { ciation between Tuscan and Castilian to } \\
\text { explain those rules in which he diverges } \\
\text { from his models. For the sake of clarity, } \\
\text { we shall use the term "synaeresis" to de- } \\
\text { note the pronunciation in a single syllable } \\
\text { of any two adjacent vowels within a word, } \\
\text { "diaeresis" to denote the division into two } \\
\text { syllables of any such vowels. "Syna- } \\
\text { loepha" will be used to signify the pronun- } \\
\text { ciation in a single syllable of the. final } \\
\text { vowel of one word and the initial vowel of } \\
\text { the following word; "hiatus" the division } \\
\text { into two syllables of any such vowels. } \\
\text { The general rules of Garcilaso's use of } \\
\text { synaeresis and diaeresis may be stated as } \\
\text { follows: } \\
\text { I. Any two adjacent vowels, stressed } \\
\text { on the first vowel, count as a single syllable. }\end{array}$ \\
\hline & H I P A N I N N T E S \\
\hline
\end{tabular}




\section{LIFE A N D WORKS}

When the combination is one of a strong vowel $(\mathrm{a}, \mathrm{e}, \mathrm{o})$ followed by a weak vowel $(i, u)$, forming a true diphthong, the rule is followed without exception.

$\hat{a}$ - $u$ - Notable causa diste. (Egl. I, I 49) ${ }^{1}$ $a-y$ - Hinchen el ayre de dulce armonia. (Egl. II, 69)

$\hat{e}-\imath$-Viene a sacarme de la deuda un dia. (Son. XXVI, I3)

$\hat{e}-y$ - Por donde vos sabeys que su processo. (El. II, 26)

ó-u - No example.

$o ́-y$ - Estoy muriendo y aun la vida temo. (Egl. I, 60)

Stressed $a$, followed by either of the strong vowels, $e$ or $o$, count as a single syllable in the only examples found:

â-e - Del caso la grandeza trae consigo. (Egl. II, I 580 $)^{2}$

â-o-Quedaos a Dios, que ya nuestros oydos. (Egl. II, 635)

It is probable that these combinations were pronounced then, as still in popular Castilian, ái and áu.

\section{A N D MONOGRAPH S}




\begin{tabular}{|c|c|}
\hline 294 & GARCILASO DE LA VEGA \\
\hline & $\begin{array}{l}\text { The combination of the identical vowels, } \\
\text { ée, is treated as a single syllable: } \\
\text { A que dessee tornar a ver un dia. } \\
\text { (Son. XXVI, I3) } \\
\text { No vee la llena plaça. (Egl. II, } 44 \text {; } \\
\text { other examples: Egl. II, I 549; } \\
\text { Egl. III, } 329,349 \text { ) } \\
\text { This usage corresponds with current pro- } \\
\text { nunciation; the group ée is either simpli- } \\
\text { fied (M.S. ve) or becomes éy (desey, crey). } \\
\text { The groups éa, éo, ia, and io in general } \\
\text { follow the rule, but with some exceptions: } \\
\text { é-a - Un rato sea de mi la grave carga. (El. } \\
\text { II, I } 70 ; \text { also: Ep., 6I; Egl. II, } \\
\text { I } 48,6 \text { I } 7,630 \text { ) } \\
\text { Exceptions: De tal arte pele-an noche } \\
\text { y dia. (Son. IX, I3; also: Egl. } \\
\text { I, I42) } \\
\text { é-o - Nunca entre si los veo sino reñidos } \\
\text { (Son. IX. I } 2 \text {; also: Egl. II, 4) } \\
\text { Exception: Aqueste es el desse-o que } \\
\text { me lleva. (Son. XXVI, I } 2 \text { ) } \\
\text { i-a - Señora mia, si yo de vos ausente. } \\
\text { (Son. IX, I; } 54 \text { examples) }\end{array}$ \\
\hline & HISPANIC NOTES \\
\hline
\end{tabular}




\section{IFE AND WORKS}

Exceptions: La dulce compañi-a amarga y dura. (Son. XVII. 7 ; also Son. XXV, го; Egl. II, 531, 623 . 793,835 ; Egl. III, I 23, I37)

$i$-o - A poder mio y a mi consentimiento. (Son. VII, I9; also: Son. VIII, 6; Canc. III, 53; Egl. II, 920, I +72 , I590, I 754; Egl. III, 20I)

Exceptions: Del seco esti-o el gran calor ardiente. (Egl. II, 234; also: Egl. II, 839, 1078. I602)

Of the fifteen cases of diaeresis in these four groups, ten occur when the stress on the first vowel is reinforced by a secondary line-stress. This treatment becomes the rule, which is followed without exception, when the word stress is reinforced by (I) a main line-stress or (2) by a secondary stress on an inner rhyme.

é-a (I) Mas elada que nieve. Galate-a. (Egl. I, 59)

(2) No example. Cf. abore: pele-an. $e ́-o$ (I) Y quanto yo escrivir de vos desse-o. (Son. $\mathrm{V}, 2$ )

\section{A N D M O N O R A P H S}




\begin{tabular}{|c|c|}
\hline 296 & GARCILASO DE LA VEGA \\
\hline & 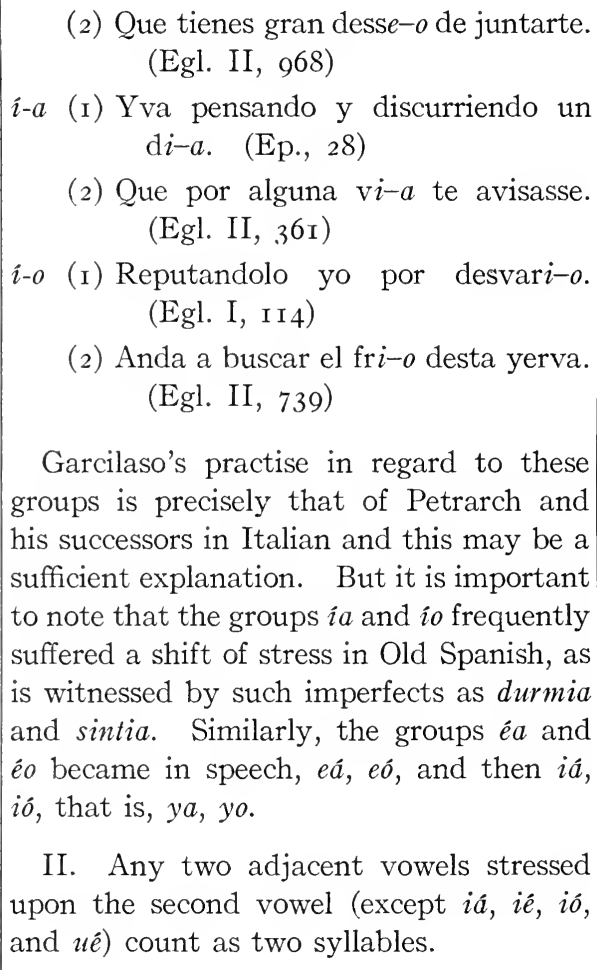 \\
\hline & H I P A N I C NOTES \\
\hline
\end{tabular}




\section{LIFE A N W W R K}

$a-e ́ e$ - Torna a ca-er, que dexa a mal mi grado. (Son. IV, 3 )

Los tiros y sa-etas ponçoñosas. (Son. XVI, 4 ; sa-eta also in Canc. $\mathrm{V}$, I02)

Para escaparse no le fue ma-estro. (Egl. II, 262; ma-estro also in Egl. II, 355, 695, 709, $7 S_{5}, 8_{41}$, I30S, I335, I622)

Yo para mi tra-er solo un cornado. (Egl. II, 899)

$a-\hat{i}$ - Y a ver los passos por do me ha $\operatorname{tr} a-y$ do. ${ }^{1} \quad$ (Son. I, 2; tra-ydo also in Egl. II, 72I)

La qual a un llano grande yo trahia.11 (Egl. II, 266; tra-hia also in Egl. II, I273, I355; Egl. III, 22I)

$\mathrm{Y}$ en torcidas $\mathrm{r} a-y$ zes se bolvian. (Son. XIII, 8; ra-yzes also in Canc. IV, 75; Egl. III, I65)

De perseguir al triste y al ca-ydo. (Canc. I, 36; ca-ydo also in Egl. II, 852) 


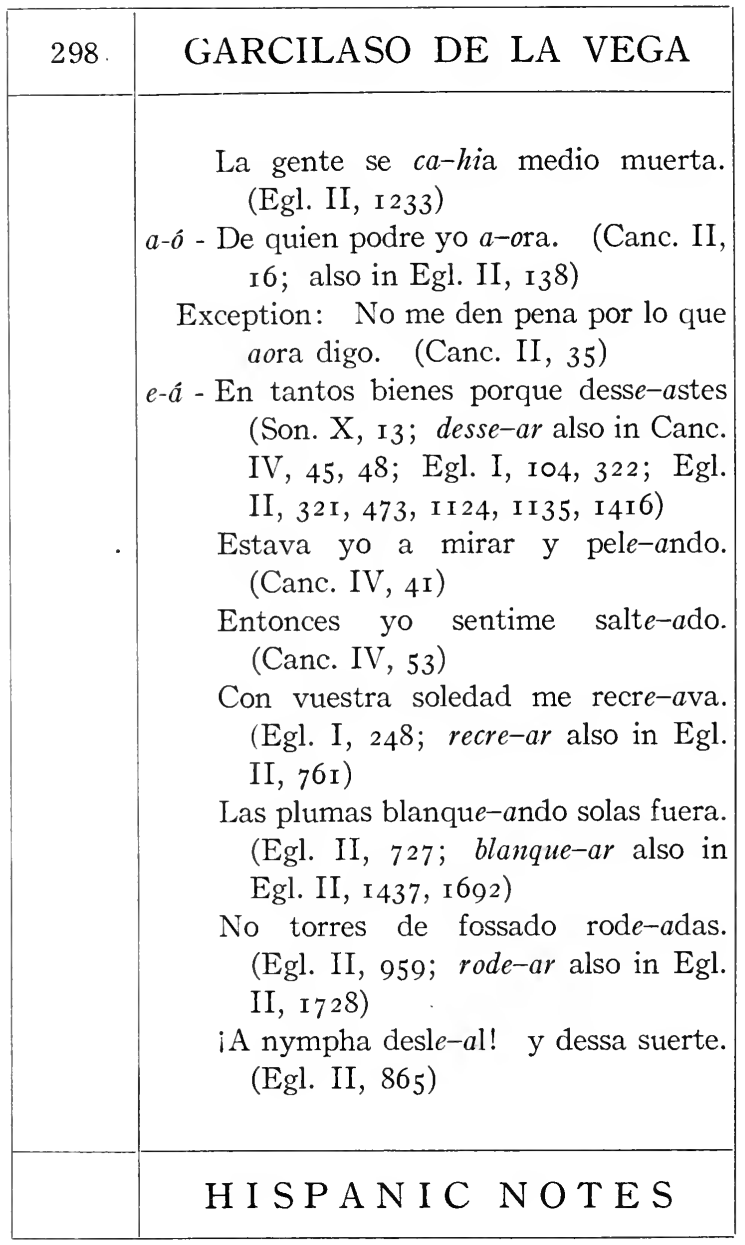




\section{IFE A N D W ORK S}

Quanto señore-aron de aquel rio. (Egl. II, I 80 )

Hazia el agua se fueron passe-ando. (Egl. III, 280)

$e-\hat{\imath}$ - En el ya se mostravan y le-hian. (El. I, 7o; le-hia also in Egl. II, I 282)

La sombra se ve-hia. (Egl. I, 4I4; $v e-h i a$ also in Egl. II, I 21 5, I 272, I73I; Egl. III, 217)

$\mathrm{Y}$ en un desassossiego no cre-yble. (Egl. II, 3 I8) .

Con essa dura mano, descre-ydo.

(Egl. II, 848; descre-ida also in Egl. II, I63I)

$o$-á - El trabajo constante y tan lo-able. (Egl. II, I445; lo-able also in Egl. III, 28)

$o-\hat{e}$ - Piensas que es otro el fuego que en O-eta. (El. I, 253)

Obras y hermosura a los po-etas. (Canc. V, 105)

$o-\hat{\imath}$ - Mas nunca fue la voz dellas $o-y$ da. (Son. XXIX, II; $0-y r$ also in

\section{A N D MONOGRAPH S}




\begin{tabular}{|c|c|}
\hline 300 & GARCILASO DE LA VEGA \\
\hline & 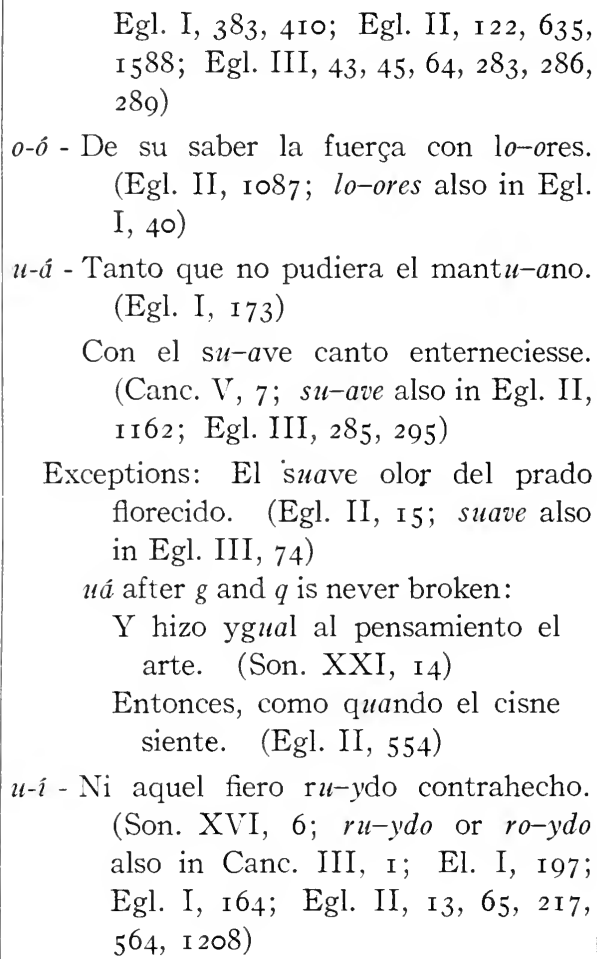 \\
\hline & H I P A N I NOTES \\
\hline
\end{tabular}




\section{LIFE A N D WORK S}

301

Mi razon y ju-yzio bien creyeron. (Canc. IV, $24 ; j u-y z i o$ also in Egl. I, I33, I36)

$\mathrm{Y}$ el passo ya cerrado y la $\mathrm{h} u-y$ da. (Canc. IV, II $2 ; h u-y r$ also in El. II, I69)

Del grave peso y de la gran $r u-y$ na. (El. I, 200; ru-yna also in Egl. II, I067)

A ser restit $u-y$ do. (Egl. I, 22; restitu-hia also in Egl. II, I468)

Exceptions: La claridad contempla, el ruydo siente. (Canc. IV, 98)

Es aqueste descuydo suelto y puro. (Ep., Io)

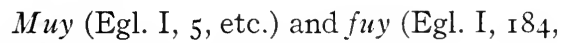
etc.) are always monosyllables; they both are properly atonic forms.

$u-o ́$ - Manso, cuerdo, agradable, virt $u-o$ so. (Egl. II, 904)

¡O gran saber! ¡O viejo frut $u-o$ so! (Egl. II, I I 29)

It is worthy of comment that all the groups mentioned in the above list are

\section{A N D MONOGRAPH S}




\begin{tabular}{|c|c|}
\hline 302 & GARCILASO DE LA VEGA \\
\hline & $\begin{array}{l}\text { either derived directly from Latin or } \\
\text { Greek, or arise from the loss of an inter- } \\
\text { vocalic consonant. }{ }^{1} \\
\text { Latin forms are: traer, recrear, man- } \\
\text { tuano, suave, virtuoso, frutuoso, ruyna, and } \\
\text { restituyr. Oeta and poeta are Greek } \\
\text { (through Latin). The following show the } \\
\text { loss of an intervocalic consonant: caer } \\
\left({ }^{*} \text { cadere), saeta (sagittam), maestro (magis- }\right. \\
\text { trum), aora (ad oram), rayzes ( }{ }^{*} \text { radices), } \\
\text { desleal ( }{ }^{*} \text { dislegalem), leer (*legére), veer } \\
\text { (videre), creyble (credibilem), loable (lauda- } \\
\text { bilem), oyr (audire), juyzio (iudicium), } \\
\text { huyr (*fugire), and ruydo (rugitum). } \\
\text { It is further interesting that with five } \\
\text { exceptions, (ma-estro, Egl. II, } 695 \text {, I335, } \\
\text { and su-ave, Canc. V, } 7 \text {; Egl. II, I } 62 \text {; Egl. } \\
\text { III, } 285 \text { ), there is no case of the diaeresis } \\
\text { of these vowels unless the stressed vowel } \\
\text { is reinforced by the main or secondary } \\
\text { line-stress. This tendency to avoid diae- } \\
\text { resis in other parts of the line is already } \\
\text { evident in the Italian poets from Dante on; } \\
\text { in Garcilaso, it becomes almost a rule. }\end{array}$ \\
\hline & H I S A N IC NOTES \\
\hline
\end{tabular}




\section{IF E A N D W O R K S}

303

The groups $i \hat{a}, i e \hat{e}$, ió, and $u \hat{e}$ call for special notice. As in the groups which we have just examined, when the combination arises from the loss of an intervocalic consonant, diaeresis occurs.

$i-\hat{a}-$ Ya de bolver estoy desconf $i-a$ do.

(Son. III, 5; desconfi-ança also in

Son. IV, 4; Canc. IV, 89; confiança in Egl. II, II93)

Fi-ar el mal de mi que lo posseo. (Son. XII, 8)

Apenas en el agua resfri-ado. (Son.

XII, I4; resfri-ado also in Egl. II, $45^{2}$; enfri-ava in Canc. IV, 40 )

Quien tras ella gui-ara ygual su curso. (Egl. II, I429; gui-ada also in Egl. II, I606)

$i-e ̂ ́-Y ~ t u$, ingrata, ri-endo. (Egl. I, 392; ri-endo also in Egl. II, 1320$)^{1}$

i-ó - No example.

$u-e ́$ - Estava en su cru-eza. (Canc. I, i I; cru-eza also in Egl. I, 382 ; Egl. II, 709, I 222)

Con processo $\mathrm{cr} u-e l$ y riguroso. (E].

I, I9I)

\section{A N D MONOGRAPHS}




\begin{tabular}{|c|c|}
\hline 304 & GARCILASO DE LA VEGA \\
\hline & $\begin{array}{l}\text { When these combinations are derived } \\
\text { from other sources, synaeresis usually } \\
\text { occurs, with certain exceptions in the case } \\
\text { of words which represent an original Latin } \\
\text { combination. } \\
\text { ia - Que aun aliviar con quexas mi cuydado. } \\
\text { (Son. II, 3; aliviar also in Egl. II, } \\
372,377, \text { I 573) } \\
\text { Por donde suelen yr las remediadas. } \\
\text { (Canc. II, Io) } \\
\text { El alma suelta con bolar liviano. (El. } \\
\text { II, I } 29 ; \text { liviano also in Egl. II, I } 477 \text {, } \\
\text { I565, I607, etc.) } \\
\text { Dellas al negociar y variando. (El. } \\
\text { II, 32) } \\
\text { Pareceme que buelo, despreciando. } \\
\text { (Egl. II, 887; despreciar also in Egl. } \\
\text { II, I522) } \\
\text { Donde el cristiano estado estava en } \\
\text { dubio. (Egl. II, I } 493 \text {; cristiano } \\
\text { also in Egl. II, I } 98 \text { ) } \\
\text { Denunciava el aurora ya vezina. } \\
\text { (Egl. II, 55I) } \\
\text { Escurecerse toda y enturviarse. (Egl. } \\
\text { II, 8) }\end{array}$ \\
\hline & H I P A N I NOTES \\
\hline
\end{tabular}




\section{LIFE AND WORKS}

Que de los tierros ramos van rumiando. (Egl. II, I733)

Exceptions: Que en imaginacion tan vari-able. (Canc. IV, I 22)

Dellas al negociar y vari-ando. (El. II, 32; vari-ar also in Egl. II, 447 , I685, 946; Egl. III, I72, 265)

A los hombres reserva, tu, Di-ana. (Egl. II, 740; Di-ana also in Egl. II, I $73,752,802$ )

A los que le cri-avan. Luego estava. (Egl. II, I307; cri-aņ̧a also in Egl. II, I34I)

Que el agua disponia al gran vi-aje.

(Egl. II, I603; vi-aje also in Egl. II, I 469 )

El cauto Itali-ano nota y mira. (Egl. II, I545)

Phillodoce, Di-amane y Climene. (Egl. III, 55; Di-amene also in Egl. III, I45)

Por el hervor del sol demasi-ado. (Canc. I, 2)

All of these words, except criar and demasiado, represent an original Latin

\section{A N D MONOGRAPH S}




\begin{tabular}{|c|c|}
\hline 306 & GARCILASO DE LA VEGA \\
\hline & $\begin{array}{l}\text { combination; criar shows a similar com- } \\
\text { bination in Latin creare, and demasiado is } \\
\text { based on demasia. } \\
\text { Of greater significance is the fact that } \\
\text { Petrarch has diaeresis in vari-are, (Son. } \\
\text { CCCV, I3), Di-ana (Madr. I, I), cre-are } \\
\text { (Canz. XXIX, Io8), and vi-aggio (Son. } \\
\text { LXII, Io). On the other hand none of } \\
\text { the words in which synaeresis occurs in } \\
\text { Garcilaso have cognate forms in Dante or } \\
\text { Petrarch, except cristiano, which occurs, } \\
\text { also with synaeresis, in Petrarch's Trionfo } \\
\text { della fama, (II, I } 42 \text { ). Finally it should be } \\
\text { noted that in every case where diaeresis } \\
\text { occurs, the word-stress is reinforced by the } \\
\text { main or secondary line-stress. } \\
\text { ió - Mi inclinacion, con quien ya no porfio. } \\
\text { (Son. VI, I } 2 \text {; also in the ending -ión } \\
\text { without exception) } \\
\text { Del oro se escogio con buelo presto. } \\
\text { (Son. XXIII, 6; also in the verbal } \\
\text { ending -ió without exception) } \\
\text { Y en lo secreto sabe Dios en quanto. } \\
\text { (El I, I } 4 \text {; Dios and diosa without } \\
\text { exception) }\end{array}$ \\
\hline & H I S P N I C NOTES \\
\hline
\end{tabular}




\section{I F E A D W O R K S}

Por manos de Vulcano artificiosas. (Son. XVI, 3; also in the ending -ioso in curioso, (Ep., II; Egl. II, I 736); codicioso (Ep., 75); embidiosa (El. I, 98); espaciosa (Egl. II, I043); gracioso (El. I, 235; Egl. I, 278; Egl. II, I048); ocioso (Son. XXVI, 5 ; Egl. II, 237); lluvioso (El. I, 23); and ravioso (Egl. III, I 80)

Respuesta tan azeda y tan odiosa. (Egl. II, 403)

Exceptions: No las francesas armas odi-osas. (Son. XVI, I; odi-oso also in Egl. III, I60)

Convertida en vi-ola. (Canc. $\mathrm{V}, 28$ ) Tan glor $i-o$ sa frente. (Egl. I, 37; glori-oso also in Egl. II, I236, I694, I 759)

Odioso, viola, and glorioso are regularly found with diaeresis in the works of Dante and Petrarch. They also represent original Latin combinations.

Garcilaso's use of the combinations ia and $i o$ is distinctly at variance with that of the Italian writers, particularly that of

\section{A N D MONOGRAPH S}




\begin{tabular}{|c|c|}
\hline 308 & GARCILASO DE LA VEGA \\
\hline & 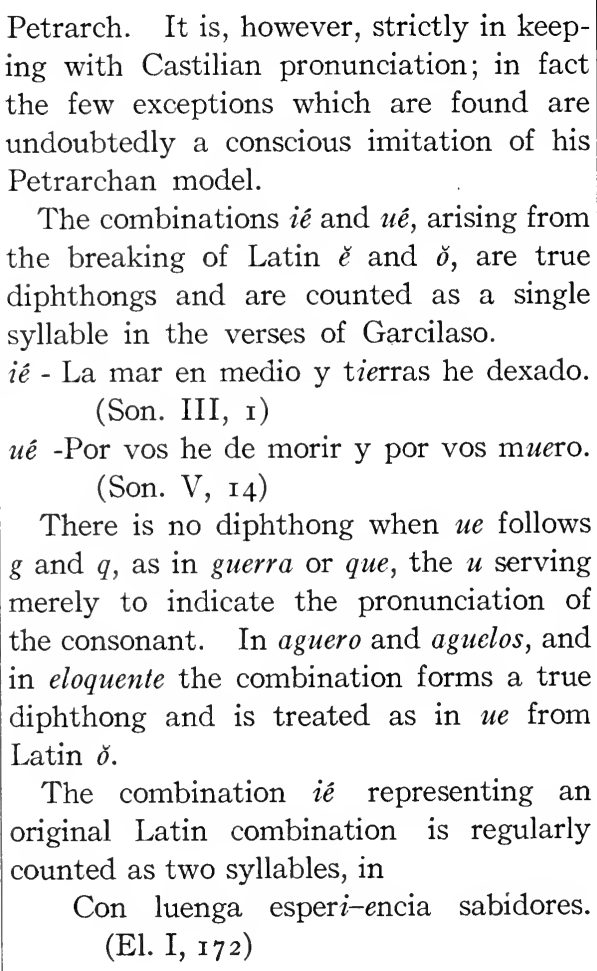 \\
\hline & H I PANIC NOTES \\
\hline
\end{tabular}




\section{LIFE A N D WORKS}

Dezildo vos, $\mathrm{P} i$-erides, que tanto. (Egl. I, 236)

Muy sin rumor, con passo muy quieto. (Egl. II, 2II; qui-eto also in Egl. II, I032)

Of the words found here, esperienza is found with diaeresis in Dante (Purg. XV, 2I) and Petrarch (Son. LXV, Io); quieto with diaeresis in Dante (Parad. XVI, I34), $^{2}$ Sannazaro (Son. XXI, I), and Ariosto (Orl. fur., XXIII, I 7, I).

The most striking features of Garcilaso's use of synaeresis and diaeresis are (I) his synaeresis of the groups éa, éo, $i a$ and $i o$, even when the word-stress is reinforced by a secondary line-stress; (2) his general avoidance of diaeresis, unless the word stress is reinforced by a main or secondary line-stress; (3) his diaeresis of all groups bearing the stress on the second vowel, used almost without exception when the group arises from the loss of an intervocalic consonant, and, also when the group represents an original Latin group, except in the groups $i a ́$, and $i o ́$. In all of these peculiari-

\section{A N D MONOGRAPHS}




\begin{tabular}{|c|c|}
\hline 310 & GARCILASO DE LA VEGA \\
\hline & $\begin{array}{l}\text { ties, two factors are evident: the influence } \\
\text { of Italian prosody and also the current pro- } \\
\text { nunciation of Castilian. Not all of his } \\
\text { rules are still preserved in Spanish versifi- } \\
\text { cation, but it is of especial interest to find } \\
\text { that they were accepted as the norm by } \\
\text { his followers in the Golden Age and that } \\
\text { even to-day evidences of their influence } \\
\text { can be found in poets of the Spanish } \\
\text { world. } \\
\text { III. Any two vowels in an unstressed } \\
\text { syllable, whether before or after the stress, } \\
\text { count as a single syllable. } \\
\text { ae- Por no morir como Phaeton en fuego. } \\
\text { (Egl. II, 303) } \\
\text { au-Señora mia, si yo de vos ausente. (Son. } \\
\text { IX, I) } \\
\text { ay - En contra puestas del ayrado pecho. } \\
\text { (Son. XVI, 2) } \\
\text { ea- Con prestas alas por la eburnea puerta. } \\
\text { (Egl. II, II 7) } \\
\text { ey - La deleytosa playa estas mirando. } \\
\text { (El. II, I } 46 \text { ) } \\
\text { ia - De tunica cubierta de diamante. (El. } \\
\text { II, 95) }\end{array}$ \\
\hline & H I S A N I C NOTES \\
\hline
\end{tabular}




\section{LIFE A N D WORKS}

En viendos la memoria de aquel dia. (Egl. II, 5)

$i e$ - Con mas piedad devria ser escuchada. (Son. XV, I 2)

Con que nunca fue a nadie defendido. (Canc. II, 4I)

io - Era prision de mas de un prisionero. (Egl. II, 265)

Salicio juntamente y Nemoroso. (Egl. I, 2)

iu - Carlo Cesar triumphante le abraçava. (Egl. II, I 503)

oo - Contandoos los amores y las vidas. (Son. XI, 8) ${ }^{1}$

$u a-\mathrm{Y}$ guarecer de un mal tan peligroso. (Son. XII, 3)

Que por dificultosa y ard $u a$ via. (Egl. II, I422)

ue - Que quien tan luengamente. (Egl. II, 689)

$u o$ - En un perpetuo marmol, de las ondas. (El. I, I6I)

$u y$ - Hacen los $\mathrm{r} u$ yseñores. (Canc. II, Io)

There is no exception to this rule in Garcilaso; it undoubtedly points to a

\section{A N D MONOGR A P H S}




\begin{tabular}{|c|c|}
\hline 312 & GARCILASO DE LA VEGA \\
\hline & $\begin{array}{l}\text { more marked tendency to equalize the } \\
\text { value of two unstressed vowels in Castilian } \\
\text { than in Italian, where we occasionally find } \\
\text { examples of the diaeresis of unstressed } \\
\text { vowels in the work of Dante and Petrarch, } \\
\text { as in tri-unfando (Petrarch, Canz. II, 8I; } \\
\text { Dante, Purg. XXVI, 77) or vari-etate } \\
\text { (Petrarch, Son. XCIX, ro). } \\
\text { c. synaLoEPHA AND HIATus } \\
\text { Synaloepha of any two adjacent vowels } \\
\text { normally occurs in Garcilaso, without } \\
\text { regard to the word-stress. } \\
\text { I. Both vowels unstressed: } \\
\text { Tu que ganaste obrando. (Egl. I, 7) } \\
\text { Either or both of the vowels may be in } \\
\text { an atonic monosyllable. } \\
\text { Por ti la esquividad y apartamiento. } \\
\text { (Egl. I, Ioo) } \\
\text { Un nombre en todo el mundo. (Egl. } \\
\text { I, 8) } \\
\text { O se cubrio de un velo. (Egl. II, } \\
687 \text { ) }\end{array}$ \\
\hline & H I S P N I C NOTES \\
\hline
\end{tabular}




\section{LIFE AND WORKS}

\section{3}

II. The first vowel stressed, the second unstressed.

O si estará ocupado o desparzido.

(El. II, 42)

The second vowel may be an atonic monosyllable.

Escucha tú el cantar de mis pastores. (Egl. I, 42)

III. The first vowel unstressed, the second stressed:

Enternecerme siento que sobre éllos. (Egl. I, 356)

The first vowel may be an atonic monosyllable.

$\mathrm{Y}$ poner fin a las querellas que úsas. (El. I, I3)

IV. Both vowels stressed:

No se que allá éntre dientes murmurando. (Egl. II, 483)

Cases of synaloepha under group IV are not frequent, but there is no case of hiatus in Garcilaso's work to avoid the synaloepha of two stressed vowels.

\section{A N D MONOGRAPHS}




\begin{tabular}{|c|c|}
\hline 314 & GARCILASO DE LA VEGA \\
\hline & $\begin{array}{l}\text { Synaloepha also occurs if the first word } \\
\text { ends in a group of two vowels, whether } \\
\text { unstressed or stressed, } \\
\text { Albanio es este que esta aqui dormido. } \\
\text { (Egl. II, 98) } \\
\text { Produze agora en cambio estos abro- } \\
\text { jos. (Egl. I, 306) } \\
\text { Que della un punto no sabia apartar- } \\
\text { me. (Egl. II, I } 8 \text { r) } \\
\text { or if the second word begins with a group } \\
\text { of two unstressed vowels, } \\
\text { La breve ausencia haze el mismo juego. } \\
\text { (El. II, 49) } \\
\text { Como si no estuviera de alli ausente. } \\
\text { (Egl. I, 53) } \\
\text { But if the second word begins with a } \\
\text { stressed group, there is hiatus in the only } \\
\text { examples found, } \\
\text { Mas inficion de äyre en solo un dia. }{ }^{1} \\
\text { (Son. VI, I } 2 \text { ) } \\
\text { Me parece que óygo que a la cruda. } \\
\text { (Egl. I, 376) } \\
\text { Que âun desto me duelo. (Canc. I, } \\
24 \text { ) }\end{array}$ \\
\hline & H I S P N I C NOTES \\
\hline
\end{tabular}




\section{LIFE AND WORKS}

although here, the hiatus is probably dependent upon another cause.

There is no example in Garcilaso of the juxtaposition of a final stressed group of two vowels and an initial stressed vowel following, nor of a final group of two with an initial group of two vowels following.

The conjunction $y$, when found between two vowels, regularly becomes semiconsonantal and prevents synaloepha. ${ }^{1}$

De la sierra de Cuenc $\dot{a} \dot{y}$ el govierno.

In three lines there seems to be a violation of this rule:

$\mathrm{Y}$ en el rigor del yelo y en la serena. (El. II, I87)

Cantando el uno y el otro respondiendo. (Egl. III, 304)

El alamo y el laurel y el mirtho callen. (Egl. III, 306).

The first of these lines is probably imperfect; in the other two, the phrase more properly calls for the omission of the $y$, which is probably an error of the printer.

Similarly, the conjunction $o$, which in speech becomes a $u$ before another vowel,

\section{A N D MONOGRAPHS}




\begin{tabular}{|c|c|}
\hline 316 & GARCILASO DE LA VEGA \\
\hline & 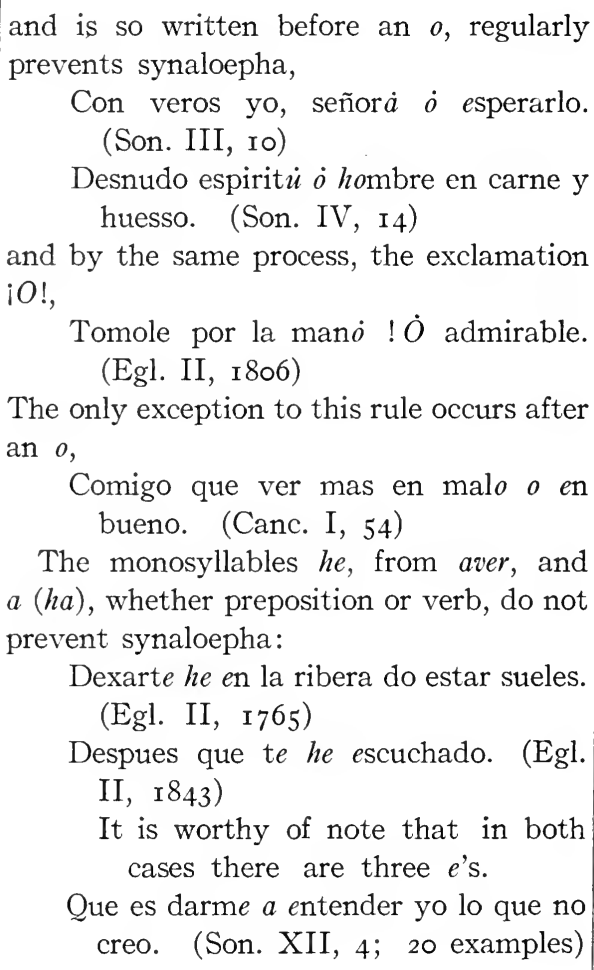 \\
\hline & H I S P A I C NOTES \\
\hline
\end{tabular}




\section{I F E A N D W O R K S}

Me quito al mundo y me ha en ti sepultado. (Son. XVI, I3)

Exceptions:

Quitalle $\dot{a}$ este mal mantenimiento. (Son. XIV, I I)

Dandome $\dot{a}$ entender que mi flaqueza. (Canc. I, 49)

Initial $h$ requires a special discussion. In the orthography of the early sixteenth century it has several meanings.

I. It may represent an original Latin $h$, never pronounced and written merely from an imitation of classical spelling. In these cases, synaloepha regularly occurs.

Humida habitaran del mar profundo. (El. I, 30); so too, ha (Egl. I, I67), Hircana (Egl. II, 563), (h)istoria ${ }^{1}$ (Egl. II, I Iо), hombre (Egl. II, 935), (h)onesto (Egl. II, 8I9), honor (Son. XXIV, I), horrible (Egl: II, I54), humana (Egl. II, Iо2), humido (Egl. II, $57 \mathrm{I}$ ).

2. It may represent a Latin initial $g$, in which case it is also silent, permitting synaloepha. ${ }^{2}$

\section{A N D MONOGRAPHS}




\begin{tabular}{|c|c|}
\hline 318 & GARCILASO DE LA VEGA \\
\hline & 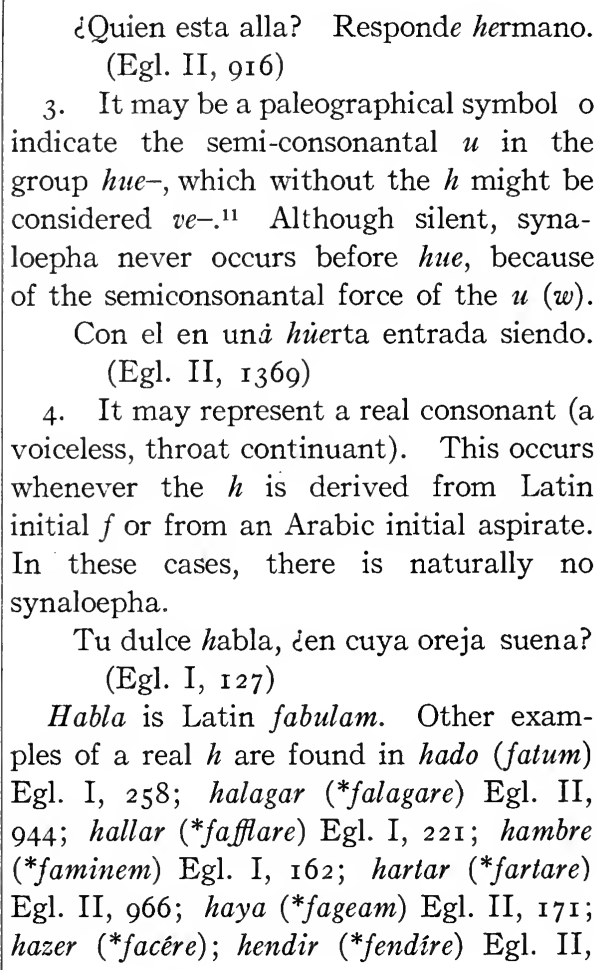 \\
\hline & H I S P N I C NOTES \\
\hline
\end{tabular}




\section{I F E A N D W O R K S}

I 497; hervir (fervire) Egl. II, 732; hierro (ferrum) Egl. II, I365; hijo (filium) Egl. II, I2I8; hilo (filum) Egl. III, I I2; hincar ( ${ }^{*}$ igicare?) Egl. III, I66; holgança (holgar $<$ follicare) El. I, 292; hondo (*fundum) Egl. II, 445; hurtar (*furtare) Egl. II, 892; huyr (*fugíre) Egl. II 765 ; hermoso (formosum) Egl. I, 3I7; herir (ferire) Egl. II, I5I; hasta (Arabic 'atta) Egl. II, I45. Of doubtful origin are hele (Egl. II, 78) and heme (Egl. II, 565), and the proper name Hortiga.

In the third Eclogue there are four apparent exceptions to the aspiration of this $h$, three in hermoso and one in herido. Estava figurada alli la hermosa. (line I 29)

De la su hermosa carne despidiendo. (line 136 )

Con su venablo en la mano que hermoso. (line ${ }_{17} 6$ )

Tras esto el puerco alli se vehia herido. (line I77)

There are certain other evidences that this Eclogue was left in an unfinished

\section{A N D MONOGRAPH S}




\begin{tabular}{|c|c|}
\hline 320 & GARCILASO DE LA VEGA \\
\hline & $\begin{array}{l}\text { state, such as the faulty rhymes in lines } \\
204,359 \text {, and } 374 \text {, as well as the imperfect } \\
\text { line ( } 374) \text { in the last octave. It is proba- } \\
\text { ble that the failure to aspirate the } h \text { in } \\
\text { these cases (elsewhere hermoso and herido } \\
\text { begin with a consonant) must be attributed } \\
\text { to the hand of Boscán, for in the works of } \\
\text { the latter there is evident a considerable } \\
\text { degree of uncertainty in the treatment of } \\
\text { words of this type, and in particular, } \\
\text { hermoso and herido are more often found } \\
\text { with a silent, than with an aspirate } h \text {. } \\
\text { That } h \text { was actually pronounced in the } \\
\text { Castilian of Garcilaso's time is clear from } \\
\text { a passage in the Dialogo de la lengua, in } \\
\text { which Valdés says: "Torno a dezir que } \\
\text { de la pronunciacion Arabiga le viene a la } \\
\text { Castellana en convertir a la } F \text { Latina en } H \text { : } \\
\text { de manera que, pues la pronunciacion es } \\
\text { con } H \text {, yo no se por que ha de ser la } \\
\text { escritura con } F \text {, siendo fuera de proposito } \\
\text { que en una lengua vulgar se pronuncie de } \\
\text { una manera y se escriva de otra." }{ }^{1} \text { It } \\
\text { would seem that Garcilaso was one of } \\
\text { those who favored the use of } f \text {, for a little }\end{array}$ \\
\hline & H I S A N IC NOTES \\
\hline
\end{tabular}




\section{LIFE AND WORKS}

later Valdés remarks: "Huelgome que os satisfaga; pero mas quisiera satisfazer a Garci-Lasso de la Vega con otros dos cavalleros de la Corte del Emperador que yo conozco." But in the letter which he sent to Seripando in 1536 , the autograph of which is preserved, he uses various forms of hazer always with an $h$ rather than an $f$. At least we may be sure that for a Castilian, like Valdés or Garcilaso, it would have been difficult to pronounce these words without the $h$, which is equivalent to saying that synaloepha would have been wholly unnatural, but for a Catalan, like Boscán, it would have been perfectly natural, since the Catalan language has at no time had an $h$ in its phonology. ${ }^{1}$

As further evidence of the lack of finish in the lines in question, it should be remarked that the use of the Old Spanish, or Italian form of the possessive adjective is found in only one other passage in Garcilaso, "la mi muerte" (Egl. II, 529) and there it is undoubtedly an imitation of the original of Sannazaro, "Voy,

\section{A N D MONOGRAPHS}




\begin{tabular}{|c|c|}
\hline 322 & GARCILASO DE LA VEGA \\
\hline & $\begin{array}{l}\text { Archadi, cantareti ney nostri monti la mia } \\
\text { morte" (Arcadia, Prosa VIII, 246-47), } \\
\text { which he is paraphrasing; that line I } 76 \text {, as } \\
\text { it appears in the text, with accents on the } \\
\text { fourth and seventh syllables has no count- } \\
\text { erpart in Eclogue III, and finally that the } \\
\text { form vehia is nowhere else used in Garcilaso } \\
\text { except in the rhyme. } \\
\text { Although it is the normal practice of } \\
\text { Garcilaso to pronounce in a single syllable } \\
\text { any two adjacent vowels in consecutive } \\
\text { words, there are certain cases in which he } \\
\text { permits hiatus. The conditions under } \\
\text { which this occurs are as follows: } \\
\text { I. When the word-stress of the second } \\
\text { vowel is reinforced by the line-stress. } \\
\text { En tanta confusion que nunc } \dot{a} \text { sso. } \\
\text { (Son. XII, } 7 \text {; other examples: Canc. } \\
\text { IV, } 49 \text {; El. I, } 7 \mathrm{I}, \text { I } 40 \text {;. Egl. I, } 237 \text {; } \\
\text { Egl. II, 408, 604, } 880,890, \text { I } 45^{2} \text {, I } 770 \text {; } \\
\text { Egl. III, 297) } \\
\text { Even in this position there are more } \\
\text { examples of synaloepha than of hiatus. So: } \\
\text { En fin que comoquiera esto yo de arte. } \\
\text { (Son. XVII, I } 2 \text {; other examples: }\end{array}$ \\
\hline & H I S A N I C NOTES \\
\hline
\end{tabular}




\section{LIFE A N D W O R K S}

Canc. I, 25; El. I, I3, 40; El. II, 45; Egl. I, 69, го6, I 22, 356; Egl. II, 393, 769, IOI 2, I 402; Egl. III, I 52, I 85 )

The tendency to avoid synaloepha before the main line-stress is evident already in Dante,

Dall'ampio loco ove tornar tí $\dot{a}$ rdi. (Inf. II, 84) ${ }^{1}$

and is also to be found in Boscán and the other poets of the Italian school in Spain. ${ }^{2}$ But Garcilaso himself in his letter to Seripando writes "d'aqui" and in the first edition of Barcelona readings such as "d'arte" (Son. XVII, I 2) are frequent. As far as it is possible to judge from the examples, it was Garcilaso's practice to elide two identical vowels ("sobre ellos"), and also proclitic monosyllables such as $d e, l e$, and $t e$; in other cases he preferred hiatus.

II. When the word stress of the second vowel is reinforced by a secondary linestress.

\section{A N D M O N O R A P H S}




\begin{tabular}{|c|c|}
\hline 324 & GARCILASO DE LA VEGA \\
\hline & $\begin{array}{l}\text { Escrito esta en mi alma vuestro gesto. } \\
\text { (Son. V, I; before alma also in Son. } \\
\text { XIX, 3; Canc. V, 70; El. I, 4I; } \\
\text { Egl. III, I3) } \\
\text { Mas inficion de ayre en solo un dia. } \\
\text { (Son. XVI, I 2) } \\
\text { Ven, si por solo ésto te detienes. (Egl. } \\
\text { I, 2 I 5) } \\
\text { Aunque pedir tii ésso no es cordura. } \\
\text { (Egl. II, 4I 3) } \\
\text { Nunca estable ni ina que llamava. } \\
\text { (Egl. II, I420) } \\
\text { Me parece que oygo que a la cruda. } \\
\text { (Egl. I, 376) } \\
\text { Garcilaso's usage in these cases, where } \\
\text { the word stress is reinforced, is analogous } \\
\text { to his regular practise of using diaeresis } \\
\text { in the same situation. } \\
\text { III. When an unstressed monosyllable } \\
\text { begins a line. } \\
\text { Mi alma os ha cortado a su medida. } \\
\text { (Son. V, Io; before alma also in } \\
\text { Egl. I, } 269 \text {; Egl. II, } 773 \text {; other } \\
\text { examples before stressed vowels: }\end{array}$ \\
\hline & H I P A N I N OTES \\
\hline
\end{tabular}




\section{I F E A N W O R K S}

Son. XIII, 5 ; Canc. I, 24 ; Canc. V, 84; Egl. II, I096, I340, I352, I358, I63I)

Que èn su dano os pide, yo querria.

(Son XIV, Io; another example before an unstressed syllable: Egl. II, 56 .

It will be noted that there are no less than eight of the examples quoted in the last two groups before the word alma; and it may be added that there is no case in which there is synaloepha before this word. ${ }^{1}$ The spellings ellagua ${ }^{2}$ and ellalma, so frequent in early Spanish texts, were undoubtedly phonetic and probably represented the pronunciation even in Garcilaso's time, for Francisco Robles in his Reglas de ortographia (I 533$)^{3}$ says, "Escribimos algunas veces $l$ sencilla e pronunciamosla doblada; como por decir la alma, la aguja, decimos ellalma, ellaguja." Possibly this use of the palatalized $l$ before alma and other words beginning with stressed $a$ may have given rise to a feeling that there was a semiconsonantal nature

\section{A N D MONOGRAPH S}




\begin{tabular}{|c|c|}
\hline 326 & GARCILASO DE LA VEGA \\
\hline & $\begin{array}{l}\text { in the beginning of these words which } \\
\text { made hiatus natural. For alma, it should } \\
\text { be remarked that one of the rare cases of } \\
\text { hiatus in Petrarch is in the line, } \\
\text { Che fai, } \dot{a} \text { lma? che pensi? avrem mai pace? } \\
\text { (Son. CXVII, I) } \\
\text { It is not incredible that so devoted a } \\
\text { follower of Petrarch as Garcilaso should } \\
\text { have imitated his master even in this tri- } \\
\text { fling detail. } \\
\text { Of the other examples of hiatus, only } \\
\text { one group seems to conform to a definite } \\
\text { principle, that after an inner rhyme. } \\
\text { Aquesta mano ayrad } \dot{a} \text {. Esta quedo. } \\
\text { (Egl. II, 992) } \\
\text { En quanto me deteng } \dot{a} \dot{a} \text { qui un poco. } \\
\text { (line I002) } \\
\text { Pues vete tu jornad } \dot{a} \dot{y} \text { no entiendas. } \\
\text { (line Ioo8) } \\
\text { ¿Que es esto, Nemoros } \dot{y} \dot{y} \text { que cosa? } \\
\text { (line II } 40 \text { ) } \\
\text { Con ligera corrid } \dot{a} \dot{y} \text { con ellas. (line } \\
\text { I } 286 \text { ) }\end{array}$ \\
\hline & H I P A N I C NOTES \\
\hline
\end{tabular}




\section{I F E A N D W O R S}

Estava embevecid $\dot{y}$ la diosa. (line I 373$)^{1}$

These cases, few in comparison with the one hundred and seventy cases in which there is synaloepha of the unstressed syllable of the inner rhyme and a following syllable, reveal that Garcilaso still had a vague feeling that the septenary and the quaternary formed individual units, and in a line such as the first cited above, that feeling was the more natural since the quaternary was spoken by a different person than the septenary. ${ }^{2}$

Analogous to this group are such cases as:

Lleno de vencimient $\dot{y}$ despojos. (Egl. I, 27 I)

iO quanto se acabo én solo un dia! (Son. XXVI, 3)

in which the hiatus occurs after the secondary stress.

The other cases of hiatus are sporadic:

Phaethon, si n $\dot{o}$, dqui veras mi muerte.

(El. I, 50)

$\mathrm{Y}$ se que $\dot{e}$ tramente me aprovecha. (Ep., 46)

\section{A N D MONOGRAPHS}




\begin{tabular}{|c|c|}
\hline 328 & GARCILASO DE LA VEGA \\
\hline & $\begin{array}{l}\text { Yendome } \dot{e} \text { lexando cada dia. (Son. } \\
\text { III, } 3)^{1} \\
\text { En su lugar li infelice avena. (Egl. I, } \\
\text { 30I). } \\
\text { One line, at least, shows a double hiatus: } \\
\text { Casi los passo y cuenti } \dot{u} \text { ino } \dot{a} \text { ino. } \\
\text { (Egl. I, } 362 \text { ) } \\
\text { illustrating two of the types we have dis- } \\
\text { cussed, that before the main line-stress } \\
\text { and that after the secondary line-stress. } \\
\text { The nine sonnets published by Francisco } \\
\text { Sánchez in I } 574 \text { and I577 conform to the } \\
\text { various practices already outlined in the } \\
\text { last sections, but as they were prepared } \\
\text { for publication by their learned editor at } \\
\text { a time when Garcilaso had already become } \\
\text { a model for Castilian sonneteers, their } \\
\text { testimony is of little value. }{ }^{2} \text { Even the } \\
\text { coplas in the native measures follow the } \\
\text { rules of prosody which we have found in } \\
\text { the verses in the Italian manner. Thus in } \\
\text { Hiziera no podia ser. (Copla IV, I } 3 \text { ) } \\
\text { we have the usual synaeresis of ia, and in } \\
\text { El pe-or de los Troyanos. (Copla V, } 5 \text { ) } \\
\text { there is diaeresis in the group } e-0 \text {. }\end{array}$ \\
\hline & H I P A N I N N T E S \\
\hline
\end{tabular}




\section{LIFE AND WORKS}

The study of Garcilaso's versification makes clear how closely he studied and followed his Italian models. But it also shows that his imitation was by no means slavish. When the genius of his own speech demanded a different practice, he did not hesitate to depart from his models. Above all it bears renewed testimony to his fine ear for musical effect and his excellent taste. He provided Spain with a fully perfected technique in this, the first experiment in the new form.

\section{d. METRICAL COMBINATIONS}

Boscán's explanation of the origin of his interest in the Italian forms of verse and his statement that it was Garcilaso who stimulated his failing enthusiasm by advice and example have always been taken as an evidence of his priority in the field of experiment in the Italian forms. There is, it is true, no reason for questioning the fact that it was Boscán, rather than Garcilaso, who wrote the first sonnets and canciones in Castilian in the sixteenth cen-

\section{A N D MONOG R P H S}




\begin{tabular}{|c|c|}
\hline 330 & GARCILASO DE LA VEGA \\
\hline & $\begin{array}{l}\text { tury. But concerning the other metrical } \\
\text { forms, in which unquestioned priority has } \\
\text { also been granted to the former, there is } \\
\text { much room for discussion. Let us examine } \\
\text { briefly the evidence in the matter. } \\
\text { Aside from the sonnet and canción, the } \\
\text { forms used by Boscán are: tercets, in his } \\
\text { capitulo and epistolas; blank verse, in his } \\
\text { Historia de Leandro y Hero; and octaves } \\
\text { in his Octava rima. Now all of these forms } \\
\text { are used by Garcilaso as well and there is } \\
\text { no reason why his experiments in these } \\
\text { forms may not be the first. The earliest } \\
\text { tercets of Garcilaso are those found in } \\
\text { Eclogue II, written probably in I } 533 \text {. } \\
\text { It is impossible to date the tercets of } \\
\text { Boscán; the only evidence available is at } \\
\text { best vague. The Epistola of Mendoza }{ }^{1} \\
\text { mentions Gutierre de Cetina among their } \\
\text { friends and since Gutierre de Cetina was } \\
\text { born about I } 520,{ }^{2} \text { it is incredible that } \\
\text { Mendoza's tercets could have been written } \\
\text { as early as I } 533 \text {; it is probable that they } \\
\text { belong nearer to I } 540 \text { and hence, Boscán's } \\
\text { Respuesta must be later than this date. }\end{array}$ \\
\hline & H I P A N I C N T T S \\
\hline
\end{tabular}




\section{LIFE A N D W ORK S}

At least, we may say that there is no evidence that Boscán's tercets are earlier than those of Garcilaso.

For the blank verse and the octaves the evidence is more definite. Garcilaso's only experiment in blank verse, the Epistola to Boscán, was written in October, I 534. The Historia de Leandro y Hero reveals a knowledge of the poem of the same name by Bernardo Tasso. But Tasso's work was first published in the 1537 edition of his Amori. It is at once clear that the versos sueltos of Garcilaso antedate those of Boscán by several years. And similar evidence is at hand for the octaves. Garcilaso's only use of the octava rima is found in Eclogue III, written in the year of his death. But those of Boscán were certainly written after the death of the former, for in his eulogies of the famous poets of Castile, he refers to him always in the past,

$\mathrm{Y}$ aquel que nuestro tiempo traxo ufano,

el nuestro Garcilasso de la Vega ... que del amor acrecento el estado. ${ }^{1}$

\section{A N D MONOGRAPH S}




\begin{tabular}{|c|c|}
\hline 332 & GARCILASO DE LA VEGA \\
\hline & $\begin{array}{l}\text { while he refers to the living poet Guálvez } \\
\text { always in the present. Garcilaso's priority } \\
\text { in the use of the octave and the blank verse } \\
\text { is therefore established, and to these forms } \\
\text { should be added his use of the inner rhyme } \\
\text { and, of more permanent importance, the } \\
\text { ode form which from his one example has } \\
\text { received its name, the lira. There is no } \\
\text { excuse for an effort to diminish the fame } \\
\text { of Boscán as a pioneer, but there is likewise } \\
\text { no excuse for striving to lend him an un- } \\
\text { warranted credit for a service which he did } \\
\text { not perform. It is sufficient to have } \\
\text { demonstrated that Garcilaso shares with } \\
\text { his friend the glory of initiating his people } \\
\text { in the Italian forms. } \\
\text { The metrical combinations of Garcilaso, } \\
\text { like the other details of his technique, are } \\
\text { derived from the Italian masters. As } \\
\text { might be expected, in his Canzoniere his } \\
\text { master is Petrarch. In the sonnets, the } \\
\text { quatrains are rhymed without exception: } \\
\text { ABBA: ABBA. In the tercets the three } \\
\text { common rhyme-schemes are Petrarchan: }\end{array}$ \\
\hline & H I P A N I C NOTES \\
\hline
\end{tabular}




\section{LIFE A N D WORKS}

CDECDE: Son. II-IX, XIII, XVII, XX, XXIV.

CDEDCE: Son. I, XVIII-XIX, XXI, XXIII, XXIX, (XXX-XXXI, XXXIV-XXXV).

CDCDCD: Son. X-XI, XIV, XXVII, (XXXVII).

The other forms are:

CDEDEC: Son. XV, XXVI, (XXXVI). Used once by Petrarch (Son. LXXIV). and also by Sannazaro, Ariosto and Bembo.

CDECED: Son. XII, XVI. Used by Sannazaro, Ariosto and Bembo.

CDEECD: (Son. XXXII). Used frequently by Ariosto.

The unity of the quatrains and tercets is maintained with great scrupulousness, and in only two cases (Sons. XVI and XVIII) do the quatrains run over into the tercets.

The first four canciones are also Petrarchan:

Canción I: ABCBAC:c DdEeFF. Envoy: $\mathrm{xYyZzWW}$. (Petrarch, XX)

\section{A N D MONOGRAPHS}




\begin{tabular}{|c|c|}
\hline 334 & GARCILASO DE LA VEGA \\
\hline & $\begin{array}{l}\text { Canción II: abCabC:cdeEDfF. } \\
\text { Envoy: XyY: This is the form of } \\
\text { Petrarch's Canzone XIV, with the } \\
\text { substitution of a hendecasyllable } \\
\text { for the septenary in the tenth line. } \\
\text { It is noteworthy that the sister } \\
\text { canzone in Petrarch (XIII) shows a } \\
\text { variation: abCabC:cdeeDff. } \\
\text { Canción III: abCabC:cdeeDfF. En- } \\
\text { voy: xyZxyZwW. Petrarch, XIV, } \\
\text { but the envoy is not that of Pe- } \\
\text { trarch (XyY). Stanza } 5 \text { (lines } 52-65 \text { ) } \\
\text { has a nine-syllable line instead of } \\
\text { a hendecasyllable in the eleventhline. } \\
\text { Canción IV: ABCBAC:CDEe:FGH- } \\
\text { HGFFII. Envoy: YWXXWYY- } \\
\text { ZZ. (Petrarch, I) } \\
\text { Canción V is intitled an Ode, and its } \\
\text { form is taken from Bernardo Tasso. The } \\
\text { rhyme-scheme is: aBabB, without envoy. } \\
\text { The first example of the use of this particu- } \\
\text { lar ode-form by Tasso is found in the } \\
\text { second edition of his Amori (I } 534 \text { ), in the } \\
\text { ode "O pastori felici." (f. } 87 \mathrm{r}^{\circ} \text { ) } \\
\text { For the longer compositions of Garcilaso }\end{array}$ \\
\hline & H I P A N I N N T E S \\
\hline
\end{tabular}




\section{LIFE A N D WORKS}

we shall have to seek his immediate models elsewhere than in Petrarch.

Elegies I and II are in tercets, beginning: $\mathrm{ABA}: \mathrm{BCB}: \mathrm{CDC}$ :etc., and ending: $\mathrm{XYX}: \mathrm{YZYZ}$. It is not necessary to trace here the origin of the tersa rima in Italy nor its varied uses. But the question of the use of this title to describe a composition in tercets is more involved and needs an explanation. The Italian writers of the late fifteenth and early sixteenth centuries had regularly used the terms "capitoli" or "epistole" for poems of this sort in tercets and these are the titles used by Boscán. The first poet, so far as I am aware, to employ the term "elegia" for a poem in tercets which was not actually elegaic, was Luigi Alamanni, who included a number of "elegie" in the edition of his verses of $\mathrm{I}_{532}$. It is possible that Garcilaso knew the work of Alamanni, but it is more probable that he received the suggestion for the use of the term from Bernardo Tasso's use of the word in the second edition of his Amori, already

\section{A N D MONOG R P H S}




\begin{tabular}{|c|c|}
\hline 336 & GARCILASO DE LA VEGA \\
\hline & $\begin{array}{l}\text { referred to, where he printed six "Elegie". } \\
\text { That Garcilaso was acquainted with the } \\
\text { work of Tasso there can be no doubt and } \\
\text { his first Elegy shows an actual imitation of } \\
\text { one of Tasso's elegies. } \\
\text { The Epistle to Boscán is in blank verse } \\
\text { and the source of the form is not obvious. } \\
\text { Although evidences of its early appearance } \\
\text { in Italy are not lacking, the form never } \\
\text { obtained any foothold in Italian until the } \\
\text { beginning of the sixteenth century when } \\
\text { it was employed by Trissino with the } \\
\text { conscious purpose of reproducing Latin } \\
\text { verse effects in his tragedy, Sofonisba, } \\
\text { written in I } 5 \text { and first printed at Rome } \\
\text { in I } 524 \text { Almost contemporary with this } \\
\text { is the Rosmunda of Rucellai, published in } \\
\text { I } 525 \text { There followed other tragedies in } \\
\text { the same metre such as La Tullia of } \\
\text { Martelli or the Antigone of Alamanni, } \\
\text { both of I533. But these dramatic works, } \\
\text { though they may have been known to } \\
\text { Garcilaso, could hardly have suggested to } \\
\text { him the possibilities of the blank verse for } \\
\text { other forms of composition. Aside from }\end{array}$ \\
\hline & H I P A N I NOTES \\
\hline
\end{tabular}




\section{I F E A N D W O R K}

them, only one other work containing poems in blank verse was printed before his death, the Opere toscane of Alamanni, printed at Lyons in $\mathrm{I} 532$ and $\mathrm{I}_{533}{ }^{1}$ These two volumes contain in blank verse, besides the Antigone, fourteen Egloghe, Il diluvio romano, Favola di Athlante, three books of Selve, and the Favola di Phetonte. Passing over the longer narrative poems, which soon had their imitators in the Leandro $e$ Ero of Bernardo Tasso and through him, in the work of Boscán, it may well be that the egloghe and selve gave to the Spanish poet the idea of using blank verse for the purpose of a short composition in the lyric vein. It will be remembered that the Epístola in question was dated from Avignon; it is not beyond the bounds of possibility that Garcilaso saw the works of Alamanni there for the first time and immediately proceeded to try the metre. His experiment is brief and reveals no mastery of the form.

The first Eclogue is composed of thirty stanzas:

\section{A ND MONOGRAPHS}




\begin{tabular}{|c|c|}
\hline 338 & GARCILASO DE LA VEGA \\
\hline & 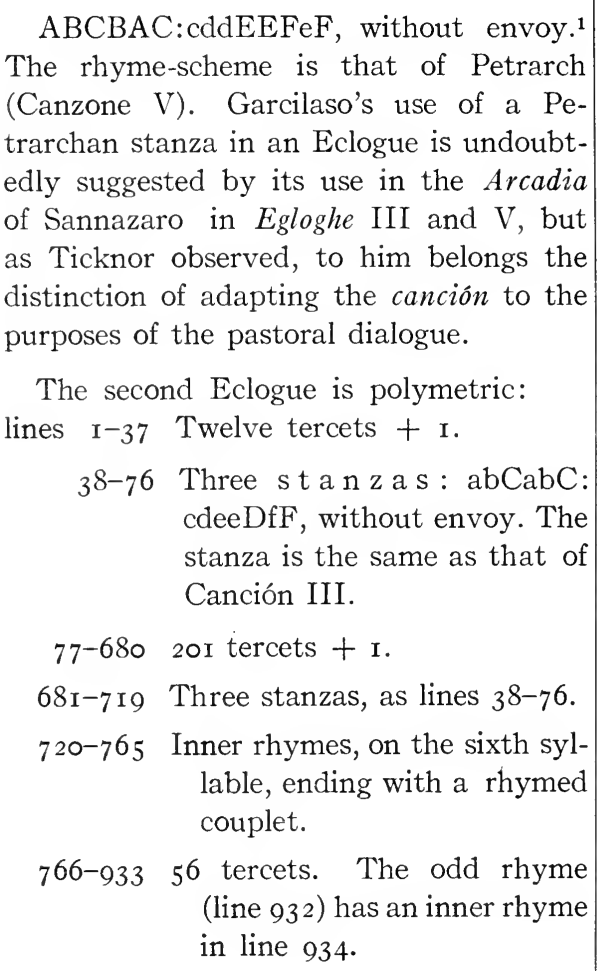 \\
\hline & H I S A N I C NOTES \\
\hline
\end{tabular}




\section{LIFE A N D W OR S}

934-103I Inner rhymes. The last line has an inner rhyme in line I032.

1032-II 2832 tercets + I.

II 29-I 828 Inner rhymes. The last line has an inner rhyme on the third syllable of line 1829 .

I829-I854 Two stanzas: abCbaC: cdee $\mathrm{DfF}$, equivalent to the stanzas already used, but with the fourth and fifth rhymes reversed.

I $855-1885$ Ten tercets $+\mathrm{I}$.

Of the complicated history of the polymetric eclogue in Italy I have treated in another place. ${ }^{1}$ For the present it is enough to say that the two chief sources for Garcilaso in his use of the form were Sannazaro and Tansillo. To the former he owes not only the suggestion of the type, offered in the first, second and tenth Egloghe of the Arcadia, but also numerous details of execution. Thus, his practise of beginning a series of inner rhymes with a

\section{A N D MONOGRAPHS}




\begin{tabular}{|c|c|}
\hline 340 & GARCILASO DE LA VEGA \\
\hline & $\begin{array}{l}\text { hendecasyllable rather than a septenary } \\
\text { could have come only from the Arcadia } \\
\text { (Egloga X); similarly his failure to break } \\
\text { the series of inner rhyme lines into tirades } \\
\text { by the occasional introduction of a septen- } \\
\text { ary, and his method of concatenation of } \\
\text { tercets and inner rhymes (lines 932-934) } \\
\text { and of inner rhymes and tercets (lines } \\
\text { I03I-32) or inner rhymes and stanzas } \\
\text { (lines I } 828-29 \text { ) are copied directly from } \\
\text { Sannazaro's Egloga X. Nor is it mere } \\
\text { coincidence that the stanza form which he } \\
\text { employs in two instances, is precisely that } \\
\text { used in Egloga V of the Arcadia. }{ }^{1} \text { Gar- } \\
\text { cilaso's obligation to Tansillo is less spe- } \\
\text { cific. If he had any opportunity to study } \\
\text { in detail I due pellegrini, it must have been } \\
\text { in manuscript; perhaps he knew it only } \\
\text { from some unrecorded representation at } \\
\text { the Court of the Viceroy of Naples. His } \\
\text { imitation of Tansillo, then, seems to be } \\
\text { limited to questions of general principle, } \\
\text { such as the use of canzone stanzas in a poly- } \\
\text { metric composition or the use of inner } \\
\text { rhyme lines for ordinary narrative, for in }\end{array}$ \\
\hline & H I S P N I C NOTES \\
\hline
\end{tabular}




\section{LIFE A N D WORKS}

Sannazaro and the other Neapolitan poets they are normally used for the expression of nonsense verses or "dark sayings." It should be remarked, however, that both Epicuro and Tansillo had used freely rhymed stanzas, a sort of silia, in their pastorals, rather than the fixed Petrarchan stanzas, and the adoption of this form in his Eclogue is Garcilaso's real contribution to the structure of the polymetric eclogue.

The third Eclogue is in octaves. There can be no doubt that their use in this eclogue, which is mythological and allegorical, rather than purely pastoral, is an imitation of the Tirsi of Baldassare Castiglione and Cesare di Gonzaga, recited before the Duke and Duchess of Urbino in 1506. In Italy the ottara rima is rare in the lyrical eclogues, although common in the dramatic eclogues and mythological poemetti. The only example in a pastoral poem before the time of Garcilaso, outside of the poem of Castiglione, is found in the Opere volgari (1532) of the little known poet Luca Valentiano. ${ }^{3}$

\section{A N D MONOGRAPHS}




\begin{tabular}{|c|c|}
\hline 342 & GARCILASO DE LA VEGA \\
\hline & $\begin{array}{l}\text { It remains to speak a word concerning } \\
\text { the rhymes in Garcilaso's verses in the } \\
\text { Italian style. They are almost without } \\
\text { exception paroxytone (llanas). In this con- } \\
\text { nection it is interesting to find that two } \\
\text { final unstressed vowels count as a single } \\
\text { syllable. Thus we have rhymes in -acia, } \\
\text {-ancia, -ario, -ecio, -edio, -encia, -eria, } \\
\text { - erio, -icia, -icio, -izio, -ocio, -oria, and } \\
\text {-uria counting as normal penultimate } \\
\text { rhymes. This practise, thoroughly in con- } \\
\text { formity with Castilian pronunciation, } \\
\text { marks one of the fundamental differences } \\
\text { between Spanish and Italian versification. } \\
\text { With this principle once established, the } \\
\text { number of proparoxytone words, aside } \\
\text { from verb forms, remaining in Castilian } \\
\text { was relatively small and esdrújulas never } \\
\text { gained a foothold in Spain. There is in } \\
\text { Garcilaso but one example of a true } \\
\text { esdrújula rhyme, in the imperfect ending } \\
\text {-avamos (Egl. II, 2Io-2I } 4 \text { ); but it shows } \\
\text { the unhappy monotony of such a verbal } \\
\text { rhyme and Garcilaso nowhere else at- } \\
\text { tempted it.1 }\end{array}$ \\
\hline & H I PANIC NOTES \\
\hline
\end{tabular}




\section{I F E A N D W O R K S}

There are also a few examples of oxytone rhymes (agudas) in the canciones and two cases in the sonnets. In Canción I there is an unrhymed line in the envoy, ending in ver; in Canción II, there are rhymes in -ar, $-a d,-o r,-i$, and -é; and in Canción III, there are rhymes in -er and -ar. It is probable that the use of rimas agudas was considered justified in a canción because of Petrarch's use of an oxytone rhyme in his Canzone XI. But there are also rimas agudas in two of Garcilaso's sonnets, XXVII and XXXII, in $-i$ and $-a l$. There has been much discussion of the desirability of using these rhymes in Castilian verse, the principal justification being naturally the large number of oxytone words in the language. They are not unknown in Italian, for Dante has fourteen examples and Ariosto two in the Orlando furioso. In Spain they are very common in Boscán and Diego de Mendoza in their verses in the Italian measures. It should be observed, however, that the authenticity of both of the son-

\section{A N D MONOGRAPHS}




\begin{tabular}{|c|c|}
\hline 344 & GARCILASO DE LA VEGA \\
\hline & $\begin{array}{l}\text { nets of Garcilaso in which they occur has } \\
\text { been questioned, largely because of them, } \\
\text { and the general absence of such rhymes } \\
\text { in the Spanish sonnets and other Italian } \\
\text { forms in the poets of the Golden Age may } \\
\text { be attributed to Garcilaso's example. } \\
\text { Aside from obvious printer's errors, } \\
\text { there are a number of faulty rhymes in } \\
\text { Garcilaso. Three of these are found in } \\
\text { Eclogue III (lines 204, 359, and 374) and } \\
\text { are doubtless an evidence of the unfinished } \\
\text { state in which the poet left this last poem. } \\
\text { The others occur in the inner rhymes in } \\
\text { Eclogue II: cabo-hago (lines Ioo6-7), } \\
\text { culebras-negras (lines } 944-45 \text { ), puedes-deves } \\
\text { (lines 997-98), Phaunos-Silvanos (lines } \\
\text { I I } 56-57 \text { ) sangre-hambre (lines I } 205-6 \text { ), } \\
\text { sangre-estambre (lines I } 242-43 \text { ), sangre- } \\
\text { hambre (lines I663-64), campo-blanco (lines } \\
\text { I } 257-58 \text { ). Although there is no possibility } \\
\text { that these could have formed perfect } \\
\text { rhymes to Garcilaso, it should be remem- } \\
\text { bered that in Garcilaso's time there were } \\
\text { some, like the good Castilian Juan de } \\
\text { Valdés, who always pronounced the nasal }\end{array}$ \\
\hline & H I PANIC NOTES \\
\hline
\end{tabular}




\section{I F E A N D W O R K S}

$n$ rather than $m$ before $p$ and $b$, which would reduce most of the examples to a simple dissonance between $b$ and $g, d$ and $v$, or $p$ and $c$. Furthermore, there is assonance in every case and the pairs are either both voiced or both voiceless. In the case of Phaunos, it should possibly be pronounced Fanos, as some of the editions have it. Perhaps it is unnecessary to say more than that they are evidences of haste or carelessness, some of them involving difficult rhymes.

Equivocal rhymes are not infrequent in Garcilaso's verse but their use never degenerates into abuse. ${ }^{1}$ Occasionally the same word seems to be employed without distinction of meaning, as in

El veloz movimiento parecia que pintado se via ante los ojos.

Con amorosos ojos adelante Carlo, Cesar triumphante, le abraçava.

(Egl. II, 1500-3)

Regularly, however, the identical forms

\section{A N D MONOGRAPHS}




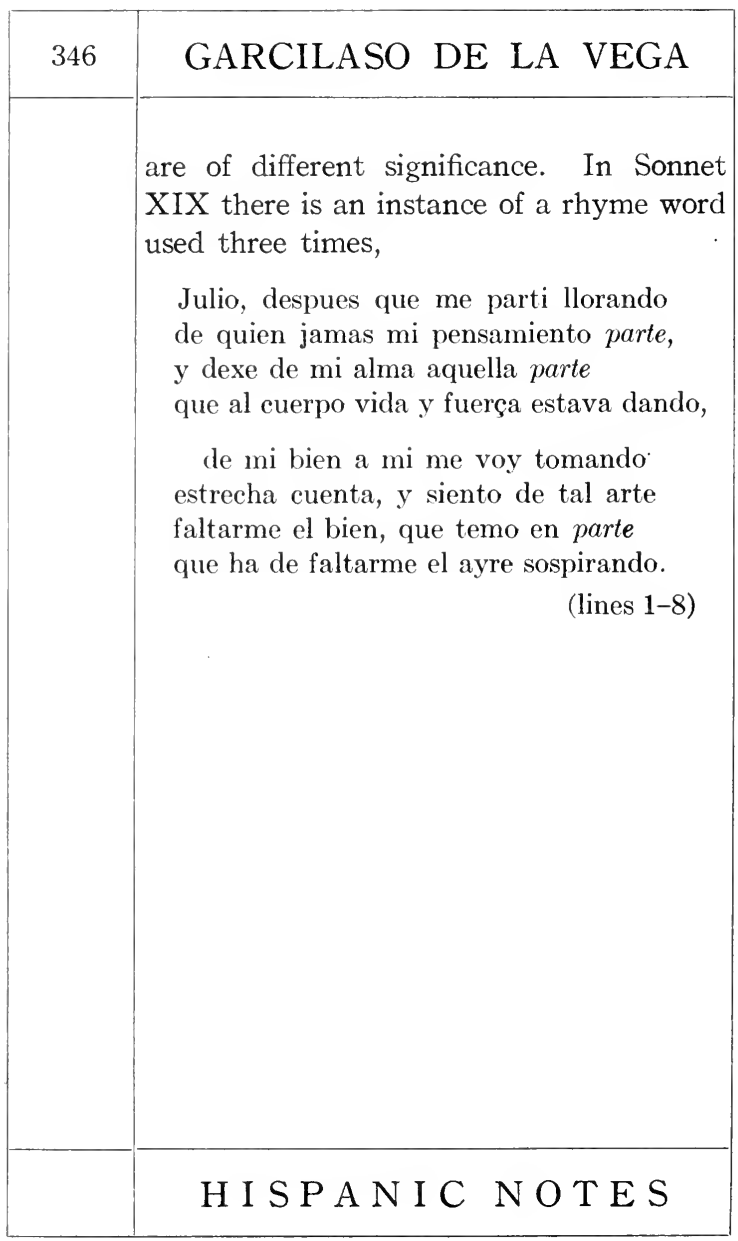




\section{I F E A N W W R K S}

\section{CHAPTER V}

ORTHOGRAPHY, VOCABULARY

\section{AND GRAMMAR}

\section{a. ORTHOGRAPHY}

The conditions under which the poems of Garcilaso were published, to which we have so often referred, make it impossible to draw any conclusions as to his personal orthography. But the text adopted, following the readings of the edition of Antwerp of I 544 in respect to spelling, stands at least as an example of the current orthography in the decade after his death. In general, it presents no striking peculiarities; the spellings are those which we find in other contemporary editions.

A few of these spellings are merely conventional and point to no divergence from the modern pronunciation. $Y$ for $i$ enjoys a rather frequent usage, being regularly employed in the diphthongs $a y, e y, o y$ and

\section{A N D M O N O R A P H S}




\begin{tabular}{|c|c|}
\hline 348 & GARCILASO DE LA VEGA \\
\hline & $\begin{array}{l}\text { uy, (ayre, deleyte, oygo, cuydado), and often } \\
\text { when the } y \text { is stressed, as creyble or ruydo. } \\
\text { Yedra, yelo, and yerva are the regular forms } \\
\text { and } y \text { is also used for initial } i \text { in such words } \\
\text { as yva, yre, ygual, etc. B and } v \text { are not } \\
\text { always employed as in modern Spanish; } b \\
\text { is more often used for the initial, as bozes, } \\
\text { buclto, etc., v in the interior of the word, as } \\
\text { escrivir, aver, etc. After } n \text { we find } r r \text { as in } \\
\text { cnrredar, honrra, and Enrriquez. Initial } h \\
\text { is often omitted when it represents a } \\
\text { Latin } h \text { or g: istoria, onesto, elado. } \\
\text { Another group of words, the spelling of } \\
\text { which differs from the modern spelling, } \\
\text { although the pronunciation was not dif- } \\
\text { ferent, consists of words derived from } \\
\text { Greek. Thus we find ll for } l \text {, ph for } f, \text { ch } \\
\text { for } c \text { or qu, th for } t \text {, not merely in proper } \\
\text { names such as Achilles, Anchises, Apelles, } \\
\text { Apollo, Daphne, Parthenope, Phaeton } \\
\text { Phebo, Philomena, Phillodoce, Phyllis and } \\
\text { Zephyro, but also in other words, such as } \\
\text { choro, cithera, limpha, machina, mirtho, } \\
\text { nympha, phantasma, phauno, philosopho, } \\
\text { thesoro, triumphante, tropheo. From other }\end{array}$ \\
\hline & H I P A N I N N T E S \\
\hline
\end{tabular}




\section{LIFE A N D W ORKS}

languages, we have Latinisms, like illustre, or Lampetia, and the use of qua- for modern cua- and double letters, particularly $f f$, as in affeto, ${ }^{1}$ deffender, etc; from Italian come spellings such as colunna, Ecco and ginette. Charo for caro ("dear") is doubtless due to the frequent use of this form in Italian writers of the period.

More important are the spellings which represent the pronunciation of the sixteenth century. The voiced and voiceless sibilants are constantly differentiated; $s s$, $\zeta$ and $x$, standing for the voiceless forms, (passo, caça, dexar), and $s, z$ and $j$ (ge, gi) for the voiced (glorioso, hazer, ultraje). There is, however, some uncertainty in the use of ss and $s$; apressura, atravessar, pessado and pressuroso are also found with a single $s$; asiento is regularly written with $s$, but assentado with $s s$.

The edition of Barcelona shows a number of older spellings, such as a sseguir, a rromper a rrazonar, and levantasse (for levanta-se). Beltad, drecho, and ninyes reveal the Catalan origin of the text.

\section{A N D MONOGRAPHS}




\begin{tabular}{|c|c|}
\hline 350 & GARCILASO DE LA VEGA \\
\hline & $\begin{array}{l}\text { b. VOCABULARY } \\
\text { Modern Spanish critics have universally } \\
\text { commented on the purity of Garcilaso's } \\
\text { language, remarking that there is hardly a } \\
\text { locution to be found on his works which is } \\
\text { not good usage in the speech of the pre- } \\
\text { sent. It is true, that if one compares his } \\
\text { works with those of his contemporaries, } \\
\text { Boscán or Diego de Mendoza, one is at } \\
\text { once struck by the fact that they are speak- } \\
\text { ing a language which is antiquated, while } \\
\text { Garcilaso sings a song of eternal youth. } \\
\text { Part of this is due to the limited field of } \\
\text { courtly expression in which he moves; } \\
\text { part too, to the fact that the constant imi- } \\
\text { tation of Garcilaso has served to keep } \\
\text { alive his vocabulary. But even in his } \\
\text { limited field there is a considerable number } \\
\text { of words and phrases which have since his } \\
\text { time become antiquated, almost all of } \\
\text { them current expressions in his time, which } \\
\text { prove that Garcilaso was merely employing } \\
\text { his native Castilian as any other gentleman } \\
\text { of his time. }\end{array}$ \\
\hline & H I S P N I C NOTES \\
\hline
\end{tabular}




\section{I F A N D W O R K}

First of all, there is a long list o: words which show a form or pronunciation different from the modern form: aderino. *acidente, *agora, aguelos, aparencia, *antigo, *ansi, *asconder, *ajuntamiento, añudar, Bernaldino, cativo, *oluna, contradicion, cobrio, comigo, comover, conortar, contino, costreñida, *condolesca, *conosco, cubijar, destruicion, decendido diciplinable, *desmamparada, esterelidad, escodriñar, *amberescido, elecion, *entramos (=entrambos), *enxemplo, escuro, especia (=especie). espedir, esperiencia, esprimir, estender, essecutar, Faderique, imenso, *imortal, jazen, lustre (=lustro) manifico. *mesclar, *nasci, nudo, redemido, *roydo, sentible, *sinificar, serena (=sirena), sospiro, sotil, supito. All of these words are current in early Spanish. It is interesting to note that, in the case of many of these words, the modern form as well appears in our text (these I have marked with an asterisk), a circumstance which points to the uncertainty already prevailing in their use. This uncertainty is especially common in the use of $e, i$, and

\section{A N D MONOGRAPH S}




\begin{tabular}{|c|c|}
\hline 352 & GARCILASO DE LA VEGA \\
\hline & $\begin{array}{l}\text { ie, where we find arteficio, deputar, dispedir } \\
\text { (and other forms with the prefix dis-), } \\
\text { empedir, enclinar, manifesto, medecina, etc., } \\
\text { in addition to the words already listed, } \\
\text { beside the common modern forms. In } \\
\text { learned words derived from Latin forms } \\
\text { containing -ct-, the use of perfeto in rhyme } \\
\text { makes it certain that the pronunciation } \\
\text { was with -t- and this is the common spell- } \\
\text { ing. But -ct- is found in affecto, perfecto, } \\
\text { respecto, subjecto, Octubre and victoria. } \\
\text { Not only does Garcilaso use a number } \\
\text { of words in an antiquated form but also } \\
\text { certain words which have quite dissap- } \\
\text { peared from modern speech, such as } \\
\text { amostrar, aquesso, aquesto, a baldia, cabe, } \\
\text { de consuno, corajoso, a desora, pensoso, } \\
\text { ruinar, superno, tristura and turar. }{ }^{1} \text { Others } \\
\text { which have survived, he employs in their } \\
\text { older meaning, which has now fallen into } \\
\text { disuse: alimana ( =animal), amancillar } \\
\text { (=entristecer), natura (=naturaleza), oreja } \\
\text { (=oido), recordar (=despertar), sobrar } \\
\text { (=sobrepujar), tirar (=quitar), trastornar } \\
\text { (=transponer), ves aqui (= he aqui or }\end{array}$ \\
\hline & H I P A N I C NOTES \\
\hline
\end{tabular}




\section{IFE A N D W ORK S}

aqui tienes). Forms which have survived only in popular speech are diz and engarrafarse. Finally there are a few words which either in form or meaning seem to be unique in Garcilaso: altercar for alternar (unless this be a misprint), degollar for desangrar (although El Brocense calls this reading "aquella bestialidad"), inocente for libre, pertrecho for pertrechos, poner for deponer. Desbañar (for aliviar) is found in at least one other passage in the works of Boscán.

Garcilaso's long residence in Italy and his intimacy with Italian men of letters is also clearly reflected in his rocabulary. Some of his words are frankly Italian: abastanca, caler (=bajar), carta (= papel), coruscar, cosa (= ¿qué?), domestiqueza, dubio $(=d u d a)$, estampa, estança, estrecheza, nojoso, pero ( =sin embargo), saliatiquesa, viso $(=$ cara $)$. Quite as clear an evidence is to be found in his tendency to choose, of two equivalent expressions, the one identical with the Italian, for example: avezar (Ital. averzzare) rather than acos-

\section{A N D M O N O R A P H S}




\begin{tabular}{|c|c|}
\hline 354 & GARCILASO DE LA VEGA \\
\hline & $\begin{array}{l}\text { tumbrar, de modo que (Ital. di modo che) } \\
\text { for de manera que, delgadeza and other } \\
\text { abstract nouns in -eza (Ital. -ezza) rather } \\
\text { than the forms in -ez or the older forms in } \\
\text {-ura; felice, infelice, veloce, for feliz, infeliz, } \\
\text { veloz; en torno (Ital. intorno) for al rededor } \\
\text { or al derredor, propio como yo for lo mismo } \\
\text { que yo. } \\
\text { The only examples of French words in } \\
\text { Garcilaso are two conscious Gallicisms in } \\
\text { the Epistola to Boscán: argen and varlete. } \\
\text { The second Eclogue differs radically in } \\
\text { its language from the other works of Gar- } \\
\text { cilaso and in its dramatic dialogue are pre- } \\
\text { served a number of expressions taken from } \\
\text { popular speech, many of which still sur- } \\
\text { vive. As instances we may cite: "No } \\
\text { daria ... solo un cornado"; "Callar que } \\
\text { callaras"; "Tener al pie del palo"; "Por } \\
\text { el passo en que me ves"; "Ya caygo en } \\
\text { ello"; "Vete tu jornada"; "Entre dientes } \\
\text { murmurando"; "acrecentar... un dedo"; } \\
\text { "Por tu vida"; "Una gran pieça" (of time); } \\
\text { "Boca arriba". These are expressions } \\
\text { which savor more of the pasos of Lope de }\end{array}$ \\
\hline & H I P A N I N N T E S \\
\hline
\end{tabular}




\section{I FE A N D WORK S}

Rueda than of the courtier of Charles $V$. And elsewhere in his works, we find vigorous phrases taken from the lips of the people: "Pues soy por los cabellos arrastrado"; "Salio al camino"; "Da consigo en el suelo"; "Cargo la mano tanto"; "No es mucho que ..." ; "Se fue su passo."

The second Eclogue also contains several reminiscences of popular refranes. "De bien acuchillado a ser maestro" recalls "No hay mejor cirujano que el bien acuchillado"; "Quan facilmente... el sano da consejos al doliente", "El sano al doliente so regla lo mete." So too such a phrase as, "Assi de un mal ageno, bien se empieça" has in it an echo of the proverb "No hay mal sin bien, cata para quien" and "De un dolor otro se empieça" is another was of saying, "Bien vengas mal, si vienes solo." Other lines as well have a sententious character, for example. "El mal comunicando, se mejora" or "A quien no espera bien, no ay mal que dañe."

\section{A. ND MONOGRAPHS}




\begin{tabular}{|c|c|}
\hline 356 & GARCILASO DE LA VEGA \\
\hline & $\begin{array}{l}\text { C. GRAMMAR } \\
\text { The grammar of Garcilaso, like his } \\
\text { orthography and his vocabulary, offers few } \\
\text { peculiarities and such as occur are for the } \\
\text { most part common to the speech and } \\
\text { literature of his time. } \\
\text { NOUNS. Color, with one exception, is } \\
\text { feminine, following the earlier Spanish } \\
\text { usage for abstract nouns in -or. Calor, } \\
\text { though regularly masculine, like the other } \\
\text { nouns in -or (rigor, dolor, etc.), is found } \\
\text { once as a feminine. } \\
\text { PRONOUNS. In general our text pre- } \\
\text { sents le as the direct object masculine of } \\
\text { the third person, but there is one instance of } \\
\text { lo in rhyme (escogiolo, Egl. III, 358). The } \\
\text { various editors have printed these forms } \\
\text { according to their individual preference. } \\
\text { In general the editions of Antwerp, I } 556 \\
(D) \text { and of Herrera ( } H \text { ) are the only ones } \\
\text { which are consistently loistas. } \\
\text { The use of the article for the possessive } \\
\text { in the line } \\
\text { Hasta moriros a los pies tendido, } \\
\text { (Canc. I, 13) }\end{array}$ \\
\hline & H I S P N I C NOTES \\
\hline
\end{tabular}




\section{I F E A N D W O R K S}

is perhaps strained, but does not seem to call for the usual emendation.

There are two cases of the Old Spanish form of the possessive adjective, "la $\mathrm{mi}$ muerte" (Egl. II, 529) and "la su hermosa carne" (Egl. III, I36). The first is perhaps, as we have remarked, an imitation of the Italian from which it is translated; the second is a doubtful passage.

The interrogative "¿cuyo?" is in one case used as an adjective, "¿en cuya oreja" (Egl. I, I27), a use sanctioned in Old Spanish but no longer practised.

The pronoun cual is twice used adverbially for como, once in an exclamation, “QQual me tienes la mano!" (Egl. II, 848), once as correlative to tan,

Con un tan eficaz remedio cura, qual se conviene a tristes amadores.

(Egl. II, 1090-91)

No nada occurs once, revealing the original affirmative force of natam.

The relative quien is used for things as well as persons, and even as a plural.

\section{A N D M O N G R A P H S}




\begin{tabular}{|c|c|}
\hline 358 & GARCILASO DE LA VEGA \\
\hline & $\begin{array}{l}\text { ARTICLES. The form el (originally } \\
\text { ela) is used before feminine nouns beginning } \\
\text { with } a \text {, even when the } a \text { is unstressed: el } \\
\text { arena, el amistad, etc. There is one in- } \\
\text { stance of el before a noun beginning with } \\
e \text { : el esperança (Canc. IV, 9o). } \\
\text { Similarly we find the form un before } \\
\text { agua, alma and ora. This is evidently a } \\
\text { case of elision. } \\
\text { AD JECTIVES. The use of adjectives } \\
\text { for adverbs is fairly common, so fuerte, } \\
\text { cierto, claro, pura y amorosa (Egl. III, 3og), } \\
\text { etc. } \\
\text { ADVERBS. A aquellas oras (entonces) } \\
\text { and a la ora (en seguida) are forms of earlier } \\
\text { Spanish. Primero que occurs for antes que; } \\
\text { possibly this is due to Italian influence. } \\
\text { VERBS. The verb forms offer more } \\
\text { peculiarities than the other parts of speech, } \\
\text { the number of old forms being not incon- } \\
\text { siderable. } \\
\text { In the inflectional endings there are } \\
\text { some survivals of the earlier usages in the } \\
\text { second person plural; showing the reten- } \\
\text { tion of the } d \text {, as aviades (Son. X, } 7 \text { ) or }\end{array}$ \\
\hline & H I P A N I NOTES \\
\hline
\end{tabular}




\section{IF E A N D W O R K S}

fuessedes (Canc. I, 9); the syncopation of the penult vowel, in pudierdes (Ep., 82); and the forms without the insertion of the analogical $i$, as llevastes, etc. (Son. X, 9). The forms dexaresme and mataresme (Egl. II, IoI 5-I6) may be derived directly from the termination -etis (>edes>ees>es) or be due to analogy with the syncopated future subjunctive or with the older preterite forms. ${ }^{1}$

Present Indicative. Old forms are esto (4 examples), conosco (Egl. II, 99, 3I9), vee (4 examples), afierra (Egl. II, Iого) and atierra (in the figurative sense, Egl. II, ro70). Atierra is also found in the literal sense (Egl. III, 332).

Present Subjunctive. The forms adolesca and condolesca occur in the rhyme (Egl. II, 353-54), but the forms in $-z c a$ are the regular use. In Egl. II, 9I 7 there is an example of the older subjunctive of valer in "Valasme, Dios;" elsewhere valga is used.

Present Imperative. The old plural form, without the final $d$, is found not only

\section{A N D MONOGRAPH S}




\begin{tabular}{|c|c|}
\hline 360 & GARCILASO DE LA VEGA \\
\hline & $\begin{array}{l}\text { before os, as Quedaos (Egl. II, 635), but } \\
\text { also in several verbs of the first conjuga- } \\
\text { tion in other situations, for example: llevá, } \\
\text { mirá, soltá, tornáme, abraçá, and essecutá. } \\
\text { Juan de Valdés condemns these forms. } \\
\text { There is an example of metathesis in } \\
\text { dezildo (Egl. I, 236). } \\
\text { Future Indicative. The older forms, } \\
\text { showing metathesis, such as terné, porné, } \\
\text { verné, and averné are regularly used, al- } \\
\text { though tendrá occurs (Canc. II, } 32 \text {; Son. } \\
\text { XI, I I). The separation of the auxiliary } \\
\text { from the infinitive is illustrated in dexarte } \\
\text { he (Egl. II, I } 765 \text { ). Possibly contarte (Egl. } \\
\text { II, IO39) stands for contarte he. } \\
\text { Preterite Indicative. Vido (6 examples) } \\
\text { occurs beside vió. The preterite of traer } \\
\text { is regularly truxe. In several preterites we } \\
\text { find a form without palatalization of the } \\
\text { stem vowel, as arrepentió or convertieron. } \\
\text { Conduxieron shows the older form with } \\
\text { the palatal still unabsorbed by the } x \text {. } \\
\text { Past Subjunctives. Analogous to truxe } \\
\text { is truxiesse. Ovieron shows the original } \\
\text { vowel, before the palatal influence has }\end{array}$ \\
\hline & H I S P N I C NOTES \\
\hline
\end{tabular}




\section{I F E A N W O R K S}

361

exerted its effect. Dixiera, dixiesse and conduxiesse are like conduxieron.

Present Participle. There is hesitation between dormiendo and the modern form durmiendo. Reyendo is the normal form before the raising of the initial $e$ to $i$.

Present Infinitive. The final $r$ of the infinitive is regularly assimilated to a following $l$, which in turn gives palatal $l l$ : vellas, dezillo, etc. There are, however, a few examples of $r l$ : cercarlo (Egl. III, 205), mirarla (Egl. III, I42).

SYNTAX. The syntax of Garcilaso calls for little comment. His usage of the subjunctive, both in principal and secondary clauses, is eminently modern. There are two examples of the absolute construction imitated from the so-called "Greek accusative" in Latin: "El fiero cuello atados" (Canc. V, I9), and "Las venas dulcemente desatado" (El. II, I44). It is found with increasing frequency in the poets of the Golden Age, particularly in Góngora. Another Latinizing expression is "luziente de cristal coluna" (El. I, 73) following the

\section{A N D MONOG R A P S}




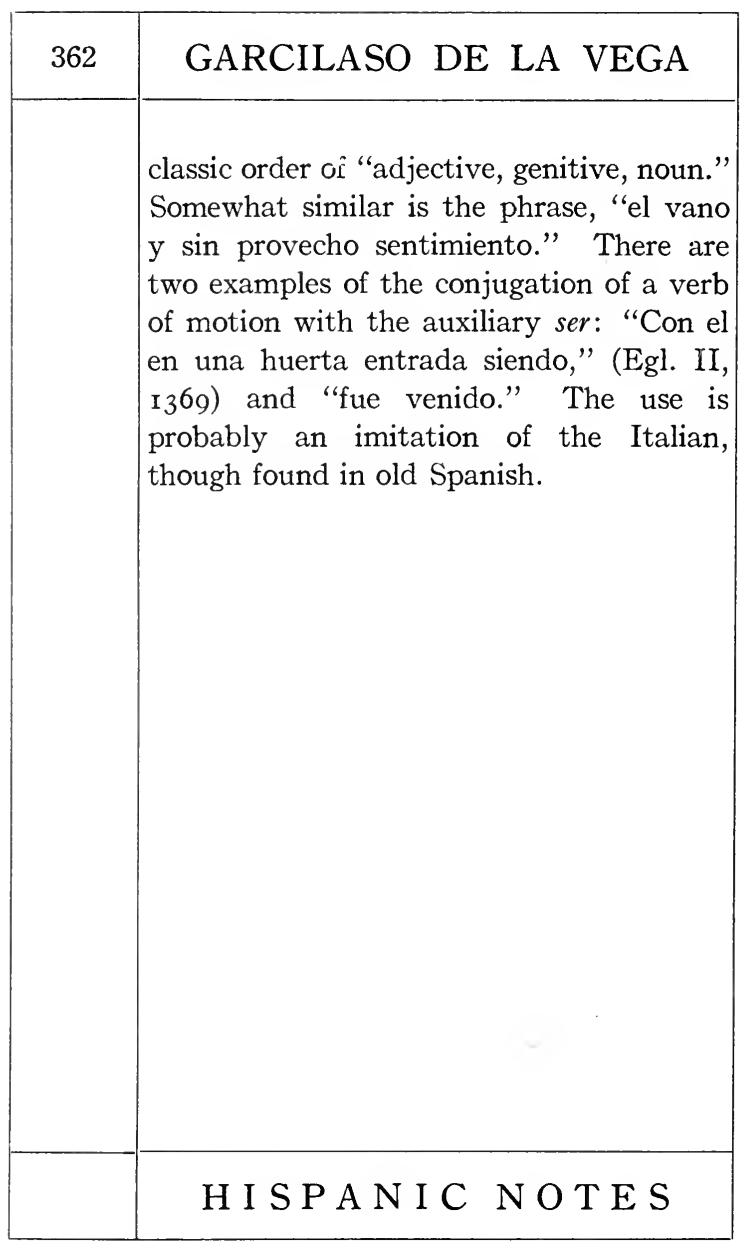




\section{LIFE A N D WORK S}

\section{CHAPTER VI}

\section{THE FORTUNA OF GARCILASO}

\section{EARLY MENTIONS}

Among his contemporaries Garcilaso was held in esteem by a limited circle of men of letters, of whom we have had occasion to speak in tracing his life. Boscán and Sá de Miranda in the Peninsula, and in Italy, Bembo, Tansillo and Scipione $\mathrm{Ca}$ pece bore testimony to the regard in which they held him as a gentleman and as a poet; and we have seen evidences of his intimate relations with other poets and scholars of the day. Upon Boscán and Sá de Miranda in particular he exercised a notable influence.

From the first he was the comrade of the former. The value of his advice and example bore no small part in encouraging him in his effort to write in the new rhythms and in some of these combinations, such

\section{A N D MONOGRAPHS}




\begin{tabular}{|c|c|}
\hline 364 & GARCILASO DE LA VEGA \\
\hline & $\begin{array}{l}\text { as the octave, blank verse, the inner rhyme, } \\
\text { and the lira, it was he who led the way } \\
\text { and offered the models for his friend's } \\
\text { guidance. } \\
\text { Sá de Miranda has left clear proof of the } \\
\text { influence which Garcilaso exerted upon } \\
\text { him. In a passage in the dedication of his } \\
\text { eclogue Nemoroso, written on the first } \\
\text { anniversary of Garcilaso's death, he declares, } \\
\text { Enviasteme el buen Laso, } \\
\text { iré paseando asi mi paso a paso. } \\
\text { Al qual gran don io quanto } \\
\text { devo sabreis; que ardia } \\
\text { temiendo i deseando juntamente, } \\
\text { (Egl. V, 64-68) } \\
\text { and elsewhere he shows that for him, at } \\
\text { least, Garcilaso was the real initiator of } \\
\text { the new school, } \\
\text { Que tu fuiste el primero } \\
\text { que enchiste el bosque del son estranjero. } \\
\text { (id., 503-4) } \\
\text { Even before the death of the Castilian } \\
\text { poet, he seems to have known his work, } \\
\text { for there is a line in his eclogue Celia } \\
\text { (I } 535 \text { ), }\end{array}$ \\
\hline & H I P A N I C N T E S \\
\hline
\end{tabular}




\section{I.FE A N D W O R K S}

Corren lagrimas justas sin parar,

(Egl. III, 55)

which appears to be an echo to the refrain in the song of Salicio,

Salid sin duelo, lagrimas, corriendo.

(Egl. I, 70) ${ }^{1}$

Perhaps it is to this answer that Garcilaso is referring in the third Eclogue when he says,

. . y lleva presuroso

al mar de Lusitania el nombre mio, donde estara escuchado, yo lo fio.

$$
\text { (Egl. III, 246-48) }
$$

In form as well Sá de Miranda shows his indebtedness to Garcilaso. The eclogue Nemoroso is polymetric, like the second Eclogue, and the various metrical combinations are precisely those used by the Spanish poet: canzone stanzas (the form is that used by Garcilaso, lines 38-76), tercets and inner rhymes. It should be noted, however, that the latter belong to the type with the inner rhyme on the fourth syllable, following the type used by Sannazaro in his second egloga, rather

\section{A N D MONOGRAPH S}




\begin{tabular}{|c|c|}
\hline 366 & GARCILASO DE LA VEGA \\
\hline & $\begin{array}{l}\text { than that of Garcilaso, with the rhyme on } \\
\text { the sixth syllable. The eighth eclogue, in } \\
\text { Portuguese, and the ninth, in Castilian, are } \\
\text { also polymetric, illustrating a variety of } \\
\text { metres, including the octave and the inner } \\
\text { rhyme with the rhyme on the sixth syllable. } \\
\text { The genius of Sá de Miranda was akin } \\
\text { to that of Garcilaso; not in vain did the } \\
\text { Portuguese poet recall their common } \\
\text { ancestry. Like his Castilian contemporary } \\
\text { he early came under the influence of the } \\
\text { Italian poets; his first attempts in their } \\
\text { measures are almost exactly contemporary } \\
\text { with the early experiments of Boscán and } \\
\text { Garcilaso. His best work shows the same } \\
\text { qualities of delicate finish and keen ear for } \\
\text { melodic beauty. And it is particularly sig- } \\
\text { nificant of his esteem for Garcilaso that } \\
\text { he, an ardent worshipper of his Italian } \\
\text { models, should have placed the Spanish } \\
\text { poet among his masters, acknowledging } \\
\text { him to be the equal of Petrarch or his fol- } \\
\text { lowers. } \\
\text { The years which immediately followed } \\
\text { Garcilaso's death have left no evidence }\end{array}$ \\
\hline & H I P A N I C NOTES \\
\hline
\end{tabular}




\section{LIFE A N D W ORKS}

that his memory was widely cherished. Save in the official documents which bespeak the Emperor's continued concern for his family, he is wellnigh forgotten. Boscán, it is true, commemorated his loss in two deeply felt sonnets, which rank among his best works. The second deserves quoting for its unaffected sincerity,

Garcilasso, que al bien siempre aspiraste y siempre con tal fuerça le seguiste que a pocos passos que tras el corriste, en todo enteramente le alcançaste,

dime ¿por que tras ti no me llevaste, quando desta mortal tierra partiste? ¿por que al subir a !o alto que subiste aca en esta baxeza me dexaste?

Bien pienso yo que si poder tuvieras de mudar algo lo que esta ordenado, en tal caso de mi no te olvidaras;

que, o quisieras honrrarme con tu lado, o a lo menos de mi te despidieras, o, si esto no, despues por mi tornaras.

(Son. XCII)

And again, in the Octava rima, he refers to him affectionately as a noble gentleman and as a poet in Latin and Castilian,

\section{A N D MONOGRAPHS}




\begin{tabular}{|c|c|}
\hline 368 & GARCILASO DE LA VEGA \\
\hline & $\begin{array}{l}\text { Esta virtud le dio con larga mano, } \\
\text { el bien que casi a todo el mundo niega, } \\
\text { con su verso Latino y Castellano, } \\
\text { que desde el Helicon mil campos riega, } \\
\text { iO dichoso amador! iDichoso amado! } \\
\text { que del amor acrecento el estado. (p. 446) } \\
\text { Another poet, Gutierre de Cetina, also } \\
\text { mentions him in a letter to Diego de } \\
\text { Mendoza. }{ }^{1} \text { But the impression which he } \\
\text { left upon his generation was slight; had } \\
\text { his works perished, his memory would } \\
\text { have quickly vanished. } \\
\text { The publication of his poems, along with } \\
\text { those of Boscán, in I } 543 \text { soon bore fruit. } \\
\text { Their wide popularity among the reading } \\
\text { public is revealed by the fact that within } \\
\text { ten years there were no less than twelve } \\
\text { editions, including those printed in Italy, } \\
\text { Flanders, France and Portugal. As early } \\
\text { as I } 546 \text { we find a critical opinion of the } \\
\text { value of the poetry of Boscán and Gar- } \\
\text { cilaso in the Discurso sobre la lengua caste- } \\
\text { llana of Ambrosio de Morales, printed with } \\
\text { the Obras of Francisco Cervantes de Sala- } \\
\text { zar. }{ }^{2} \text { Recognizing the importance of }\end{array}$ \\
\hline & H I S A N I C NOTES \\
\hline
\end{tabular}




\section{I F E A N D W O R K S}

Boscán's service as a pioneer, Morales observes that his imitation of the Italians would have had little effect without the greater talents of Garcilaso, whose work he does not hesitate to compare with that of the Latin as well as the Tuscan poets.

Three years later ( 1549 ), in a passage interpolated in his translation of the Orlando furioso, Gerónimo de Urrea shows an acquaintance with Garcilaso's tribute to Doña María Enríquez, the Duchess of Alba, in the second Eclogue, and at the same time pays a conventional tribute to our poet,

Renaldo dixo: ¿quien avra en el suelo que tal empresa tome y osadia?

- Sera este Garcilasso, a quien el cielo hara inmortal, el marmol respondia. ${ }^{1}$

Of a different sort is the comment of Alfonso García Matamoros in his De adserenda Hispaniorum eruditione (I553); admitting the excellencies of the poets of the new school and their fitness for comparison with their Italian masters, he shows clearly

\section{A N D MONOGRAPH S}




\begin{tabular}{|c|c|}
\hline 370 & GARCILASO DE LA VEGA \\
\hline & $\begin{array}{l}\text { his personal leaning to the older Castilian. } .^{1} \\
\text { The significant point in his criticism is the } \\
\text { recognition of the existence of this new } \\
\text { school. } \\
\text { 2. THE ITALIAN scHool of POETs. } \\
\text { The first work published in Spain after } \\
\text { the appearance of the Obras of Boscán and } \\
\text { Garcilaso, to contain hendacasyllables was } \\
\text { the translation of the Arcadia of Sanna- } \\
\text { zaro, printed at Toledo in I } 547^{2} \text { The } \\
\text { verse eglogas, translated by Diego de } \\
\text { Salazar, are in décimas, but a portion of } \\
\text { Egloga X, is done in the original measure, } \\
\text { - hendecasyllables with inner rhymes on } \\
\text { the sixth syllable, - and the concatena- } \\
\text { tion of its opening and closing rhymes } \\
\text { with those of the décimas which precede } \\
\text { and follow is also taken from Sannazaro. } \\
\text { Although it is probable that the use of this } \\
\text { unusual form is derived directly from the } \\
\text { original, it is not impossible that Salazar } \\
\text { was familiar with Garcilaso's experiment } \\
\text { in the same form. }\end{array}$ \\
\hline & H I S P N IC NOTES \\
\hline
\end{tabular}




\section{LIFE A N D WORK S}

The earliest example of a sonnet is one by Juan Hurtado de Mendoza in Diego Gracián's translation of the Morales of Plutarch (Alcalá, I548). ${ }^{1}$ The same edition also contains an anonymous sonnet, translating a Greek epigram, and a "tercia rima" by Luis Hurtado, written in perfectly regular tercets. The following year saw the publication of Urrea's translation of the Orlando furioso in octaves, with an introductory sonnet by Juan Aguilón. ${ }^{2}$

From 1550 on, the number of works written wholly in the Italian measures or containing introductory verses in the new style, is so large that it is necessary to mention only a few. Thus in 1550 there appeared Gonzalo Pérez's translation of the Odyssey in strongly iambic versos sueltos, ${ }^{3}$ and also a new translation of the Orlando furioso in octaves by Hernando de Alcocer. ${ }^{4}$ Of particular interest is the Buen plazer trobado en treze discantes de quarta rima castellana, segun imitacion de trobas francesas (I $55^{\circ}$ ) of Juan Hurtado de Mendoza. ${ }^{5}$ All of the verses in the work are either

\section{A N D MONOGRAPHS}




\begin{tabular}{|c|c|}
\hline 372 & GARCILASO DE LA VEGA \\
\hline & $\begin{array}{l}\text { hendecasyllables or septenaries of the } \\
\text { Italian type, and there are a number of } \\
\text { sonnets included. But most of the work } \\
\text { is written, as the title suggests, in quatrains, } \\
\text { rhyming: ABAB: BCBC: etc. ' The pro- } \\
\text { logue shows another experiment which the } \\
\text { author calls "rima doble castellana segun } \\
\text { imitacion de troba francesa", and which } \\
\text { in reality is merely a series of hendeca- } \\
\text { syllables rhymed in couplets, a favorite } \\
\text { form of Clement Marot. Juan Hurtado } \\
\text { de Mendoza's efforts to introduce French } \\
\text { forms for his Italian rhythms was wholly } \\
\text { unfruitful, but it stands as an interesting } \\
\text { landmark of the struggle between the new } \\
\text { school and the old. The traditional pres- } \\
\text { tige of the Castilian measure was gone; the } \\
\text { triumph of the new school was not yet } \\
\text { complete. And one venturesome spirit at } \\
\text { least essayed to wander in new and un- } \\
\text { trodden paths. } \\
\text { Passing over a sonnet found in the } \\
\text { Villancicos y canciones (I55I) of Juan } \\
\text { Vázquez, and the Cristopathia in octaves } \\
\text { by Juan de Quirós, which appeared in }\end{array}$ \\
\hline & H I P A N I NOTES \\
\hline
\end{tabular}




\section{LIFE A N D W ORK S}

I $55^{2,1}$ we find in 1554 a number of works in the new forms, such as Hozes' translation of the Trionfi of Petrarch in tercets,? Alonso de Lobera's version of the Rissa $y$ planto de Democrates y Heraclito of Fileremo Fregoso, also in tercets, ${ }^{3}$ numerous poems in the Italian measures in the Obras of Jorge de Montemayor, ${ }^{4}$ and finally the important Cancionero genera! de obras nuevas nunca hasta aora impressas, assi por ellarte española como por la toscana. ${ }^{5}$

Hernando de Hozes, the translater of Petrarch, brings us further proof of the rapidity with which the new style had gained ground, for he tells us that "since Garcilaso de la Vega and Juan Boscán brought to our tongue the measures of Tuscan verse, everything written or translated in any of the verses formerly used in Spain has so far lost credit that no one will tolerate them, although some of them are of great value, as everyone knows." 6 Elsewhere Hozes mentions others who are cultivating the Italian style: Diego Hurtado de Mendoza, Gonzalo Pérez, and

\section{A N D M O O G R P H S}




\begin{tabular}{|c|c|}
\hline 374 & GARCILASO DE LA VEGA \\
\hline & $\begin{array}{l}\text { Juan de Coloma. García Matamoros, in } \\
\text { the passage already mentioned had also } \\
\text { mentioned Gonzalo Pérez and in addition, } \\
\text { Juan Hurtado de Mendoza. }{ }^{1} \\
\text { From other sources we can add to our } \\
\text { knowledge of the names at least of other } \\
\text { members of the new school. Urrea as } \\
\text { early as I } 549 \text { had referred in his Orlando } \\
\text { furioso to Juan de Heredia, Luis Zapata, } \\
\text { Garcilaso the Younger, Guálvez, Morrano, } \\
\text { Pero Mexía, Vandalio (Gutierre de Cetina), } \\
\text { Haro, and Gonzalo Pérez. Similarly Gre- } \\
\text { gorio Henríquez de Velasco, in the Parergon } \\
\text { introduced in Libro III of his translation } \\
\text { of Sannazaro's De partu Virginis (I554), } \\
\text { lauds the poets of his time. The first of } \\
\text { his group is Garcilaso the Younger, } \\
\text { un Garci-Laso, hijo digno veo } \\
\text { de Garci-Laso, espiritu divino. } \\
\text { and he also mentions Juan Hurtado de } \\
\text { Mendoza, Diego de Mendoza, Juan Co- } \\
\text { loma, Urrea, and Acuna. Other poets to } \\
\text { whom he refers, such as Bernardino de } \\
\text { Ayala, Antonio de Heredia, Antonio de } \\
\text { Soria, Caravajal, and Oliver, are less known. }\end{array}$ \\
\hline & H I P A N I C NOTES \\
\hline
\end{tabular}




\section{LIFE A N D WORK S}

Finally Luis Zapata in Canto XXXVIII of his Carlo famoso, mentions Diego de Mendoza, Juan Hurtado de Mendoza, Gerónimo de Urrea, Gonzalo Pérez. Fernando de Acuña, Juan Coloma, and Montemayor of the better known writers and also Francisco de Guzmán, Juan de Borja, Juan Fernández de Heredia, Antonio de Soria, Gerónimo Samper, Pedro de Guzmán, and Bernardino de Ayala. ${ }^{1}$

We have already referred to the work of Urrea, Gonzalo Pérez, father of the great secretary, and Juan Hurtado de Mendoza. We shall find (xamples of the verse of some of the others in the Cancionero general de I554. This collection of poems of the reign of Charles $\mathrm{V}$ is singularly interesting, as Wolf observed, ${ }^{2}$ in its revelation of the conflict of the new and old schools. The first ninety poems belong to the old Castilian style; there follow eightythree works in the new measures: "Siguense las obras que van por el arte toscana, compuestas por diverśos autores, nunca hasta aora impressas." Although

\section{A N D M O N O R A P H S}




\begin{tabular}{|c|c|}
\hline 376 & GARCILASO DE LA VEGA \\
\hline & $\begin{array}{l}\text { the names of only two of the authors, Juan } \\
\text { de Coloma and Diego de Mendoza, are } \\
\text { mentioned, there are included some forty- } \\
\text { six sonnets by "different authors". One } \\
\text { of these (No. CXXXII) is the work of } \\
\text { Gutierre de Cetina;" of the rest, a number } \\
\text { are translations of Petrarch and Sanna- } \\
\text { zaro, and in general, the style and form } \\
\text { of all are frankly Petrarchan. } \\
\text { The principal place among the works of } \\
\text { the Italian school is held by the poems of } \\
\text { Juan de Coloma, who is represented by } \\
\text { nineteen compositions: three canciones, the } \\
\text { Historia de Orfeo en octava rigma, an ec- } \\
\text { logue, a capitulo, and twenty-two sonnets. } \\
\text { Here the influence of Garcilaso is at once } \\
\text { manifest. Aside from the Historia de } \\
\text { Orfeo, which owes its inspiration undoubt- } \\
\text { edly to the Octava rima of Boscán, and the } \\
\text { term "capítulo" for the type of composi- } \\
\text { tion which Garcilaso has styled an "elegía," } \\
\text { all the compositions follow the models set } \\
\text { by Garcilaso. Of the three canciones, Nos. } \\
\text { I and III are in the stanza used in Gar- } \\
\text { cilaso's Canción III; No. II is in that of }\end{array}$ \\
\hline & H I P A N I C NOTES \\
\hline
\end{tabular}




\section{LIFE A N D WORKS}

Garcilaso's Canción I, and the sonnets follow the same types. The Eclogue shows even more definitely Coloma's indebtedness to Garcilaso, following the polymetric form of Ec'ogue II in great detail. All the metrical forms used by our poet are employed: tercets, canzone stanzas (the form is precisely that of lines $38-76$ ) and inner rhymes on the sixth syllable. ${ }^{1}$. There is also a brief passage in versos sueltos. The fiction of the eclogue as well follows the same eclogue of Garcilaso and there are frequent reminiscences of phrase or thought. Juan de Coloma's verse gives little sign of originality and his hendecasyllables are usually as stiff and stilted as those of Boscán. But once more, as an innovator, he deserves a place in the company of those who shared in the establishment of modern Spanish verse.

Diego Hurtado de Mendoza, who is represented in the Cancionero general de I55t by eight compositions in the arte toscana and a Castilian copla, is unquestionably the most influential convert to the Italian

\section{A N D MONOGRAPHS}




\begin{tabular}{|c|c|}
\hline 378 & GARCILASO DE LA VEGA \\
\hline & $\begin{array}{l}\text { school. The distinction of his family and } \\
\text { his personal reputation as a scholar and } \\
\text { diplomat, as well as his undoubted gift in } \\
\text { the older forms, gave him a prestige which } \\
\text { cannot have failed to give his accession to } \\
\text { the side of the innovators great weight in } \\
\text { his generation. Although it is impossible } \\
\text { to fix a date, it is probable that his earliest } \\
\text { experiments are almost contemporary with } \\
\text { those of Boscán and Garcilaso. Certainly } \\
\text { before the former's death in I } 542 \text { he had } \\
\text { acquired a real mastery of the new rhythm, } \\
\text { as shown in his Epistola addressed to him. } \\
\text { This poem had already been printed with } \\
\text { the works of Boscán; with the few verses } \\
\text { contained in the present Cancionero and a } \\
\text { stray dedicatory sonnet, it remained the } \\
\text { only poetic work of Mendoza known until } \\
\text { the appearance of his Obras in I6ro. }{ }^{1} \text {. } \\
\text { The poems in the Cancionero are: two } \\
\text { canciones, (Nos. II-III of Knapp's edition), } \\
\text { an elegy (No. I), a copla, an eclogue (No. } \\
\text { I), and four sonnets (Nos. II, III and XI } \\
\text { and a version of Garcilaso's Son. XXVII). } \\
\text { The two canciones are in stanzas already }\end{array}$ \\
\hline & H I P A N I NOTES \\
\hline
\end{tabular}




\section{LIFE A N D WORK S}

used by Garcilaso (Canc. II and Egl. II). The eclogue is polymetric, in tercets and canzone stanzas. The stanza form is an unusual one: $\mathrm{ABCD}: \mathrm{ABCD}: \mathrm{dEeFF}$, which is not found in Petrarch nor his imitators and there is included a sort of envoy in two stanzas (one translating the comparison of Ausias March between Love and the tight garment), in a different form: $\mathrm{aBbCcC}$. The device on which the eclogue is based is the stock Virgilian scheme, used by Garcilaso in both the first and third Eclogues: the poet introduces two shepherds who chant in turn their songs, in this case their laments.

As M. Morel-Fatio has pointed out, ${ }^{1}$ the Elegy is written in a curious form: after two introductory tercets: $\mathrm{ABC}$ : $\mathrm{ABC}$, the rest of the poem is in seven line stanzas. But he did not add that these stanzas are bound together by the rhymes: CDEFFED: DGHIIHG, etc. It is interesting to find once more evidence of an attempt to create new forms. The essays of Diego de Mendoza had no greater success than those of

\section{A N D MONOGRAPHS}




\begin{tabular}{|c|c|}
\hline 380 & GARCILASO DE LA VEGA \\
\hline & $\begin{array}{l}\text { Juan Hurtado de Mendoza, but they save } \\
\text { the school from the charge of absolute ste- } \\
\text { rility in invention. } \\
\text { Certain other poets whose names we } \\
\text { have mentioned as among the early adher- } \\
\text { ents of the Italian school deserve a further } \\
\text { word. Chief among these are Fernando de } \\
\text { Acuna and Gutierre de Cetina. Acuna's } \\
\text { first verses were written in Italy in the } \\
\text { years immediately following Garcilaso's } \\
\text { death and most of his works are in the } \\
\text { Italian style. To him we owe the first } \\
\text { imitation of the lira, a parody addressed } \\
\text { to Gerónimo de Urrea, "buen caballero y } \\
\text { mal poeta," whose translation of Le cheva- } \\
\text { lier délibéré was a rival of his own. He } \\
\text { also uses the same form in a pastoral } \\
\text { song, "Damon, ausente de Galatea." The } \\
\text { celebrity of this parody may have had } \\
\text { some part in popularizing the form. } \\
\text { Gutierre de Cetina is jestingly referred } \\
\text { to by Diego de Mendoza in his Epistola to } \\
\text { Boscán; his own Epistola to Mendoza was } \\
\text { written in I } 543 .^{2} \text { One of his sonnets (No. } \\
\text { CXCIII) was printed in the Obras of }\end{array}$ \\
\hline & H I P A N I NOTES \\
\hline
\end{tabular}




\section{LIFE A N D W OR K S}

381

Montemayor (I554); another (CCXXXII) was included in the Cancionero general de 1554; a few of his poems were included in Herrera's notes to Garcilaso. But his works as a whole remained unpublished until recently. Although there is no evidence of any direct influence from Garcilaso in his works, he had a large part in the perfection of the Italian forms and in some respects is the most Petrarchan of the group. His daintiness and his subtlety have a fragile charm. To him moreover we owe the introduction into Castilian of two additional forms: the madrigal, so admirably employed in his "Ojos claros, serenos," and the sextina, also used by Fernando de Acuña but never successfully grafted in Spain. ${ }^{1}$

The last of the poets in the new school who shows the influence of Garcilaso is Agustín Guedeja y Quiroga. The only one of his works to survive, an eclogue printed as a cancion among the works of Diego de Mendoza, ${ }^{2}$ is closely modeled upon Garcilaso's first Eclogue, using the same Pe-

\section{A N D MONOGR A P H S}




\begin{tabular}{|c|c|}
\hline 382 & GARCILASO DE LA VEGA \\
\hline & $\begin{array}{l}\text { trarchan stanza, imitating much of the } \\
\text { phraseology and ending with a specific } \\
\text { reference to our poet, for after the shep- } \\
\text { herd Dafni has stirred to compassion the } \\
\text { nymphs of the Alabón (probably used for } \\
\text { the Alagón, a stream which has its source } \\
\text { in the Peña de Francia, near Salamanca), } \\
\text { he crosses to the Tormes and there, } \\
\text { Mas allá en la corriente } \\
\text { de Tormes caudaloso, } \\
\text { cantó con Nemoroso, } \\
\text { adonde publicó más sus dolores. } \\
\text { The sweep of the new movement was } \\
\text { rapid in Spain. Twenty years after Gar- } \\
\text { cilaso's death his verses had become the } \\
\text { model for poetic composition. With the } \\
\text { appearance of some sonnets in Castilian in } \\
\text { the I } 557 \text { edition of Castillo's Cancionero } \\
\text { general, which had represented the tradi- } \\
\text { tional Spanish metres for almost half a } \\
\text { century, we may consider the "arte to- } \\
\text { scana" as definitely established in Spain. } \\
\text { 3. opponents of THE NEw school } \\
\text { The rapid growth of the popularity of } \\
\text { the new forms had not been wholly with- }\end{array}$ \\
\hline & H I S P A I C N O T E S \\
\hline
\end{tabular}




\section{L.IFE A N D WORKS}

out opposition in the Peninsula. One, at least, of the poets of the time, Cristóbal de Castillejo, had raised his voice in protest against this influx of foreign influence. His verses, "Contra los que dexan los metros castellanos y siguen los italianos," ${ }^{1}$ are a half-serious, half-jesting attack on the new school, in particular on Boscán and Garcilaso, although he names Diego de Mendoza and Luis de Haro as additional defendants. Castillejo is eminently serious in his respect for the older writers from Juan de Mena to Torres Naharro. His jesting is the more piquant because he clothes his attacks in the very forms these foreign innovators use: a sonnet, supposed to be by Boscán, an octave which he attributes to Garcilaso, and a final sonnet for which he himself assumes responsibility. The purpose of these parodies is clear. Castillejo is anxious to show that anyone can write perfect sonnets, - if he cares to;

Facilmente los hiciera, pues los hice en la romana,

\section{A N D MONOGRAPHS}




\begin{tabular}{|c|c|}
\hline 384 & GARCILASO DE LA VEGA \\
\hline & $\begin{array}{l}\text { says Torres Naharro, when consulted. And } \\
\text { the tolerance with which he views the new } \\
\text { movement is shown in the decision of his } \\
\text { bards; they grant their praises to the new } \\
\text { singers because of their courtly polish and } \\
\text { their contributions to letters through their } \\
\text { works in the new style. } \\
\text { These coplas of Castillejo were certainly } \\
\text { written before I 549, for Urrea refers to } \\
\text { them distinctly in his translation of the } \\
\text { Orlando furioso, } \\
\text { Y con el, Castillejo, amigo caro, } \\
\text { que tanto en fama y obras resplandece, } \\
\text { a ver viene, muy lleno de alegria, } \\
\text { esto que nombra secta o heregia, } \\
\text { having in mind the opening stanza of } \\
\text { Castillejo, } \\
\text { Pues la Santa Inquisicion } \\
\text { suele ser tan diligente } \\
\text { en castigar con razon } \\
\text { qualquier secta y opinion, } \\
\text { levantada nuevamente, } \\
\text { resucite su lucero } \\
\text { a castigar en España } \\
\text { una muy nueva y extraña, }\end{array}$ \\
\hline & H I S P A I C NOTES \\
\hline
\end{tabular}




\section{IFE A N D W ORK}

como aquella de Lutero

en las partes de Alemaña.

These burlesque verses of Castillejo are his only compositions in the Italian measures. He died in $155^{\circ}$ before the triumph of the new school was complete.

Another opponent of the new style was Gregorio Silvestre, who attacks it sharply for its emptiness and its obscurity in his Audiencia de Amor;

Dijo Amor: ¿Donde se aprende este metro tan prolixo que las orejas ofende? Por estas coplas se dixo algarabia de allende. El sugeto frio y duro, y el estilo tan oscuro que la dama en quien se emulea duda, por sabia que sea, si es requiebro o si es conjuro. Ved si la invencion es basta, pues Garcilaso y Boscan, las plumas puestas pcr asta, cada uno es un Roldan; $\mathbf{y}$ con todo no le basta. ${ }^{1}$

\section{A N D MONOGRAPHS}




\begin{tabular}{|l|l|}
\hline 386 & \multicolumn{1}{|c|}{ GARCILASO DE LA VEGA } \\
\hline $\begin{array}{l}\text { But Silvestre was ultimately converted to } \\
\text { the new doctrine; most of his verses, pub- } \\
\text { lished in I 582, are in hendecasyllables, and } \\
\text { he is even said by his editor, Pedro de } \\
\text { Cáceres y Espinosa, to have been the first } \\
\text { to give them their proper rhythm! This } \\
\text { tendency to write in both styles, which we } \\
\text { find in Boscán, Diego de Mendoza, and } \\
\text { even Garcilaso, became a characteristic of } \\
\text { the poets of Spain. Sebastián de Horozco } \\
\text { of Toledo is almost the only poet of the } \\
\text { last half of the sixteenth century whose } \\
\text { cancionero is wholly in the Castilian meas- } \\
\text { ures. } \\
\text { The adoption of the new metres was not } \\
\text { revolutionary; they did not replace, but } \\
\text { rather supplemented the older forms, en- } \\
\text { riching the poetic expression of Spain with } \\
\text { numerous varied forms. It is not surpris- } \\
\text { ing that the process was so quickly carried } \\
\text { out; that in less than two decades, sonnets } \\
\text { were as frequent as the coplas of the past. } \\
\text { The early influence of Boscán and Gar- } \\
\text { cilaso was largely formal, but they did open } \\
\text { the eyes of their fellow-countrymen to the }\end{array}$ \\
\hline \begin{tabular}{l} 
H I S P A N I C N O T E S \\
\hline
\end{tabular} \\
\hline
\end{tabular}




\section{IFE A N D WORKS}

beauties of Petrarch and of Sannazaro and even in their earliest followers there is evident an effort for that polish and elegance which were so strikingly exemplified by the work of the poet of Toledo.

\section{THE ANNOTATED EDITIONS}

The first of the critics of the new school had, as we have seen, clearly celebrated the superiority of Garcilaso's art over that of Boscán. His judgment was corroborated by the testimony of all his successors and by none more plainly than by the public, which has encouraged the publishers to reprint the works of Garcilaso in edition after edition, while the verses of his contemporary have fallen into complete obliv-

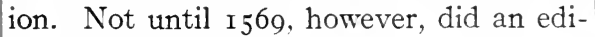
tion of the poems of Garcilaso alone appear. In that year Simón Borgonon, a publisher of Salamanca, issued from the press of Matías Gast a slender volume containing the verses which had formed till then the Fourth Book of the Obras of Boscán. In his dedication, Borgoñón alleges as his motive

\section{A N D MONOGRAPHS}




\begin{tabular}{|c|c|}
\hline 388 & GARCILASO DE LA VEGA \\
\hline - & $\begin{array}{l}\text { the fact that many people were separating } \\
\text { the works of Garcilaso from the rest of the } \\
\text { book (the public, it seems, was already dis- } \\
\text { criminating), and further remarks that he } \\
\text { had secured the services of men of taste to } \\
\text { emend the text. That this new venture } \\
\text { met with favor is clear from the appearance } \\
\text { in the following year of a reprint by } \\
\text { Alonso Gómez of Madrid. They were } \\
\text { tiny books, easily lost or discarded. Dili- } \\
\text { gent search has failed to discover more } \\
\text { than a single copy of each of them, the } \\
\text { former in the Biblioteca Nacional, the lat- } \\
\text { ter in the Library of the Hispanic Society } \\
\text { of America. } \\
\text { The success of these editions soon stimu- } \\
\text { lated further interest in Garcilaso. Another } \\
\text { printer of Salamanca, Pedro Lasso, secured } \\
\text { the services of one of the most distinguished } \\
\text { professors in the University, Francisco } \\
\text { Sánchez de las Brozas, the great Humanist } \\
\text { who occupied the chair of rhetoric, to pre- } \\
\text { pare an improved and annotated edition } \\
\text { of his works. In November, I } 573 \text { the } \\
\text { manuscript was ready and sent to Juan }\end{array}$ \\
\hline & H I P A N I N OTES \\
\hline
\end{tabular}




\section{LIFE A N D WORKS}

Vázquez del Mármol for examination. Printing was under way in January, 1574 and the License was granted on the 28 th of the month. But the printer was tempted by a cash offer to produce an edition of the Horae B. Mariae and so the printing of Garcilaso's verse was postponed, - - to the printer's financial loss, Sánchez opined, for the students who were leaving for the vacation, would all have been glad to buy and carry home a copy. ${ }^{1}$

The proofs were finished in May, and in them Sánchez, much against his judgment at times, followed the suggestions of his clerical patron, omitting the laudatory verses to the Maecenas. Diego López de Zúñiga, which he had intended to include in the preliminaries and thus leaving two leaves blank before the text, rewriting the prologue, "Al lector," and reducing the quotations in the notes. ${ }^{2}$ The little book which came from the press has become almost as rare as the two earlier editions of Garcilaso alone. The only copies known are an imperfect one in the Biblioteca

\section{A N D M O NOGR A P H S}




\begin{tabular}{|l|l|}
\hline 390 & $\begin{array}{l}\text { GARCILASO DE LA VEGA } \\
\text { Nacional, lacking six of the preliminary } \\
\text { leaves, and a perfect copy bought by the } \\
\text { writer in I 9I } 8 \text { and now in the Library of } \\
\text { the Hispanic Society of America. } \\
\text { The edition of El Brocense was a thor- } \\
\text { ough, scholarly piece of work. The text, } \\
\text { freed from numerous misprints, was fur- } \\
\text { ther corrected with the aid of a manu- } \\
\text { script furnished by Tomás de Vega and also } \\
\text { by the penetrating criticism of the editor. } \\
\text { The annotations, largely consisting of the } \\
\text { sources, Latin or Italian, from which Gar- } \\
\text { cilaso's verses are derived, are pointed and } \\
\text { illuminating. The relation of Garcilaso } \\
\text { to the earlier writers and to his Italian } \\
\text { contemporaries was once for all established. } \\
\text { The purpose of El Brocense was avowedly } \\
\text { to demonstrate that Garcilaso was worthy } \\
\text { of comparison with the Classics; a true } \\
\text { son of the Renaissance, he counted imita- } \\
\text { tion as the first requisite of a poet, "digo } \\
\text { y affirmo que no tengo por buen poeta al } \\
\text { que no imita a los excellentes antiguos."' } \\
\text { But not all his literary friends were of the } \\
\text { same mind; they expressed their objec- }\end{array}$ \\
\hline H I S P A N I C N O T E S \\
\hline
\end{tabular}




\section{I F E A D W O R K}

tions even before the edition was in print, and Sánchez, following the suggestion of his counsellor, Juan Vázquez del \ármol, took care to defend his position in his Prologue, calling attention to the fact that the Italians had already performed a similar service in honor of Ariosto and Sannazaro by their annotated editions of the Orlando furioso and the Arcadia.

This explanation of his purpose was not sufficient to silence the protests of his opponents, one of whom composed a burlesque sonnet, "Against the Annotations of Master Sánchez when they were printed for the first time; at the time it was discovered in the house of a gentleman in Salamanca,"

Descubierto se ha un hurto de gran fama del ladron Garci-Lasso, que han cogido con tres dosseles de la reyna Dido y con seys almohadas de la cama,

el telar de Penelope, y la trama de las Parcas y el arco de Cupido, tres barriles del agua del olvido, y un prendedero de oro de su dama.

\section{A N D MONOGRAPHS}




\begin{tabular}{|c|c|}
\hline 392 & GARCILASO DE LA VEGA \\
\hline & $\begin{array}{l}\text { Provosele que avia salteado } \\
\text { siete años en Arcadia y dado un tiento } \\
\text { en tiendas de poetas Florentines. } \\
\text { Es lastima de ver al desdichado, } \\
\text { con los pies en cadena de comento, } \\
\text { renegar de rhetoricos malsines. } \\
\text { Sánchez retorted with a sonnet in the } \\
\text { same rhymes, written on the back of the } \\
\text { original verse and the caption of the answer, } \\
\text { as it appeared in the second edition of } \\
\text { I } 577 \text {, declared that "the name of the op- } \\
\text { posing author is given, with some of his } \\
\text { qualities," } \\
\text { Descubrense poetas, cuya fama } \\
\text { podra tocar las ondas del olvido, } \\
\text { que por henchir el verso mal medido } \\
\text { lo embuten de almohadas de la cama, } \\
\text { y buscan consonantes de la trama } \\
\text { de parcas, tela y arcos de Cupido, } \\
\text { sin sentir en sus versos mas sentido } \\
\text { que siente el prendedero de su dama. } \\
\text { Y quieren dar juyzio, mal pecado, } \\
\text { que tal de Garci-Lasso es el comento, } \\
\text { ladrando a bulto, como los mastines. } \\
\text { Es lastima de ver tan mal ganado, } \\
\text { de largos dientes, corto entendimiento, } \\
\text { mas falsos que corcovos de rocines. }\end{array}$ \\
\hline & H I S A N IC NOTES \\
\hline
\end{tabular}




\section{LIFE A N D W O R K S}

393

As is usual in such polemics, the answer is far inferior to the original and like most retorts of the kind has refuge in the argumentum ad hominem. Gallardo has suggested that the author's name is involved in the "corCovos" of the last line. ${ }^{1}$ A certain Gerónimo de los Cobos is, in fact, mentioned by Herrera, who cites one of his poems in the notes to Garcilaso." If this Cobos was, like Herrera, a Sevillan, there is added reason for his attack upon the Salamancan professor.

Another poet of Old Castile, Gerónimo de Lomas Cantoral, of Valladolid, also sprang to the defense of Sánchez's annotations in another sonnet in the same rhymes, published in his Obras in 1578 ,

Aquel cuya virtud tu lengua infama, si oscurecer su luz algo has podido, mostro cruel, de madre vil nacido, $\mathbf{y}$ del ageno bien que se derrama

ni hurto jamas, ni es cierto lo que trama tu condicion perversa, ni el ha sido preso, ni el baxo nombre a merecido que tu voz mentirosa le da y llama.

\section{A N D MONOGRAPH S}




\begin{tabular}{|c|c|}
\hline 394 & GARCILASO DE LA VEGA \\
\hline & $\begin{array}{l}\text { Antes como a divino ya y dexado } \\
\text { de ti por hombre tal, con nuevo intento } \\
\text { pudieras pretender diversos fines; } \\
\text { sino que solo hieren al que a dado } \\
\text { el mundo justo lauro y digno assiento, } \\
\text { iO fiera bestia! tus palabras ruynes. } \\
\text { His championship of the cause, bad as is } \\
\text { it, is a further indication that the anony- } \\
\text { mous critic of Sánchez's edition belonged } \\
\text { to the Sevillan school. We shall presently } \\
\text { see this strife between the two camps grow- } \\
\text { ing even more bitter. } \\
\text { Three years after the publication of the } \\
\text { second edition of El Brocense, in I } 580 \text {, } \\
\text { there appeared at Seville a new edition } \\
\text { with elaborate notes and commentary by } \\
\text { the poet Fernando de Herrera. At the } \\
\text { beginning of the edition he included a brief } \\
\text { life of the poet, the first effort to trace his } \\
\text { career and still valuable, because some of } \\
\text { his information was obtained from Antonio } \\
\text { Puertocarrero, son-in-law of the Toledan. } \\
\text { In its direct contribution to our knowledge } \\
\text { of Garcilaso's work; his commentary adds } \\
\text { little to the work of El Brocense, but its }\end{array}$ \\
\hline & H I P A N I N N T E S \\
\hline
\end{tabular}




\section{IFE A N D WORKS}

very diffuseness makes it an important source for the study of the poetic theories of the time and moreover, there are included a considerable number of otherwise unknown compositions by contemporary poets. Important as it is in these respects, intrinsically it is ponderous and pompous. Tamayo de Vargas laconically expressed the facts in this style, "Herrera's only purpose is to display his own learning, Sánchez's, to display the imitation of others."'1

5. 'THE CONTROVERSY OVER HERRERA'S EDITION

There is reason for believing that Herrera had begun the task many years before, for he tells us that Juan de Malara was one of those who had most urged him to continue the work which he had begun, ${ }^{2}$ and Malara died in $\mathrm{I}_{57 \mathrm{I}}$. He also specifically claims the title of priority over others, saying, "I venture to say that this edition is beyond comparison more diligently and carefully emended than all those which

\section{A N D MONOGRAPHS}




\begin{tabular}{|c|c|}
\hline 396 & GARCILASO DE LA VEGA \\
\hline & $\begin{array}{l}\text { have thus far been printed; and that I } \\
\text { was the first to set my hand to the task. } \\
\text { For all the corrections, which some people } \\
\text { boast of, pretending that they emended } \\
\text { them through their own ingenuity, were } \\
\text { long ago made by me, before any one con- } \\
\text { cerned himself with the task. But thinking } \\
\text { that such subtleties were of little import- } \\
\text { ance, I disclosed them in many places, } \\
\text { where others have taken advantage cf } \\
\text { them."' } \\
\text { Whether or no Herrera is accurate in his } \\
\text { statement that he was the first to under- } \\
\text { take the task and to emend the text, one } \\
\text { thing is certain: he was acquainted with } \\
\text { Sánchez's edition. Aside from the thinly } \\
\text { veiled reference to it in the passage just } \\
\text { cited, the acquaintance is shown in numer- } \\
\text { ous details of his edition. He prints six } \\
\text { of the nine sonnets which Sánchez had } \\
\text { been the first to publish; in several pas- } \\
\text { sages he rejects specifically the latter's } \\
\text { emendations. But he steadily evades } \\
\text { mentioning his name, boasting the origin- } \\
\text { ality of his own emendation or identifica- }\end{array}$ \\
\hline & H I S P N I C NOTES \\
\hline
\end{tabular}




\section{LIFE A N D W ORKS}

tion of the source, even when it is plain that he is but copying his predecessor, and often going out of his way to suggest a possible parallel, rather than accept the obvious citation of $\mathrm{El}$ Brocense.

This affront was too much for Castilians to bear without protest. It was bad enough for an Andalusian to venture to criticize the work of a pure Toledan; but to claim superiority over one of their friends, the leading scholar of the time and a professor at Salamanca! The first to spring into the fray was a certain Damasio, who sent a long letter, perhaps in verse, from Valladolid to a silversmith in Seville, criticizing Herrera's work.

The attack of Damasio has not survived; we know of it only through a mention of Herrera's. ${ }^{1}$ But there is little doubt that this Damasio may be identified as Damasio de Frías y Balboa, named among the poets of Valladolid in several of the literary catalogues of the time, such as those of Lomas Cantoral ${ }^{2}$, Cervantes, ${ }^{3}$ Vicente Espinel, ${ }^{4}$ or Pedro de Medina. ${ }^{5}$ Several of his

\section{A N D MONOGRAPH S}




\begin{tabular}{|c|c|}
\hline 398 & GARCILASO DE LA VEGA \\
\hline & $\begin{array}{l}\text { poems are printed in Sedano's Parnaso } \\
\text { español }{ }^{1} \text { and an unpublished work, Diálogos } \\
\text { de diferentes materias, mentioned by An- } \\
\text { tonio, }{ }^{2} \text { exists in the Biblioteca Nacional. } \\
\text { This was not his only essay in the field of } \\
\text { polemics, for Herrera refers to an earlier } \\
\text { attack made by him on the Inventario of } \\
\text { Villegas ( } 5^{6} 5 \text { ). Herrera's statement that } \\
\text { he was prompted by the bad example which } \\
\text { Diego de Mendoza had brought from Italy } \\
\text { would seem to be an indication that his } \\
\text { satires were written in verse, for Mendoza } \\
\text { is the first of the poets to use this form. } \\
\text { A second attack was presently directed } \\
\text { at Herrera by another Castilian, who used } \\
\text { the pseudonym of "El Prete Jacopín" and } \\
\text { who sent his Observaciones from Burgos. } \\
\text { Various persons have been suggested as the } \\
\text { real author, but there remains little doubt } \\
\text { that the work is by Juan Fernández de } \\
\text { Velasco, later Gran Condestable of Castile. } \\
\text { Although known to Tamayo de Vargas } \\
\text { and to Nicolás Antonio in the seventeenth } \\
\text { century and to Gallardo in the early } \\
\text { nineteenth century, the satire was not pub- }\end{array}$ \\
\hline & H I P A N IC NOTES \\
\hline
\end{tabular}




\section{I F E A N W W R K S}

lished until 1870 , when it was printed by the Bibliófilos Andaluces. The Condestable was a true Castilian and a man of some learning; his criticisms of Herrera are for the most part sound. His defense of Garcilaso's Castilian is eminently just and in matters of poetic taste, he is often much closer to modern feeling than is Herrera, circumscribed as he was by the artificial rules of an academic school. He has also fallen with no gentle hand upon Herrera's besetting weakness, his pompous style, and occasionally succeeded in pricking the bubble of his erudition. But the personal element is exaggerated; there is so much unnecessary vulgarity that his cause is weakened.

Herrera had allowed the first attack by Damasio de Frías to pass unnoticed, but stung by the wide currency given to the invective of "El Prete Jacopín," he penned an answer under the simple disguise of a Sevillan friend, in which he took up point by point the strictures of his Castilian opponent. Herrera lacked the piquant

\section{A N D MONOGRAPH S}




\begin{tabular}{|c|c|}
\hline 400 & GARCILASO DE LA VEGA \\
\hline & $\begin{array}{l}\text { wit and easy pen of his antagonist; his } \\
\text { reply is ponderous when he attempts to } \\
\text { be humorous and his defense of his original } \\
\text { statements is more often an evasion of the } \\
\text { charge than a controversion of the argu- } \\
\text { ment. His reply closes the acrimonious } \\
\text { debate, which adds little luster to the fame } \\
\text { of Garcilaso, though it may be counted as } \\
\text { an evidence of the place of general esteem } \\
\text { to which his verses had risen. } \\
\text { If the truth be told, not all his country- } \\
\text { men looked with favor on the peculiar dis- } \\
\text { tinction which had befallen him in this } \\
\text { matter of commentary. Luis Zapata, al- } \\
\text { ready getting old, laments in his Mis- } \\
\text { celanea at the divorce of his works from } \\
\text { those of Boscán, declaring that "modern } \\
\text { glossers are making for him companions } \\
\text { whom he never knew in life." And it must } \\
\text { not be forgotten that "El Licenciado } \\
\text { Vidriera" chooses as the only companion } \\
\text { for his Book of Hours on his travels, an } \\
\text { edition of Garcilaso "sin comento.". }\end{array}$ \\
\hline & \\
\hline & H I S A N I C NOTES \\
\hline
\end{tabular}




\section{IFE A N D W O R S}

\section{CHAPTER VI}

\section{EL PRÍNCIPE DE LA POESÍA ESPAÑOLA.}

In the Dedication of his edition, Herrera had styled Garcilaso "El Príncipe de la Poesía Española," and this title, in one form or another, has remained the universal symbol under which readers of every time and tongue have paid him homage. To list even the names of those who have paid tribute to him in his own land would be to survey the history of Spanish literature. ${ }^{1}$ Such an undertaking is impossible, but there are certain phases of the cult of Garcilaso which are of especial interest.

First of all, it is noteworthy that his poetry has appealed to the taste of every generation and school. The changing fads of style have not dimmed his glory; men of every kind of temperament, classicist or Romantic, have turned to his verse

\section{A N D MONOGR A P H S}




\begin{tabular}{|c|c|}
\hline 402 & GARCILASO DE LA VEGA \\
\hline & $\begin{array}{l}\text { in admiration. And even those who have } \\
\text { questioned certain phases of his glory, have } \\
\text { overtly or tacitly accepted the justice of } \\
\text { his fame. } \\
\text { Thus, the group of Sevillan critics, be- } \\
\text { ginning with Argote de Molina and in- } \\
\text { cluding Herrera and Juan de la Cueva, } \\
\text { who were the first to point out that the } \\
\text { hendecasyllable had been found in Spain } \\
\text { long before the movement of Boscán and } \\
\text { Garcilaso, never questioned the perfec- } \\
\text { tion and beauty of the latter's verse. And } \\
\text { in a different way, the pious horror of cer- } \\
\text { tain religious enthusiasts of the late six- } \\
\text { teenth and early seventeenth centuries at } \\
\text { the dangers inherent in his verse is only } \\
\text { another method of confessing their feeling } \\
\text { of its power and charm. } \\
\text { This all-embracing horror of any worldly } \\
\text { delights was the impulse which led a cer- } \\
\text { tain Sebastián de Córdova to publish in } \\
\text { I } 575 \text { an edition of the works of Boscán } \\
\text { and Garcilaso, "trasladadas en materias } \\
\text { christianas y religiosas." Menéndez y } \\
\text { Pelayo has noted the similar atrocities per- }\end{array}$ \\
\hline & H I S A N I C NOTES \\
\hline
\end{tabular}




\section{LIFE A N D WORKS}

petrated on Petrarch's verse earlier in the century. ${ }^{1}$ Garcilaso's fate is another evidence of his position as "the Spanish Petrarch." As an example of the method in Córdova's madness, let us cite this perversion of one of Garcilaso's most charming sonnets (No. XIII),

A Mida las orejas le crecian, $y$ de bestial figura se tornavan, y el tierno pan sus manos transformavan en oro y los manjares que trayan.

En hambre y en dolor se convertian el oro y los thesoros que pujavan; de hambre se moria y no acabavan las ansias que los huesos le royan.

¡O bestial avaricia, o grave daño! ¡Como tu calidad yela y resfria toda virtud con yelo y fuerça brava!

¡O ceguedad, o miserable engaño! Que el abariento le redobla y cria la hambre lo que hambre le causava. ${ }^{2}$

In general his plan is a simple one: Biblical allusions replace pagan mythology; mystic love displaces the amours of Garcilaso's shepherds and shepherdesses. Thus he

\section{A N D MONOGRAPHS}




\begin{tabular}{|c|c|}
\hline 404 & GARCILASO DE LA VEGA \\
\hline & $\begin{array}{l}\text { evolves the argument of his rifacimento of } \\
\text { the second Eclogue: "Esta egloga, en la } \\
\text { qual Garcilaso dela Vega pone un pastor } \\
\text { llamado Albanio, aqui se llama Silvano } \\
\text { (Córdova's grammar is as erratic as his } \\
\text { verse), por la parte sensual del hombre; y } \\
\text { donde alla se llama otro pastor Salicio, } \\
\text { aqui se llama Racinio, por la razon; y } \\
\text { la pastora que alla le dize Camila, aqui se } \\
\text { llama Celia, que es el alma; y el pastor } \\
\text { Nemoroso se llama aqui Gracioso, por la } \\
\text { gracia, con cuya fuerça el hombre vence a } \\
\text { si mismo. Y en la ficcion do alaba Gar- } \\
\text { cilasso la succession de los duques de Alba, } \\
\text { aqui se ponen algunos patriarchas y reyes } \\
\text { de la generacion de Jesu Christo, Redemp- } \\
\text { tor Nuestro, quanto a su sacratissima } \\
\text { humanidad, sin declarar nombre, ecepto el } \\
\text { del bien aventurado Sant Joseph, que } \\
\text { se pone aqui en lugar de Severo, el viejo } \\
\text { tan señalado y alabado por el dicho Gar- } \\
\text { cilasso, y todo para en alabança de Jesu } \\
\text { Christo, Dios y hombre verdadero." } 1 \\
\text { In the third Eclogue the nymphs are } \\
\text { none other than Prudence, Fortitude, Jus- }\end{array}$ \\
\hline & H I S P A I C NOTES \\
\hline
\end{tabular}




\section{LIFE A N D W OR K}

tice and Temperance, who disport themselves on the banks of the Jordan and give ear to the songs in praise of the Virgin, sung by Phelisio and Charino. It is amusing to read in Córdova's Elegy addressed to Luis de Vera, that Boscán's Leandro has cost him great effort, and not less diverting to hear in his Epistola in blank verse. of the ravages which the reading of Garcilaso's amorous verse inflicted on his innocent spirit. ${ }^{1}$ We find it hard to understand to-day the extravagance and bac taste which gave birth to such a monstruous misunderstanding; that it was not limited to Sebastián de Córdova seems clear from the fact that his edition "a lo divino" was reprinted two years later.

In the same vein of horror for beauty, Juan López de Úbeda writes in the Preface to his Vergel de flores divinas $\left(\mathrm{I}_{5} 82\right.$ ) that the only trace which the works of Boscán, Garcilaso, or Castillejo will leave in the world is " that left by the passage of a snake upon the road or a bird in the air." He goes on to speak with much unction of

\section{A N D MONOGRAPHS}




\begin{tabular}{|c|c|}
\hline 406 & GARCILASO DE LA VEGA \\
\hline & $\begin{array}{l}\text { their ultimate repentance, citing as ex- } \\
\text { amples the Conversion of Boscán and an } \\
\text { "Elegy to the Soul" by Garcilaso. Even } \\
\text { more perturbed by the evil influence of } \\
\text { these pagan writers was the mystic Pedro } \\
\text { Malón de Chaide. In the Preface to his } \\
\text { Conversion de la Magdalena (I 593), he thun- } \\
\text { ders against the "Dianas, Boscáns, Garci- } \\
\text { lasos and Amadises," querying, "How can } \\
\text { a man who has wasted his hours on Garci- } \\
\text { laso withdraw within himself to think an } \\
\text { hour of God ?" and ending with the sug- } \\
\text { gestion that parents should burn such } \\
\text { books in their children's hands. }{ }^{1} \text { Happily } \\
\text { both López de Úbeda and Malón de Chaide } \\
\text { contented themselves with these protests } \\
\text { against the works of the poets of the past, } \\
\text { without attempting to maim them in the } \\
\text { style of Sebastián de Córdova. } \\
\text { Their example of restraint was not fol- } \\
\text { lowed, however, by a certain Juan de Ando- } \\
\text { silla Larramendi, who printed in I6 } 628 \text { a } \\
\text { little volume intitled, "Cristo Nuestro } \\
\text { Señor en la Cruz, hallado en los versos de } \\
\text { Garcilaso." The remainder of the title }\end{array}$ \\
\hline & H I S P N I C NOTES \\
\hline
\end{tabular}




\section{LIFE A N D WORK S}

shows his methods, for these verses were "sacados de diferentes partes y unidos con ley de centones." Such a patchwork was no slight task, as Fray Juan de la Plata remarked several years later in his Aprobación of a similar operation performed by one Angulo $y$ Pulgar on the works of Góngora. But the same critic further observed that, though Andosilla had done his work painstakingly and ingeniously, the result is rough and harsh to the ear, the more so because it is in blank verse which is so little fitted for Castilian art. ${ }^{1}$

The work of Andosilla was almost a coup de grâce for Garcilaso. In I622 Tamayo de Vargas, a learned Toledan, had published a new annotated edition of the poems of his fellowtownsman, deriving his material largely from Sánchez and Herrera, although he did have access to a manuscript of the Escorial, once the property of Diego de Mendoza, to assist him in the establishment of his text. This edition was the last printed in Spain for nearly one hundred and fifty years, unless we count the

\section{A N D MONOGRAPH S}




\begin{tabular}{|c|c|}
\hline 408 & GARCILASO DE LA VEGA \\
\hline • & $\begin{array}{l}\text { two editions of Luis de Briceno, printed at } \\
\text { Lisbon in I6 } 66 \text { and I } 632 \text { and based on } \\
\text { Tamayo's text, as belonging to Spanish } \\
\text { territory. } \\
\text { Another phase of interest in the general } \\
\text { popularity of Garcilaso was the high esteem } \\
\text { in which he was held by all the great fig- } \\
\text { ures of the Golden Age. Cervantes, whose } \\
\text { literary judgment was, it is true, far from } \\
\text { infallible, if we may judge by the praises } \\
\text { scattered through his Canto de Calliope or } \\
\text { the Viaje del Parnaso, echoed Herrera's } \\
\text { title and ardent praise of Garcilaso. } \\
\text { Throughout his works, particularly in the } \\
\text { Second Part of the Quixote, there are fre- } \\
\text { quent reminiscences cf his pcetry, some- } \\
\text { times half-unconscious repetitions of his } \\
\text { phraseology, sometimes actual quotations. } \\
\text { One of the most striking of his allusions is } \\
\text { the passage in Book LVII of the Second } \\
\text { Part in which Don Quixote and Sancho } \\
\text { come upon a group of merry-makers play- } \\
\text { ing two eclogues, one of which is the Second } \\
\text { Eclogue of our poet. Finally at the close } \\
\text { of his Adjunta al Parnaso he names Gar- }\end{array}$ \\
\hline & H I S P N I C NOTES \\
\hline
\end{tabular}




\section{I F E A N D W R K}

cilaso as one of the poets who have won the title of "El Divino."

To Lope de Vega as well, Garcilaso is "El Divino" and in all his works "The Phoenix" manifests the most ardent admiration for the Toledan poet, counting him at once as the initiator of the new school and the supreme example of that good taste which was so rapidly falling into disrepute. In the Papel de la nueva poesía, he cites Garcilaso and Herrera as the noblest models for imitation which Spanish literature offers. And again in the famous sonnet "A la nueva lengua" of the cultos, Garcilaso and Boscán represent the sound old Castilian tradition, amazed and dumbfounded at the jargon of the cultos, fancying that they are still in Vizcaya. The Laurel de Apolo is sprinkled with references to Garcilaso, who appears always as the recognized master of the poets of Spain,

que nadie el principado de aquella edad le niega.

\section{A N D MONOGRAPH S}




\begin{tabular}{|c|c|}
\hline 410 & GARCILASO DE LA VEGA \\
\hline & $\begin{array}{l}\text { Lope was too national a spirit to scorn the } \\
\text { native Castilian measures; in several pas- } \\
\text { sages, he expressly defends them from the } \\
\text { charge of inferiority to the versos largos of } \\
\text { Italy but he saw plainly what a service } \\
\text { Boscán and Garcilaso had performed in } \\
\text { enriching the treasure of Spanish verse } \\
\text { and he himself is perhaps the best example } \\
\text { of the free and masterly employment of } \\
\text { both types. } \\
\text { Of the other leading figures of the Golden } \\
\text { Age, we need cite only a few who testified } \\
\text { to their admiration for Garcilaso. Que- } \\
\text { vedo, like Lope de Vega, looked upon Gar- } \\
\text { cilaso as the best antidote for the excesses } \\
\text { of the cultos, } \\
\text { mientras por preservar nuestros Pegasos } \\
\text { del mal olor de culta gerigonza, } \\
\text { quemamos por pastillas Garcilasos. } \\
\text { In the same vein, "El Gran Tacaño" gives } \\
\text { as one of the titles which fit him to become } \\
\text { a writer of satisfactory comedies the fact } \\
\text { that "he had read Garcilaso." }\end{array}$ \\
\hline & H I P A N I NOTES \\
\hline
\end{tabular}




\section{I F E A N D WORK S}

It is doubly interesting to find that Góngora, the leader of the school of culteranismo, regarded him with no less admiration than the opponents of the school, as he shows in his cancion "Al sepulcro de Garcilaso de la Vega,"

Piadoso oy zelo culto, sino el hecho de artifice elegante, de marmol espirante, un generoso anima y otro buito, aqui donde entre jaspes $y$ entre oro talamo es mudo, tumulo canoro. Aqui donde coloca justo afecto en aguja no eminente sino en urna decente esplendor mucho si ceniza poca, bienque milagros despreciando Egipcios pira es suya este monte de edificios. Si tu passo no enfrena, tan bella en marmol copia, io caminante! essa es la ya sonante emula de las trompas, ruda avena, a quien del Tajo deben oy las flores el dulce lamentar de dos pastores.

Este el curvo instrumento que el Albano canto, segundo Marte,

\section{A N D M O NOGRAPH S}




\begin{tabular}{|c|c|}
\hline 412 & GARCILASO DE LA VEGA \\
\hline & $\begin{array}{l}\text { de sublime ya parte } \\
\text { pendiente quando no pulsarlo al viento } \\
\text { solicitarlo oyo silva confusa, } \\
\text { ya a docta sombra, ya a invisible Musa, } \\
\text { vestido pues el pecho } \\
\text { tunica Apolo de diamante gruessa. } \\
\text { Parte la dura guessa, } \\
\text { con la que en dulce laço el blando lecho, } \\
\text { si otra inscripcion deseas, vete zedo: } \\
\text { lamina es qualquier piedra de Toledo. } \\
\text { Góngora's enthusiasm for the Toledan } \\
\text { poet is not, after all, surprising. There is } \\
\text { nothing in his canon of art which is funda- } \\
\text { mentally opposed to that of his predecessor; } \\
\text { his methods of composition are not es- } \\
\text { sentially different. It is rather the contrast } \\
\text { between Garcilaso's simple good taste and } \\
\text { Góngora's complicated bad taste which } \\
\text { sets them at the two extremes of style. } \\
\text { It was the development of this trend of } \\
\text { bad taste which led to the neglect of Gar- } \\
\text { cilaso's works in the late seventeenth and } \\
\text { early eighteenth centuries. Although the } \\
\text { preceptists, like Jiménez Patón in his Mer- } \\
\text { curius trimegistus ( } 62 \text { I } \text { ) or Lorenzo Gra- }\end{array}$ \\
\hline & H I P A N I NOTES \\
\hline
\end{tabular}




\section{I F E A N W O R K S}

cián in his Agudeza y arte de ingenio (1648), frequently cited verses of Garcilaso as models of good form, ${ }^{1}$ their influence was of little avail; Garcilaso was well-nigh forgotten.

With the revival of good taste which is marked by the introduction of the French school in the eighteenth century, Garcilaso once more became a theme of interest. Luzán, in his essay, La poética, is most eulogistic in his estimate, declaring that a single one of the sonnets of Garcilaso is more to be esteemed than all the conceits and affectation of Góngora or the other poets of his ilk. ${ }^{2}$ Velázquez, too, in his Origenes de la poesia castellana (I754) is equally laudatory. ${ }^{3}$ This renewal of interest culminated in the publication of an excellent edition of his poems in $I_{7} 6_{5}$, prepared by the distinguished diplomat and scholar, José Nicolás de Azara. Not only was this edition followed by a steady succession of reprints, some of them, issued from the press of Sancha, undoubtedly directed by José Antonio Pellicer, but also

\section{A N D MONOGRAPH S}




\begin{tabular}{|c|c|}
\hline 414 & GARCILASO DE LA VEGA \\
\hline & $\begin{array}{l}\text { a large place was given to his verses in the } \\
\text { numerous anthologies of the time, begin- } \\
\text { ning with the Parnaso español and ending } \\
\text { with Quintana's Poesias selectas castellanas. } \\
\text { Garcilaso was once more regarded as a } \\
\text { representative of the good taste in liter- } \\
\text { ature which had led Lope de Vega so often } \\
\text { to turn to his example for arguments } \\
\text { against the culteranos. So, in La derrota } \\
\text { de los pedant s of the younger Moratin, he } \\
\text { is the commander of the right wing of the } \\
\text { cohorts of Apollo and is wounded and } \\
\text { driven from the field of battle by a terrific } \\
\text { blow on the chest from the Macabeo of } \\
\text { Silveira, which has already struck Bara- } \\
\text { hona de Sota in passing. }{ }^{1} \text { This esteem for } \\
\text { him continues in the early years of the } \\
\text { nineteenth century. Gallego wrote an ex- } \\
\text { cellent sonnet in I } 807 \text {, "A la memoria de } \\
\text { Garcilaso". and in the same year Quintana } \\
\text { published his first edition of Poesias selec- } \\
\text { tas castellanas, containing numerous com- } \\
\text { positions by him. In his Introduction, } \\
\text { Quintana studies the work of Garcilaso, } \\
\text { answering the charge that he lacked origin- }\end{array}$ \\
\hline & H I P A N I NOTES \\
\hline
\end{tabular}




\section{I F E A N D W O R K}

ality and commenting on his mastery of form and the purity of his language. His final dictum is that "Garcilaso is, if not the greatest Castilian poet, at least the most classic, the poet who has enjoyed the widest popularity, whose reputation has been least questioned and who probably will not perish as long as there is a Castilian language and Castilian poetry."

Echoes of this same enthusiasm are to be found in the Anotaciones a la Poética of Martínez de la Rosa, who constantly turns to Garcilaso as the great master of Spanish versification, calling him "el más dulce de nuestros poetas.", As late as I 844 we find Lista defending Garcilaso and the others poets of the sixteenth century from the charge of being merely imitators, which had been made against them in an article in the Liceo español. ${ }^{3}$ With his eminently classical turn of mind, Lista goes so far as to say that "Garcilaso is so profoundly tender, so highly original in the song of Nemoroso, because in the song of Salicio he imitated Virgil with such per-

\section{A N D MONOGRAPHS}




\begin{tabular}{|l|l|}
\hline 416 & $\begin{array}{l}\text { GARCILASO DE LA VEGA } \\
\text { fection." But in general, the period from } \\
\text { I } 830 \text { to I } 850 \text { showed little interest in Gar- } \\
\text { cilaso. The Romantic school was more } \\
\text { fascinated with mediaeval legends than } \\
\text { with the loves of shepherds. There was } \\
\text { no edition of Garcilaso printed between } \\
\text { I828 and I 86o. } \\
\text { In I85o there appeared the first scholarly } \\
\text { life of Garcilaso by Eustaquio Fernández } \\
\text { de Navarrete, based on documents com- } \\
\text { piled by his illustrious father. Navarrete's } \\
\text { criterion was not always sound; he too } \\
\text { often accepts traditional statements as of } \\
\text { the same value as the documents he pub- } \\
\text { lished. But his work added greatly to our } \\
\text { knowledge of the poet and made clear a } \\
\text { number of doubtful episodes in his life. } \\
\text { Since the publication of his work, interest } \\
\text { in the poet has been unflagging, revealed } \\
\text { in such widely divergent criticisms as that } \\
\text { of Manuel Cañete, read before the Acad- } \\
\text { emy in I858, and that of Azorin in his } \\
\text { essay on Garcilaso and Góngora, published } \\
\text { in his Lecturas españolas in I9I } 2 . \text { To } \\
\text { Cañete, Garcilaso's poetry fails of its full }\end{array}$ \\
\hline H I S P A N I C N O T E S \\
\hline
\end{tabular}




\section{LIFE A N D W O R K S}

effect because of its pagan neglect of Christianity; his indifference to Nature is one of the defects of his generation. To Azorín, it is precisely his intimate sensation of natural beauty which, added to his perfection of form, gives his work its greatest charm.

Not only have critics concerned themselves with his work, but scholars as well have contributed to our knowledge of the man and his writings by frequent investigations or by the publication of documents. It is to be regretted that the late Menéndez y Pelayo did not live to complete his study of the poet, for which he had already gathered the materials. His broad reading and his sensitive taste, particularly for the beauties of classic art, would have made his work of inestimable value. The volume in the Antologia, which he was to have contributed, has since been written by Sr. José Rogerio Sánchez. It is plainly an improvisation. These last years have witnessed the publication of at least four editions of his poems in popular

\section{A N D MONOGRAPHS}




\begin{tabular}{|c|c|}
\hline 418 & GARCILASO DE LA VEGA \\
\hline & $\begin{array}{l}\text { editions of the Castilian classics. Gar- } \\
\text { cilaso is not merely one of the great names } \\
\text { in the national literature of Spain; he is } \\
\text { still a source of delight to all who read } \\
\text { Spanish. } \\
\text { In a country as devoted to the drama as } \\
\text { Spain, it is not surprising that the brief, } \\
\text { romantic life of the poet was made a theme } \\
\text { for the theatre. Already in the Carlos } V \\
\text { en Francia of Lope de Vega, Garcilaso ap- } \\
\text { pears as one of the courtiers with an insig- } \\
\text { nificant rôle. In the British Museum there } \\
\text { exists an unpublished comedia, intitled } \\
\text { "Garcilaso enamorado; amores, versos y } \\
\text { muerte." The manuscript is dated Madrid, } \\
\text { September } 20 \text {, I6r } 8 \text { and is signed Diego } \\
\text { Seron Spinossa, but no information seems } \\
\text { available as to the author or the presenta- } \\
\text { tion of the play. The plot, briefly summed } \\
\text { up, tells of Garcilaso's love for Doña María } \\
\text { and his neglect of his former mistress, a } \\
\text { French lady, Doña Porcia. Hearing of } \\
\text { Doña María's approaching marriage, he } \\
\text { raves in the garden in verses which once } \\
\text { Salicio had sung, and then starts for the }\end{array}$ \\
\hline & H I S A N I C NOTES \\
\hline
\end{tabular}




\section{I F E A D W O R K}

wars, where he is wounded in the arms and mouth, so that he can say only, "Ba! Ba!" After Doña María's marriage he once more returns to the field of battle. There he learns from Doña Porcia of Donia Maria's death and enters the fray, to fall in death at the foot of the tower. Artistically the play, which introduces a galaxy of notables, including Charles $V$, Sclyman the Magnificent, Barbarrosa, Antonio de Leiva, the Duke of Alba, Boscán and Diego de Mendoza, is quite negligible. Its only interest depends upon its use of the poet's own verses, which are introduced, more or less $\grave{a}$ propos, throughout the entire work.

Once more, in the nineteenth century, we find the story of the poet used as the subject of a play in the "Garcilaso de la Vega" ( 840 ) of Gregorio Romero y Larrañaga. Here the plot is wholly fantastic, adorned with all the devises of intrigue and surprise which the vagaries of the type tolerated. The scene is laid in Bologna in I 530; Garcilaso's love for the Duchess of Lérida ends in a sentence of exile to the

\section{A N D MONOGRAPH S}




\begin{tabular}{|c|c|}
\hline 420 & GARCILASO DE LA VEGA \\
\hline & $\begin{array}{l}\text { Danube. One of the most amusing scenes } \\
\text { is that in which Garcilaso is hailed as } \\
\text { "Father of the Castilian Language" and } \\
\text { crowned "King of Poets" by a group of } \\
\text { contempcrary poets including Cristóbal } \\
\text { de Castillejo! There is no intrinsic merit } \\
\text { in either of these dramatic works, yet they } \\
\text { point once more to the permanent and wide- } \\
\text { spread cult oc Garcilaso as one of the na- } \\
\text { tion's glories. } \\
\text { Outside of Spain, Italy was naturally the } \\
\text { first country to recognize the fame of Gar- } \\
\text { cilaso. The occasional references to him } \\
\text { by his contemporaries in Italy we have } \\
\text { already mentioned, in discussing his life. } \\
\text { After his death, he was still remembered. } \\
\text { Tansillo, who had addressed two of his } \\
\text { sonnets to him, used his first Eclogue in } \\
\text { writing his Canzone VII and another mem- } \\
\text { ber of the Neapolitan school, the poetess, } \\
\text { Laura Terracina, is said by Herrera to have } \\
\text { applied to him as an epitaph, a stanza of } \\
\text { the Orlando furioso, } \\
\text { Un giovinetto che col dolce canto, } \\
\text { concorde al suon de la cornuta cetra, }\end{array}$ \\
\hline & H I P A N I C NOTES \\
\hline
\end{tabular}




\section{LIFE A N D W O R K S}

d'intenerire un cor si dava vanto, ancor che fosse piu duro che pietra. Felice lui, se contentar di tanto onor sapeasi, e scudo, arco e faretra aver in odio, e scimitarra e lancia, che lo fecer morir giovine in Francia.

(XVI, 72)

At the end of his Elogia doctorum virorum (1550), Paolo Giovio added a brief note on the scholars of other countries and there he mentions Garcilaso as one of the first in Spain to pursue learning, praising his Latin odes for their Horatian suavity and recounting his untimely death in France. ${ }^{1}$ Two years later Antonfrancesco Doni included in his Pistolotti amorosi an almost verbatim translation of Garcilaso's Sonnet XXIX,

Passando il mar Leandro coraggioso, in amoroso fuoco tutto ardendo,

stating that it was translated from the Spanish but without naming the author. ${ }^{2}$

Tansillo was not the only author of the Cinquecento who found inspiration in the poet's first Eclogue. Ludovico Paterno in

\section{A N D M O NOG R P H S}




\begin{tabular}{|c|c|}
\hline 422 & GARCILASO DE LA VEGA \\
\hline & $\begin{array}{l}\text { the third of the Egloghe amorose, printed } \\
\text { in his Nuove fiamme (I } 568)^{1} \text { paraphrased } \\
\text { the laments of both Salicio and Nemoroso } \\
\text { in pedestrian versi sciolti, thinking the } \\
\text { Spanish poet not unworthy of a place be- } \\
\text { side Petrarch, his normal model. In the } \\
\text { following century, the chief representative } \\
\text { of the Italian form of Gongorism, Giam- } \\
\text { battista Marino, accorded to Garcilaso a } \\
\text { portrait among the pitture of La galeria } \\
\text { (I620), } \\
\text { Del poetico giorno } \\
\text { aperse al clima Ispano i primi albori } \\
\text { il raggio mattutin de' miei splendori; } \\
\text { hor se l'occaso suo rendere adorno } \\
\text { può di luce immortale, } \\
\text { aurora occidentale } \\
\text { ornare il nome de la patria mia } \\
\text { lucifero e non Hespero devria. }\end{array}$ \\
\hline & H I S P N I C NOTES \\
\hline
\end{tabular}




\section{LIFE A N D WORK S}

tion from the poet's Canción IV, in his treatise Della perfetta poesia, ( 1706$),{ }^{1}$ there was no general knowledge of the Castilian writer during the eighteenth century until the period of the prolonged quarrel between Bettinelli and Tiraboschi and their followers on one hand and Lampillas and his coterie on the other, over the responsibility for the origin of bad taste in European letters.

An Italian, Giambattista Conti, resident in Madrid, published there in 1773 a translation into Italian of the first Eclogue, and in his subsequent Scelta di poesie castigliane (I782-90) devoted the whole of the second volume to translations of his works. Lampillas, as might be expected, was an ardent enthusiast over Garcilaso's genius. ${ }^{2}$ Another Italian of the same period, Gianfrancesco Masdeu, - he may be regarded as an Italian in spite of his Catalan birth, - author of the Historia critica de España y de la cultura española, also produced an anthology of translations from the Spanish, vying with that of Conti, in

\section{A N D MONOGRAPHS}




\begin{tabular}{|c|c|}
\hline 424 & GARCILASO DE LA VEGA \\
\hline & $\begin{array}{l}\text { which a considerable place is accorded to } \\
\text { Garcilaso. } \\
\text { This current of interest in our poet, } \\
\text { stagnant during most of the nineteenth } \\
\text { century, has recently been renewed by } \\
\text { several scholars in Naples, where the poet } \\
\text { spent the most creative years of his life. } \\
\text { In particular the researches of Signor } \\
\text { Benedetto Croce, the distinguished philos- } \\
\text { opher, and of Signor Eugenio Mele have } \\
\text { added in no small measure to our knowl- } \\
\text { edge of the life and the literary activity of } \\
\text { Garcilaso. } \\
\text { We have seen the early influence which } \\
\text { Garcilaso exercised on the Portuguese } \\
\text { poet Sá de Miranda. His reputation was } \\
\text { known to other ports of the time as well, } \\
\text { such as Antonio Ferreira }{ }^{1} \text { or Diogo Ber- } \\
\text { nardes, who celebrated his fame, along } \\
\text { with that of Boscán, as the founder of the } \\
\text { new school. The tradition of interest in } \\
\text { his work is best illustrated in the lyrics of } \\
\text { the greatest of Portuguese poets, Luis de } \\
\text { Camões. Among his Rimas are to be } \\
\text { found not merely reminiscenses of the Cas- }\end{array}$ \\
\hline & H I P A N I NOTES \\
\hline
\end{tabular}




\section{IFE A N D WORK S}

tilian poet, but frequent imitations, adaptations, translations and even parodies. As an example of the skill with which he used his borrowed material it will suffice to quote his paraphrase of Garcilaso's Sonnet $\mathrm{XI}$ :

Moradoras gentis e delicadas do claro e aureo Tejo, que metidas estays em suas grutas escondidas, e com doce repouso sossegadas;

agora esteys de amores inflamadas, nos cristalinos Paços entretidas, agora no exercicio embevecidas das telas de ouro puro matizadas.

Movey dos lindos rostros a luz pura de vossos olhos bellos, consentindo que lagrimas derramen de tristura;

e assi com dor maes propia ireys ouvindo as quexas que derramo da ventura, que com penas de Amor me vay seguindo. ${ }^{1}$

In form as well he is indebted to him whom he calls "o brando e doce Lasso." Thus he employs the Spaniard's lira in his third Ode and in his eclogues, which are polymetric he gives a Portuguese example of the inner rhyme. ${ }^{2}$

\section{A N D MONOGR A P H S}




\begin{tabular}{|c|c|}
\hline 426 & GARCILASO DE LA VEGA \\
\hline & $\begin{array}{l}\text { In the following century the reputation } \\
\text { of Garcilaso resisted the influx of the uni- } \\
\text { versal wave of bad taste. Even as par- } \\
\text { tisan a culterano as Francisco Manoel de } \\
\text { Mello begrudgingly acknowledges Garci- } \\
\text { laso's claim to the primacy in the Castilian } \\
\text { Parnassus in his Hospital das letras, first } \\
\text { printed in his Apologos dialogaes (I72I); } \\
\text { the other poets of the sixteenth century he } \\
\text { unhesitatingly assigns to Limbo. }{ }^{1} \text { Nor } \\
\text { should we forget the enthusiastic praise ac- } \\
\text { corded to him by the author of the ill- } \\
\text { digested commentary on Camones, Manoel } \\
\text { de Faria e Sousa. In Portugal, as in Spain, } \\
\text { Garcilaso's fame was unquestioned, uni- } \\
\text { versal. } \\
\text { Beyond the Pyrenees the earliest evi- } \\
\text { dence of acquaintance with his work is an } \\
\text { imitation of his second Eclogue, the Pas- } \\
\text { torale amoureuse (I } 569 \text { ) of François de Belle- } \\
\text { forest. }{ }^{2} \text { A decade later, the Protestant } \\
\text { poet, Guillaume de Saluste, seigneur du } \\
\text { Bartas, mentions Garcilaso among the lead- } \\
\text { ing men of letters in Spain in his religious } \\
\text { epic, La semaine (I } 579 \text { ), }\end{array}$ \\
\hline & H I S A N I C NOTES \\
\hline
\end{tabular}




\section{LIFE A N D WORKS}

Guevare, le Boscan, Grenade, et Garcilace, abreuvez du nectar qui rit dedans la tasse de Pitho verse-miel, portent le Castillan. ${ }^{1}$

But these early evidences of interest were not destined to be continued. As:de from a few passing mentions in such works as L'A pollon, ou l'oracle de la poésie italienne et espagnole (1644) of Bense-Dupuis ${ }^{2}$ or the Nouvelle méthode pour apprendre facilement la langue espagnole, found in Lancelot's Grammaire générale et raisonée (I660) ${ }^{3}$ the name of Garcilaso remained unknown until the nineteenth century. During the first decades of the last century a number of works contained discussions of his poetry; first in point of time was the little anonymous Essai sur la litterature espagnole, the work of Malmontel. Longer articles appeared in the French translation of Bouterwek (I8I3) or in Sismondi's De la littérature du midi de l'Europe (I8I3). Finally France received an opportunity to study his works at first hand through the editions printed at Paris in $I_{1} I_{7}$ and $I 82 \mathrm{I}$ and also through the translations into

\section{A N D MONOGRAPH S}




\begin{tabular}{|c|c|}
\hline 428 & GARCILASO DE LA VEGA \\
\hline & $\begin{array}{l}\text { French by the Malagan poet, Juan Maria } \\
\text { Maury (I } 826 \text { ). } \\
\text { Of the many critics and scholars who } \\
\text { have turned their attention to Garcilaso } \\
\text { in more modern times special mention } \\
\text { need be made of only two: the enthusiastic } \\
\text { criticism of his poems in the Histoire com- } \\
\text { parée des littératures espagnole et fraņ̧aise } \\
\text { (I } 843 \text { ) of Puibusque and the admirable } \\
\text { study of his work in the Histoire de la } \\
\text { poésie espagnole of the Belgian scholar, } \\
\text { Ferdinand Loise. } \\
\text { The northern countries of Europe offer } \\
\text { a much slighter acquaintance with Gar- } \\
\text { cilaso, as might be expected. In Germany } \\
\text { the only mention of his work until the } \\
\text { eighteenth century is the brief article on } \\
\text { him in Andreas Schott's Hispaniae biblio- } \\
\text { theca, printed at Frankfurt in I6o8; and } \\
\text { Schott was a Fleming. During the latter } \\
\text { half of the eighteenth century there was a } \\
\text { real wave of interest in Hispanic studies } \\
\text { in Germany, with its centre at Göttingen. } \\
\text { In I } 769 \text { Dieze in his excellent translation } \\
\text { of the Origenes de la poesia castellana of }\end{array}$ \\
\hline & H I PANIC NOTES \\
\hline
\end{tabular}




\section{LIFE A N D WORK S}

Velázquez devoted a large attention to the work of Garcilaso and thirty-five years later another professor of the same university, Friedrich Bouterwek, produced the first history of Spanish literature, the "Geschichte der spanischen Poesie and Beredsamkeit" (I 804 ). Bouterwek's opinions are colorless, and the space which he dedicates to the study of the life and works of Garcilaso is small in proportion to that which he gives Boscán, or Diego de Mendoza, for example. As Menéndez y Pelayo has justly remarked, the northern critics, who read with their eyes rather than listen to the verse with their ears, have always shown a greater charity toward Boscán than have his own people. One other sign of acquaintance with Garcilaso which concerns Germany must be mentioned: the few examples of his verse which were printed in the Floresta de rimas antiguas castellanas of Johann Nicholas Bōhl von Faber, unless we prefer to call him Juan Nicolás and count him among the Spaniards, with whom his own literary

\section{A N D MONOGRAPH S}




\begin{tabular}{|c|c|}
\hline 430 & GARCILASO DE LA VEGA \\
\hline & $\begin{array}{l}\text { activity as well as that of his daughter, } \\
\text { Fernán Caballero, is inseparably connected. } \\
\text { It is probable that Garcilaso was un- } \\
\text { known in England before the appearance } \\
\text { of the Arcadian Rhetorike (I } 588 \text { ) of } \\
\text { Abraham Fraunce, unless it be that a pas- } \\
\text { sage in the sixth eclogue of the Eglogs, } \\
\text { Epytaphes and Sonnettes (I } 63 \text { ) of Barnaby } \\
\text { Googe is an imitation of a scene in his } \\
\text { second Eclogue. Fraunce cites in all forty } \\
\text { lines of Garcilaso, with one exception } \\
\text { drawn from the Eclogues. It seems prob- } \\
\text { able that he was led to his acquaintance } \\
\text { with the work of the Spanish poet by his } \\
\text { reading of La Semaine of du Bartas, for } \\
\text { all the examples which he cites from } \\
\text { foreign authors are from poets mentioned } \\
\text { by the French writer. It is interesting to } \\
\text { find that he too regarded Boscán as the } \\
\text { more important poet, if we may judge } \\
\text { again by numbers, for he cites over two } \\
\text { hundred of his verses. }{ }^{1} \\
\text { As in France, this early evidence of a } \\
\text { knowledge of Garcilaso's poems remained } \\
\text { isolated until the beginning of the last }\end{array}$ \\
\hline & H I S A N IC NOTES \\
\hline
\end{tabular}




\section{LIFE A N D WORK S}

century. In I 800 an Italian, Gaetano Ravizzotti, published at Romney an anthology of Castilian poetry, containing the three Eclogues of Garcilaso and five of his lyrics, with a brief life of the poet. Undoubtedly from this collection Horace Walpole made his translation of a part of the first Eclogue and a sonnet (No. XXIII) which he published anonymously at Cambridge in I805, under the title Isabel, from the Spanish of Garcilaso de la V'ega, with other poems and translations from the Greek, Italian, etc. The next work which treats of him is Lord Holland's "Life of Lope de Vega" ( $18 \mathrm{I} 7$ ), in which there is a brief mention of his verses and a translation of one of his poorer sonnets (No. XXXIV). ${ }^{1}$ Passing over the little Essay on Spanish Literature (1818) of Anaya, we come to two publications of interest in 1823 : the English translation of Bouterwek and more important for us, the translation of Garcilaso's poems by J. H. Wiffen. Wiffen prefaced his work by a long and romanticly inaccurate"life" of the poet and a free adap-

\section{A N D MONOGRAPHS}




\begin{tabular}{|c|c|}
\hline 432 & GARCILASO DE LA VEGA \\
\hline & $\begin{array}{l}\text { tation of Quintana's Introduction on } \\
\text { Spanish poetry. His translations are close, } \\
\text { often too close, but as a whole they leave } \\
\text { but a vague impression of the music of } \\
\text { the original. No two languages are more } \\
\text { fundamentally different in natural qualities } \\
\text { than English and Spanish. The attempt } \\
\text { to reproduce in English the tender grace- } \\
\text { fulness of Garcilaso's verse must inevitably } \\
\text { lead to a style that to us sounds sentimental } \\
\text { and even "namby-pamby." Even at his } \\
\text { best this is the weakness of Wiffen's ver- } \\
\text { sions; witness the following stanza: } \\
\text { Here ceased the youth his Doric madrigal, } \\
\text { And sighing, with his last laments let fall } \\
\text { A shower of tears; the solemn mountains } \\
\text { round, } \\
\text { Indulgent of his sorrow, tossed the sound } \\
\text { Melodious from romantic steep to steep, } \\
\text { In mild responses deep; } \\
\text { Sweet Echo, starting from her couch of moss, } \\
\text { Lengthened the dirge, and tenderest Philomel, } \\
\text { As pierced with grief and pity at his loss, } \\
\text { Warbled divine reply, nor seemed to trill } \\
\text { Less than Jove's nectar from her mournfulbill. } \\
\text { What Nemoroso sang in sequel, tell }\end{array}$ \\
\hline & H I P A N I NOTES \\
\hline
\end{tabular}




\section{LIFE A N D WORK S}

\section{3}

Ye, sweet-voiced Sirens of the sacred hill!

Too high the strain, too weak my groveling reed,

For me to dare proceed.

The rest of the nineteenth century saw no striking proofs of an interest in Garcilaso in England, except in the sound criticism of Mr. James Fitzmaurice-Kelly as it appears in his History of Spanish Literature. But in the New World of English speech, one scholar at least has given attention to the story of the life and work of the Spanish poet, that is George Ticknor. The care with which Ticknor read his verses is made plain by the copious marginal notes which he pencilled in his personal copy of the poems. ${ }^{1}$ His discussion of Garcilaso in his History of Spanish Literature is penetrating and just; his brief translations of passages from the first Eclogue, done in blank verse, are infinitely more satisfactory than those of Wiffen. We cannot end with a more fitting summary of Garcilaso's place in the literature of Spain than his statement: "Garcilaso has come

\section{A N D MONOGRAPHS}




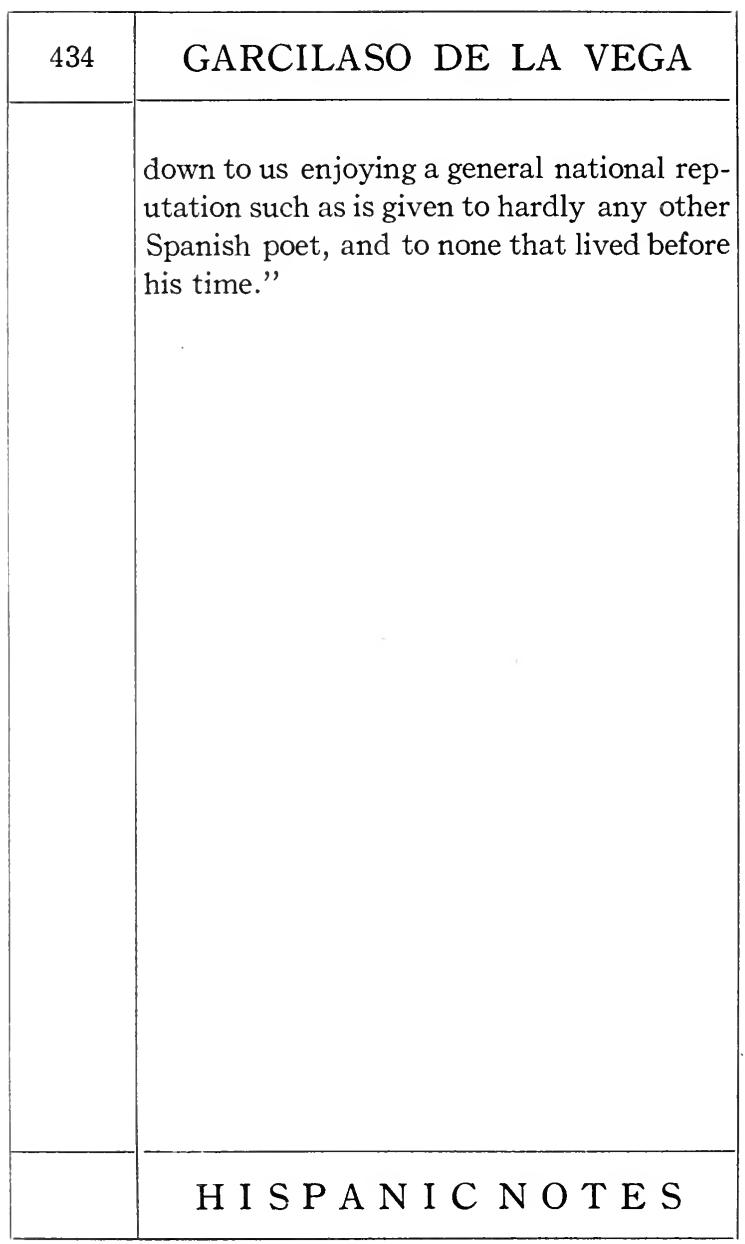




\section{LIFE A N D W ORK S}

\section{APPENDIX A}

PRUEBA DE NOBLEZA DE GARCILASO DE LA VEGA.

(Archivo histórico nacional. Ordenes militares. Santiago. Garcilaso de la Vega y de Guzmán.

Toledo, 1523. No. 8613.)

Garcia Laso de la Vega. En Burgos a xi de Setiembre de MDxxiij años.

Pero Abrera, vezino de la çibdad de Cordoba testigo presentado para la dicha ynformaçion, abiendo jurado en forma de derecho, dixo lo siguiente:

A la primera pregunta, dixo que conosçe a el dicho Garcia Laso de la Vega e que sera de hedad de veynte e çinco años, poco mas o menos. e ques natural de la çibdad de Toledo e que hes hijo legitimo de don Garcia Laso de la Vega, comendador mayor que fue de Leon e señor de Batres e Cuerva, e de Sancha de Guzman su muger, a los quales este testigo conosçio. Fue preguntado sy conosçio al padre e a la madre

\section{A N D MONOGRAPHS}




\begin{tabular}{|c|c|}
\hline 436 & GARCILASO DE LA VEGA \\
\hline & $\begin{array}{l}\text { del dicho don Garcia Laso de la Vega e al } \\
\text { padre e a la madre de la dicha doña Sancha, } \\
\text { padre e madre del dicho Garcia Laso } \\
\text { de la Vega; dixo que conosçio a Pero } \\
\text { Suarez de Figueroa e a doña Blanca su } \\
\text { muger, padre e madre del dicho don } \\
\text { Garcia Laso de la Vega, el qual dicho Pero } \\
\text { Suarez hera hermano del conde de Feria } \\
\text { viejo e que al padre a la madre de la dicha } \\
\text { doña Sancha no los conosçio, mas de los } \\
\text { oyr dezir e que el padre de la dicha doña } \\
\text { Sancha se llamava [blank] de Guzman, } \\
\text { señor de Batres e de otros vasallos e que } \\
\text { la muger del dicho [blank] de Guzman no } \\
\text { sabe como se llamava, mas de oyr dezir } \\
\text { que hera de muy buen linaje. Fue pre- } \\
\text { guntado sy hes pariente del dicho Garcia } \\
\text { Laso. Dixo que no, e que sera de hedad } \\
\text { de lx años. } \\
\text { A la segunda pregunta, dixo que sabe y } \\
\text { hes publico e notorio que el dicho don } \\
\text { Garcia Laso de la Vega e los dichos don } \\
\text { Garcia Laso de la Vega e doña Sancha de } \\
\text { Guzman su muger, padre e madre del } \\
\text { dicho Garcia Laso, e los dichos sus avuelos }\end{array}$ \\
\hline & H.ISPANIC NOTES \\
\hline
\end{tabular}




\section{LIFE A N D W O R K}

e avuelas fueron e son avidos e tenidos e comunmente rreputados por honbres hijosdalgo e de linpia e noble sangre, syn yntervenir rraça ninguna de converso ni moro ni de otra cosa, e por tales este testigo los tuvo e tiene.

A la tercera pregunta, dixo que sabe que el dicho Garcia Laso tiene cevales e cavallos e los puede bien tener.

A la quarta pregunta, dixo que no sabe que el dicho Garcia Laso aya sido rrieptado e que si lo oviera seydo, este testigo lo oviera sabido o oydo e questo sabe del caso. E firmolo de su nombre. Pero Abrera.

\section{A N D MONOGRAP H S}




\begin{tabular}{|c|c|}
\hline 438 & GARCILASO DE LA VEGA \\
\hline & $\begin{array}{l}\text { APPENDIX B } \\
\text { LETTER OF DEDICATION FROM SCIPIONE } \\
\text { CAPECE TO GARCILASO } \\
\text { (Donati in libros duodecim Aeneidos quae antea deside- } \\
\text { rabatur absoluta interpretatio. Impressum Neapoli per } \\
\text { Ioannem Sulzbacchium \& Matthiam Cancer quarto Idus } \\
\text { Novembris Anno Domini M. D. XXXV. f. [2] vo.) } \\
\text { Scipio Capycius Garcilasso viro clariss. } \\
\text { S. } \\
\text { Donati comentarios in Virgilianam Aenei- } \\
\text { da, qui ex Pontani bibliotheca in manus } \\
\text { nostras devenerant, omnes quidem eruditi } \\
\text { mira cupiditate invulgandos impressione } \\
\text { semper expetiverunt. Postea vero quam } \\
\text { tu mihi, Garcilasse illustris atque doctis- } \\
\text { sime, id fieri suasisti, nihil cunctandum } \\
\text { in ea re censui, doctis omnibus ratus quam } \\
\text { maxime placiturum quod gravi tuo fuis- } \\
\text { set singularique iudicio probatum. Itaque } \\
\text { volumen ilico imprimendum tradidi tuo } \\
\text { iussu; curanteque Paulo Flavio erudito } \\
\text { iuvene tuique ac nostri studiosissimo brevi } \\
\text { absoluta impressio est, opere in multa } \\
\text { volumina ecscripto (!), ad communem } \\
\text { studiosorum omnium utilitatem ex tua } \\
\text { sententia. Vale. }\end{array}$ \\
\hline & H I S P A I C NOTES \\
\hline
\end{tabular}




\section{IFE A N D W OR K}

\section{LIST OF WORKS CONSULTED}

Abelson, Paul. The Seven Liberal Arts. New York, I906.

Albèri, Eugenio, ed. Relazioni degli ambasciatori veneti al Senato. Firenze, I839-55. I4 V.

Alonso Getino, Luis G. Vida y procesos del maestro Fr. Luis de León. Salamanca, 1907.

Amador de los Rios, Rodrigo. Santander. Barcelona, I891. (in España: sus monumentos y artes, etc.)

Antonio, Nicolás. Bibliotheca hispana nova. 2a ed. Matriti, I783-88. 2 v.

Argote de Molina, Gonzalo. Nobleza del Andaluzia. Sevilla, 1588.

Arustrong, Edward. The emperor Charles $\mathrm{V}$. London, 1902. $2 \mathrm{v}$.

Azara, José Nicolás DE, ed. Obras de Garcilaso de la Vega, ilustradas con notas. Madrid, 1765 .

Bernáldez, ANdrés. Historia de Fernando e Isabel. (in Rosell, Crónicas, etc., III, B. A. E., LXX)

\section{A N D MONOGRAPHS}




\begin{tabular}{|c|c|}
\hline 440 & GARCILASO DE LA VEGA \\
\hline & 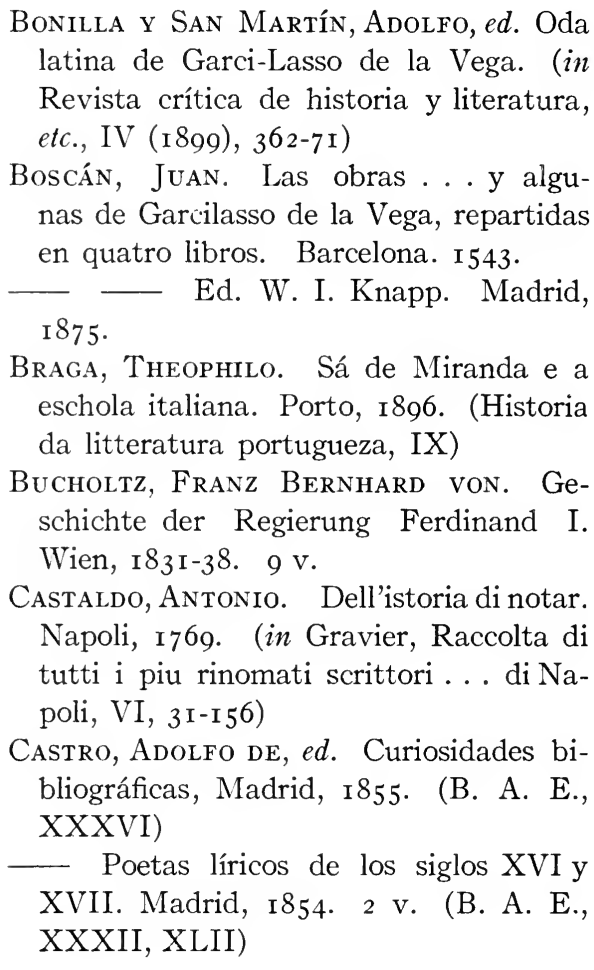 \\
\hline & H I P A N I NOTES \\
\hline
\end{tabular}




\section{LIFE A N D W R K S}

Catalina García, Juax. Ensayo de una tipografía complutense. Madrid, isSg.

Champolimon-Figeac, Aimé, ed. La captivité du roi François $\mathrm{I}^{\mathrm{er}}$. Paris, $18+7$.

(Doc. inéd. sur l'histoire de France)

Charrière, Ernest, ed. Négociations de la France dans le Levant. Paris, I8 8-6o. 4 v. (Doc. inéd. sur l'histoire de France) Cienfuegos, Álvaro. La heroyca vida, virtudes y milagros del grande $\mathrm{S}$. Francisco de Borja. Madrid, I7 7 .

Cremexcín, Diego. Elogio de la Reina Católica doña Isabel, al que siguen varias ilustraciones sobre su reinado. Madrid, I82r. (Memorias de la R. Acad. de la Historia, VI)

CorRESPONDANCE de Charles-Quint et d'Adrien VI, publ. par M. Gachard. Bruxelles, etc., I859.

Correspondenz des Kaisers Karl V, mitgetheilt von. K. Lanz. Leipzig, I 844-46. $3 \mathrm{~V}$.

Croce, Benedetto. Intorno al soggiorno di Garcilasso de la Vega in Italia. Napoli, I 894 .

\section{A N D MONOGRAPHS}




\begin{tabular}{|c|c|}
\hline 442 & GARCILASO DE LA VEGA \\
\hline & 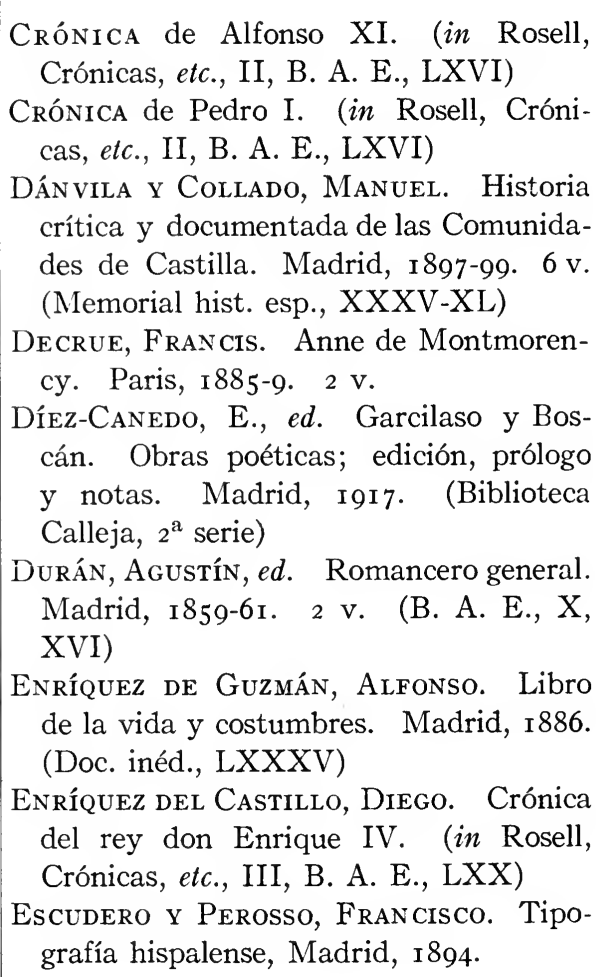 \\
\hline & H I PA N I NOTES \\
\hline
\end{tabular}




\section{LIF E A N D W O R K}

Fernández de Navarrete, Eustaquio.

Vida del célebre poeta Garcilaso de la Vega. Madrid, I850. (in Doc. inéd., XVI, I-292)

Fernández de Oviedo y Valdés, GoxzaLo. Libro de la Cámara Real del príncipe don Juan. Madrid, I87o. (Bibliófilos españoles)

- Relación de lo sucedido en la prisión del rey de Francia. (in Doc. inéd., XXXVIII, 404-530)

Ferrer del Río, ANtonio. Historia del levantamiento de las Comunidades de Castilla. Madrid, i 850 .

Flamini, Francesco. Il Cinquecento. Milano, [1902].

Fontanus, Iacobus. De bello Rhodio. (in Schardius redivivus, II, 88-I 2 I)

Foulché-Delbosc, Raymond, ed. Cancionero castellano del siglo XV. Madrid, I9I2-I5. 2 v. (Nueva B. A. E., XIX, XXII)

Fuente, Vicente de la. Historia de las universidades en España. Madrid, I88489. $4 \mathrm{r}$

\section{A N D MONOGRAPHS}




\begin{tabular}{|c|c|}
\hline 444 & GARCILASO DE LA VEGA \\
\hline & 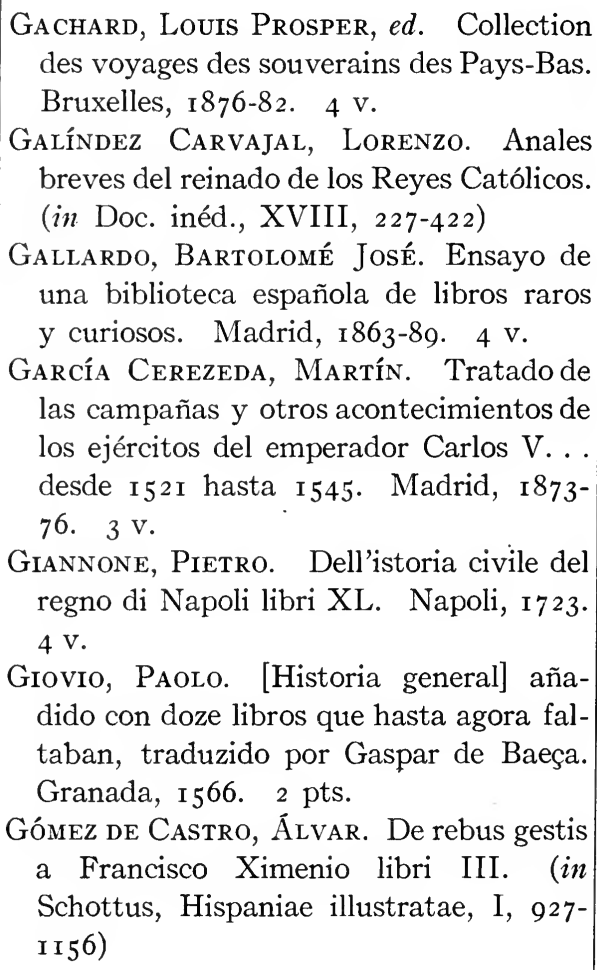 \\
\hline & H I P A N I C NOTES \\
\hline
\end{tabular}




\section{LIFE A N D WORKS}

Haebler, Konrad. Bibliografía ibérica del siglo XV. La Haya \& Leipzig; I903. Herrera, Fernando de, ed. Obras de Garcilasso de la Vega con anotaciones. Sevilla, I580.

Hume, Martin A. S. Spain: its greatness and decay. Cambridge, 1905.

Illescas, Gonzalo DE. Jornada de Carlos $\mathrm{V}$ a Túnez. (in Rosell, Historiadores, etc., I, B. A. E., XXI)

ItINÉRAIRe de Charles-Quint de I506 a 1531. (in Gachard, Collection des voyages, etc., II, I-50)

LE Journal d'un bourgeois de Paris (I515-1536), ed. V.-L. Bourrilly. Paris, I9IO.

Justi, Karl. Ein Bildnis des Dichters Garcilaso de la Vega. (in Jahrbuch der k. preuss. Kunstsammlungen, XIV (1893), I 77-90)

_ Garcilaso de la Vega. (in España moderna, t. 3 Io (oct. I9I4), I35-I 50)

Latour, Antolne DE. Tolède et les bords du Tage. Paris, I860.

LaURencín, Marqués DE. Documentos

\section{A N D MONOGRAPHS}




\begin{tabular}{|c|c|}
\hline 446 & GARCILASO DE LA VEGA \\
\hline & 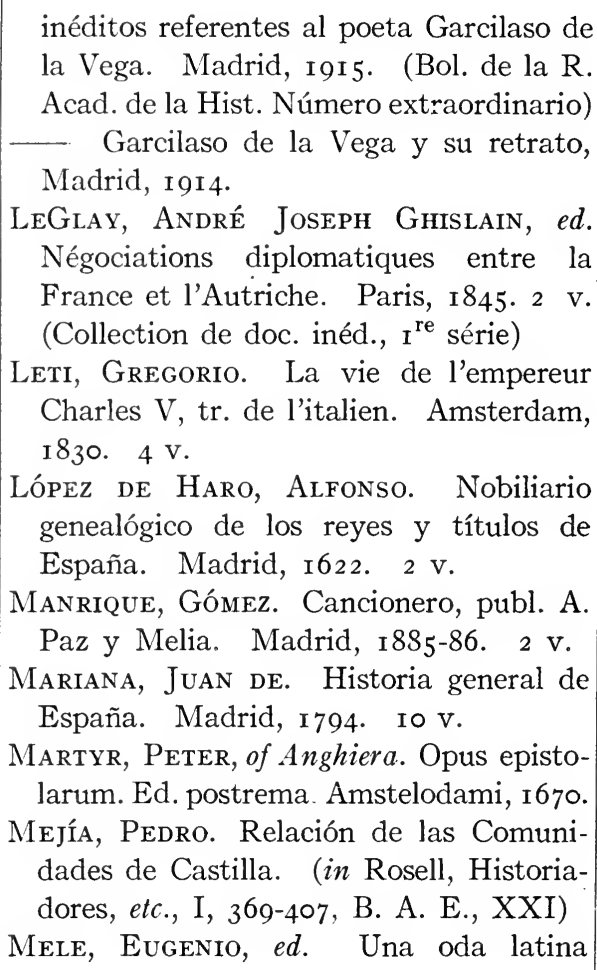 \\
\hline & H I P A N I C NOTES \\
\hline
\end{tabular}




\section{LIFE A N D W O R K}

inédita de Garcilaso de la Vega y tres poesías a él dedicadas por Cosimo Anisio. (in Revista de historia y literatura, etc., III (I898), 362-8)

Menéndez y Pelayo, Marcelino. Bibliografía hispano-latina clásica. Tomo I. Madrid, I902. (No more published.)

- Juán Boscán, estudio crítico. Madrid, 1908. (Antología de poetas líricos castellanos, XIII)

Mesonero Romanos, Ramón de, ed. Dramáticos posteriores a Lope de Vega. Madrid, I 858-59. 2 v. (B. A. E., XLVII, XLIX)

Mignet, François Auguste Marie. Rivalité de François $I^{\text {er }}$ et de CharlesQuint. Paris, 1875. 2 v.

Morales, Ambrosio de. Discurso de la verdadera descendencia del glorioso doctor Santo Domingo. (in Ocampo, Coronica general de España. Madrid, I 79I-92, X)

Moreau, Sébastien. La prinse et delivrance du Roy, venue de la Royne, seur aisnée de l'Empereur, etc. Paris, I 835.

\section{A N D MONOGRAPH S}




\begin{tabular}{|c|c|}
\hline 448 & GARCILASO DE LA VEGA \\
\hline & 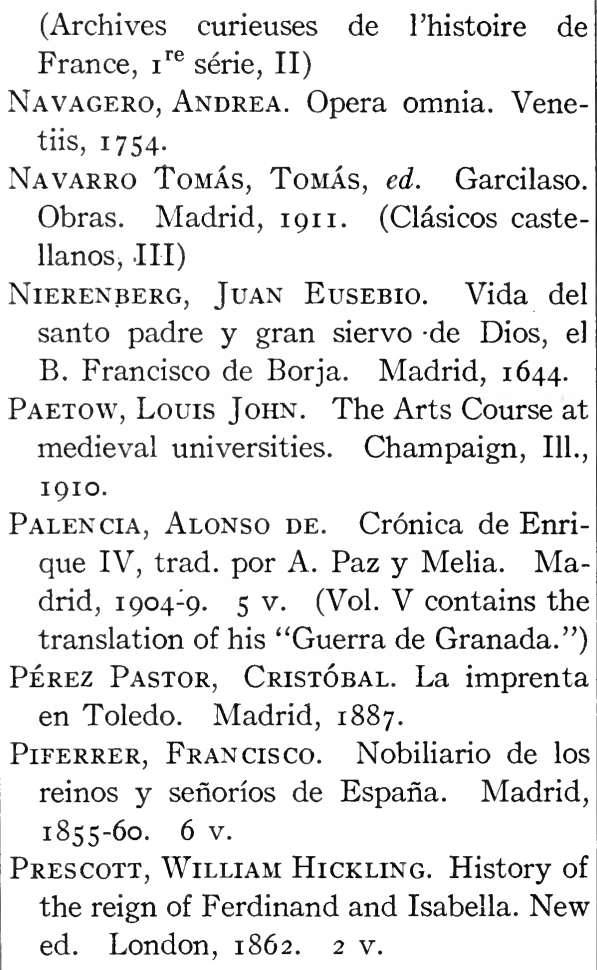 \\
\hline & H I P A N I N NTES \\
\hline
\end{tabular}




\section{LIFE A N D WORKS}

Pulgar, Hernando del. Claros varones de Castilla, Madrid, I775.

Crónica de Fernando e Isabel. (in Rosell, Crónicas, etc., III, BAA.E., LXX) Ranke, Leopold. L'Espagne sous CharlesQuint, Philippe II, \& Philippe III, tr. par J.-B. Haiber. $2^{\mathrm{e}}$ éd. Paris, 1873. Robertson, Williay. History of the reign of the emperor Charles the Fifth. Philadelphia, n. d.

Rodríguez Villa, Antonio. El emperador Carlos V y su Corte (I522-I539). Cartas de D. Martín de Salinas. (in Bol. de la R. Acad. de la Hist., XLII-XLVI, 1903-5)

Rosell, Cayetano, ed. Crónicas de los reyes de Castilla. Madrid, I875-78. $3 \mathrm{v}$. (B. A. E., LXVI, LXVIII, LXX)

- Historiadores de sucesos particulares. Madrid, I858-63. 2 v. (B. A. E., XXI, XXVIII)

Rosso, Gregorio. Historia delle cose di Napoli sotto l'imperio di Carlo Quinto, cominciando dall'anno $\mathrm{I}_{526} 6$ per insino all'anno I537. Napoli, I635.

\section{A N D M N O G A P H S}




\begin{tabular}{|c|c|}
\hline 450 & GARCILASO DE LA VEGA \\
\hline & 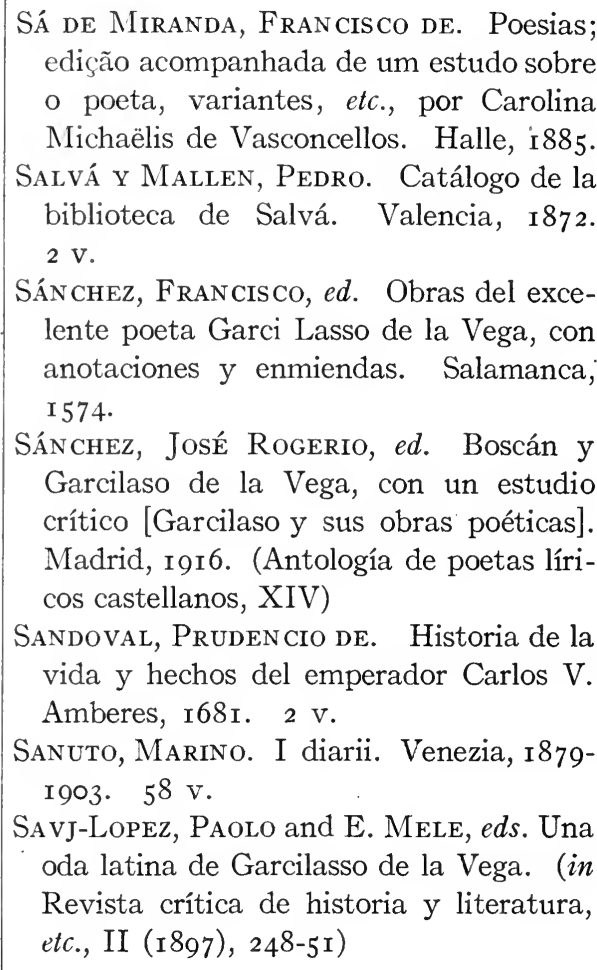 \\
\hline & H I P A N I NOTES \\
\hline
\end{tabular}




\section{I F E A N D W O R K}

SchaRdIUS redivivus, sive Rerum germanicarum scriptores varii. Giesse, I673. $4 \mathrm{~V}$. in $\mathrm{I}$.

Schottus, Andreas, ed. Hispanix bibliotheca, seu De academiis ac bibliothecis . . tomis III distincta. Francofurti, I608.

- Hispaniæ illustratæ, seu Rerum urbiumque Hispaniæ, etc., scriptores varii. Francofurti, I603-8. 4 v.

Sepúlveda, Juan Ginés. Opera. Matriti, I780. $4 \mathrm{~V}$.

Sosa, Gerónimo de. Noticia de la gran casa de los marqueses de Villafranca. Napoles, 1676 .

Tayayo de Vargas, Tomás, $e d$. [Obras de] Garcilasso de la Vega. Madrid, I622.

Ticknor, George. History of Spanish liter-

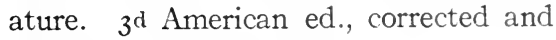
enlarged. Boston, $1863.3 \mathrm{v}$.

- Historia de la literatura española, trad. con adiciones y notas críticas por Pascual de Gayangos. Madrid, I $851-56$. $4 \mathrm{v}$.

Torre, Antonio de la. La universidad

\section{A N D MONOGRAPH}




\begin{tabular}{|c|c|}
\hline 452 & GARCILASO DE LA VEGA \\
\hline & 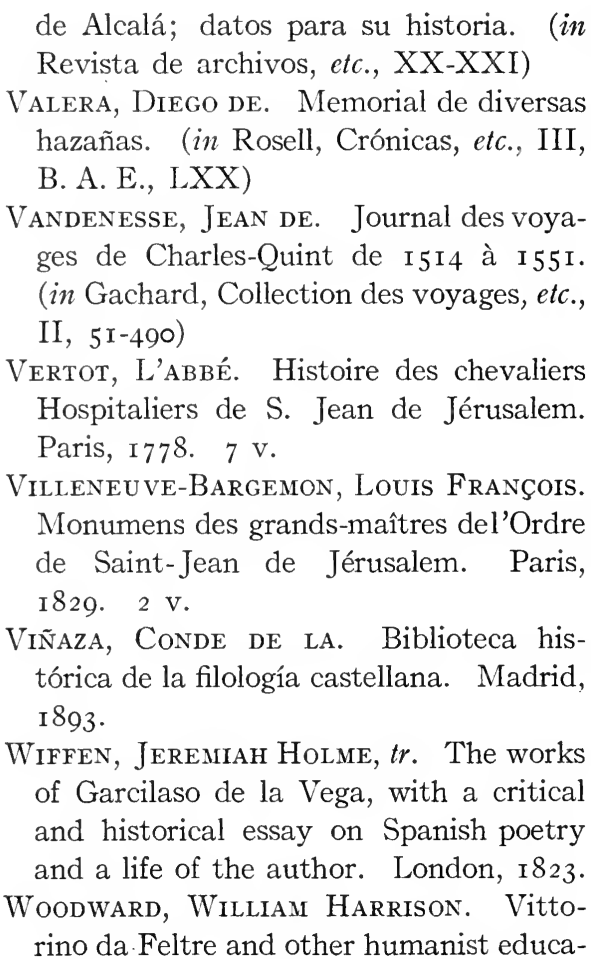 \\
\hline & H I P A N I C NOTES \\
\hline
\end{tabular}




\section{I F E A N D W O R S}

tors: essays and versions. Cambridge, I897.

Zapata, Luis. Carlo famoso. Valencia, I 566 .

- Miscelánea. (in Memorial hist. esp., XI)

Zinkeisen, Johann Milhelir. Geschichte des osmanischen Reiches in Europa. Hamburg, etc., r840-63. $7 \mathrm{~V}$.

ZÚÑIga, Fraxcesillo DE. Crónica. (in

Castro, Curiosidades, etc., pp. 0-54, B. A. E., XXXVI)

— Epistolario. (in id. pp. 55-62)

Zurita, Gerónimo. Anales de la corona de Aragón. Zaragoza, I669-7 . 7 v. 



\section{I F E A N D W O R K S}

\section{NOTES}

2,I Lettera seconda, and Viaggio in Ispagna (in Opera omnia, pp. 268, 3I5.)

3, r. Vida, I2.

3,2. Obras de Garcilasso, I6.

3,3. Id., I4-I5.

3,4. See pp. $64-67$.

4,r. Archivo histórico nacional. Ordenes militares. Santiago. Pruebas de nobleza. Garcilaso de la Vega y de Guzmán. I523. $\mathrm{N}^{\circ}$. 8613. Cf. Appendix A.

4,2. Id., Garcilaso de la Vega y Zúñiga. 1543. No. 8634 .

4,3. See Note $78,2$. .

5,r. If the phrase used by Garcilaso, "en mi perfeta edad" (Son. XXVIII, 9), is a reference to the generally accepted theory that the erowning point of life is reached at the age of thirty-five, then his birth cannot have been later than I50I. It is possible that he has in mind the expression of Dante. "E io credo che nelli perfettamente naturati esso [i] punto sommo dell'Areo della vita] ne sia nel trentacinquesimo anno" (Convivio, IV, 23.)

\section{A N D M O N O G R A H S}




\begin{tabular}{|c|c|}
\hline 456 & GARCILASO DE LA VEGA \\
\hline & $\begin{array}{l}\text { 5,2. The principal accounts of Garcilaso's } \\
\text { family are those of Gonzalo Fernández de } \\
\text { Oviedo and Argote de Molina. Oviedo's ac- } \\
\text { count is found in his Ms. Batallas y quin- } \\
\text { cuagenas (in the Academia de la Historia of } \\
\text { Madrid, I2-2I-5, No. 96, ff. } 417 \mathrm{r}^{\circ}-422 \mathrm{v}^{\circ} \text { ) } \\
\text { under the title, "El muy magnifico señor Gar- } \\
\text { cilaso de la Vega". The Ms., which is in- } \\
\text { titled "Libro que trata del blason de todas las } \\
\text { armas e diferencias dellas," is described by } \\
\text { Clemencín (Elogio, 22o-235). There is a } \\
\text { copy in the Boston Public Library (3o9o.8). } \\
\text { On the relations of this work to the Quin- } \\
\text { quagenas of the same author, see the introduc- } \\
\text { tion of Vicente de la Fuente to the edition of } \\
\text { the Quinquagenas, Madrid, I88o. Vol. I. } \\
\text { Argote de Molina in his Nobleza del Anda- } \\
\text { luzia, Sevilla, I } 588 \text {, f. } 335 \mathrm{r}^{\circ}-\mathrm{v}^{\circ} \text {, traces the } \\
\text { family down to the Marquis of Santillana. } \\
\text { He mentions four generations prior to the } \\
\text { first Garci-Lasso de la Vega: Diego Gómez } \\
\text { de la Vega, Ruy Díaz de la Vega, Gonzalo } \\
\text { Ruiz de la Vega (cf. Zurita, I, I69 v }{ }^{\circ} \text { ), and } \\
\text { Pero Lasso de la Vega, Almirante de Castilla. } \\
\text { On the doubtful nature of this last title, see } \\
\text { Angel de los Ríos y Ríos, Ensayo histórico } \\
\text { E. sobre los apellidos castellanos, Madrid, }\end{array}$ \\
\hline & H I S P N I C NOTES \\
\hline
\end{tabular}




\section{I F E A D W O R K S}

I87 I, p. I89. For the possible origin of the name Lasso, see Ríos y Ríos, op. cit. and Rodrigo Amador de los Ríos, Santander. Barcelona, I89I, p. 638. Navarrete (Vida, Io-I2, I37-I40, 275) and Piferrer (Nobiliario, II, 242-244) give a summary of the matter.

5,3. On this first Garcilaso, cf. Fernández de Oviedo, Batallas, ms. cit., $4 \mathrm{I} 8 \mathrm{v}^{\circ}-4 \mathrm{I} 9 \mathrm{r}^{\circ}$; Crónica de Alfonso XI (in B. A. E. LXVI), pp. I85-86, I88, 193-96, I 98-99, 210-I I ; Zurita, II, 68; Mariana, IV, 91, 99, I0I-2, I06-7.

6,r. On the second Garcilaso, cf. Fernández de Oviedo, ms. cit., f. 419; Crónica de Alfonso XI, pp. 25I-52, 326, 345, 352, 369, 378, 384; Crónica de Pedro I (in B. A. E. LXVI), 406, 409, 4I3-15; Zurita, II, I05 $\mathrm{r}^{\circ}$, $143 \mathrm{r}^{\circ}$; Poema de Alfonso Onceno (ed. F. Janer, Madrid, I863) copla I662; Mariana, IV, I57, 202.

7,r. The Marquis of Santillana mentions his grandmother, Doña Mencía Cisneros, in his Prohemio (Obras, ed. Amador de los Ríos, Madrid, I852, p. 12.) On her daughter, Doña Leonor de la Vega, see Amador de los Ríos in his introduction to this edition, pp. $\mathrm{x}$-lviii.

\section{A N D M O N O G R P H S}




\begin{tabular}{|c|c|}
\hline 458 & GARCILASO DE LA VEGA \\
\hline & 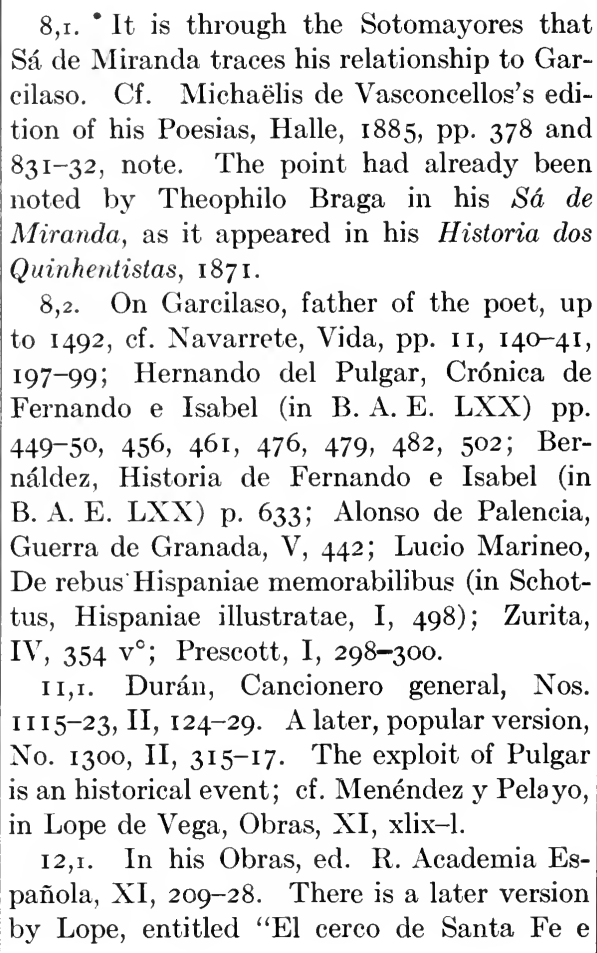 \\
\hline & H I S P A I C NOTES \\
\hline
\end{tabular}




\section{I F E A N D W O R K S}

ilustre hazaña de Garcilaso de la Vega" (Obras, XI, 23I-58). On the dates, of. the introduction of this volume, pp. xli, xlviii. Another and later version, by another author, called "El triunfo de Ave-María" (in Mesonero Romanos, Dramáticos posteriores a Lope de Vega, II, I73-94) is still performed at Granada on the anniversary of the conquest of the city, January 2. Cf. the introduction to this volume of the Dramáticos posteriores, p. xiii, and Lope de Vega, Obras, XI, lvii. I2,2. See p. 8 .

12,3. I, 224, 283-84. Cf. also Enríquez del Castillo, Crónica del rey don Enrique IV (in B. A. E., LXX), p. го7; Diego de Valera, Memorial de diversas hazañas (in B. A. E., LXX), p. 5 .

I2,4. Cancionero, I, I03-II5. On the dates and the family, of. the notes, II, $3+7-48$. Diego de Burgos mentions this Garcilaso in his Triunfo del marqués de Santillana (in $R$. Foulché-Delbosc, Cancionero castellano del siglo XV, II, 544) and Hernando del Pulgar treats of him in his Claros varones, Titulo $\mathrm{X} Y$. The Garcilaso who received a grant from Enrique IV in $147 \mathrm{I}$ (cf. Navarrete, Vida, pp. I97-98) is probably the son of this Garcilaso.

\section{A N D M O N G R A P H S}




\begin{tabular}{|c|c|}
\hline 460 & GARCILASO DE LA VEGA \\
\hline & 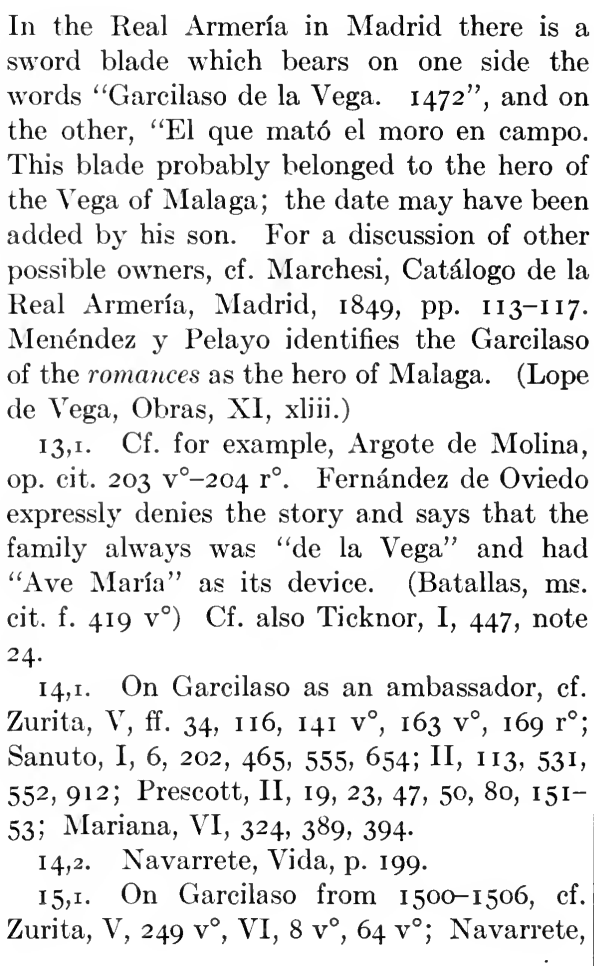 \\
\hline & HISTANIC NUA ES \\
\hline
\end{tabular}




\section{I F E A N D W O R K S}

Vida, pp. I99-200; Galíndez Caravajal, Anales breves (in Doc. inéd., XVIII,) p. 307; Mariana, VII, 80, 87. There is another version of the meeting of Fernando and Garcilaso, in which Garcilaso plays the role usually assigned to the Count of Benavente. Cf. Álvar Gómez de Castro, De rebus gestis Francisci Ximenii libri III (in Schottus, Hispaniae illustratae, I, 990); Prescott, II, 279. Bernáldez (op. cit. p. 726) does not mention Garcilaso.

I6, I. On Garcilaso from I506 to I512, cf. Navarrete, Vida, 200; Bernáldez, p. 727; Prescott, II, 306; Mariana, VII, Io7.

16,2. On the family of Dona Sancha, cf. Navarrete, Vida, pp. I $42-47,277,279$. For the origin of the Guzmanes, see Ambrosio de Morales, Discurso de la verdadera descendencia del glorioso doctor Santo Domingo (in Ocampo, Corónica general de España, Vol. X.) I6,3. P. I4I.

I 8, I. Id., pp. I40-4I.

I8,2. Son. XVI.

19,r. Obras de Garcilasso, p. I4.

19,2. Vida, p. 13. His brother, Pedro Laso, as heir to the estate was brought up at the Court and was a pupil of Peter Martyr.

\section{A N D M O N O R A P H S}




\begin{tabular}{|c|c|}
\hline 462 & GARCILASO DE LA VEGA \\
\hline & 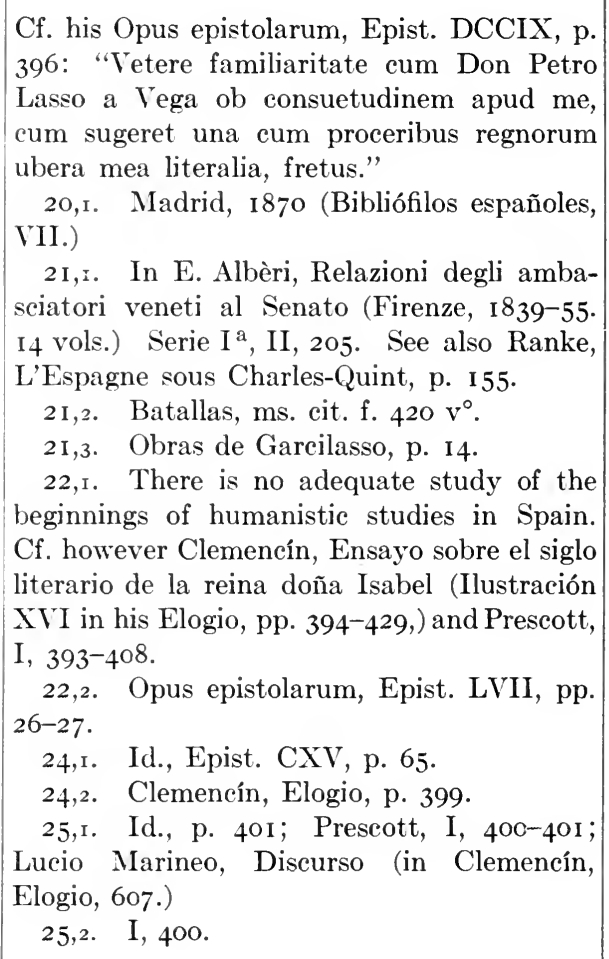 \\
\hline & H I S A N I C N O TES \\
\hline
\end{tabular}




\section{I F E A N D W O R K S}

25,3. Vicente de la Fuente, Historia de las universidades en España (Madrid, I88489. 4 vols.) II, I $44-105$.

26, . . Peter Martyr, Opus epistolarum, Epist. CCCLXXY, p. 200. For his dates, ef. Antonio, Bibliotheca nova, I, 326-27; Fuente, II, I06; Gómez de Castro (in sichottus, Hispaniae illustratae, I, I I 4I.)

26,2. In his Discurso (in Clemencín, Elogio, p. 609.) The misprint "Cirillo" is corrected to "Citillo" on p. 6I I.

26,3. Gallardo, Ensayo, III, 73; IV, ıо о, IOI 2 .

27, r. Bibliotheca nova, I, 58 .

27,2. Antonio, op. cit., I, 765; Gómez de Castro, loc. cit.

27,3. On the subjects studied in the Middle Ages, ef. P. Abelson, The Seven Liberal Arts, New York, 1906, and L. J. Paetow, The Arts course at medieval universities, Champaign (Ill.), r9io.

28, I. Abelson, p. 35, note $\mathbf{I}$.

30,r. On humanistic education. cf. W. H. Woodward, Vittorino da Feltre and other humanist educators, Cambridge, I 897.

31,r. Clemencín, pp. 456, 467. Editions of the Doctrinale were printed at Barcelona

\section{A N D M O N O G R P H S}




\begin{tabular}{|c|c|}
\hline 464 & GARCILASO DE LA VEGA \\
\hline & 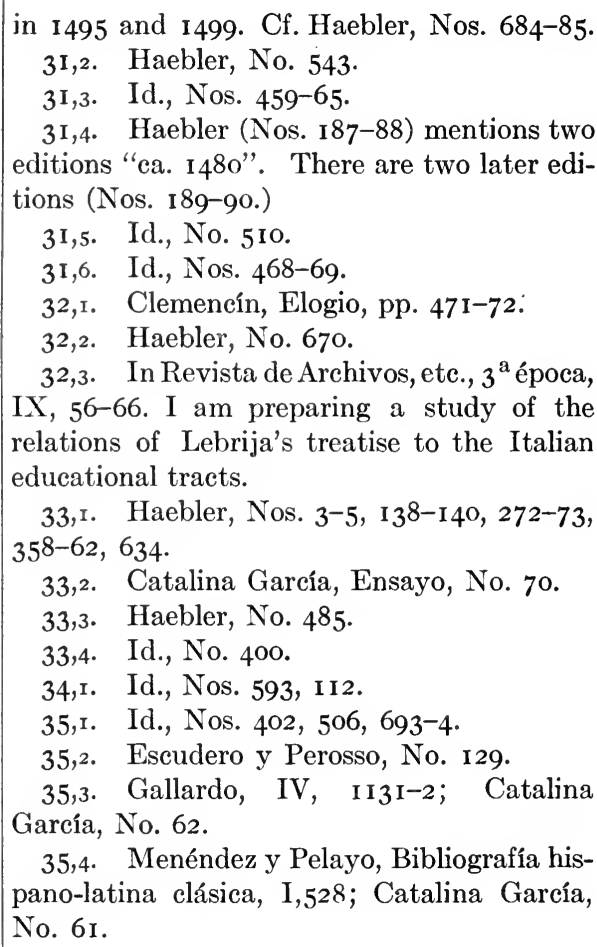 \\
\hline & H I S P A I C NOTES \\
\hline
\end{tabular}




\section{I F E A D W ORK S}

35,5. Salva, I, 527 (under No. I449.)

35,6. Clemencín, Elogio, pp. 470-I.

36,1. Cited by the Conde de la Viñaza in his Biblioteca histórica de la filología castellana, Madrid, I893, col. 22.

36,2. Opus epistolarum, Epist. CCXLVI. p. 139 .

37,r. Laurencín, Documentos, p. 133.

38, . Catalina García, Nos. r7-18.

38,2. Haebler, No. 470 .

38,3. Fontanini-Zeno, I, 5.

38,4. Brunet, III, col. 1578 .

$39, \mathrm{r}$. Lebrija in his preface says that the time is opportune for his work "por estar la nuestra lengua tãto en la cumbre que mas se puede temer el decendimiento della que esperar la subida." (Reproduction of the editio princeps by E. Walberg, Halle a. S., I909, f. a iiii $r^{\circ}$.)

39,2 . There is corroboration of the use of the Disticha Catonis and of Sallust as elementary texts in two references from Francesillo de Zúniga (cited by Menéndez y Pelayo, Juan Boscán, pp. 47-8), one in which he speaks of Fray Severo as "mostrador de Catón y Terencio á los nietos del Duque de Alba" (Crónica, p. 28) and the other in his anecdote

\section{A N D M O N O G R P H S}




\begin{tabular}{|c|c|}
\hline 466 & GARCILASO DE LA VEGA \\
\hline & 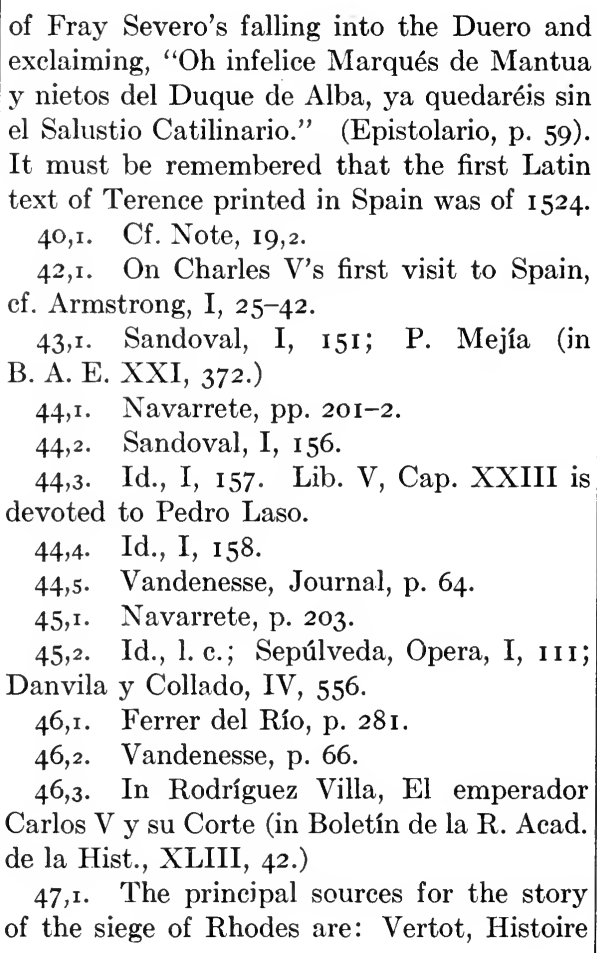 \\
\hline & H I S P A I C NOT E S \\
\hline
\end{tabular}




\section{I F E A N D W O R K S}

\section{7}

des Chevaliers Hospitaliers de S. Jean de Jérusalem, III, 237-3I7 (he used the works of Jacques de Bourbon and Giacomo Bosio); Fontanus, De bello Rhodjo; Charrière, Négociations de la France dans le Levant, Vol. I, passim; the volumes of Sanuto's Diarii covering 1522 and I523 (XXXIIIXXXIV); Zinkeisen, Geschichte des osmanischen Reiches in Europa, II, 62 I-32.

47,2. Sanuto, XXXIII, 398-9; Charrière, I. $9 \mathrm{I}-2$.

48, r. Correspondance de Charles-Quint et d'Adrien VI, publ. par M. Gachard, pp. Ioo-I. 48,2. Correspondenz des Kaisers Karl V. I, 66-8.

48,3. Rodríguez Villa, in Boletín, etc., XLIII, 47.

49, I. For a discussion of this conflict, cf. Galíndez Carvajal, Anales breves (in Doc. inéd. XVIII, 39I-6.)

49,2. Zapata, Carlo famoso, f. $67 v^{\circ}$ (cited by Menéndez y Pelaỹo, Juan Boscán, p. 39); Rodríguez Villa, Boletín, etc., XLIII, 55.

49,3. On Pedro de Toledo, cf. Sosa, Noticia de la gran casa de los Marqueses de Villafranca, Napoles, I676; Giannone, IV, $45^{-7}$.

\section{A N D MONOGRAPH S}




\begin{tabular}{|c|c|}
\hline 468 & GARCILASO DE LA VEGA \\
\hline & $\begin{array}{l}\text { 50,r. On Boscán, cf. Menéndez y Pelayo, } \\
\text { Juan Boscán, esp. pp. 54-5. } \\
\text { 50,2. Rodríguez Villa, Boletín, etc., } \\
\text { XLIII, 55. } \\
\text { 50,3. Vertot, III, 332. Zapata (l. c.) } \\
\text { states that they sailed from Barcelona, but } \\
\text { Alonso Enríquez (Libro de la vida y costum- } \\
\text { bres, p. 3I) also gives Cartagena as the port } \\
\text { of departure. } \\
\text { 52,r. Vertot, III, 332-3; Fontanus (in } \\
\text { Schardius redivivus, II, I20); Sanuto, XXX- } \\
\text { III, 535, 548, 58I, 603; Correspondance de } \\
\text { Charles-Quint et d'Adrien VI, p. I34. } \\
\text { 52,2. Sanuto, XXXIV, 89-90. } \\
\text { 53,I. Id., XXXII, 600-I, 6I5; XXXIV, } \\
\text { 282; Vertot, III, 327-9. } \\
\text { 54,I. Vertot, III, 330-8. } \\
\text { 55, I. Rodríguez Villa, in Boletín, etc. } \\
\text { XLIII, I39. } \\
\text { 55,2. Cf. p. 58. } \\
\text { 56,r. Peter Martyr, Opus epistolarum, } \\
\text { Epist. DCCLXXI, p. 448; Rodríguez Villa } \\
\text { in Boletín, etc., XLIII, 66; Danvila y Col- } \\
\text { lado, V, 238-5I. } \\
\text { 57,r. Rodríguez Villa, in Boletín, etc., } \\
\text { XLIII, II3, I32; Peter Martyr, Epist. DCC- } \\
\text { LXXXI, pp. 456-8. }\end{array}$ \\
\hline & H I S A N I C N OTE S \\
\hline
\end{tabular}




\section{I F E A N D W O R K S}

57,2. Rodríguez Villa, XLIII, ı 4 ; Sandoval, I, 426.

57,3. Rodríguez Villa, XLIII, I37.

58, r. Obras de Garcilaso, p. I4.

58,2. Rodríguez Villa, in Boletín, XLIII, I $26-7$.

58,3 . Itinéraire, p. 34. The Journal of Vandenesse (p. 68) erroneously says "Arcos". 58,4 . Cf. ms. cited in Note $4, \mathrm{r}$.

58,5. Laurencín, Documentos, pp. 43-4.

59,1. Itinéraire, p. 34; Navarrete, p. 205; Rodríguez Villa, in Boletín, XLIII, I32.

6o, r. Peter Martyr, Epists. DCCLXXXIV and DCCLXXXIX, pp. 460, 463-4; Rodríguez Villa, in Boletín, etc., XLIII, I3 I, I36.

6o,2. Laurencín, Documentos, 44-5.

6I,I. Sepúlveda, Opera, I, I44-5; Peter Martyr, Epist. DCC XCI, pp. $465^{-6}$; Rodríguez Villa, in Boletín, etc., XLIII, I39, I43, I 45 .

6I,2. Laurencín, Documentos, p. 82.

61,3. Sepúlveda (Opera, I, I47) says "tertio Kalendas Martias", which would be February 28 th (1524 was a leap-year). Salinas gives the date as the 27 th (Rodríguez Villa, in Boletín, etc., XLIII, 147) as does Peter Martyr (Opus epistolarum, p. 468.)

\section{A N D M O N O G R P H S}




\begin{tabular}{|c|c|}
\hline 470 & GARCILASO DE LA VEGA \\
\hline & 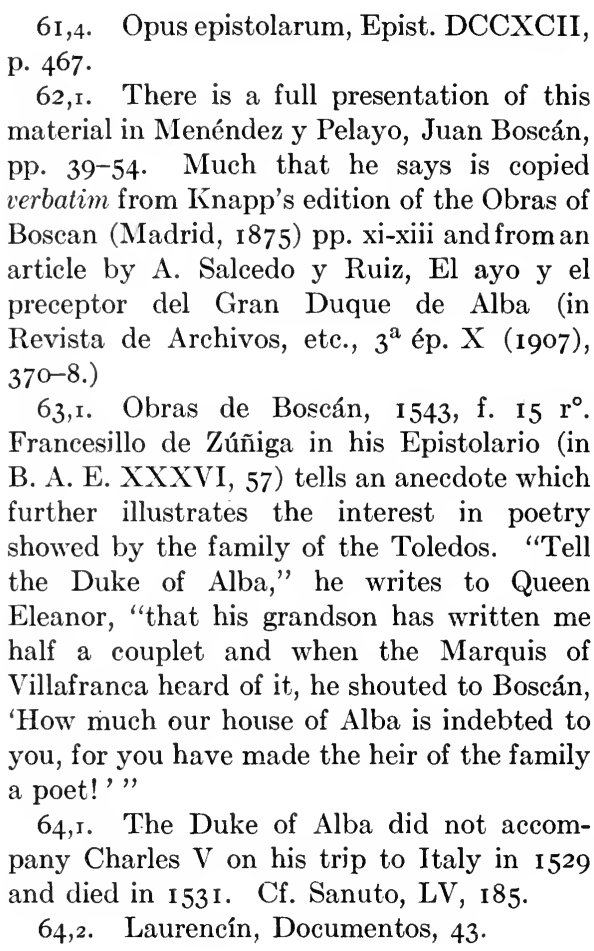 \\
\hline & H I S P N I C NOTES \\
\hline
\end{tabular}




\section{I F E A N D W O R K S}

65, r. Schottus, Hispaniae bibliotheca, p. 579 .

65,2. On the family of Doña Elena, see Navarrete, Vida, pp. 150-I, 28 I.

65,3. Navarrete, Vida, 20 $4-5$.

66,r. Laurencín, Documentos, 49-66.

69,r. Oviedo, Relación (in Doc. inéd. XXXVIII, 406.)

70,r. Id., p. 424; Rodríguez Villa, in Boletín, etc. XLIII, 429, 47 I, 475.

70,2. Oviedo, Relación (in Doc. inéd., XXXVIII, 432-4.)

7I,r. Id., pp. 434-44; Sandoval, I, 543; Champollion-Figeac, p. 5I3.

72,r. Navagero, Opera, pp. 317-20. Navagero left Toledo on the $24^{\text {th }}$ and arrived at Seville on the 8th. Queen Germana left on the $25^{\text {th }}$ (Oviedo, l. c., p. 444 ) and was in Seville with Isabella of Portugal when Charles $\mathrm{V}$ arrived (Champollion-Figeac, p. 514). On the trip of Charles $V$, see Itinéraire, pp. 38-9. On the two ambassadors, see Menéndez $y$ Pelayo, Juan Boscán, pp. 60-93.

72,2. Sandoval, I, $546 \mathrm{ff}$. For an account of the reception, see Navagero, Opera, p. 326.

73,r. Oviedo, Relación (in Doc. inéd. XXXVIII, 453-8, 462.)

\section{A N D M O N O G R P H S}




\begin{tabular}{|c|c|}
\hline 472 & GARCILASO DE LA VEGA \\
\hline & 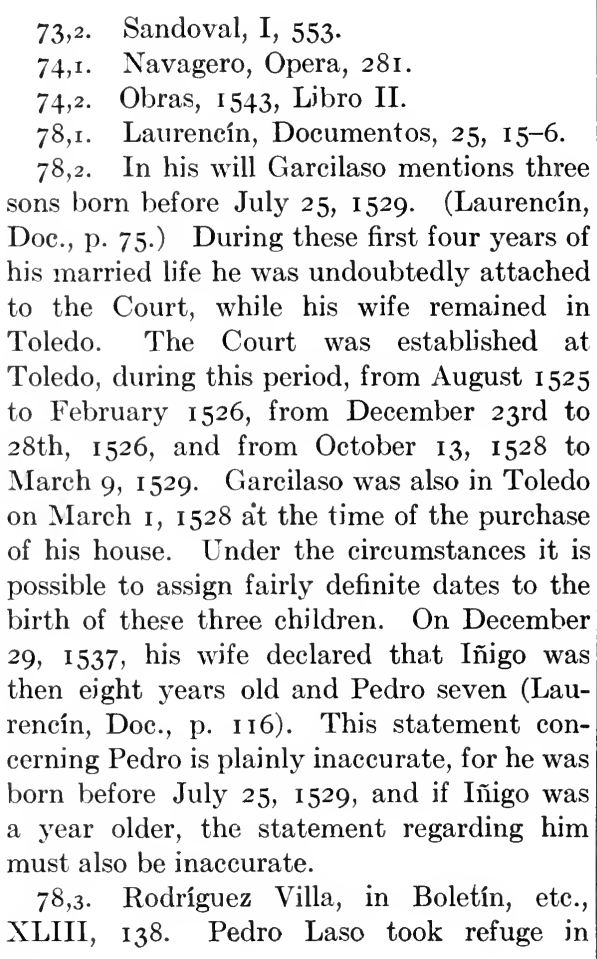 \\
\hline & H I S P A I C NOTES \\
\hline
\end{tabular}




\section{I F E A N D W O R K S}

Portugal and his activities there were closely watched by the representatives of the Emperor (Danvila y Collado. V, 496, 50 I). He was finally pardoned, though still exiled from all Spain except the county of Feria. On May I3, I526 this exile was reduced, although he was still forbidden to enter within five leagues of the Court or of Toledo. (Id., $\mathrm{V}, 507-8$.) Even this decree must have been annulled or forgotten, for he was in Toledo on April $I 7$, 153I. His mother had already bought back for him his estate of Los Arcos which had been confiscated in 1524 (Laurencín, Doc., p. I6.) 79, r. In B. A. E., XXXVI, 53.

79,2. Camoens, Rimas varias commentadas por Manuel de Faria y Sousa. Lisboa, 1685-8. 5 pts. V, 2II-2. (Cited by C. Michaëlis de Vasconcellos in her edition of the Poesias of Sá de Miranda, p. 833.)

79,3. Id.. p. 820; Braga, Sá de Miranda, I 896, p. 50.

8o, r. Miscelánea, p. 384 .

80,2 . Itinéraire, pp. $3^{8-46 .}$

8o,3. Ff. $82 \mathrm{v}^{\circ}-83 \mathrm{r}^{\circ}$.

80,4. No. I7969 (Gayangos, No. 693).

8I,r. Archivo histórico Nacional. Leg. $\mathrm{N}^{\circ}$. 230, $\mathrm{N}^{\circ}$ 3II7. I am indebted to the late

\section{A N D M O N O G A P H S}




\begin{tabular}{|c|c|}
\hline 474 & GARCILASO DE LA VEGA \\
\hline & 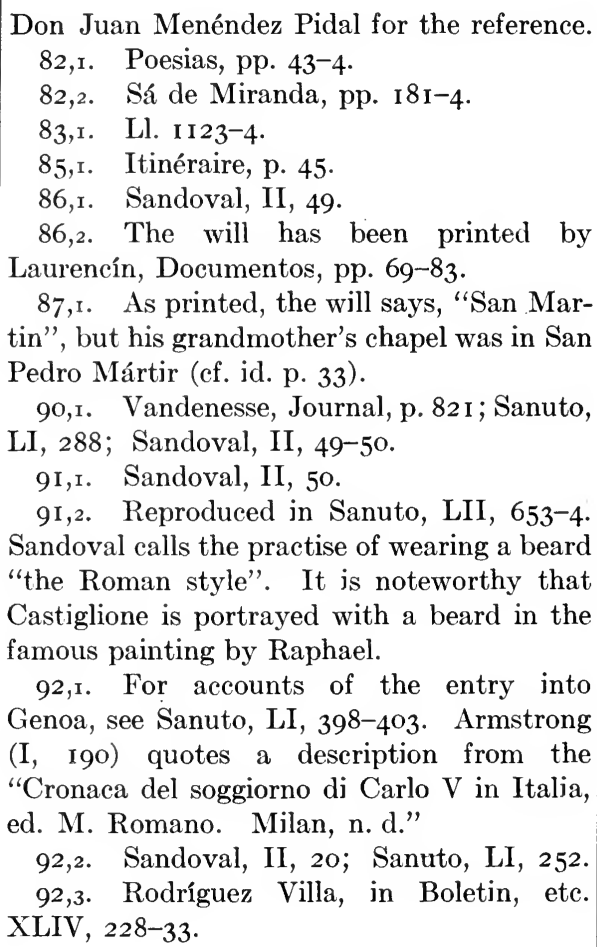 \\
\hline & H I S P A I C NOTES \\
\hline
\end{tabular}




\section{I F E A N D W O R K S}

92,4. Vandenesse, Journal, 85; Sanuto, LII, I 42-5, I 80-4.

93,r. Sanuto, LII, 350-5.

94,r. Sandoval, II, 57; Sanuto, LII, 60319.

94,2. Sandoval, II, 58-6I; Sanuto, LII, $628-52$.

95,r. Sanuto, LII, 615.

95,2. Leti, La vie de l'empereur Charles V, I, 376 .

95,3. Navarrete, Vida, pp. 205-7.

96, I. Id., 26-7.

97, r. Sandoval, II, 28.

98 , r. Moreau, pp. 4I 5-5I; Le journal d'un bourgeois de Paris, 342-4; Decrue, I, I60-2; Sandoval, II, 98-9; Sanuto, LIII, 34t-5.

99,r. Navarrete, Vida, p. 208. The opinion of Anne de Montmorency concerning the new queen is representative: "J'ay trouvé principallement la royne . . autant saige, belle et honneste dame, et qui m'a tenu de si bons et honnestes propos qu'il ne seroit possible de plus." (Letter to Marguerite d'Autriche, July I, I530, in Le Glay, Négociations, II, 742.)

99,2. Calendar of State Papers. Spanish to 1543 (Henry VIII), IV, I, 668.

\section{A N D M O N O G R P H S}




\begin{tabular}{|c|c|}
\hline 476 & GARCILASO DE LA VEGA \\
\hline & 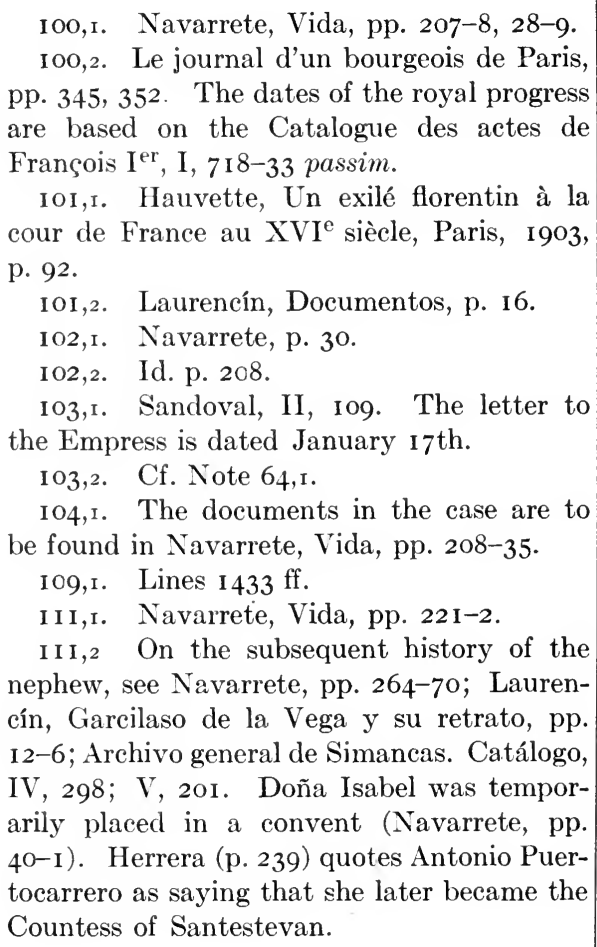 \\
\hline & H I S P N I C N OTES \\
\hline
\end{tabular}




\section{I F E A D W O R K S}

I I I,3. Vida, p. + I.

I I3,r. For example, Nos. III and IV.

I 4 , r. Navarrete, p. 222.

II4,2. Sanuto, LVI, 567, 7 I8, 726, 860 , 902, 930 .

I 4 4. Navarrete, Vida, 48-9, 23.5.

I 4,4. Obras de Garcilasso, p. I.5.

I I 5, I. For example, Cienfuegos. II, II, 50: Wiffen, p. I3I-2.

I 15,2. Lines I $505 \mathrm{ff}$.

I I 5.3. Sanuto, LVII, I I5.

i 6, r. Croce, Intorno al soggiorno, p. 8 , note $I$.

I I8, r. Flamini, Il Cinquecento, pp. Io , ı09; Minieri-Riccio. Cenno storico delle Accademie fiorite in Napoli (in Archivio storico per le prov. napoletane, V (I880), 362-3.)

I 8,2 . Id., I, 363-4.

I 8,3 . Donati in libros duodecim Aeneidos quae antea desiderabatur absoluta interpretatio. Neapnli. I 535. f. $2 \mathrm{v}^{\circ}$. Liagno in his Kritische Bemerkungen über kastilische Literatur, I830. (II, I08) speaks of the commentary. as being that of Servius. (Cited by Ticknor, I, 45I, note.) See Appendix B.

I 9, r. No. XXIV.

I 9,2. Cited by Fiorentino in his edition

\section{A N D M O NOGRAPH S}




\begin{tabular}{|c|c|}
\hline 478 & GARCILASO DE LA VEGA \\
\hline & 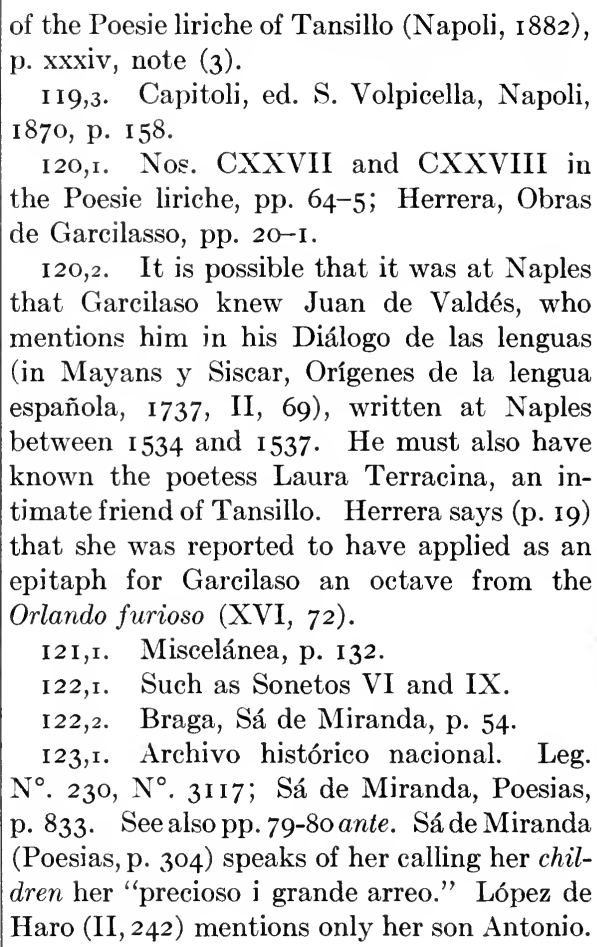 \\
\hline & H I S P A I C NOTES \\
\hline
\end{tabular}




\section{I F E A N D W O R K S}

124,r. Capasso, Vicaria vecchia (in Arch. stor. nap., XV, 422-3 note) cited by Croce, pp. 7-8; Navarrete, Vida, p. 236; Vandenesse, Journal, p. Io6.

124,2. Los quatro libros del Cortesano, compuestos en italiano y agora nuevamente traduzidos en lengua castellana. Barcelona, I 534, f. II $\mathrm{r}^{\circ}$.

I 24,3 . Ff. III-IV.

I 25, r. Laurencín, Documentos, p. 25.

125,2. Capasso, l. c. (cited by Croce, l: c.)

126, r. Gregorio Rosso, Historia delle cose di Napoli, p. 97.

127, I. See Note 5, r.

129, r. Navarrete, Vida, pp. 236-7.

129,2. Vandenesse, Journal, p. I09; Salinas wrote from Palencia on September $4^{\text {th }}$ that they were expecting him (in Bol. etc., XLV, 34).

I30,r. Francisco Sánchez in his note on the passage, says, "Por Valclusa, donde nacio Madona Laura, dama del Petrarca," and his statement has been repeated by all of the commentators and biographers. It is plainly inaccurate; Avignon and not Vaucluse was the birthplace of Laura and it was at Avignon that her ashes rested. Moratín the Younger

\section{A N D M O N O R A P H S}




\begin{tabular}{|c|c|}
\hline 480 & GARCILASO DE LA VEGA \\
\hline & $\begin{array}{l}\text { was better informed on the subject, for writ- } \\
\text { ing to Jovellanos from Avignon on April I3, } \\
\text { I } 787 \text {, he begins, "Escribo á usted desde la } \\
\text { tierra } \\
\text { 'Do nació el claro fuego de Petrarca } \\
\text { Y donde están del fuego las cenizas.', } \\
\text { In the same letter he remarks that the resting- } \\
\text { place of Laura's ashes was not discovered } \\
\text { until I } 533 \text { and that in that year Francis I } \\
\text { visited her grave in the Franciscan monastery } \\
\text { and wrote an inscription for her tomb. All } \\
\text { of which gives particular point to the closing } \\
\text { lines of Garcilaso's Epistola, written in I } 534 . \\
\text { (Cf. Obras póstumas, I } 867 \text {, II, 88-9o.) } \\
\text { I30,2. Navarrete, Vida, pp. 237-8. } \\
\text { I32,r. Id. pp. } 238-9 \text {. } \\
\text { I32,2. Rosso, p. I05. } \\
\text { I32,3. Id. p. Io7. } \\
\text { I33,r. Vandenesse, Journal, p. I I I. On } \\
\text { the campaign, see Sandoval, Sepúlveda, I- } \\
\text { llescas, and Cerezeda. } \\
\text { I33,2. Sandoval, II, I73-4; Sepúlveda, } \\
\text { I, 376. } \\
\text { I34,I. Giovio, f. I03; Illescas, (in B.A.E. } \\
\text { XXI, 456.) Fiorentino (in Tansillo, Poesie } \\
\text { liriche, p. 277) quotes a manuscript genealogy }\end{array}$ \\
\hline & H I S P A I C NOTES \\
\hline
\end{tabular}




\section{IF E A D W O R K S}

\section{1}

of the house of Carrafa by Angelo di Costanzo (Biblioteca Nazionale di Napoli, XIV, F, 39) which tells the same story.

134,2. Noticias de varios sucesos acaecidos desde el año I 52 I hasta el 1549, copiadas de un códice escrito de mano de Florian de Ocampo (Ms. in the Biblioteca Nacional, Madrid, $\mathrm{N}^{\circ}$. 9936) f. 3 I $\mathrm{r}^{\circ}$.

I35,r. Vida, p. 7 I.

I35,2. Vandenesse, Journal, p. I I3; Cerezeda, III, 303 .

136,r. In Doc. inéditos, XIV, 427.

I37, r. Vandenesse, Journal, pp. I I3-5; Castaldo, p. 48.

I37,2. Castaldo, pp. 48-9; Rosso, pp. I I 2-8; Sandoval, II, 2 I 8.

138, r. Castaldo, p. 55 .

138,2. Epistolarum familiarum libri VI, I 552, pp. 333-6.

I38,3. Delle lettere volgari, I552, I, $33^{2}$.

139,I. Herrera (p. 15) refers to the esteem in which he was held by the Marquis of Vasto, and in his comment on Soneto XXI remarks that some have thought that the poem was addressed to the Marquis of Vasto rather than to the Marquis of Villafranca, Don Pedro de Toledo.

\section{A N D MON O G R P H S}




\begin{tabular}{|c|c|}
\hline 482 & GARCILASO DE LA VEGA \\
\hline & 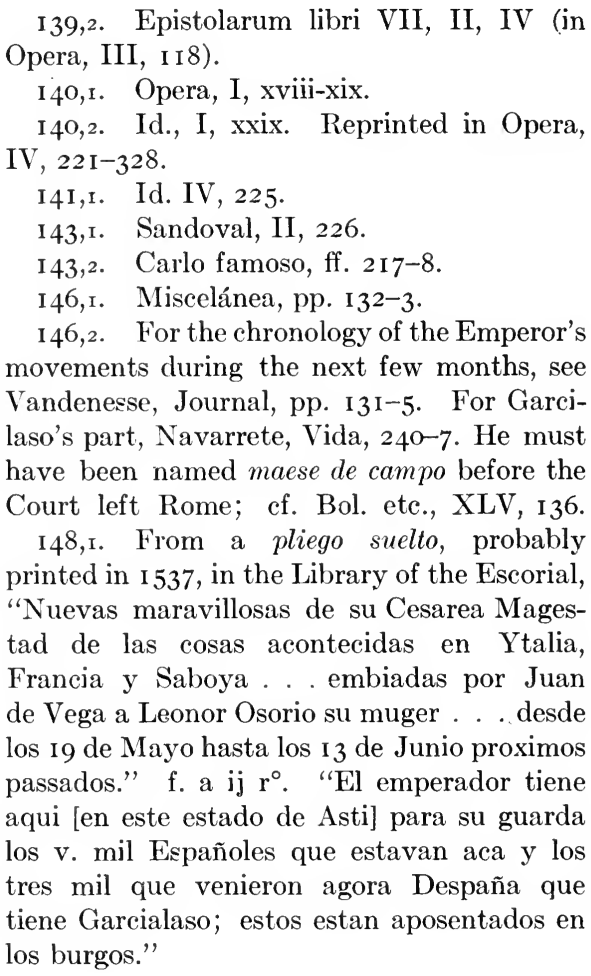 \\
\hline & H I S P A I C N OTES \\
\hline
\end{tabular}




\section{IFE A N D W O R K S}

I5o,r. Croce, pp. I3-4; Gutierre ed Cetina, in his Epístola to Hurtado de Mendoza (Obras, I 895, Epist. XIV, lines 40-2, II, I07) refers to the story of Garcilaso as

". . . de piedad $\searrow$ envidia llena,

digo de invidiosos de su gloria,"

but this is probably merely a reference to his untimely death.

I 50,2. Lines 37-40.

I 50,3. Cf. pp. 255-56.

I5I,I. Poesias, p. 295.

I52,r. Navarrete, Vida, pp. $25^{\mathrm{I}-2}$.

I 53, r. Tratado, II, I95-7.

I 56, I. Carlo famoso, f. 22 I.

I56,2. Martin Du Bellay, Mémoires, contenans quelques fragmens des Ogdoades de Messire Guillaume Du Bellay, La Rochelle, I 573 , p. 740 .

I57,I. Obras de Garcilasso, p. I6.

I57,2. There are numerous references to Garcilaso's death in the works of the Spanish historians, e.g., Giovio, f. I I5; Mariana, VII, 325; Sandoval, II, 233.

I58,r. The date is a matter of debate. Of the documents printed by Navarrete (pp. 258-9) one states that he died on the $13^{\text {th, }}$ another, the $14^{\text {th. A }}$ A third, says that his heirs

\section{A N D M O NOGRAPH S}




\begin{tabular}{|c|c|}
\hline 484 & GARCILASO DE LA VEGA \\
\hline & 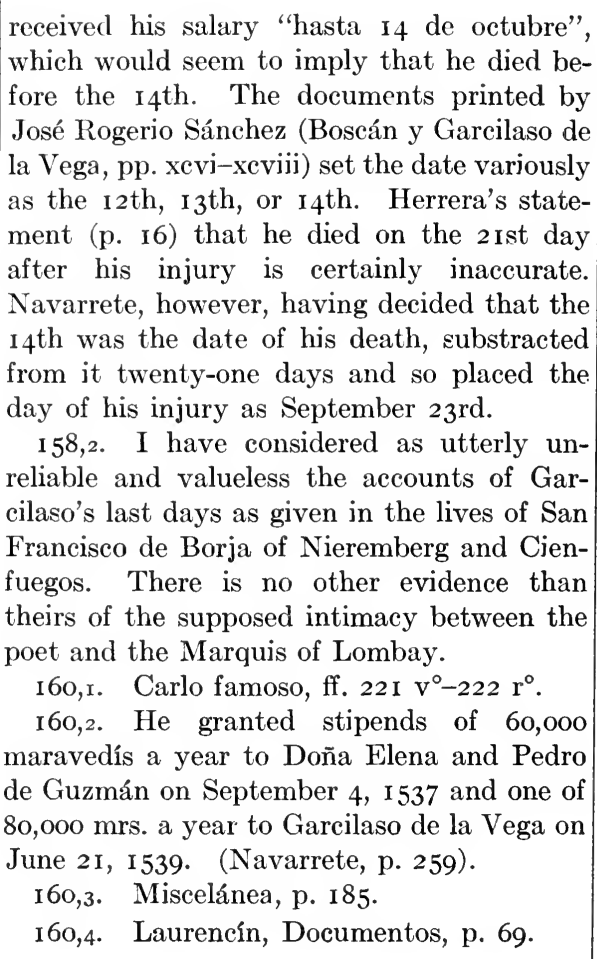 \\
\hline & H I S P A I C N.OTES \\
\hline
\end{tabular}




\section{I F E A N W O R K S}

I60,5. Id., p. I5I. The "Inventario, tasación y partición" of her estate are given in Laurencín (Documentos, pp. I I 5-53).

I6o,6. José Rogerio Sánchez, Juan Boscán, p. xevi.

I6I,r. On December 29, I537; cf. Laurencín, Documentos, p. I I6.

I6I,2. Navarrete, Vida, pp. 260-2. Doña Elena in her first will, dated August I 8, I 549 names Garcilaso as her heir (Laurencín, Documentos, p. I08.)

16I,3. Ms. in the Archivo histórico Nacional, cited in Note 4,2 .

\section{I62, 1. Cf. pp. 27 I-73.}

I62,2. Published by R. Menéndez Pidal in Boletín de la R. Academia Española, I, 47, I52. Cf. p. 217.

162,3. Laurencín, Documentos, p. 27.

I62,4. Sandoval, II, 583-6; Zapata, Miscelánea, p. 68; Navarrete, Vida, p. 7o. (In the document there presented he is called a son of Pedro Laso. Navarrete calls attention to the error in a note.) Figueroa composed a sonnet on his death, first published in Ramirez Pagán, Floresta de varia poesia, Valencia, I562, f. $4 \mathrm{I} \mathrm{v}^{\circ}$. He is also mentioned by Gerónimo de Urrea in his translations of the

\section{A N D M O N O G R A H S}




\begin{tabular}{|c|c|}
\hline 486 & GARCILASO DE LA VEGA \\
\hline & 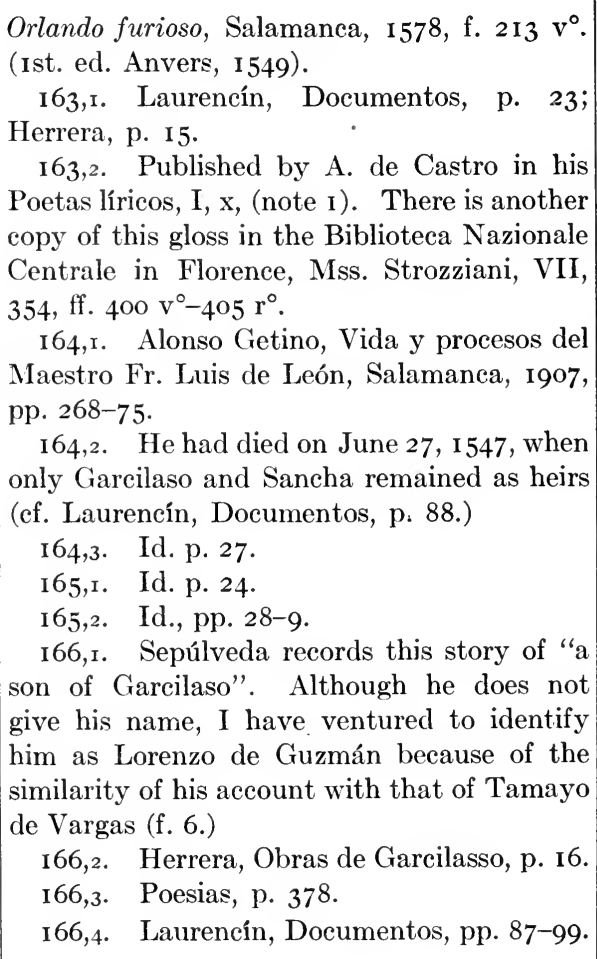 \\
\hline & H I S P A I C N OTES \\
\hline
\end{tabular}




\section{I F E A N W O R K S}

I67,r. Id. pp. I06-7.

167,2. Obras de Garcilasso, p. 266.

167,3. Navarrete. Vida, p. 262.

I68, r. Laurencín, Documentos, pp. 32-3.

I68,2. I am indebted to Sr. Don Juan Moraleda y Esteban of Toledo for information concerning the fate of Garcilaso's remains.

I69, I. El Imparcial (Madrid), is de Agosto de 1900 .

I7 I,r. In B. A. E. XXXVI, 53.

I7 I,2. Miscelánea, pp. 392-3.

I72,r. Id., pp. 297-8. There is another anecdote on p. 393.

I73, I. Obras de Garcilasso, p. I4.

I73,2. The works of G., p. I5I.

173.3. The most widely known is that printed in Carderera y Solano, Iconografía española (Madrid, I $855^{-64}, 2$ vols.) II, $\mathrm{N}^{\circ}$. LXXIII. It is reproduced in Laurencin, Garcilaso y su retrato.

I74,r. Navarrete, Vida, pp. 210-I.

174,2. Laurencín, Garcilaso y su retrato.

174,3. Ein Bildnis des Dichters Garcilaso de la Vega (in Jahrbuch des $k$. preussischen Kunstsammlungen, Berlin, XIV (I893), I779o.) Another article in España Moderna, t. 3IO, I35-I 50 .

\section{A N D M O N O G R A H S}




\begin{tabular}{|c|c|}
\hline 488 & GARCILASO DE LA VEGA \\
\hline & 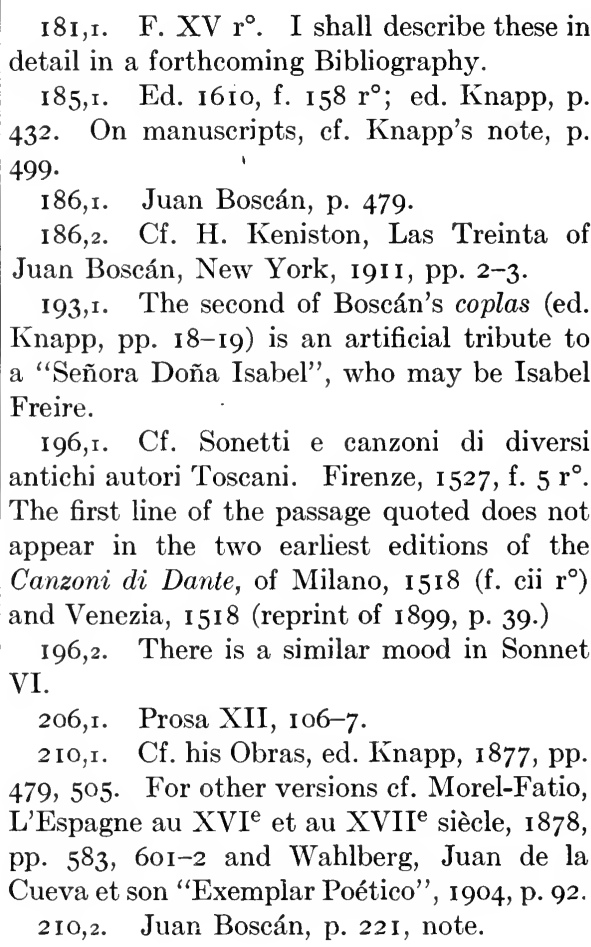 \\
\hline & H I P A N I C NOTES \\
\hline
\end{tabular}




\section{I F E A N D W O R K}

2 I I,I. Ed. Knapp, p. 65.

2i2,r. Ed. Barcelona, I 543, f. $\mathrm{LV} \mathrm{v}^{\circ}$.

2 I 5, I. Cf. p. I2I.

216,r. Cf. Obras de Boscán, p. 522.

216,2. In Romanische Studien, hrsg. von E. Boehmer, IV, 203-4.

2 I7,r. Opere volgari, I723, p. 349. There are numerous translations of this sonnet in Spain during the Golden Age. Different versions may be found in the Cancionero general de I554 (ed. Morel-Fatio), No. CXXIX; Fernando de Acuña, Varias poesías, I 804, p. 204; Espinosa's Flores de poetas ilustres, Parte I, I 896 , p. I 85 (by Gerónimo de Mora); Rey de Artieda, Discursos, epistolas y epigramas de Artemidoro, I605, f. I03; and the manuscript described by Gallardo, Ensayo, I, I06I.

2:7,2. In Boletín de la R. Academia Española, I, 47, I52. Sr. Menéndez Fidal has confirmed me in my belief that these sonnets are not the work of our poet, pointing out that the elder of the two is called "Garcilaso" in the manuscript, and not "Garcilaso de la Vega".

217,3. In a manuscript of the Biblioteca Publica of Evora $\frac{\text { CXIV }}{(2-2)}$ f. I I9 $v^{\circ}$. there is

\section{A N D M O N O G R P H S}




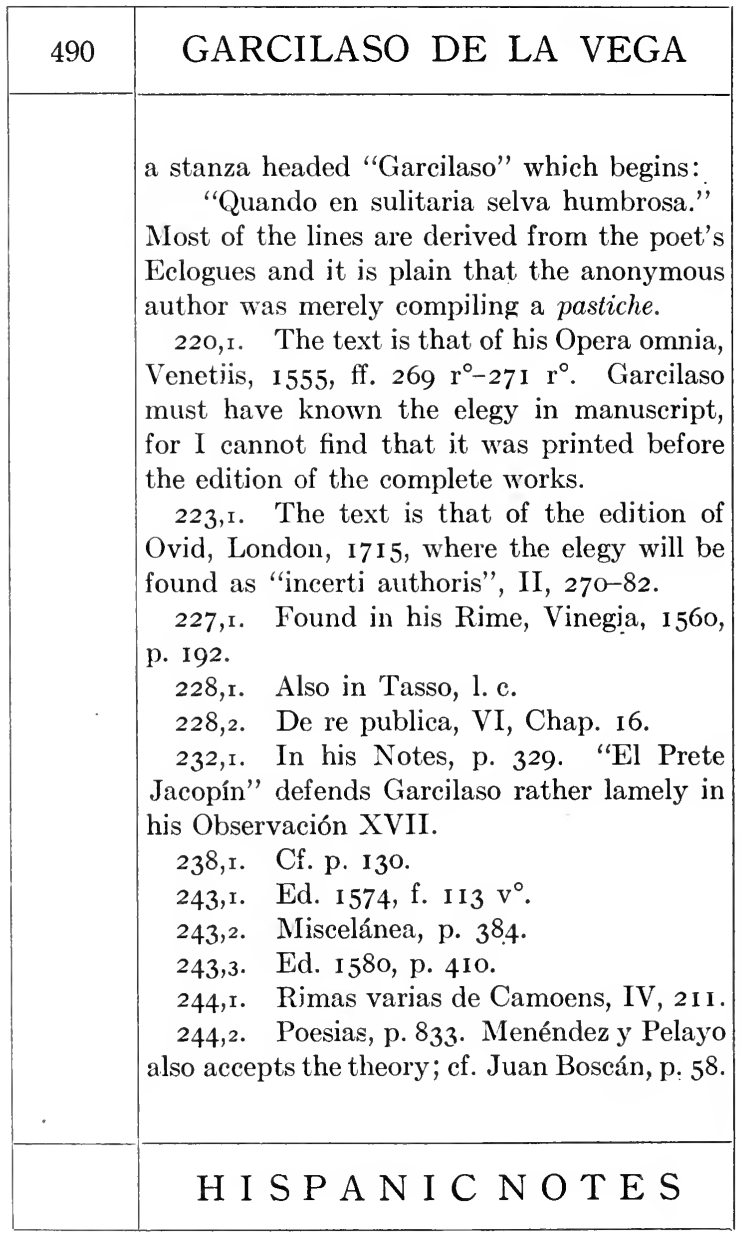




\section{I F E A D W O R K S}

257,r. Cf. Gerónimo de Sosa, Noticia de la gran casa de los marqueses de Villafranca, Napoles, 1676, pp. 78-79.

265 , r. F. II $\mathrm{r}^{\circ}$.

267, I Menéndez y Pelayo makes the suggestion in his Juan Boscán, p. I I2, note.

268, r. Cf. his Vida, p. 165 .

268,2. Juan Boscán, p. II 4 .

270, r. Cf. X. Alonso Cortés, Don Hernando de Acuña, Valladolid, (1913), p. 37. The author tries to explain the possibility of Fernando de Acuña's having already written verses in his note on p. 39. But he places his first amorous poems in the following years (pp. 4I-47).

27 I,I. Varias poesías, I804, p. 2 I4.

272,r. Ed. Anvers, I549, f. [254] $\mathrm{r}^{\circ}$.

273 , I. Ed. Valencia, I 562, ff. $[41] v^{\circ}-[42]$ $r^{\circ}$. For another mention by Gregorio Hernández de Velasco, cf. infra, p. 374.

274, I. Cf. pp. $138-39$.

277 , r. The chief work on Spanish versification are Bello's Ortología y arte métrica, published in his Obras completas, Madrid, I8921905, Vol. IV, and E. Benot's Prosodía castellana i versificación, Madrid, n.d., 3 vols. I have not, however, attempted to follow their

\section{A N D M O N G R A P S}




\begin{tabular}{|c|c|}
\hline 492 & GARCILASO DE LA VEGA \\
\hline & 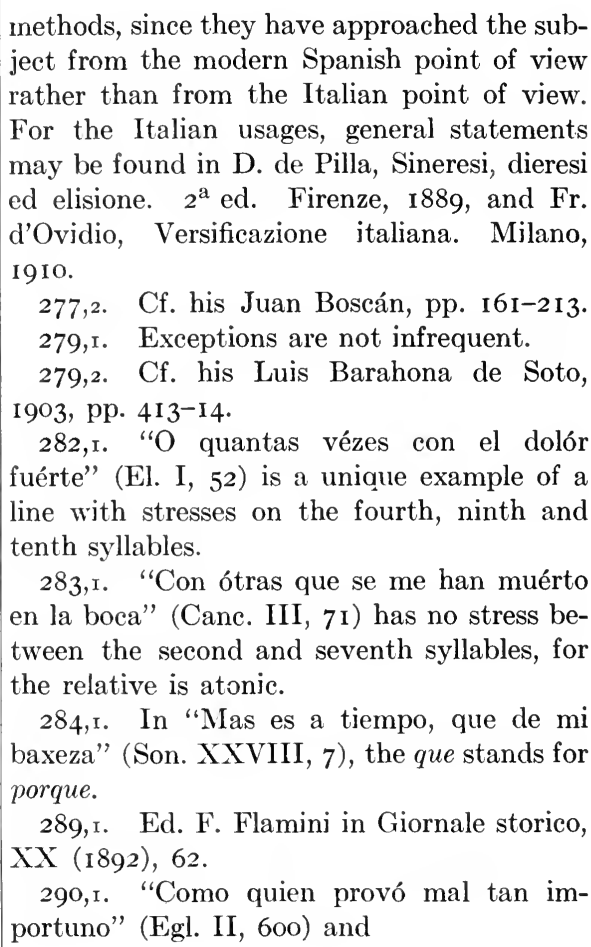 \\
\hline & H I P A N I N OTES \\
\hline
\end{tabular}




\section{I F E A N W O R K S}

"Lo menos de lo que en tu ser cupiere" (Egl. III, 3I)

are hardly verses of arte mayor, but they are certainly not hendecasyllables.

293,r. $A-u$ in seems to show diaeresis in Son. I, I I ; but everywhere else áun is a monosyllable. Cf. Son. V, 4, 6; Son. XIV, I4, etc.

293,2. The ae in Caesar (Egl. II, I52I) is a Latinism for $e$.

297,I. The $h$ is merely a method of expressing the diaeresis. The edition of Barcelona, I543 usually writes: traya, caya, leya, veya, oya, etc.

302,1. There are instances of diaeresis in many of these words or their cognates in Dante and Petrarch: tra-éte (Petr., Son. XLI, I3); tra-éndo (Dante, Purg. X, 56); cre-áre (Petr., Canz. XXIX, ı8); so-áve (Dante, Purg. X, 56; Petr., Son. XV, Io); ru-ina (Petr., Canz. II, 97); po-éta (Petr., Son. CXXXIII, 3); 'sa-étta (Petr., Son. II, 8); ma-éstro (Petr., Trionfo della fama, III, I I I); disle-ále (Petr. Son. LXXVI, 6).

303, I. Viendos is a dissyllable in Egl. II, 5. It is probably due to the influence of other present participles.

\section{A N D M O N O G A P H S}




\begin{tabular}{|c|c|}
\hline 494 & GARCILASO DE LA VEGA \\
\hline & 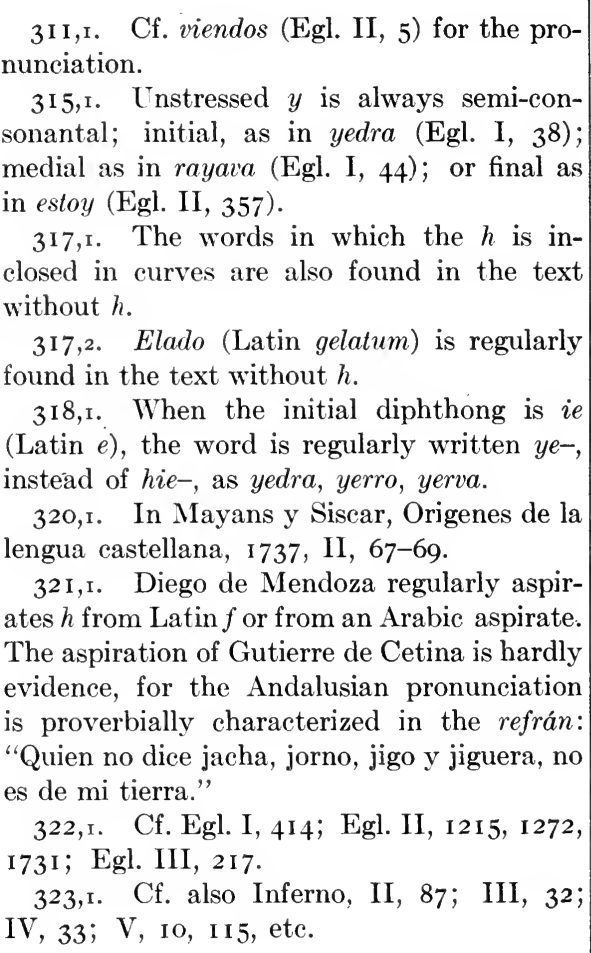 \\
\hline & H I S P A I C N O T E S \\
\hline
\end{tabular}




\section{I F E A N D W O R K S}

323,2. Boscán's practise is by no means as consistent as Menéndez y Pelayo believes (cf. his Juan Boscán, pp. 2I4-I5). Two of the examples which he cites are contrary evidence and at least a dozen examples of elision occur in the Leandro y Hero.

325, I. El. I, 42, as usually printed is an emendation of El Brocense.

325,2. Cf. aquell, Egl. III, 74, ed. of Barcelond, I 543 .

325,3. Cited by Gallardo, Ensayo, IV, I36.

$327, \mathrm{I}$. This reading is hardly grammatical and probably should be "y a la diosa".

327,2. In other similar cases, however, as Egl. II, 986, synaloepha takes place.

328, I. It is improbable that yendo should be read with diaeresis, $y$-éndo.

328,2. Son. XXXI, 9 and Son. XXXVIII, I I belong to the class with stresses on the fourth and seventh syllables. Son. XXXI, 2 and 3 have no stress between the fourth and tenth syllables. 1tali-áno in Son. XXXIII, 6 shows diaeresis of the group $i-a$. The group que aun shows synaloepha in Son. XXXI, I3 and Son. XXXII, го. There is synaloepha in $S \dot{u} \dot{a}$ mo Son. XXXVII, Io) but hiatus in

\section{A N D M O N O G A P H S}




\begin{tabular}{|c|c|}
\hline 496 & GARCILASO DE LA VEGA \\
\hline & 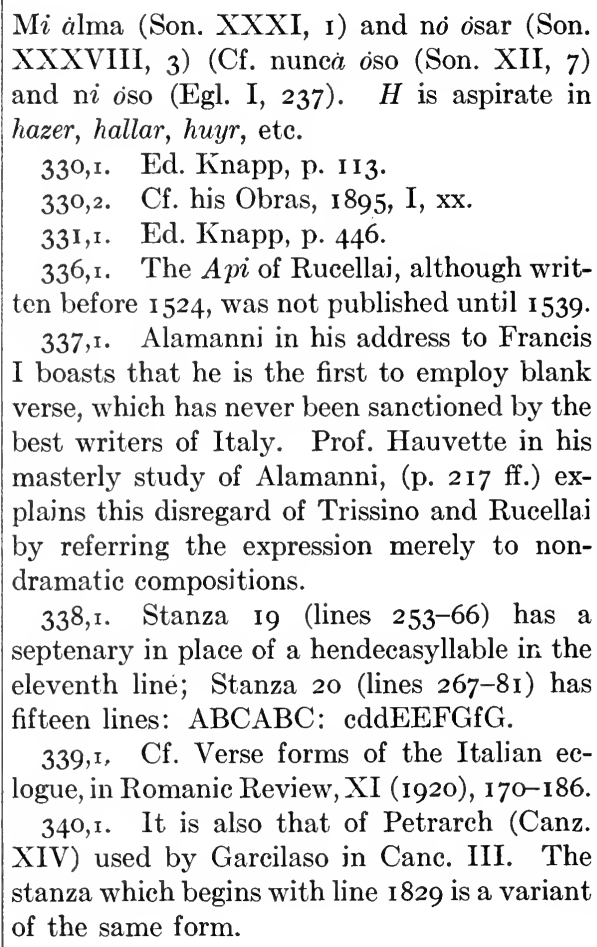 \\
\hline & H I S P A N I N OTES \\
\hline
\end{tabular}




\section{I F E A N D W O R K S}

341,I. Garcilaso's use of inner rhymes for the account of the journey of the Duke of Alba to Ratisbonne may have been suggested by Francesco Galeota's "Cansone dove sono notate tutte le cose de memoria che vide per lo viagio di Franza" in this form (in Giornale storico, XX (1892), 72-78.) It is perhaps worthy of mention that Petrarch uses inner rhymes in his Canz. XI.

341,2. The Tirsi probably derives from the Ninfe fiesolane of Boccaccio.

34I,3. Egloga V, ff. $8 \mathrm{r}^{\circ}-9 \mathrm{v}^{\circ}$.

342,r. Several of Sannazaro's egloghe are wholly in sdruccioli. a fact which may account for their presence here. I am not unaware of the fact that certain of the Sevillan theorists, such as Argote de Molina, Herrera and Juan de la Cueva, regarded words like noticia as esdrújulos and that Cairasco de Figueroa also counted them as such in compositions wholly in this rhyme. But there can be no doubt that to Garcilaso they were llanos, for he at no time uses them consistently together but always with other assuredly llanos verses.

345, I. Examples are Egl. II, 806-8; I I 80I2; 1275-76, etc.

349,1. $F f$ is regular in affeto, deffender,

\section{A N D M O N O G R P H S}




\begin{tabular}{|c|c|}
\hline 498 & GARCILASO DE LA VEGA \\
\hline & $\begin{array}{l}\text { offender, and officio; usual in differente (two } \\
\text { exceptions) and offrecer (three exceptions). } \\
\text { In suffrir the form varies. Dificil (with one } \\
\text { exception) has single f. Juan de Valdés (Dia- } \\
\text { logo, pp. 69-7o) favors ff. } \\
\text { 352,r. Luengo, sendos and tamaño (for tan } \\
\text { grande) are no longer in current usage. } \\
359, \mathrm{r} \text {. Boscán uses the form verés in rhyme } \\
\text { with Veronés (ed. Knapp, p. 445) and Diego } \\
\text { de Mendoza has queréis, hallaréis and pre- } \\
\text { tendéis in rhyme with pies and envés. (ed. } \\
\text { Knapp, p. } 383 \text { ). } \\
365, \mathrm{r} \text {. Senhora Micaëlis de Vasconcellos } \\
\text { in her note on Sá de Miranda's Carta to } \\
\text { Antonio Pereira (Poesias, p. 802) is inclined } \\
\text { to believe that the reference to Boscán and } \\
\text { Garcilaso, found only in the printed editions, } \\
\text { is prior to Garcilaso's death. It should be } \\
\text { noted however, that the phrase "Honra d'Es- } \\
\text { panha que são" is found only in the first edi- } \\
\text { tion (I595) and that in the edition of I6I4 } \\
\text { the reading is "Que honrarão a sua nação". } \\
\text { Moreover there is no necessity for interpret- } \\
\text { ing the phrase in the sense that the poets were } \\
\text { still alive; they remained an "honor to their } \\
\text { nation" after their death. It is interesting } \\
\text { that both in this passage (variants, p. 242) }\end{array}$ \\
\hline & HISPANICNUIES \\
\hline
\end{tabular}




\section{IF E A D W O R K S}

and in Egl. V, 65, Sá de Miranda imitates the phrase of Garcilaso, "Me voy mi passo a passo," (El II, 23).

368 ,r. Obras, II, 107; it was written before the death of Boscán.

368,2. Al lector: f. [b viiij] $\mathrm{r}^{\circ}$. "Y no fuera mucha gloria la de nuestra lengua y su poesia en imitar el verso italiano, si no mejorara tanto en este genero Garcilasso de la Vega, luz muy esclarescida de nuestra nacion; que ya no se contentan sus obras con ganar la victoria y el despojo de la Toscana, sino con lo mejor de lo Latino traen la competencia y no menos con lo muy precioso de Virgilio y Horacio se enrriquescen." Also in Fernán Pérez de Oliva, Obras, Cordova, I 586, f. II $r^{\circ}$.

369 , r. Orlando furioso, traduzido en romance castellano por Jeronymo de Urrea. Anvers, Martin Nucio, I549, f. $230 \mathrm{r}^{\circ}$.

370, . I I have used the reprint in Schottus, Hispaniae illustratae. Francofurti, I603-8, II, 820 .

370,2. Arcadia, traduzida nuevamente en nuestra Castellana lengua Hespañola, en prosa y metro como ella estava en su primera lengua Toscana. (Toledo, Juan de Ayala,

\section{A N D M O N O G A P H S}




\begin{tabular}{|c|c|}
\hline 500 & GARCILASO DE LA VEGA \\
\hline & 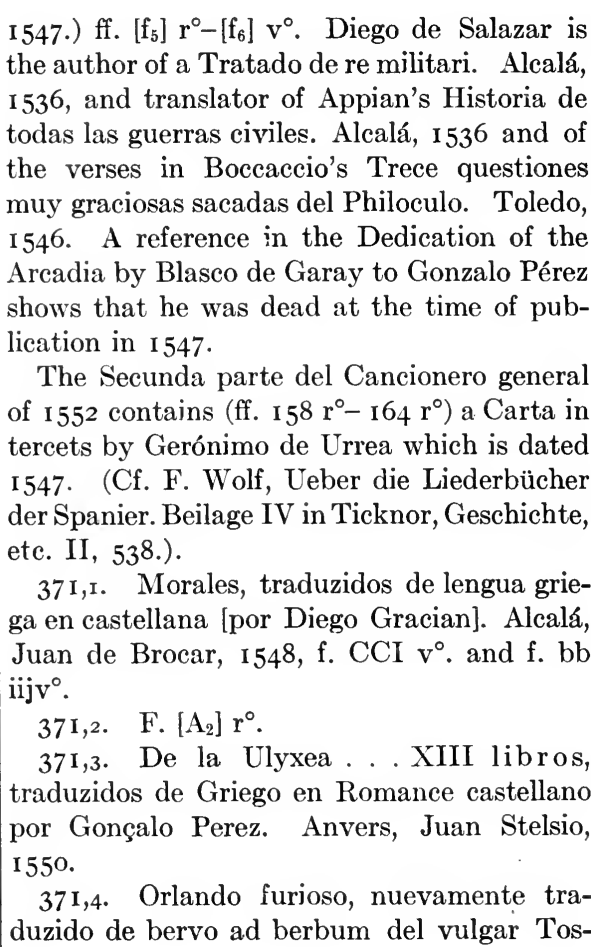 \\
\hline & H I P A N I C N O T E S \\
\hline
\end{tabular}




\section{I F E A N D W O R K S}

cano en el nuestro castellano por Hernando Alcoçer. Toledo, Juan Ferrer, 1550. There are three sonnets among the preliminaries.

37 I,5. Alcalá, Joan de Brocar, I550. Juan Hurtado de Mendoza, was one of the leading figures of the new school. There is an interesting reference to his leadership in the Historia de los amores de Clareo y Florisea (Venecia, Yulito, I552) of Alfonso Núñez de Reinoso, in which the author speaks of the criticism which Mendoza made of his hendecasyllables, as partaking too much of the character of verses of arte mayor. Núnez de Reinoso's work contains sonnets and tercets which reveal precisely the fault which he mentions. Cf. Gallardo, Ensayo, IIl, 984-92.

372 ,r. This is an extension of the common octave used by François Villon and the other writers of the fifteenth and early sixteenth centuries in France.

372,2. Cf. Gallardo, Ensayo, IV, 92 I-26. The editions of 1559 and 1560 are intitled Recopilacion de sonetos y villancicos and contain a number of additional sonnets.

373,r. Toledo, Juan Ferrer, I552. The work contains sonnets by Arias Montano and Juan Hurtado de Mendoza.

\section{A N D M O N O G R P H S}




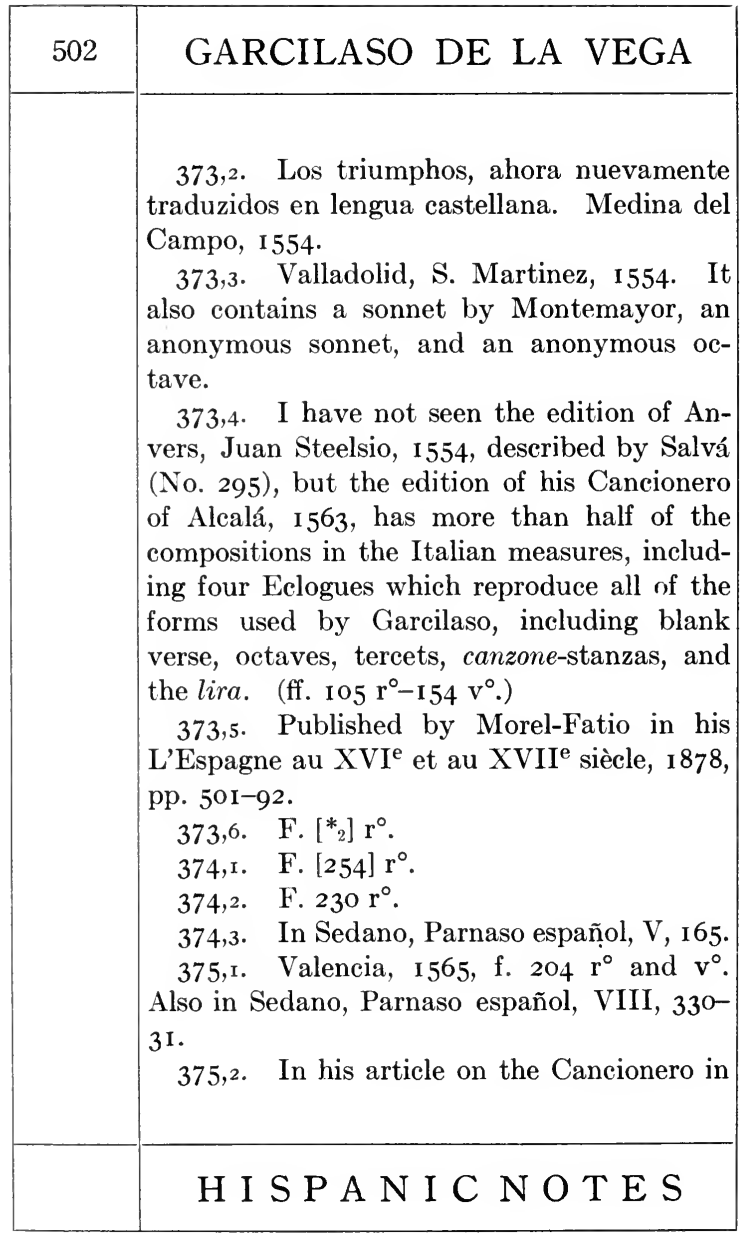




\section{LIFE AND WORKS}

Sitzungsberichte der k. Akad. der Wissenschaften. Phil.-Hist. Classe, X (I853), 195.

376,r. Wolf (op. cit., p. 189) noted that No. CLIII is translated from Petrarch (Son. CII) . . J. P. W. Crawford (in Romanic Review, VII, 332-37) has noted that the following are also from his sonnets: No. CXXXIII, Son. CLXXX; No. CXXXIV, Son. L; No. CXXXVIII, Son. LXIX; No. CXLVI, Son. CLXXXVIII; No. CXLVIII, Son. CCXIV; No. CXLIX, Son. CCCVI; No. CLV, Son. ClXXViII; No. ClVI, Son. CCXX; No. CLXVII, Son. XXXIII; No. CXXIX is a translation of Sannazzaro's Son. XXIII, No. CXXXI of his Son. LXXII, and No. CXL of his Canz. XII. Nos. CLX, CLXIII, and CLXXXI are derived from Ausias March. At least three others are derived from Petrarch, which have not been mentioned; No. CXXVIII is Son. CCXXVI; No. CXXXIX is Son. XLIX and No. CLXIX imitates his Trionfo della morte, II, I ff.

376,2. On Coloma, see Morel-Fatio, op. cit., p. 496.

377 , r. Aside from the use of inner rhyme by Sá de Miranda and Coloma, the earliest examples of which I know are the sonnet with

\section{A N D M O N O G R A P H}




\begin{tabular}{|c|c|}
\hline 504 & GARCILASO DE LA VEGA \\
\hline & 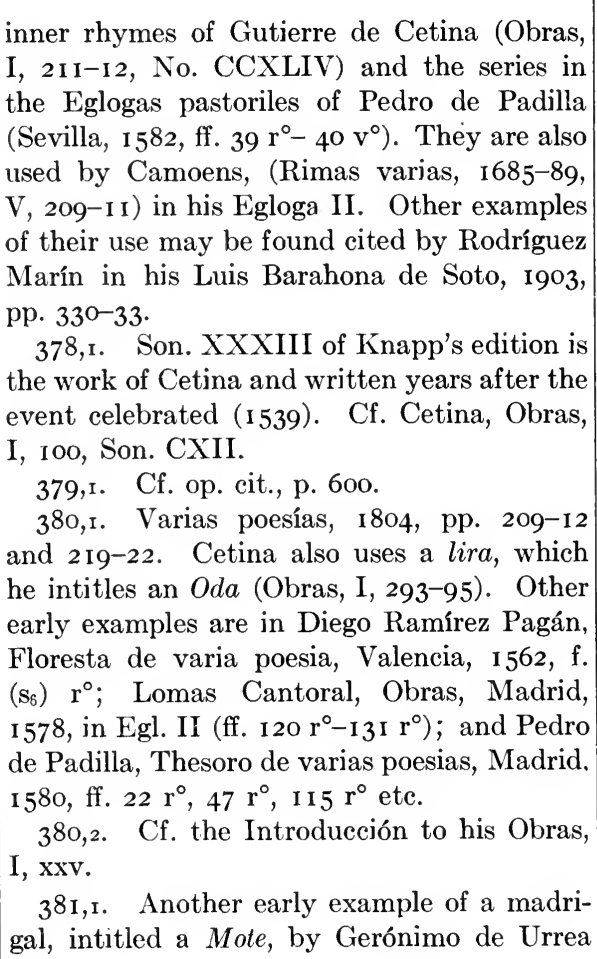 \\
\hline & H I S P A I C N OTES \\
\hline
\end{tabular}




\section{I F A N D W O R K S}

is cited by Gallardo, Ensayo, I, roo3. Cetina's Son. XXXVIII is written in verses of arte mayor. Hazañas y la Rua, (in his introduction, I, lxxii) refers to the sonnets of Juan de Villalpando in the same metre and also to the sonnet in alexandrines by Pedro Espinosa in the Segunda parte de Las flores de poetas ilustres de España, p. 245, No. I70.

381,2. Ed. Knapp, pp. 48-56. Eugenio de Salazar addressed one of his Cartas to Agustín Guedeja; cf. Cartas, Madrid, I866, pp. $8 \mathrm{I}-90$.

383,r. Obras, Madrid, 1792, pp. 243-51. Luis de Haro is also mentioned by Urrea (1. c.) and by Boscán (ed. Knapp, p. 446) and several of his compositions are found in the Cancionero general de 1554 , but curiously enough none of them is in the Italian measure.

385 , . Ed. Granada, I599.

386, r. P. I3.

389, r. Cf. Gallardo, Ensayo, IV, 449-5o.

389,2. Cf. id. IV, 450 .

390,I. F. $\left[\mathrm{A}_{6}\right] \mathrm{v}^{\circ}$.

393, I. Ensayo, III, 332.

393,2. Notes, p. Io9.

394, r. Obras, I 578, f. $218 \mathrm{v}^{\circ}$.

395, r. Obras de Garcilasso, f. $2 \mathrm{r}^{\circ}$.

\section{A N D M O N G R A H S}




\begin{tabular}{|c|c|}
\hline 506 & GARCILASO DE LA VEGA \\
\hline & 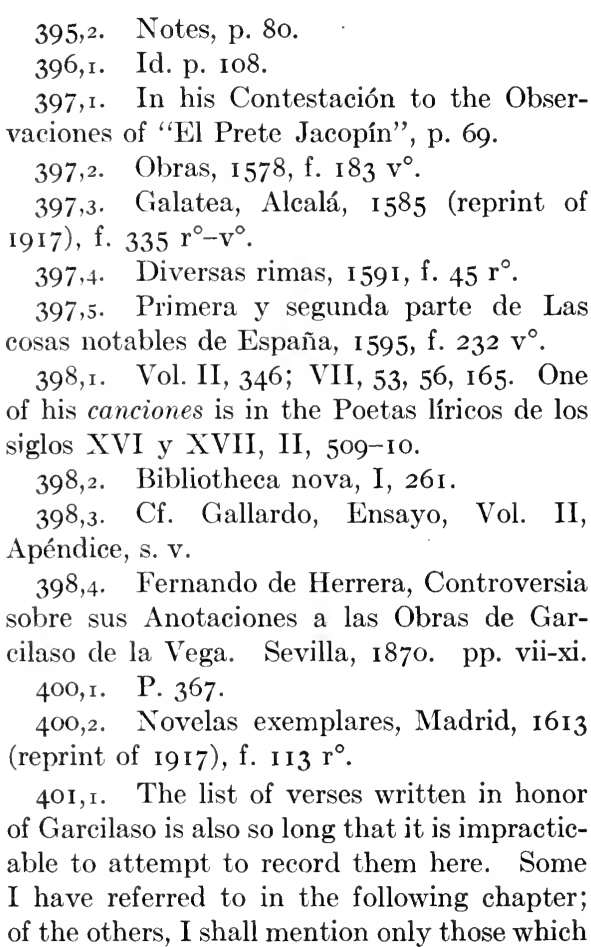 \\
\hline & H I S P A I C NOTES \\
\hline
\end{tabular}




\section{I F E A N D W O R K S}

were printed by Sánchez and Herrera in their respective editions of his works.

403,r. Juan Boscán, pp. 393-94.

403,2. F. $223 \mathrm{v}^{\circ}$.

404,I. F. $25^{8} \mathrm{v}^{\circ}$.

405, r. Ff. $248 \mathrm{r}^{\circ}$ and $249 \mathrm{r}^{\circ}$. Córdova's work is one of the missiles in La derrota de los pedantes, p. 96 .

405,2. Alcalá, I 588, f. [ [ $\left.\boldsymbol{\top}_{2}\right] \mathrm{r}^{\circ}$.

406, I. I have used the edition of Valencia, I 794, p. xix.

407,r. Cited by Gallardo, Ensayo, I, 2 I 4. Lope de Vega refers to Andosilla's work in the Laurel de A polo, (Obras, I776-79, I, I 50-I). Cf. also Álvarez y Baena, Hijos de Madrid. I 789-90, III, I99-203.

409,I. The others are: Francisco de Figueroa, Captain Francisco de Aldana, and Fernando de Herrera.

4 IO, r. Obras, I79I, I, 477 .

410,2. Id., I, 312.

412,r. Obras, I654, ff. $4^{8} \mathrm{v}^{\circ}-49 \mathrm{r}^{\circ}$.

4I3,r. A list will be given in the Bibliography.

413,2. I have used the second edition, Madrid, I 789 , I, I 25.

413,3. Madrid, I797, p. 53.

\section{A N D M O N O G R P H S}




\begin{tabular}{|c|c|}
\hline 508 & GARCILASO DE LA VEGA \\
\hline & 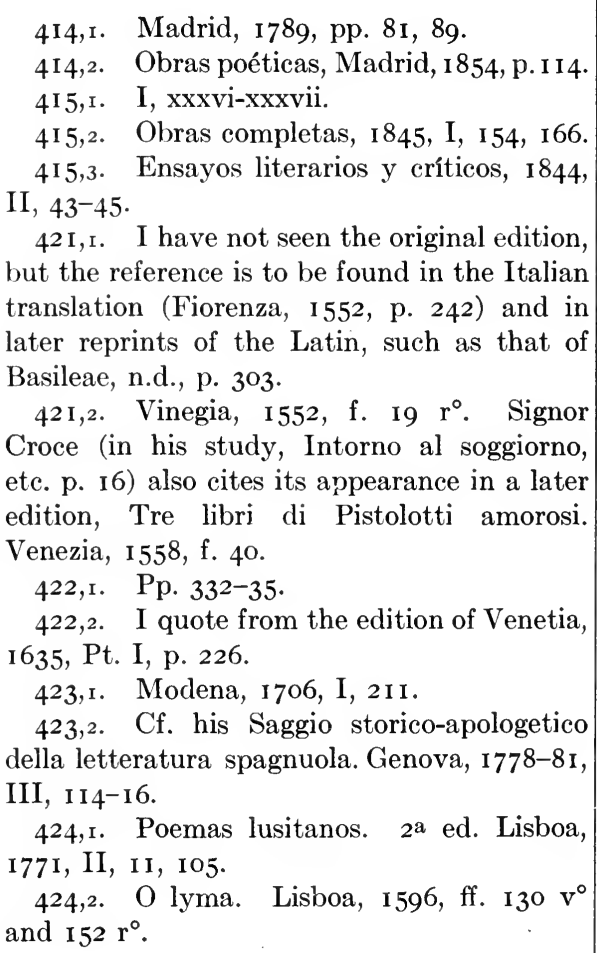 \\
\hline & H I S A N I C NOTES \\
\hline
\end{tabular}




\section{I F E A N D W O R K S}

425, I. Rimas varias, II, 201 , Son. VII.

425,2. Id., III, 133; V, I74 ff.

426, I. P. 315 .

426,2. I have not seen the work. Cf. Fitzmaurice-Kelly, Historia de la literatura española. Madrid, I921, p. 145.

427, r. Les oeuvres poétiques, Lyon, 1603, p. 333 .

$\begin{array}{ll}427,2 . & \text { P. } 395 . \\ 427,3 . & \text { P. I I } 4 .\end{array}$

430, I. On these early mentions, cf. J. G. Underhill, Spanish literature in the England of the Tudors. New York, 1899, pp. 240-42, $270-73$.

431, I. Some account of the lives and writings of Lope Felix de Vega Carpio and Guillen de Castro. London, I817, I, 2-3, 25-26.

433, I. It is the edition of Madrid, Repullés, n.d. now in the Ticknor Collection in the Boston Public Library.

\section{A N D M O N O G A P H S}





I

1350

inting

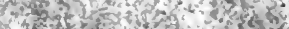

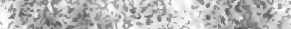

Fithents

Hen 1 .

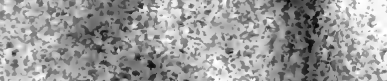

mint

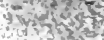

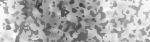

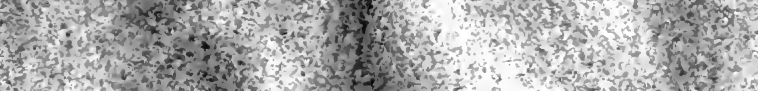

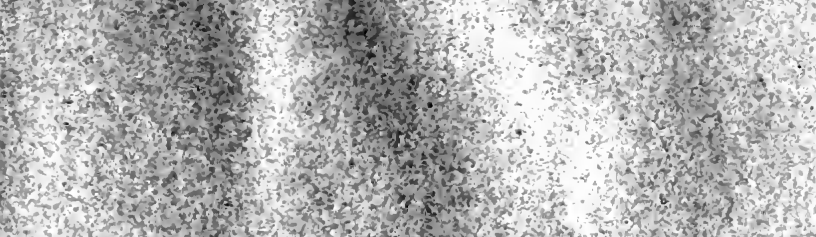

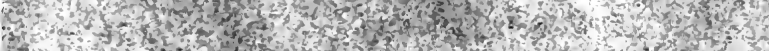

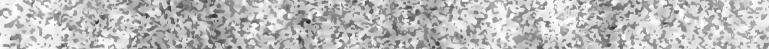

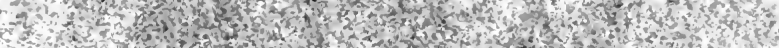

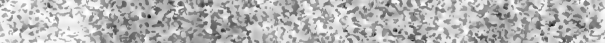

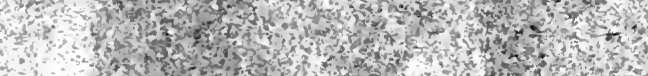

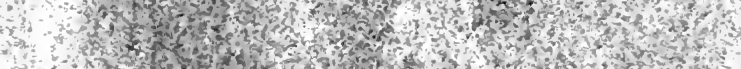

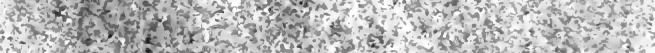
3. 3 (9)

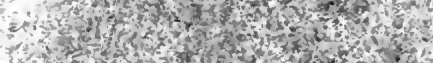

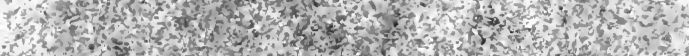

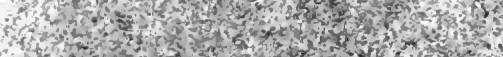

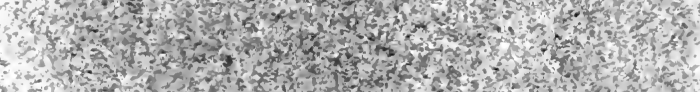

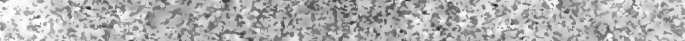

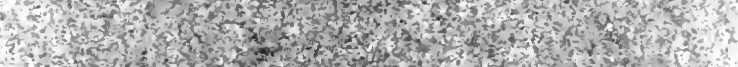

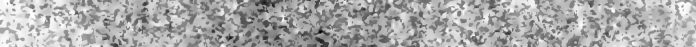

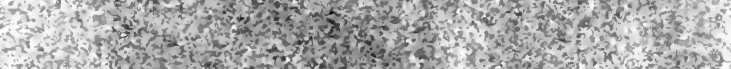

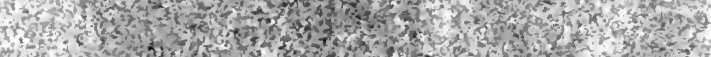

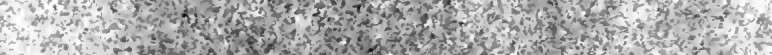

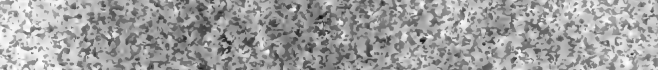

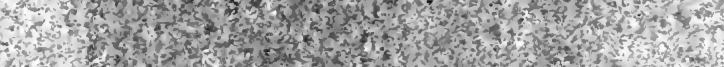

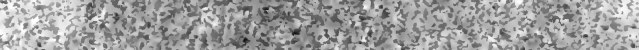
is 2
2
2

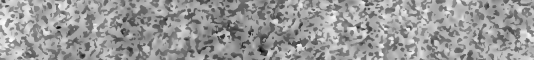

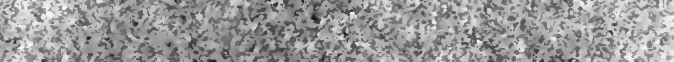

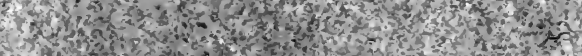
2xim

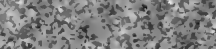

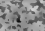

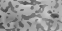

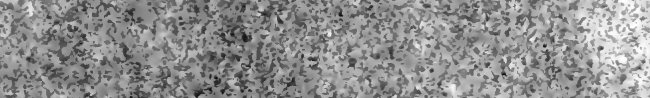


$\because \because$ NO DESE IRRAR " TTF" TORR

firistis

4
4

4

$(1, x+4)$

(y,

w 


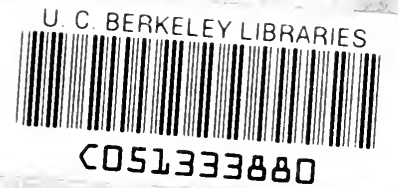

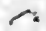
C0513333880 


\section{Hopenoth

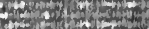

2.t.

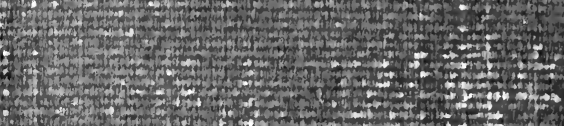

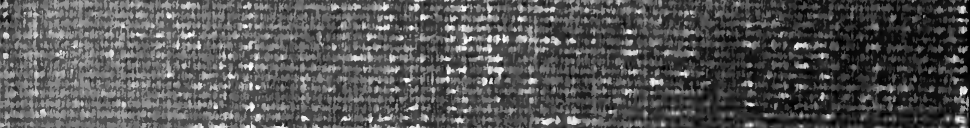

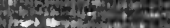

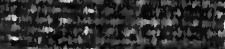

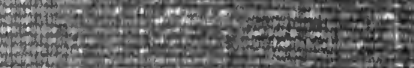

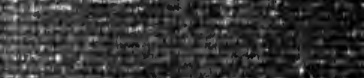

